IPIBASIE II

IFIEASIBILIITY STUDY

PPREIPABIDID IBY

IPONCA INDUSTRIAL CORIPORATION

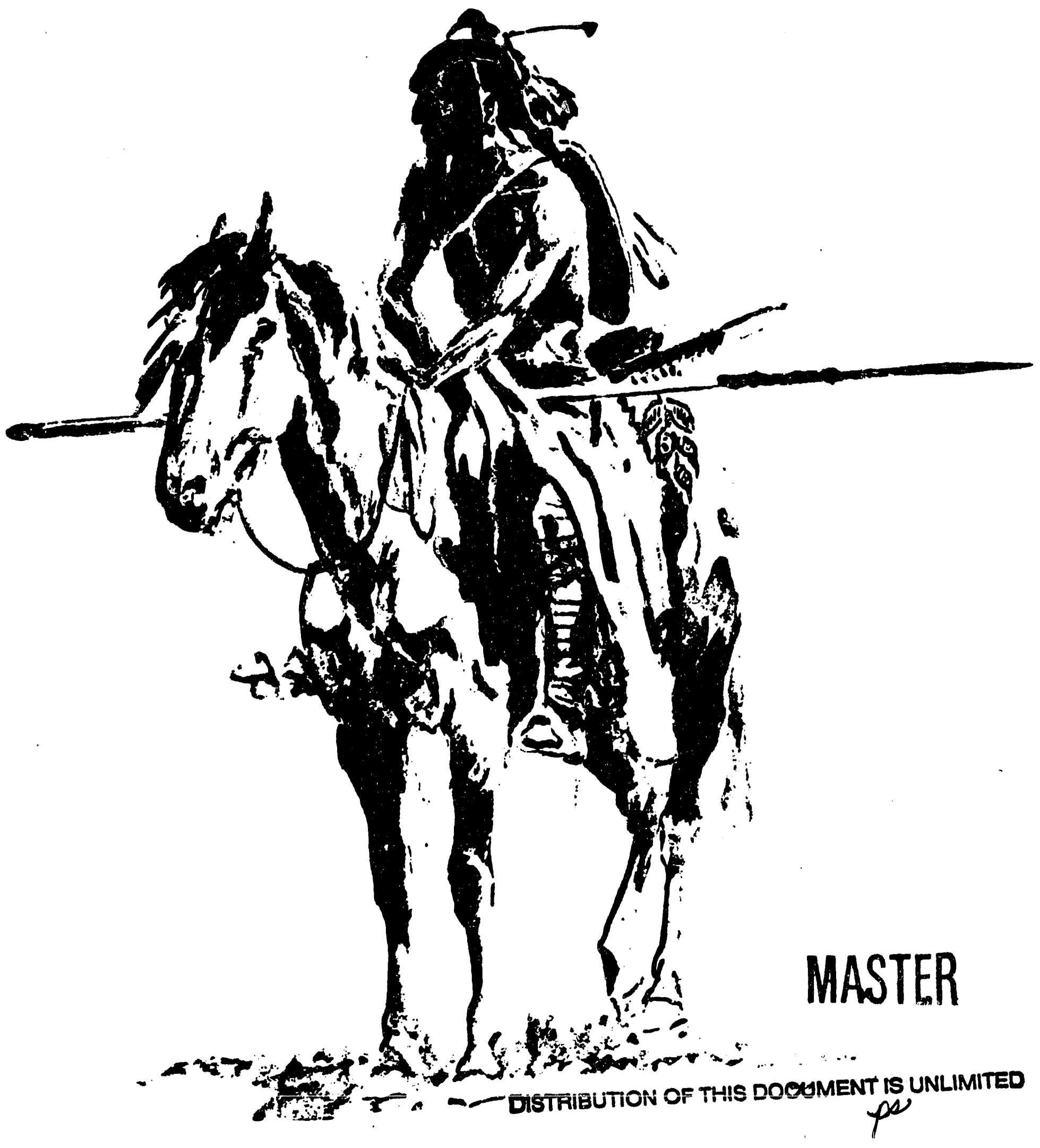




\section{FEASIBILITY STUDY}

\section{ASSESS THE FEASIBILITY OF SITING A MONITORED RETRIEVABLE STORAGE FACILITY PHASE I}

submitted by

John W. King

of

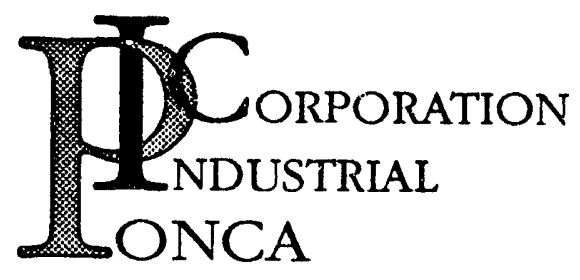

P.O. Box 154082

Irving, Texas 75015

(214) 579-1144

\section{Agent/Negotiator}

for

\section{Ponca Tribe of Oklahoma}
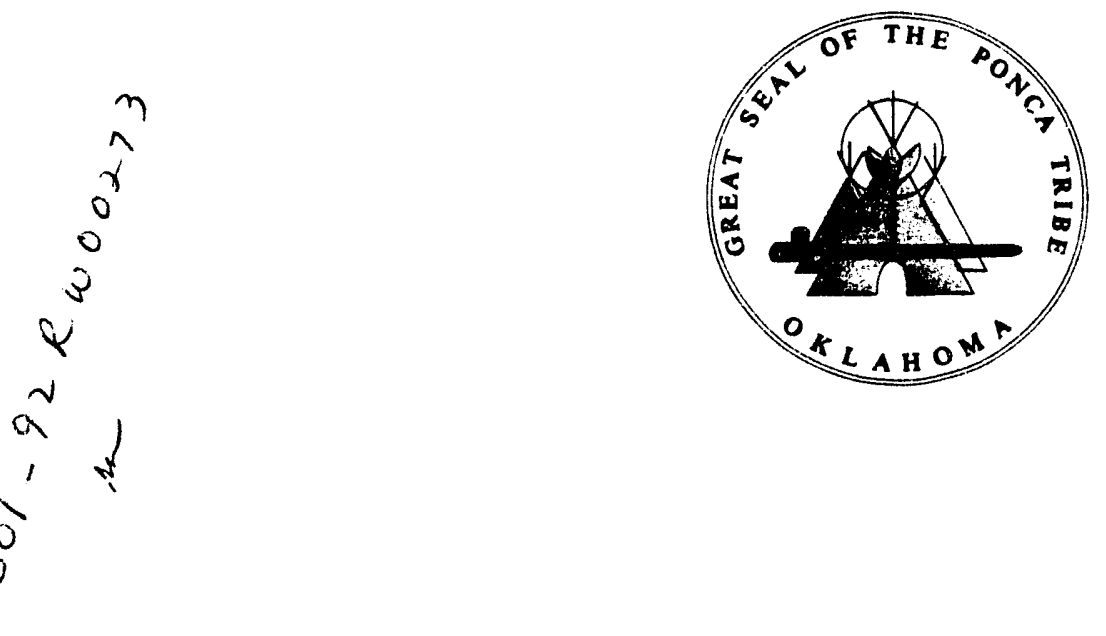


\section{FEASIBILITY STUDY}

\section{ASSESS THE FEASIBILITY OF SITING \\ A MONITORED RETRIEVABLE STORAGE FACILITY}

\section{PHASE I}

1. Understanding the waste management system and a Monitored Retrievable Storage Facility.

2. Determine whether the applicant has real interest in pursuing the Feasibility Assessment Process.

\section{DISCLAIMER}

This report was prepared as an account of work sponsored by an agency of the United States Government. Neither the United States Government nor any agency thereof, nor any of their employees, makes any warranty, express or implied, or assumes any legal liability or responsibility for the accuracy, completeness, or usefulness of any information, apparatus, product, or process disclosed, or represents that its use would not infringe privately owned rights. Reference herein to any specific commercial product, process, or service by trade name, trademark, manufacturer, or otherwise does not necessarily constitute or imply its endorsement, recommendation, or favoring by the United States Government or any agency thereof. The views and opinions of authors expressed herein do not necessarily state or reflect those of the United States Government or any agency thereof. 


\section{CONSULTANTS WHO PARTICIPATED IN FEASIBILITY STUDY, PHASE I--ASSESS THE FEASIBILITY OF SITING A MONITORED RETRIEVAPLE STORAGE FACILITY}

John W. King

Member, Ponca Tribe of Okahoma

Agent/Negotiator, Ponca Tribe of Oklahoma Chairman of the Board, Ponca Industrial Corp.

Applicant/Recipient, Phase I Grant

\section{Andrew Snake}

Member, Ponca Tribe of Oklahoma

Liason; Ponca Tribal Business Committee

Manager, Public Informatien

\section{Doncellia Sakiestewa}

Member, Ponca Tribe of Oklahoma

Assistant Liason, Ponca Tribe

Fred W. Gabourri, Sr. Member, Canadian Seneca Tribe Legal Counsel
Rosemary Templin

Governmental Consultant

Charles Kavanaugh

Administrative, Business, Graphics Consultant

Philip R. Smith

Administrative, Business, Financial Consultant Writer/Editor

\section{Benita Pierce}

Administrator/Archivist

John W. Poston, Sr., PhD

Department Head, Nuclear Engineering, Texas A\&M University

Technical Consultant

Wilson W. Pitt, Jr., PhD

Ass't. Department Head, Nuclear Engineering

Texas A\&M University

Technical Consultant 


\section{FEASIBILITY STUDY \\ ASSESS THE FEASIBILITY OF SITING A \\ MONITORED RETRIEVABLE STORAGE FACILITY}

PHASE I

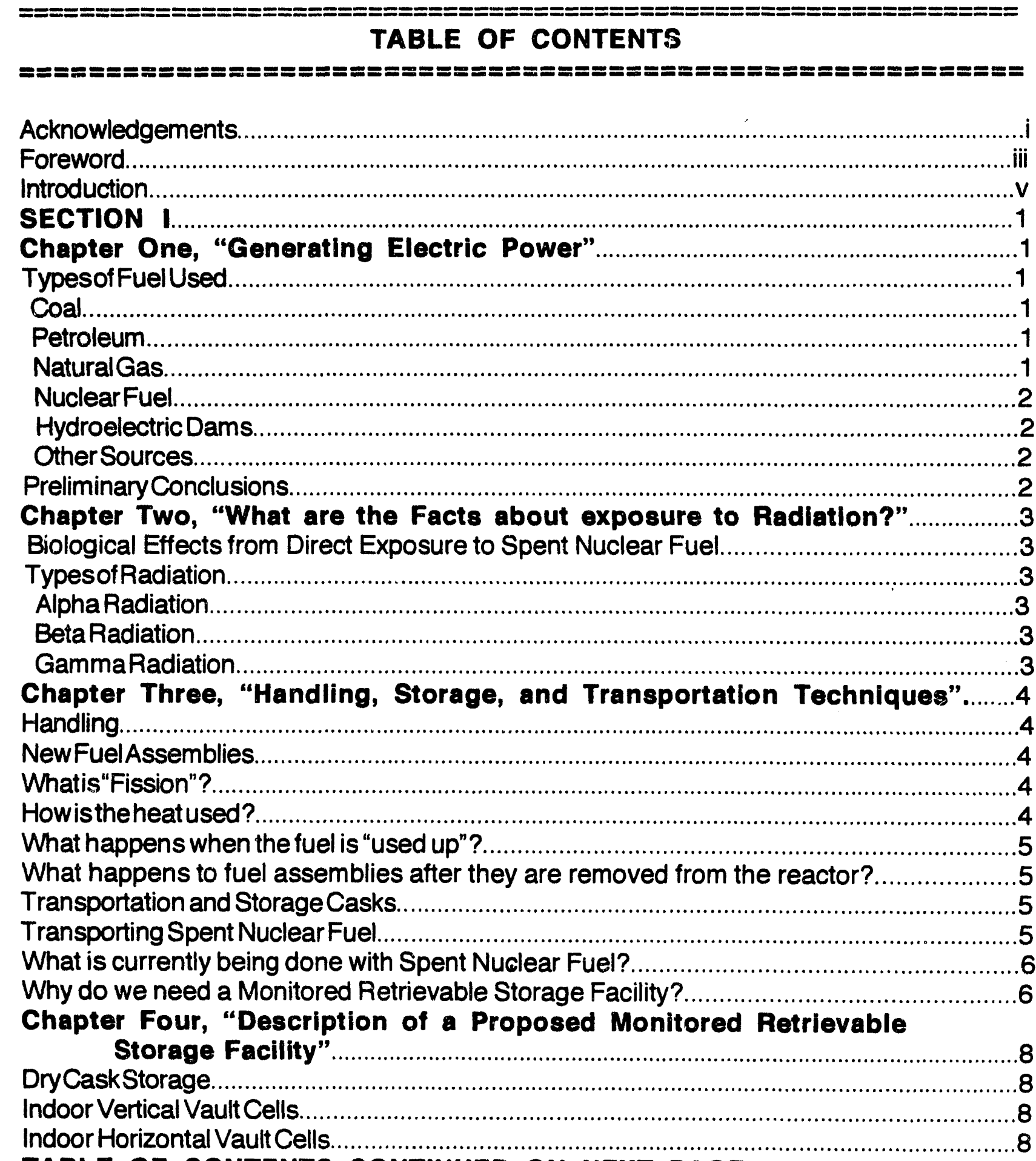

TABLE OF CONTENTS CONTINUED ON NEXT PAGE 
TABLE OF CONTENTS, CONTINUED

Chapter Five, "Benefits to be Received by Host Jurisdiction..........................

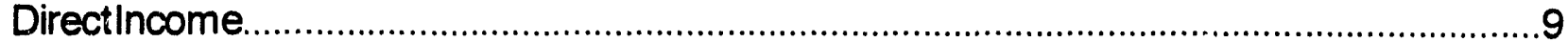

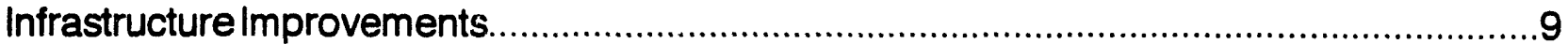

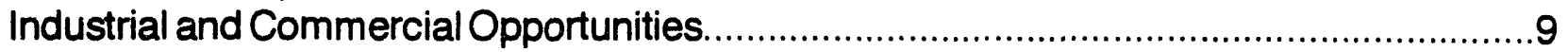

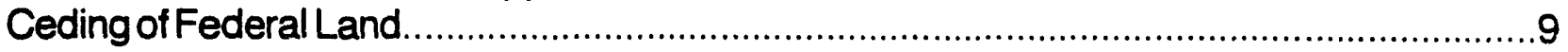

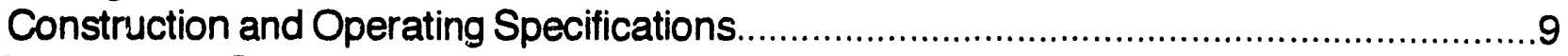

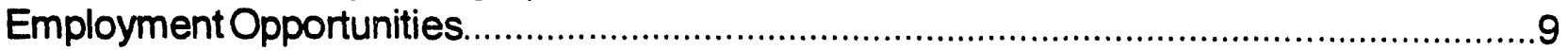

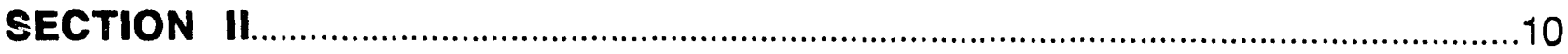

\section{Appendix I, Illustrations}

A Possible Design of a Monitored Retrievable Storage Facility

U.S. Commercial Nuclear Power Reactor Sites

NRC Agreement States

1990 Net Nuclear Electric Power as Percent of World Nuclear and Total Domestic

Electricity Generation/Percent of Total Domestic Net Electricity Generation

1990 Net Electricity Generated in Each State by Nuclear Power

1990 U.S. Electric Capability and Net Generation by Energy Source

DOE series of articles \& illustrations on Radiation, Site Requirements, MRS,

Storage of Spent Fuel, Civilian Radioactive Waste System,

Transportation of Spent Fuel 6 pages, both sides

Monitored Retrievable Storage Facility, 13 pages

Dry Cask Storage Fact Sheet

Visitors Brochure, Virginia Power \& Light, Surrey Virginia

Civ. Radio active Waste Management System Management \& Operating Team

Department of Energy Presentation, 45 pages

Appendix II, Letters

Fred W. Gabourie, Sr.

W.W. Pitt, Jr; J.W. Poston, Sr.

W.W. Pitt, Jr; J.W. Poston, Sr.

David H. Leroy

Appendix III, Interviews (Meetings, Plant Tours) 



\section{ACKNOWLEDGEMENTS}

\section{PONCA LEADERSHIP}

We would like to express our sincere appreciation to the Members of the Ponca Business Committee during the more than two years we have worked upon this Project. These leaders have shown consistent support for our efforts and have contributed their wise advice and solid cooperation. Our special thanks are offered to Mr. Kinsel Lieb, 1991 Committee Chairman and to the Members of that Committee, who first recognized the potential value that the Project could bring to the Tribe and the virtues of appointing John King of Ponca Industrial Corporation to perform the Feasiblity Studies. Mr. Leonard Biggoose, Chairman of the 1992 Business Committee demonstrated his dedication to the welfare of the Tribe by asking "Why?"; after he became satisfied that we were sincere in our efforts to benefit the Tribe, we received his support and are grateful. Ms. Genevieve Pollak, Current Chairperson of the Ponca Business Committee has shown a great deal of fairness in her reviews of our work, always considering the welfare of future generations of Poncas. In addition to Ms. Pollak, we wish to thank the members of the current Business Committee: Mr. Bronson Roughface, Sr., Mr.Douglas G. Rhodd, Mr. Kinsel V. Lieb, Ms. Marie Pappan, and Mr. Bennett Arkeketa. Nembers of past Committees and Chairpersons who have been supportive also deserve our thanks, and they are: Mr. Delbert A. Cole, Ms. Chloe Eagle Rhoads, Mr. George White Eagle, Mr. Steve Pensoneau, Mr. Pinkey Rhodd, Ms. Cynthia Stoner, Mr. Dwight Buffalohead, and Mr. Oliver Littlecook.

\section{U.S. NUCLEAR WASTE NEGOTIATOR'S OFFICE}

From the very beginning, we have had constructive and helpful dialogue from the Hon. David H. Leroy, U.S. Nuclear Waste Negotiator, appointed by President George Bush. His Executive Assistant, Mr. Charles Lempesis has provided cordial and helpful assitstance in our efforts, and Mr. Henry Ebert has given us tireless support, valuable advice and constant encouragement during the entire process. Our heartfelt thanks are given to these highly dedicated Public Servants.

\section{U.S. DEPARTMENT OF ENERGY}

We thank all of the DOE Officials who assisted us through the maze of application procedures and actually accomplishing our Study. These helpful individuals were: Mr. Alan Benson, Mr. Ronald Milner, Mr. Victor Trebules, Mr. Jeffrey Williams, and Ms. Gracie Narcho. In addition, three professionals from Duke Engineering \& Services, Mr. Edwin C. Cheatham, Mr. James S. Medford, P.E., and Ms. Rebecca A. Apter were constantly at our side, helping us with our every request and answering countless questions during our visits to DOE and the $\mathrm{Va}$. Power \& Light Nuclear Facility at Surrey, VA. 


\section{ACKNOWLEDGEMENTS, Continued}

\section{VIRGINIA POWER \& LIGHT}

During our tour of Virginia Power \& Light's Nuclear Power Plant at Surrey, Virginia, Mr. Brian Wakeman, Staff Engineer, devoted his whole day to hosting our visit. He and several staff members were on hand to explain every detail of the Plant and of their Spent Fuel Storage Facility. His enthusiastic presentations and patient answers to our countless questions contributed greatly to our understanding of nuclear power and the handling of spent nuclear fuel. We also owe a debt of gratitude to Ms. Carol Elmore for aiding in our tour and making our visit that much more enjoyable.

\section{PUBLIC SERVICE COMPANY OF COLORADO}

In order to complete our Study on time, it was imperative for us to request a visit to Public Service's Nuclear Facility on very short notice. Mr. Steven S. Sherrow served as our gracious host and conducted our tour of the facility. We thank him for his thorough and candid answers to our many questions. 


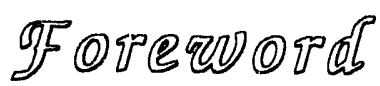

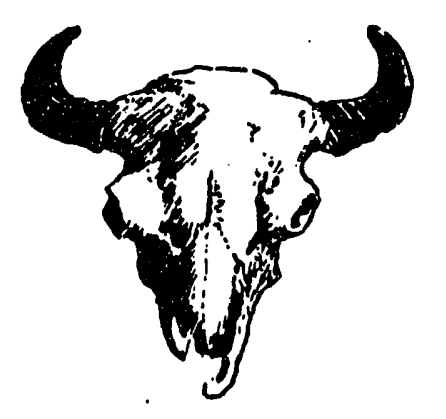

ब5
0
0
0
00
05
06

C. M. RUSSELL

oREAT RALLS, MONTANa

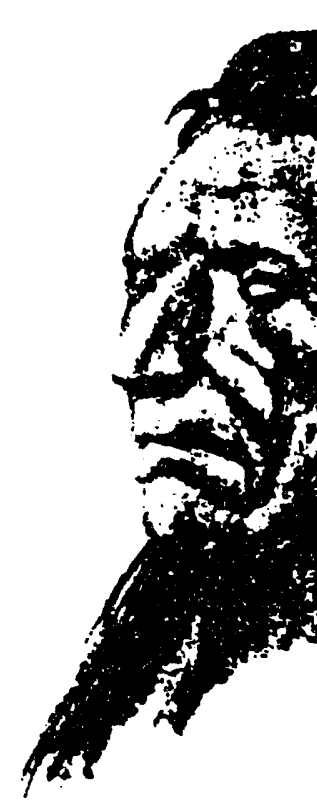

$\begin{array}{ll}\operatorname{Sin} x & 30 \\ 1914\end{array}$

Fruend gfor

C) heve ago

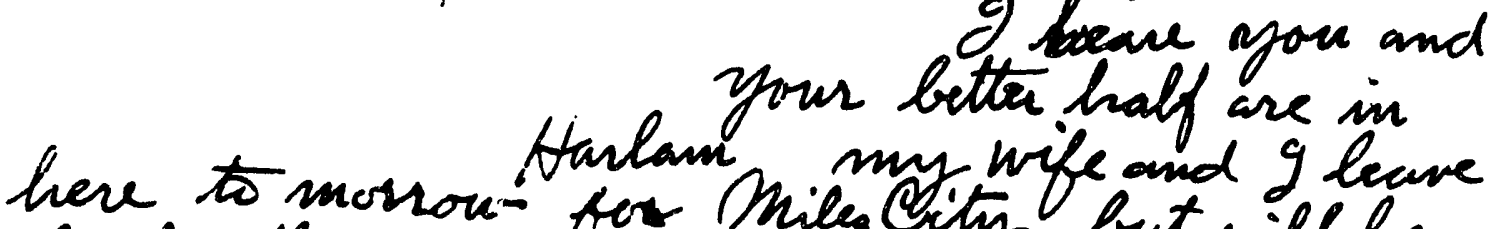
back the 6 of thely and gibs but will be

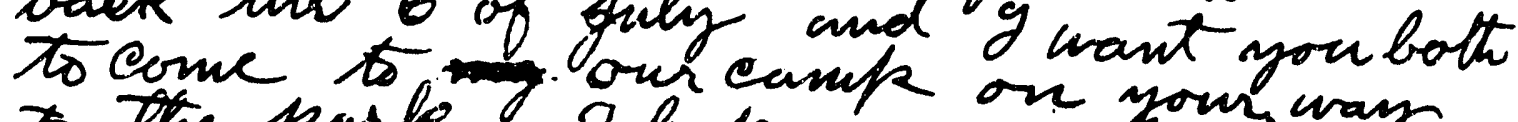
to the patk 8 hope you are ham way

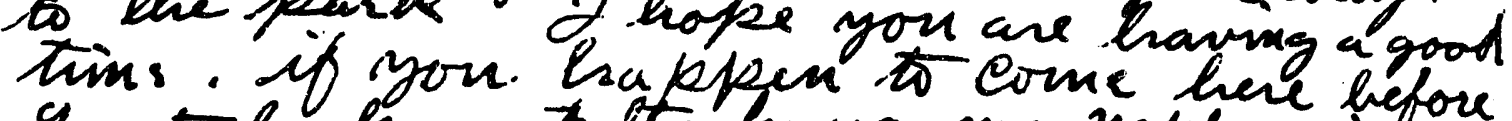
y get besk go to the house my naphew is ofore

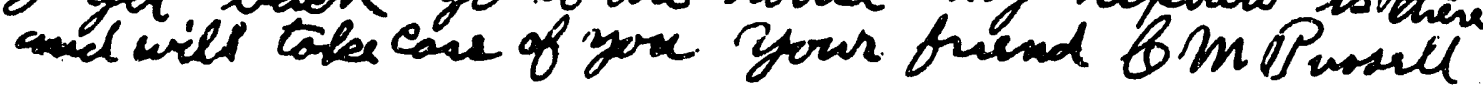




\section{FOREWORD}

Not too many weeks ago, we bade farewell to 1992--the 500th anniversary of Columbus' discovery of the western hemisphere. There were parties, fireworks, and re-enactments of the 1492 arrival of the small flotilla. There were television "specials" on the subject and special excursion rates to Spain--even the Olympics were held there and a special commemoration of the event was made. The atmosphere was festive and the celebrations joyful.....

.....but nowhere in all of these newsworthy events did any of the media voices pause to reflect upon the effects that "civilizing" the new world and the resulting "progress" has had upon the environment of this continent....

For more than twenty five thousand years before the invasion of European immigrants, the beginning marked by Columbus' discovery, Mother Earth was unmolested by the plow, the rivers were unpolluted, the air was sweet and clear ..... and the indigenous peoples of North America, the "two-leggeds", lived in harmony with and respected their brothercreatures--the fourleggeds, the flying, swimming, and crawling creatures--in the vast woodlands, the majestic mouritains, on the seashores, and in the expansive plains of this continent. The Red Man accepted the gifts of Mother Earth, but took only what he needed to live and left the rest undisturbed.

Now, after only 500 years of "civilization", our Mother Earth has been defiled by chemicals and concrete, the waters are filthy and have "dead zones" in which nothing may live, much of our woodlands have been destroyed, many of our brother-creatures are extinct..... and in this "march of progress", even the indigenous peoples who inhabited North America since before recorded history without destroying nature's gifts, were slaughtered by the weapons, diseases, cruelty, and greed of the land-hungry invaders who were welcomed by the indigenous people as brothers.....

.....but something valuable has survived this current five hundred years of destruction.....the conviction of the Red Man that two-leggeds were meant by the Creator of us all to live in harmony with Mother Earth and her bountiful gifts.....

The Poncas have a rich tradition of living respectfully with and in harmony with Mother Earth and with their fellow creatures who live here.....even with the explorers, the trappers, the traders, the pilgrims, the settlers, and the soldiers who came from the East.

Before removal from their ancestral home near the confluence of the Niobrara and Missouri Rivers in Nebraska ("Nebraska" is a Ponca word), the Poncas were a prosperous tribe and were widely known as expert farmers, horse breeders, and buffalo hunters. Through some bureaucratic blunder, the Tribe was accused of participating in the Custer defeat at Little Big Horn--the facts were;

1. The Poncas never engaged in warfare with the United States.

2. In 1804, the Poncas welcomed members of the Lewis \& Clark Expedition, fed them, and gave them shelter. In 


\section{FOREWORD}

return, the Tribe was decimated by smallpox brought by members of the Expedition. At that time, the Tribe numbered more than 2,000 ; by 1877 , due to the epidemic, there were fewer than 600 left when the Army forcemarched the Tribe to Oklahoma Territory --during the march, more than 150 additional Poncas died from malaria, starvation, and exposure.

3. When the Mormons were driven from their homes in the East, the Poncas saved them from starvation and exposure; if it had not been for the Tribe, the Mormons may have never found their "Promised Land" in Utah. Today, near the Niobrara River in Nebraska, stands a monument erected by the Mormons which pays tribute to "a friendly band of Indians".

4. When the Army was driving the Poncas to Oklahoma Territory, a violent storm arose as they were crossing the Platte River; several Cavalrymen were swept into the water--and were rescued by Poncas--even though the Army had just confiscated their belongings and shot their horse herd.

5. The Poncas, like the settlers, frequently had to defend themselves against raids by the Sioux and Cheyenne (who were the warring Tribes at Little Big Horn). Yet, during the treaty process, the land which belonged to the Poncas before removal was ceded by the Federal Government to the Oglalla Sioux, the Tribe of Crazy Horse and Red Cloud. A tragic paradox, considering that the reason for Ponca removal was the false accusation of having participated in the Custer defeat at Little Big Horn.
Even through these unedeserved tragedies and needless hardships, the Poncas remained firm in their convictions of respect for their fellow two-leggeds from the East, their respect for Mother Earth, and for the bountiful gifts of our Creator.

The ancient meaning of the word "Ponca" is translated as "Crown of the People", or "Leaders of the People"; this meaning is regarded as a responsibility and has been recognized for many centuries in the Indian World.....even today, many other tribes honor the Poncas by singing our songs, dancing our dances, and wearing the Ponca "Roach" headdress, made of porcupine quills.

Throughout our history, we have proven the strength of our convictions under conditions which have exterminated other cultures of mankind, and yet we continue to hold as sacred our respect for Mother Earth and all of our Creator's gifts, our respect for fellow humans and brothercreatures, and our role as "Crown of the People".

It is now again time for the Poncas to assume an expanded leadership role, not only in the Indian World, but nationally and internationally, in the struggle to preserve Mother Earth and her environment.....to lead by example.....to share our respect for Mother Earth with the rest of the world.....to assure future generations of a clean and safe world to live in.....and to provide the means for an effective solution to a very serious environmental concern. 


\section{INTRODUCTION}

In 1982, the U.S. Congress passed the Nuclear Waste Policy Act, and in 1987, passed the Nuclear Waste Policy Amendments Act. These pieces of legislation provided the much needed authority to create a highly-regulated and effective means of disposal for the growing accumulation of spent fuel from nuclear power plants.

One provision of this legislation stipulates that the Federal Government will assume responsibility for and will have an effective means to deal with this material by 1998. An interesting funding provision was created by placing a small surcharge upon the users of electricity produced by nuclear power plants, so that allocations would not have to be made from tax revenues. Administered by the U.S. Department of Energy, this fund is meant to pay for an above-ground temporary Monitored Retrievable Storage Facility and an underground permanent repository for the storage of spent nuclear fuel.

A unique Federal Agency was created, the Office of the United States Nuclear Waste Negotiator. President Bush appointed David $\mathrm{H}$. Leroy to fill the position, and Congress mandated that the Department of Energy support his efforts. An approach was devised which provided for a voluntary process in locating a site, rather than merely deciding upon a location without local agreement. This is one reason for this Feasibility Study to be undertaken.

Much controversy has surrounded the use of nuclear fuel to generate electricity in this country, mainly as a result fear from misunderstanding. This is not to say that spent nuclear fuel is not dangerous--unshielded, it is very dangerous--but the handling and shielding techniques have become so advanced that we are convinced that a Monitored Retrievable Storage Facility would pose no danger to nearby populations or to the environment. Conversely, alternative power plant fuels are more expensive than nuclear fuel and cause damage to human health and to the environment by emitting carcinogens, hydrocarbon particulates, and other chemicals which cause acid rain. Even hydroelectric dams are more expensive and cause damage to waterways and wildlife habitats.

Illustrations appear in Appendix I, in the same order in which their subjects appear in the text.

Dialogue from tours and selected meetings were tape-recorded and transcribed; these transcriptions appear in Appendix III, "Tour Interviews".

When reading this Report, it will be helpful to the reader to keep in mind that there has not been one faiality in this country as a result of an accident with nuclear fuel. 
SECEนํำ II Chapier Ome
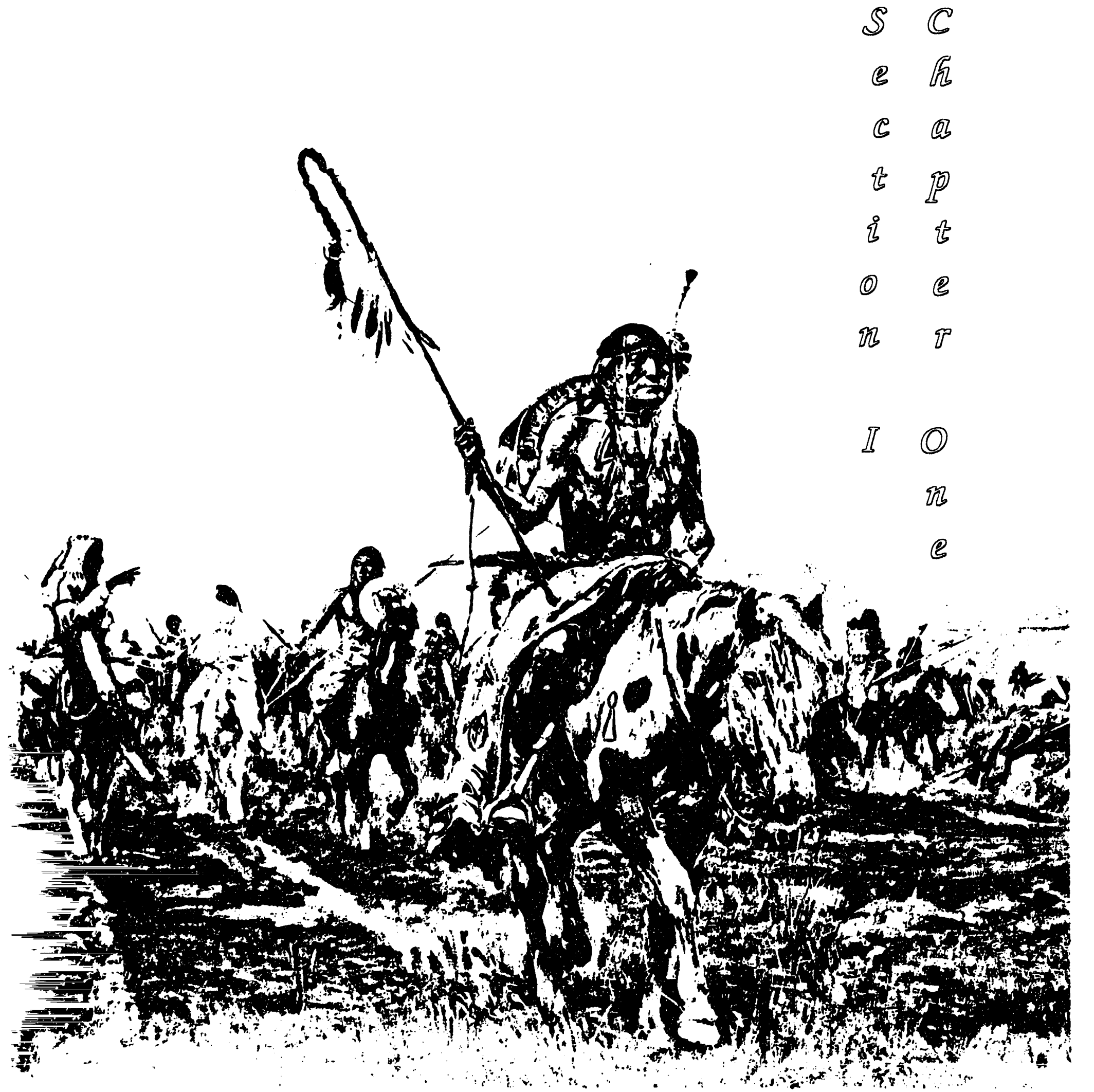


\section{Chapter One \\ GENERATING ELECTRIC POWER}

\section{Editor's Note:}

In order to clearly understand the nuclear waste management system, it is important to first understend why we have nuclear waste.

\section{TYPES OF FUEL USED}

All commercial electricity is generated in approximately the same way; something turns a power plant's turbines, and electricity is generated. Power plants may be classified into two broad categories; those which use nonrenewable resources as fuel, and those which use renewable resources.

In the case of non-renewable resources, fuel is used to heat water into steam with which to turn the turbines; it is the type of fuel which distinguishes one type of power plant from another. It will be most revealing to the reader if each type of fuel is examined and compared with nuclear fuel.....

\section{Coal}

Coal-fired power plants are the most common variety, generating approximately $56 \%$ of this country's electricity. Unfortunately, the use of coal as a fuel results in a myriad of consequences; from coal-fired power plants, chemicals are released into the atmosphere which cause acid rain and global warming. Hydrocarbon particulates, some of them carcinogens, are also released. From mining, this country has not only suffered from adverse environmental destruction, but the miners have suffered from blacklung desease and fatalities from mine cave-ins. The sheer bulk of coal in the quantities required by a power plant, and the resulting transportation costs make coal much more expensive than nuclear fuel.

\section{Petroleum}

Very few power plants in the United States use petroleum as a fuel--approximately $4 \%$. Petroleum's desireability as a fuel is severely diminished as a result of sociological and political conditions. The market demand for petroleum is accellerated by its use as a motor vehicle fuel, which drives up the market price. In addition, the oil-producing countries in the middle-east limit production of crude oil in order to control the prices they receive for it. Like coal, the quantities required to operate a power plant make transportation a costly item, further driving up the cost to produce electricity. A severe environmental drawback associated with the use of petroleum is the risk of spillage, as with the many tanker incidents. In addition, air, water, and soil pollution occur with drastic consequences from the refining and use of petroleum.

\section{Natural Gas}

While natural gas is the least polluting of the fossil fuels, gas-fired power plants account for only $9 \%$ of the electricity prod- 
uced here. The use of gas as a power plant fuel has been made more attractive with the passage of the Natural Gas Policy Act of 1978. It is, however, more expensive than using nuclear fuel.

\section{Nuclear Fuel}

Nuclear fuel is the cleanest of the nonrenewable resource fuels; there is no pollution of the air, water, or earth due to its use. It is also considerably less expen-sive than fossil fuels. Because spent nuclear fuel is solid, rather than liquid or gaseous, it is therefore much easier to contain and manage.

Current and heated controversy exists within scientific and political circles regarding the reprocessing and re-use of nuclear fuel. Great Britain and France reprocess their spent fuel, and Japan contracts with France to reprocess their spent fuel. In the U.S., two plants have been built to reprocess, but were shut down during President Carter's administration; small amounts of Plutonium are produced in the process and this violated his non-proliferation agreement with the Soviet Union. Additionally, the process produces a radioactive slurry from which no use has been found; the slurry is then vitrified (cast into glass "logs") and stored in underground repositories.

If research were to find additional uses for spent nuclear fuel, it then should be considered a resource, rather than waste.

\section{Hydroelectric Dams}

Turbines within hydroelectric power plants, which produce approximately $10 \%$ of the electricity in the U.S., are turned by water released from reservoirs. Usually, a major river is dammed to provide sufficient water to release over the turbines. Although they do not use fuel, severe ecological damage to waterlife, plantlife and landscapes result from their construction and use, including shortages of water to downstream areas. Because of the enormous construction and maintenenance costs, hydroelectric power is also more expensive than nuclear power.

\section{Other Sources}

Geothermal power plants (powered by heat supplied by natural sources within the Earth), solar, and wind generated electricity account for less than $1 \%$ of the power production in this country.

\section{Preliminary Conclusions}

From our investigations, we have thus-far determined during Phase I of this Feasiblity Study, that nuclear fuel is not only the cleanest of the commonly available choices, from an environmental standpoint, but is the least expensive from an overall cost point of view. This conclusion is supported by the fact that the technologically advanced European and Asian countries rely upon nuclear fuel to a much higher degree than we in the U.S. do. 
Section II

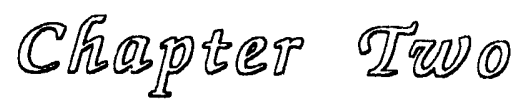

S C

e 胥

(c)

if

i if

P

(1) 8

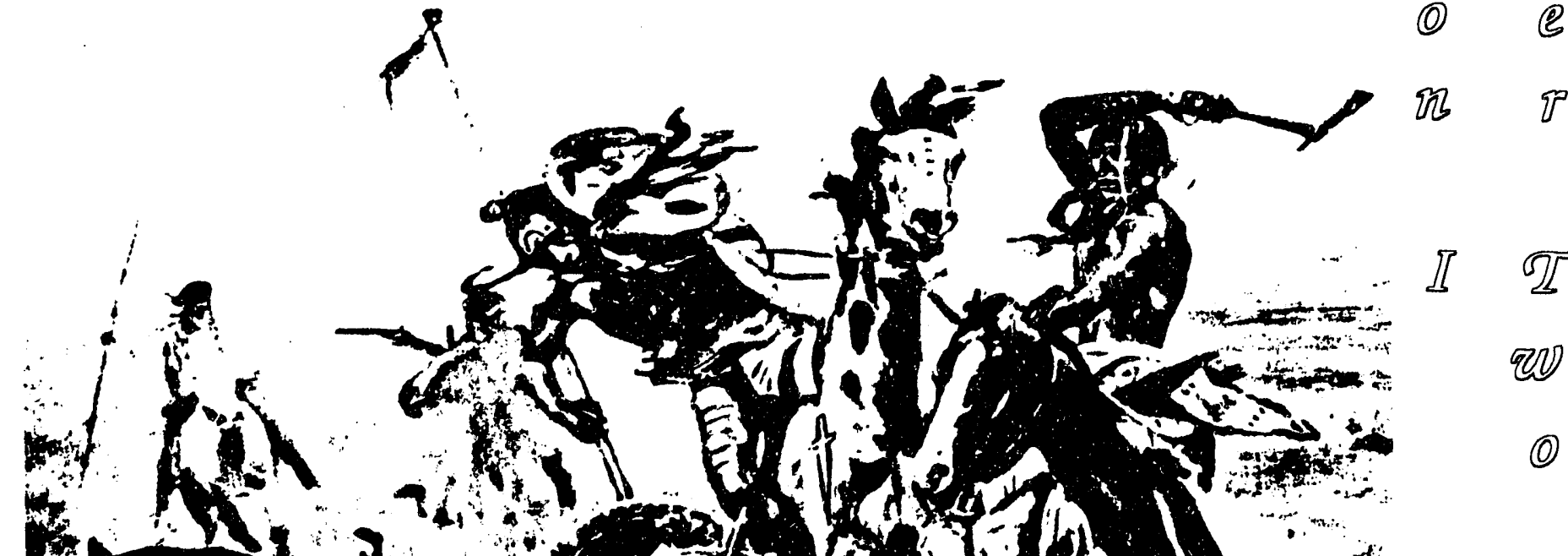
(4)

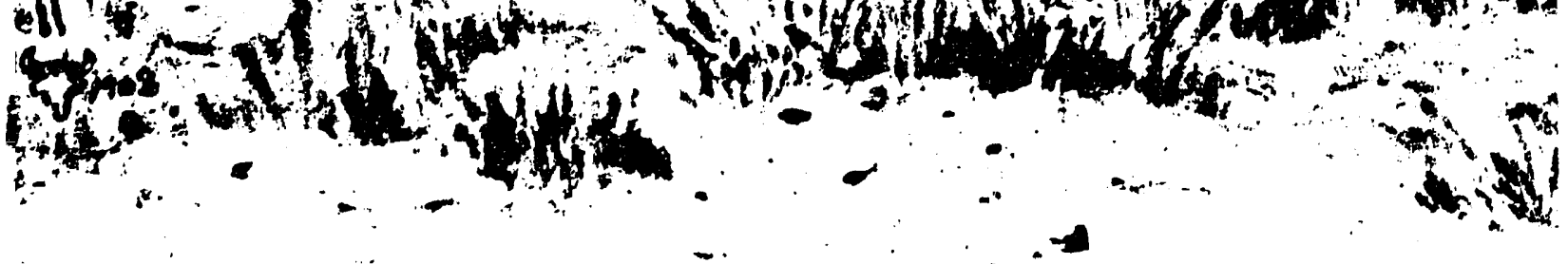




\section{SECTION I \\ UNDERSTANDING THE WASTE MANAGEMENT SYSTEM AND A MONITORED RETRIEVABLE STORAGE FACILITY}

\section{Chapter Two \\ WHAT ARE THE FACTS ABOUT EXPOSURE TO RADIATION?}

\begin{abstract}
Editor's Note:
Because of the great abundance of frightening misinformation about nuclear material, a careful examination of the facts should be presented without bias. It is also important to understand today's handling and storage techniques, in order to understand why not one fatality has occured in the U.S. from exposure to spent nuclear fuel.
\end{abstract}

\section{BIOLOGICAL EFFECTS FROM DIRECT EXPOSURE TO SPENT NUCLEAR FUEL}

Because of today's handling techniques, direct exposure to spent nuclear fuel has been reduced to a virtual impossibility, because those who handle it are so well trained and are closely supervised by facility managers and by government inspectors. These measures will be explained in more detail later in this report.

\section{Types of Radiation}

Alpha Radiation: The least harmful type, Alpha Radiation is found in nuclear materials with long half-lives. Radioactive particles of the Alpha type can be stopped by an ordinary piece of paper. These particles do not have the ability to penetrate human skin, however they can cause harm if they enter the body through a cut, are inhaled, or are ingested in food or water. Once inside the body, Alpha particles begin to decay, but can cause severe local damage to tissues.

Beta Radiation: More penetrating than the Alpha type, some Beta particles can penetrate human skin, but similar to Alpha particles, do more harm when inhaled or ingested. The chemical structure of some of the isotopes within Beta emitting material lead them to specific parts of the body (i.e., Strontium 90 is led to the bones of the body) where it may remain and cause further damage to surrounding tissues and organs. Beta emitting material is found in spent nuclear fuel.

Gamma Radiation: Similar to $X$-rays in their properties, Gamma Rays have much more penetration power and can inflict very serious damage to human organs and tissues. Gamma Radiation is found in spent nuclear fuel. 


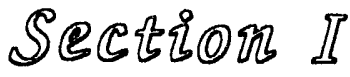

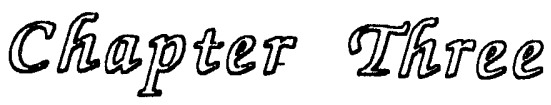

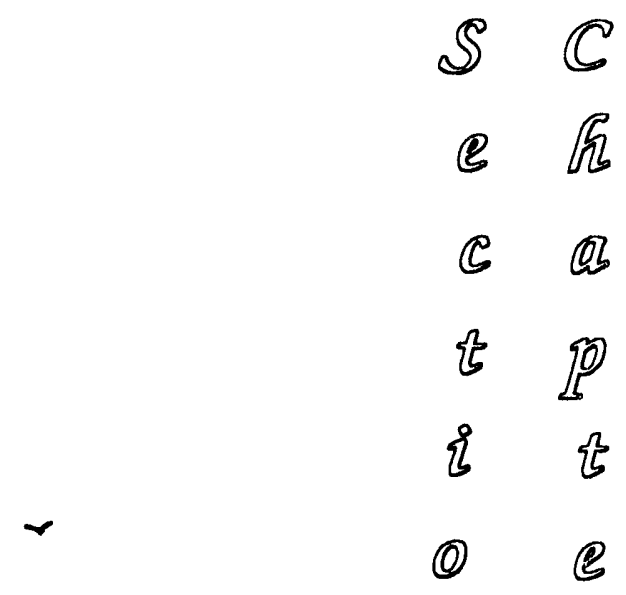

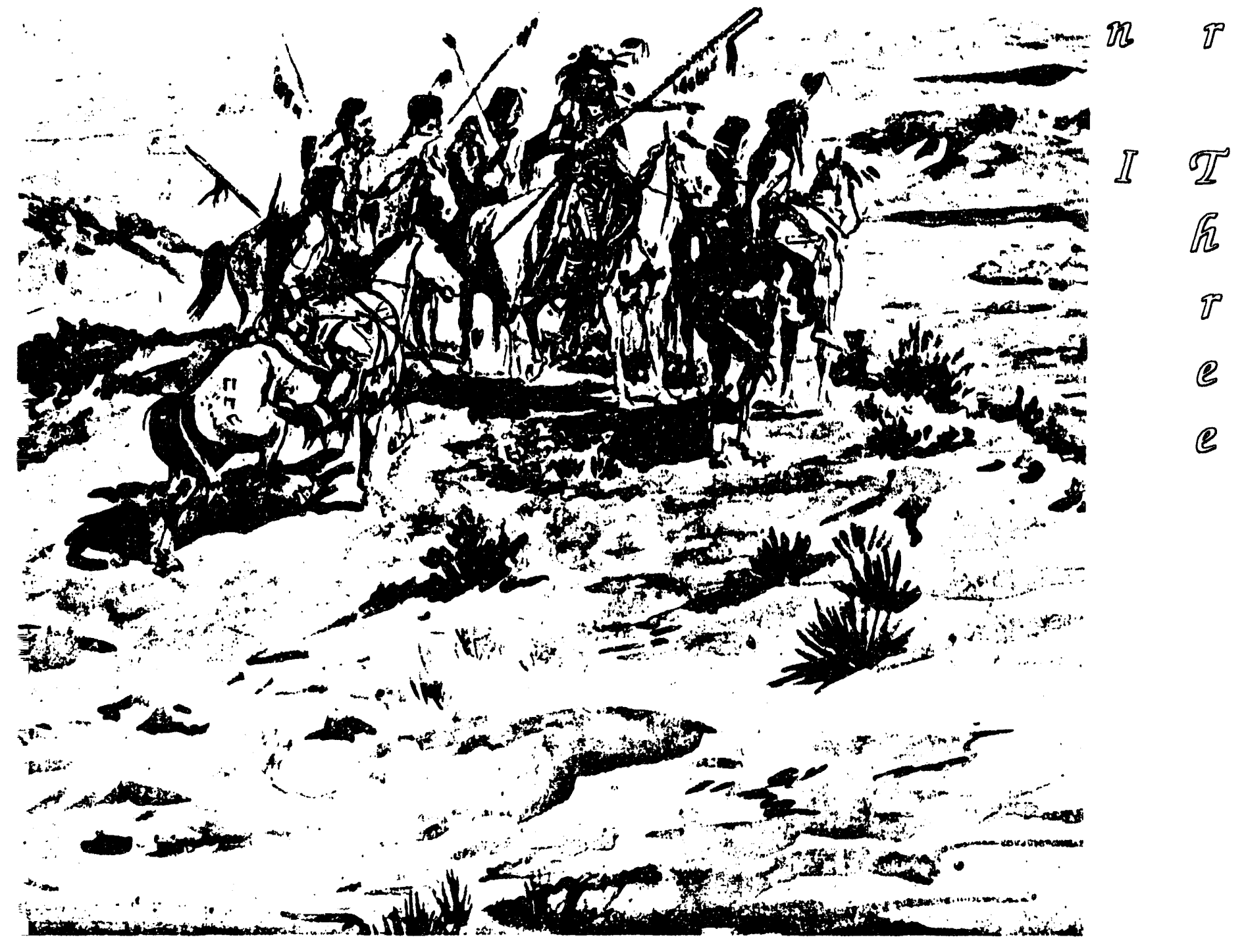




\section{SECTION I \\ UNDERSTANDING THE WASTE MANAGEMENT SYSTEM AND A MONITORED RETRIEVABLE STORAGE FACILITY}

\section{Chapter Three HANDLING, STORAGE, AND TRANSPORTATION TECHNIQUES}

\begin{abstract}
Editor's Note:
As indiceted earlier, under the heading "Biological Effects" on the previous page, today's handling techniques have resulted in not one fatality in this country due to exposure to spent fuel.
\end{abstract}

\section{Handling}

The handling of nuclear fuel is always performed under "shielded" conditions; i.e., humans and the environment are always protected by a barrier through which radiation may not pass.

\section{New Fuel Assemblies}

When nuclear fuel is manufactured, uranium oxide (U-235) pellets are made and inserted into stainless steel tubes clad with zirconium, to guard against deterioration. The tubes, which measure about 3/8 in. in diameter and are12 ft. long, are aranged into fuel assemblies, which are $12 \mathrm{ft}$. long and approximately 10 inches square at the end. *

"NOTE: Another form of fuel assembly has been experimented with; a nuclear power plant at Fort St. Vrain, Colorado, operated by Public Service Company of Colorado, used "uvel cells" made of a graphite compound. The cells were filled with small pelletized uranium oxide pellets and used a "gas transfer" technique, rather than the conventional "water transfer" technique used by other plants. Because of research costs, the technology became too expensive--theplant is now in the process of being decommissioned and converted to a gas-fired plant.
It may be interesting to note that new fuel assemblies are not dangerously radioactive--it is only after they are placed in the reactor of a nuclear power plant, and fission takes place, that they become radioactive.

New fuel assemblies are delivered in shielded containers to the nuclear power plant, then transferred into "holding cells" until put into use in the reactor, where the process of "fission" provides the heat to transform water to steam to drive the turbines.

\section{What is "Fission"?}

Within the center of an atom, there are several types of particles; one of these is called a "neutron", and is used, like a bullet, to "shoot" a whole atom and break it apart, freeing the second atom's neutrons to serve as more "bullets", and so on in a chain reaction. This chain reaction is called "Fission" and causes heat. Fission takes place in the "core" of the reactor.

\section{How is the heat used?}

Outside the core of the reactor, where fission takes place, is a "water jacket", under pressure to keep the water from boiling. Because it is under pressure, it may be heated to very high temperatures by the fission process. Purified water is then pumped through tubes surrounding the boiler to be turned into steam, which drives the turbines to produce electricity. 
What happens when the fuel is "used up"?

The newer, more radioactive fuel assemblies are arranged to the center of the core, while the "cooler" ones are moved to the ouside of the cluster within the reactor. A fuel assembly usually lasts about five years before it is removed for storage.

What happens to fuel assemblies after they are removed from the reactor?

When the spent fuel assemblies are removed from the reactor core, they are taken to a "storage pool"; an indoor pool of water which is 25 feet deep. Inside the pool, there are individual stainless steel cells designed to contain each fuel assembly. The water is "boronated", or has boron introduced into it to provide extra shielding. It is safe to stand on the pool deck without additional protection.

After approximately five years of "cooling" in the pool, the fuel assemblies are then removed for dry storage..... a transport cask is lowered into the water where the cooled fuel assemblies are transferred from their pool cells.....the entire transfer process takes place under water. After the transport cask is loaded, the cask is double sealed and raised above the pool, while being constantly flushed with water hoses to prevent contamination to the outside of the cask. The cask is then drained and dried above the pool before being loaded on a truck to be taken to dry storage. All underwater activity is performed with cranes while the entire process is monitored by underwater television cameras, including inventory of each fuel assembly by serial number.

\section{Transportation and Storage Casks}

Although there are several designs of storage casks, they all have several things in common:

a. They must completely contain all radiation from the inside, without leaks.

b. They must remain intact by enduring an incredibly stringent series of destructive tests, which include dropping them onto concrete from $40 \mathrm{ft}$., dropping them upon a large spike and resist puncturing, enduring blazing fires fueled with jet fuel, remain intact when crashed on a truck bed into a concrete wall at 80 miles per hour, and even through a truck/train collision.

c. After they have endured and passed all of this testing, they must be licensed by the Nuclear Regulatory Commission.

\section{Transporting Spent Nuclear Fuel}

As indicated in the above paragraph, spent nuclear fuel is transported in specially designed, nearly indestructible casks aboard flatbed semi-trucks. Special routing keeps them on safe highways and care is taken to assure 


\section{SECTION I \\ UNDERSTANDING THE WASTE MANAGEMENT SYSTEM AND A MONITORED RETRIEVABLE STORAGE FACILITY}

against accidents. In the more than twenty years that spent nuclear fuel has been transported, there have been highway accidents, but never has a cask been breeched. Additionally, spent nuclear fuel is transported in specially designed casks on flatbed railroad cars without incident.

\section{What is currently being done with Spent Fuclear Fuel?}

Of the 111 nuclear power plants in the U.S., nearly all store their spent fuel assemblies in their own spent fuel pools; three plants operate their own dry storage facilities; Virginia Power \& Light at Surrey, VA, Duke Power \& Light at Okonnee N.C, and Public Service Co. of Colorado at Fort St. Vrain, CO.

Why do we need a Monitored Retrievable Storage Facility?

\section{Federal Legislation}

As mentioned earlier in this Report, legislation passed by Congress in 1982 and 1987 mandated that the Federal Government would accept responsibility for spent fuel storage by 1998.

Work is being done to prepare a permanent underground repository at Yucca Mountain Nevada, but will not completed for many years; because of the time constraints created by this legislation, the Federal Government has little choice but to establish an interim storage facility.

Under the current plan, the Monitored Retrievable Storage Facility will be licensed by the Nuclear Regulatory Agency for a period of 40 years; the license is renewable. Although the Monitored Retrievable Storage Facility is referred to as "temporary", there is sufficient reason to expect that it could become a much longer-term facility.

\section{Spent Nuclear Fuel as a Resource?}

Also as mentioned earlier in this Report, people in some scientific circles consider spent nuclear fuel to be a potential resource; some applications include:

a. Reprocessing of spent nuclear fuel to be "recycled" and reused in power plants as is currently being done in Great Britain and France.

The drawbacks are the production of small quantities of Plutonium and the radioactive waste being converted from solid to liquid state, requiring it to be vitrified into glass logs for permanent storage.

Research might be done to determine whether the liquid waste has feasible application.

b. In some scientific circles, there is credible suspicion that spent nuclear fuel has economically valid applications in medicine. It has been suggested that 


\section{SECTION I \\ UNDERSTANDING THE WASTE MANAGEMENT SYSTEM AND A MONITORED RETRIEVABLE STORAGE FACILITY}

serious research be performed in Radiology and Oncology.

c. There has been some speculation that applications might be developed for some industial uses, and for power sources within satellites or other space vehicles.

\section{EDITORIAL COMMENT:}

Reasons have been articulated which support the underground storage of spent nuclear fuel as "the ultimate answer" to its disposal. Underground storage is a permanent measure and appears to be a wasteful one. It also eppears to many that we, as inhabitants of our period in history, owe it to future generations to more fully explore uses for what seems to be valuable potential resource. Certainly, money spent upon establishing an underground reposifory could be applied toward researching applications for spent nuclear fuel.

It is eppropriate to ssk ourselves the following questions:

1. Do we really want to permanently dispose of a potentially valuable non-renewable resource and deprive future generations?

2. We know that the half-life of spent nuclear fuel will last for thousands of years; one document estimated that span to be 24,000 years--are we capable of building a storage cask which will outlast that half-life within an underground environment, which is - ubject to natural forces and elements, particularly earthquakes and moisture? Further, if the underground site chosen (currently, Yucca Mountain, Nevada) is found to be safe in our lifetime, will it remain - safe repository for 24,000 years?
3. Is it a responsible act to continue with full scale mining and full scale disposal when there are such negative ecological consequendes?

The current popular argument against reprocessing, es is done in Great Britain and France is that "it is less expensive to mine new uranium and manufacture new fuel than to reprocess used fuel". What about the costs of permanent storage, not to mention the ecological losues of full-scale mining and the perpetual build-up of stored material?

It appears to be a more responsible scientific, ecological, and financial plan to store spent nuclear fuel in a Monitored Retrievable Storage Facility (or facilities), where access to the material and to the cesks is easily and safely achieved, coupled with on eggressive research program to benefit this and future generations. 
Section II

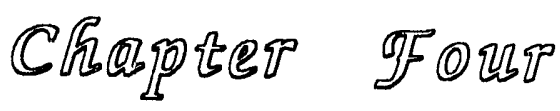

$S \mathbb{C}$

e

(c)

if $P$

i is

(1)

泟

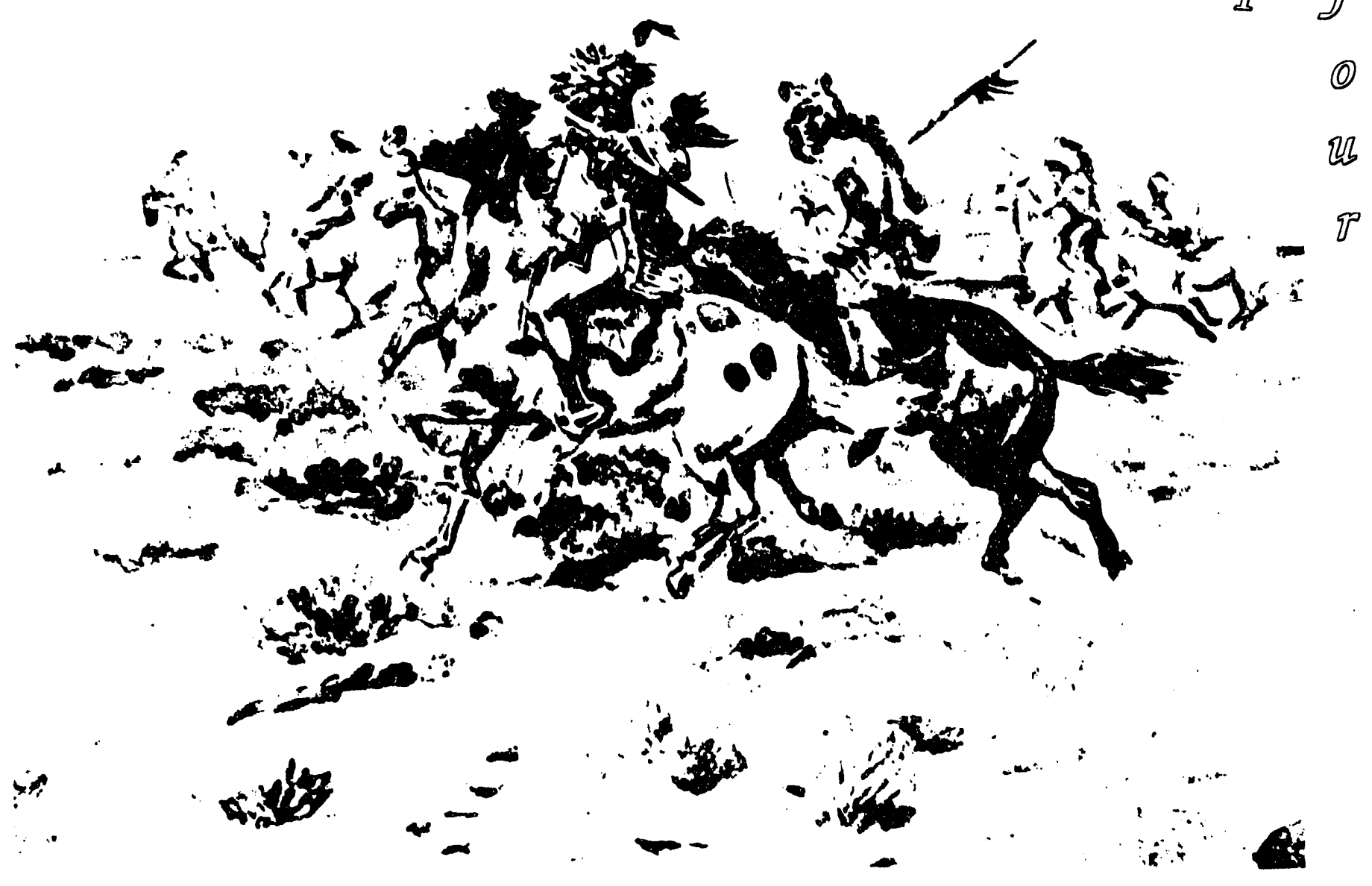


SECTION I

UNDERSTANDING THE WASTE MANAGEMENT SYSTEM AND A MONITORED RETRIEVABLE STORAGE FACILITY

\section{Chapter Four \\ DESCRIPTION OF A PROPOSED MONITORED RETRIEVABLE SI ORAGE FACILITY}

\begin{abstract}
Although a Monitored Retrievable Storage ("MRS") Facility has not yet been built, Congress mandated that it be ready to receive spent nuclear fuel by 1998.
\end{abstract}

It will occupy approximately 500 acres and will resemble an industrial park. The vaults which will hold spent nuclear fuel assemblies will likely use one of three technologies in use today at three of the 111 nuclear power plants:

1. Dry Cask Storage: An outdoor facility, with an earthquake proof pad of concrete three feet thick and "earthquake" steel reinforcing. Upon the pad, special outdoor storage casks are placed which have been tested to withstand lightning, artillery fire, fire fueled by jet fuel, etc. The casks are constantly monitored for radioactivity, gasses, moisture, etc., as a safety measure. The area is double-fenced with razor wire, motion detectors, and video monitors.

2. Indoor Vertical Vault Cells: Ar. indoor facility, made of high-density concrete, with special vertical vaults to receive spent fuel assemblies and a shielded transfer station to remove them from transportation casks and transfer them to permanent vault cells.
3. Indoor Horizontal Vault Cells: An indoor facility, similar to \#2, above, with horizontal vaults. 


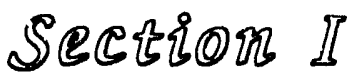

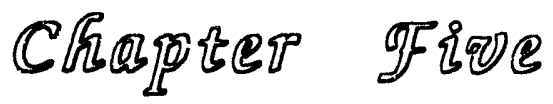

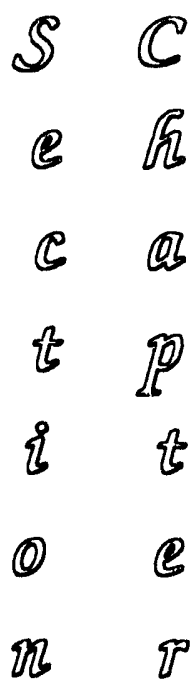

If IF

i

ข)

Q

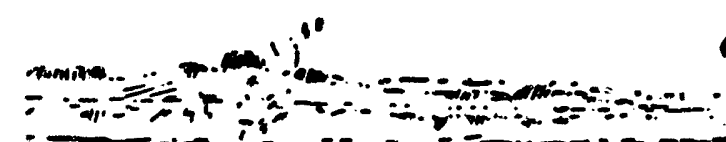

santor
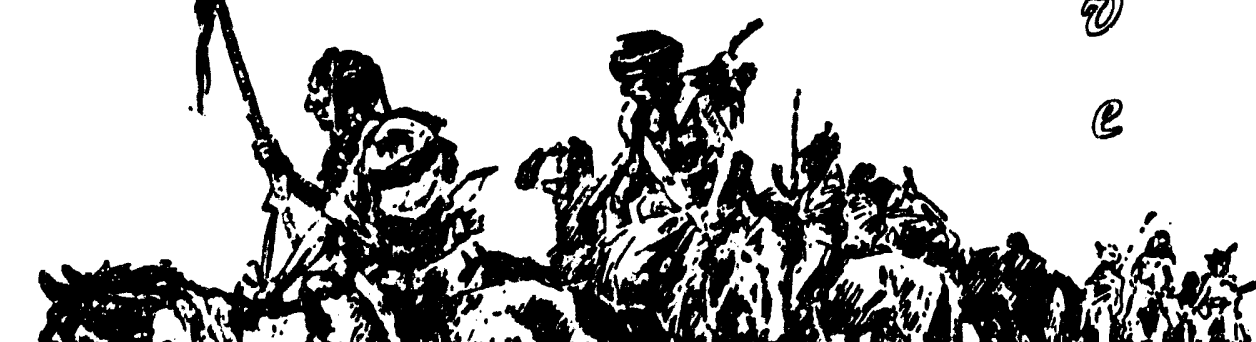
0,2 , th

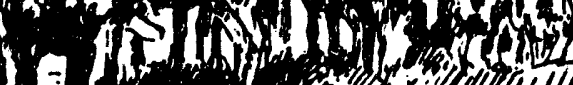

(1)

(1) $4 x^{2}=\frac{1}{6}$ ì

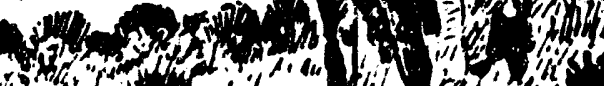

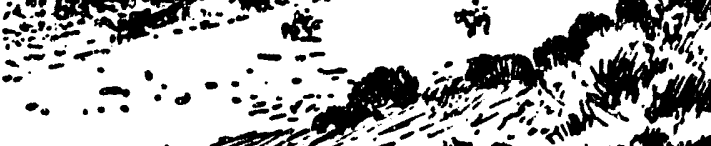

vasidy (3) 2 .

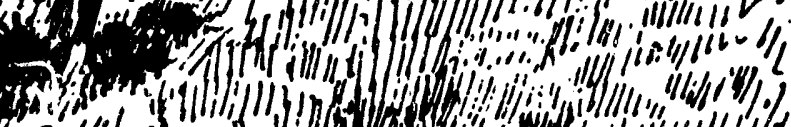

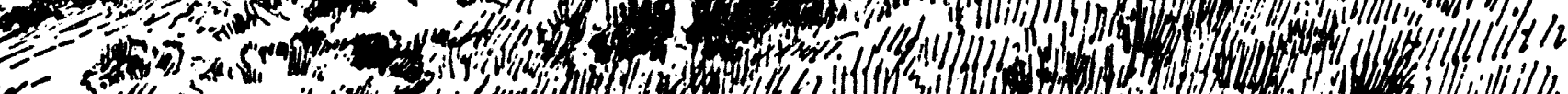

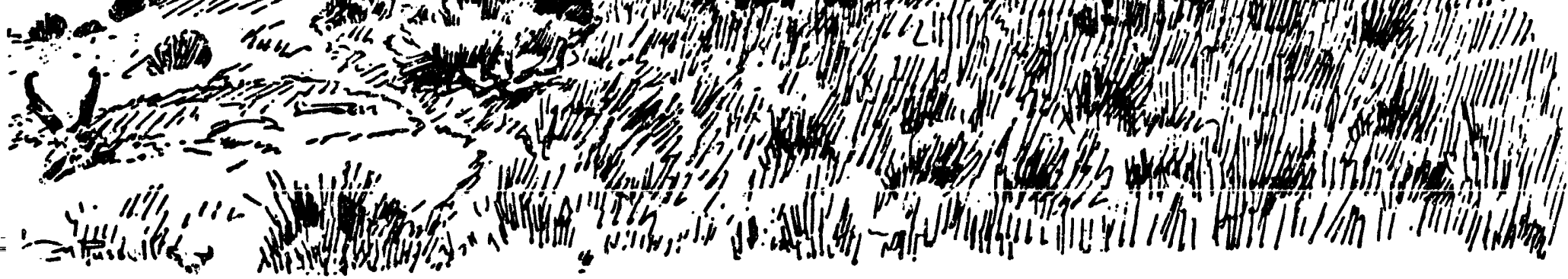




\section{SECTION I \\ UNDERSTANDING THE WASTE MANAGEMENT SYSTEM AND A MONITORED RETRIEVABLE STORAGE FACILITY}

\section{Chapter Five} BENEFITS TO BE RECEIVED BY HOST JURISDICTION

\section{Direct Income}

The U.S. Departement of Energy estimates that direct annual income to the Host Jurisdiction will range between $\$ 10$ million and $\$ 100$ million per year. Taxes upon the value and operation will be paid to the Host Jurisdiction just as if the MRS were a private business.

\section{Infrastructure Improvements}

The Department of Energy has made the offer to improve roads, highways, and bridges leading to the MRS. In addition, spokesmen for DOE have expressed a willingness to provide money for the improvement and operation of schools.

\section{Industrial and Commercial Opportunities}

We view the opportunity to host the MRS as an opportunity to launch related and unrelated enterprises; although specific identity of the related enterprises planned remain proprietary at this writing, income from the MRS may be used to launch additional Ponca-owned businesses.

\section{Construction and Operating Speclifications}

Although the Nuclear Regulatory Commission enforces its minimum construction and operating specifications, the host jurisdiction may add to or increase them.

In addition, the host jurisdiction may negotiate the type of facility to be built; currently, the types being used are outdoor dry cask storage, vertical vault storage, and horizontal vault storage. As long as the proposed design meets minimum NRC specifications, the design criterea is also open to negotiation.

\section{Employment Opportunities}

It is estimated by the Department of Energy that the construction phase of the MRS will create as many as 700 jobs, and as many as 540 jobs will be created for operation of the facility.

Of course, we anticipate more jobs to be created as a result of the industrial and commercial opportunities described earlier on this page. 
SECLR요 II II

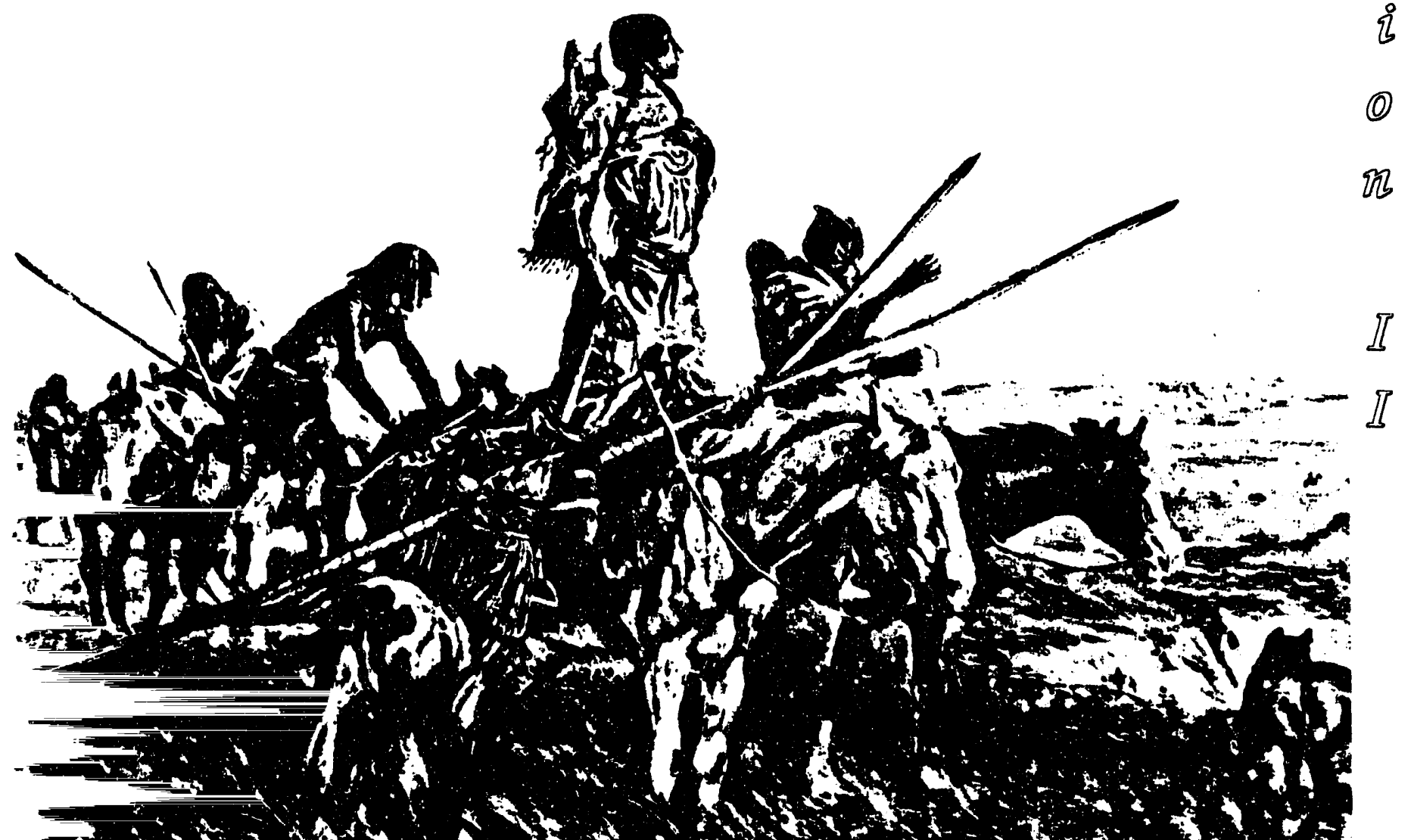

$\mathfrak{S}$

C

C

is

i

(1)

$\pi$

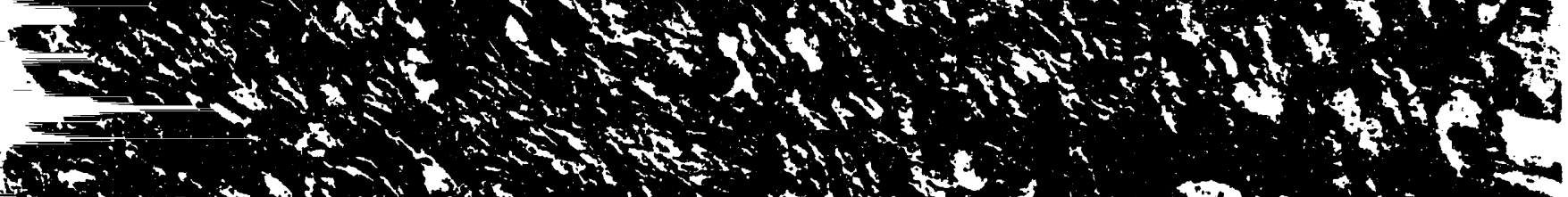
En

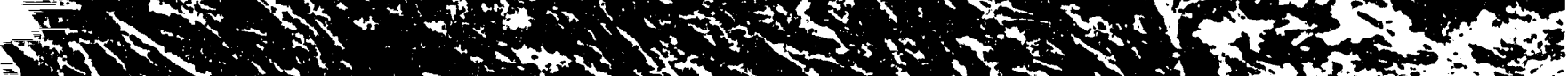
My

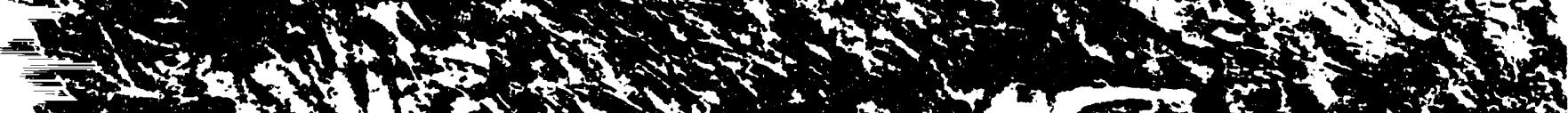

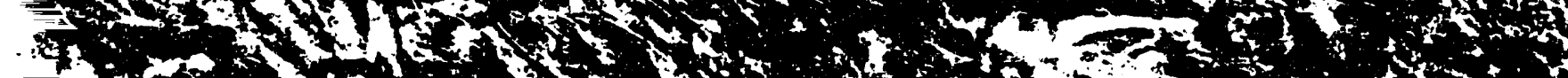

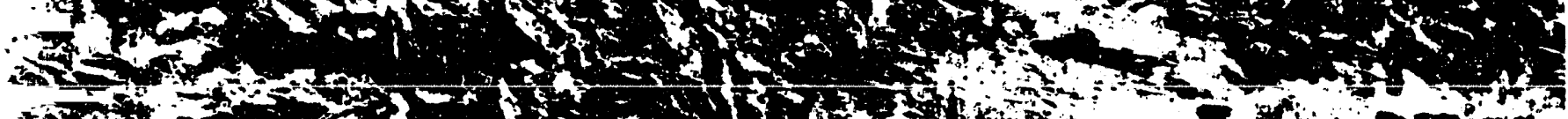

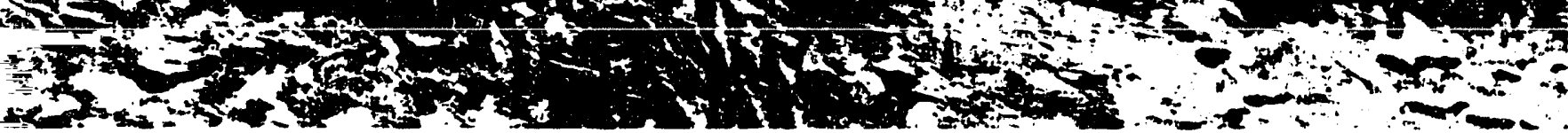




\section{SECTION II}

DETERMINE WHETHER THE APPLICANT HAS REAL INTEREST IN PURSUING THE FEASIBILITY ASSESSMENT PROCESS

\section{A Word about Ponca Industrial Corporation.....}

Ponca Industrial Corporation was formed to stimulate economic development for the Ponca Tribe of Oklahoma. Its founder, John W. King was appointed as Agent/Negotiator for the Ponca Tribe in matters pertaining to a temporary Monitored Retrievable Storage Facility and/or Permanent Repository, by means of a Resolution passed by the Ponca Tribal Business Committee.

King has recruited a large network of highly qualified consultants in the fields of business, technical, governmental, and public relations to aid him in his assignment.

\section{Conclusions Regarding Phase I}

As a result of investigations and work performed during Phase I, we have concluded that the process of handling, transporting, and storing spent nuclear fuel has been developed to a manageable and safe level by the NRC and firms engaged in the business, and that hosting an MRS would present an extremely attractive business, financial and employment opportunity for the Tribe without unduly compromising safety of the Members or prospective workers.

Although the Tribe has the right to refuse a final offer, by agreement with the U.S. Department of Energy, the U.S. Nuclear Waste Negotiator's Office, and with Punca Industrial Corporation, we have explored enough of the opportunity to drastically increase our level of interest in the Project.

\section{Steps taken in Preparation for Phase II; FEASIBILITY \\ ASSESSMENT PROCESS}

1. We have obtained agreement from two technical experts in the field of Nuclear Engineering to assist in the performance of Phase II; John W. Poston, PhD, and Wilson W. Pitt, Jr., PhD, of Texas A\&M University. Through Drs. Poston \& Pitt, we will have access to additional scientific consultation, as needed.

2. We have made preliminary preparations to organize a Public Information and Clerical Office on the Ponca Reservation, in order to fulfill the "Public Information and Dialogue" and "Governmental Dialogue" requirements as stipulated in Phase lla.

3. We have requested fresh Proposal Solicitations from the Department of Energy.

4. We have received sufficient support and encouragement from the Ponca Business Committee to proceed with our application for Phase Ila.

OUR REAL LEVEL OF INTEREST IS SUFFICIENT TO APPLY FOR

PHASE IIa, "FEASIBILITY ASSESSMENT PROCESS". 

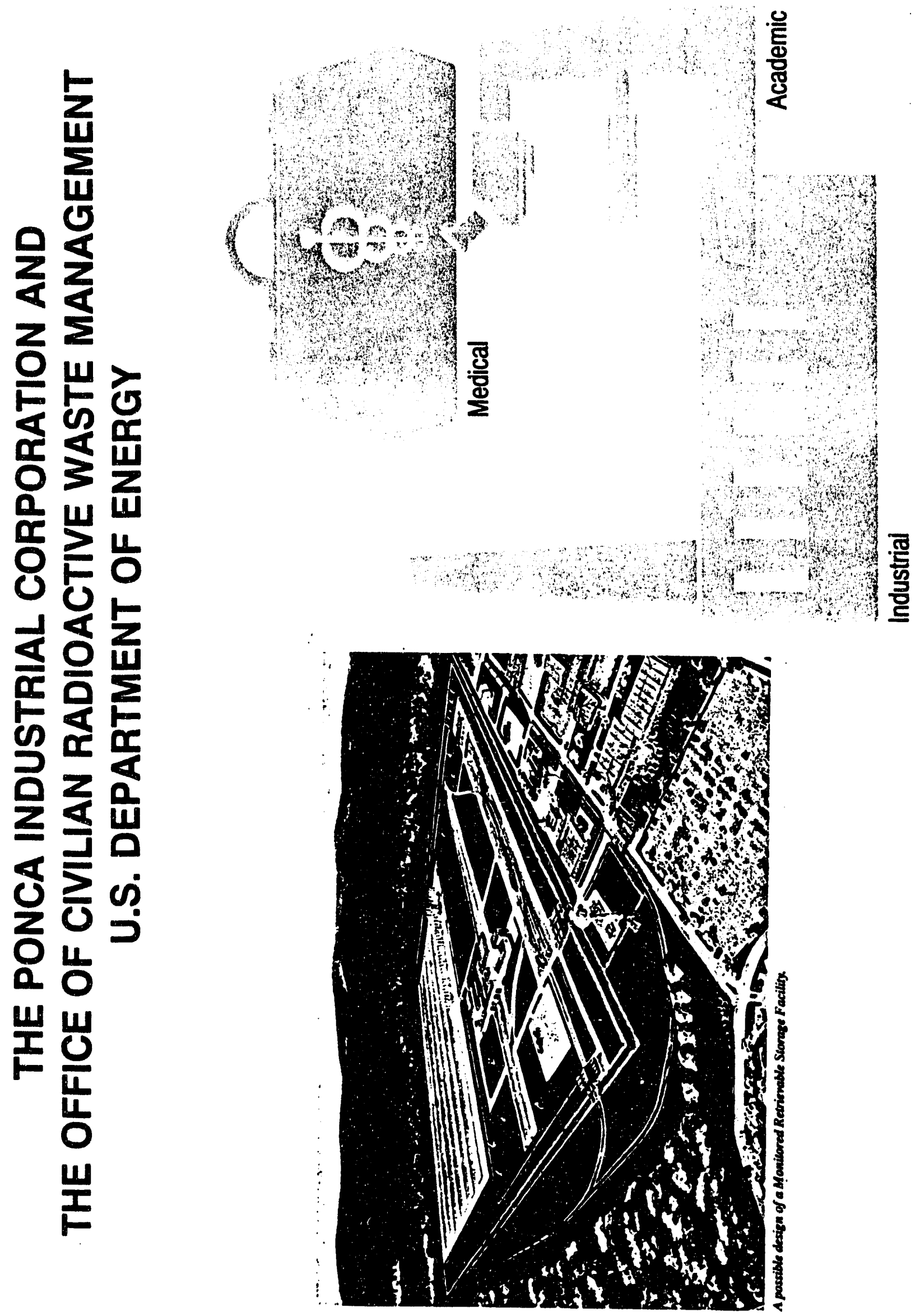
Figure 16. U.S. Commercial Nuclear Power Reactor Sites

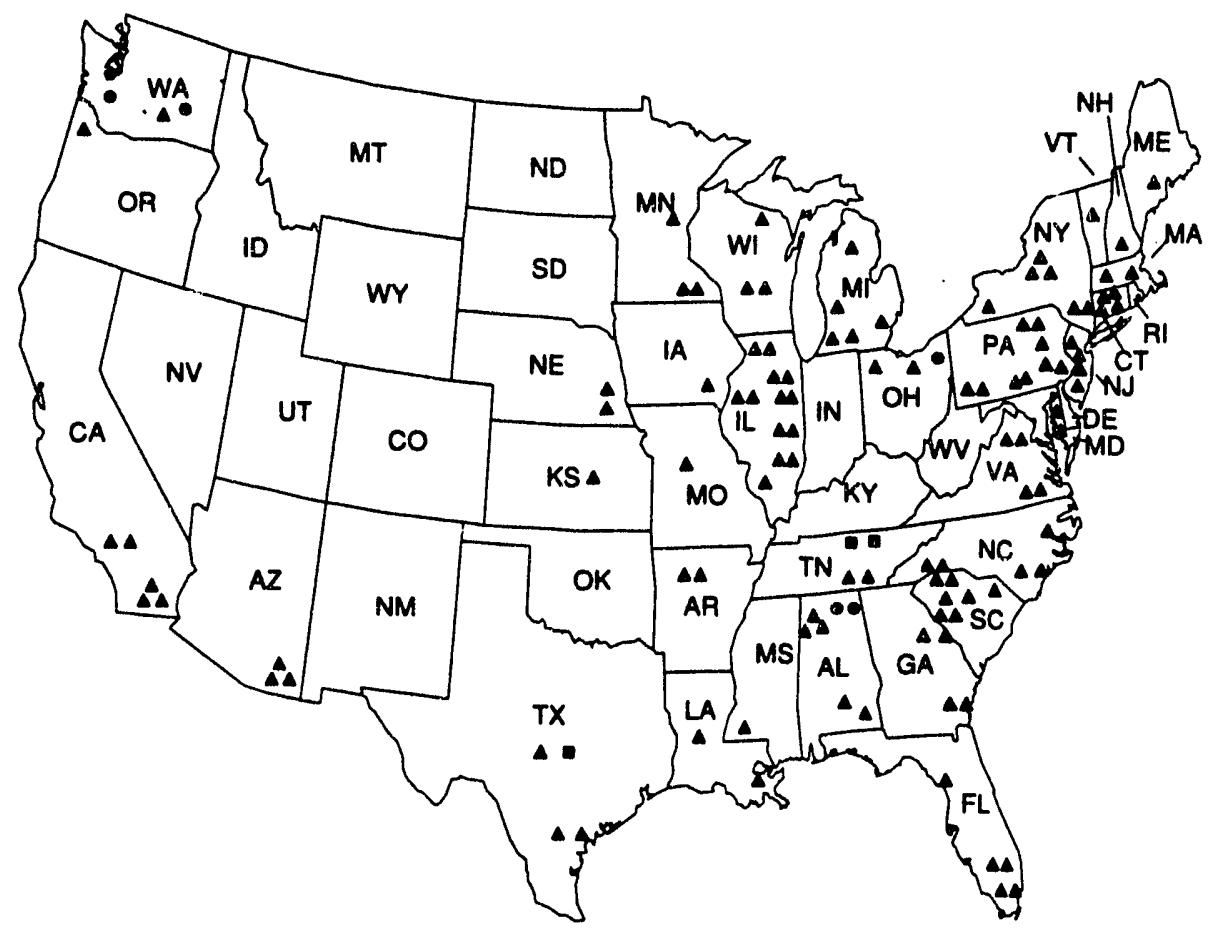

$\Delta$ Currently Licensed to Operate (111)

- Under Construction (3)

- Deferred Construction (5)

Note: There are no commercial reactors in Alaska or Hawaii.

Source: Nuclear Regulatory Commission 
Figure 31. NAC Agreement States

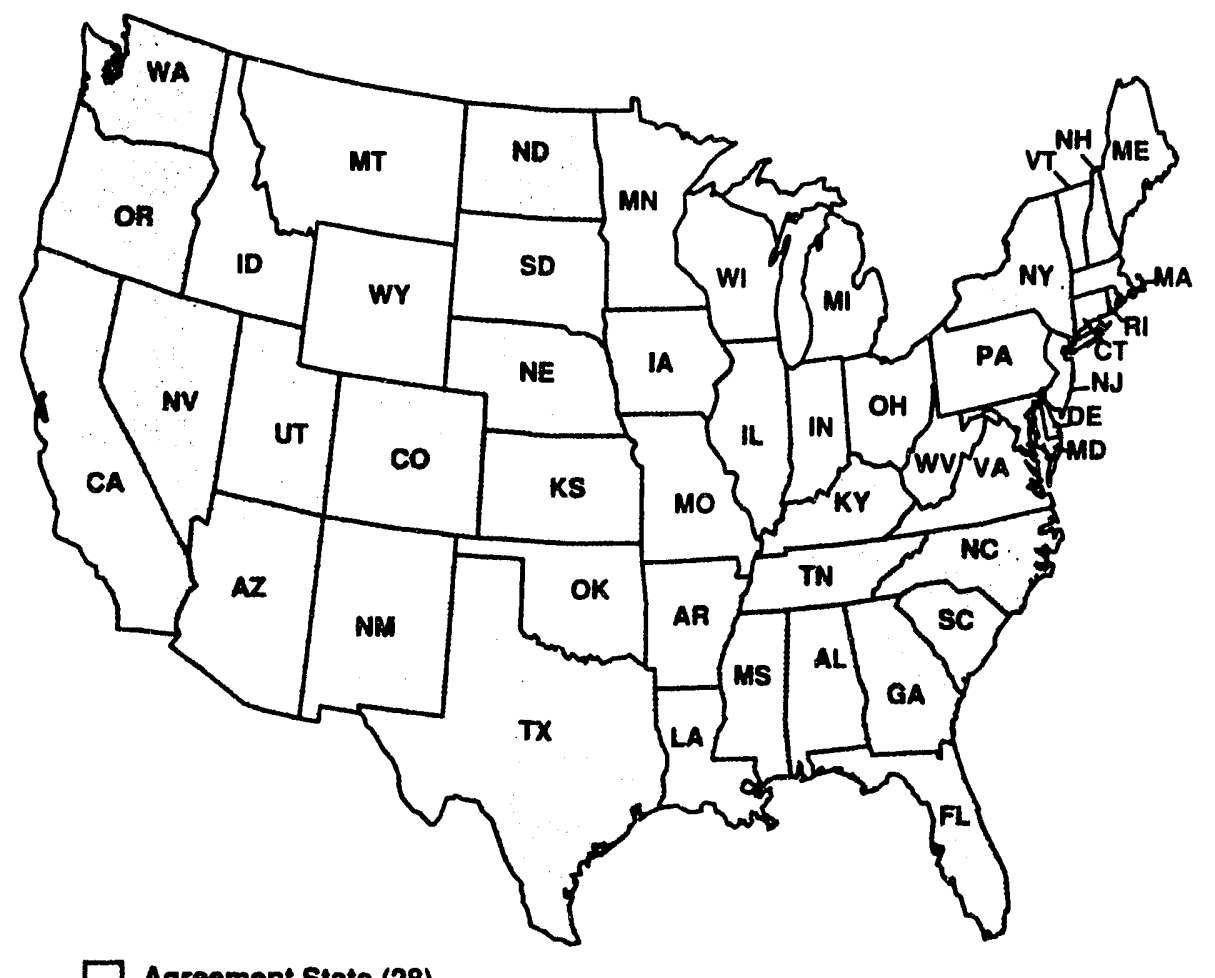

Agreement State (28)

Note: Data as of 01/31/92. The NRC is currently considering a request from Maine to become an Agreement State. Alaska and Hawaii are not Agreement States.

Source: Nuclear Regulatory Commission 
Figure 14. 1990 Net Nuclear Electrlc Power as Percent of World Nuclear and Total Domostlc Electricity Cieneration PERCENT OF WORLD NUCLEAR GENERATION

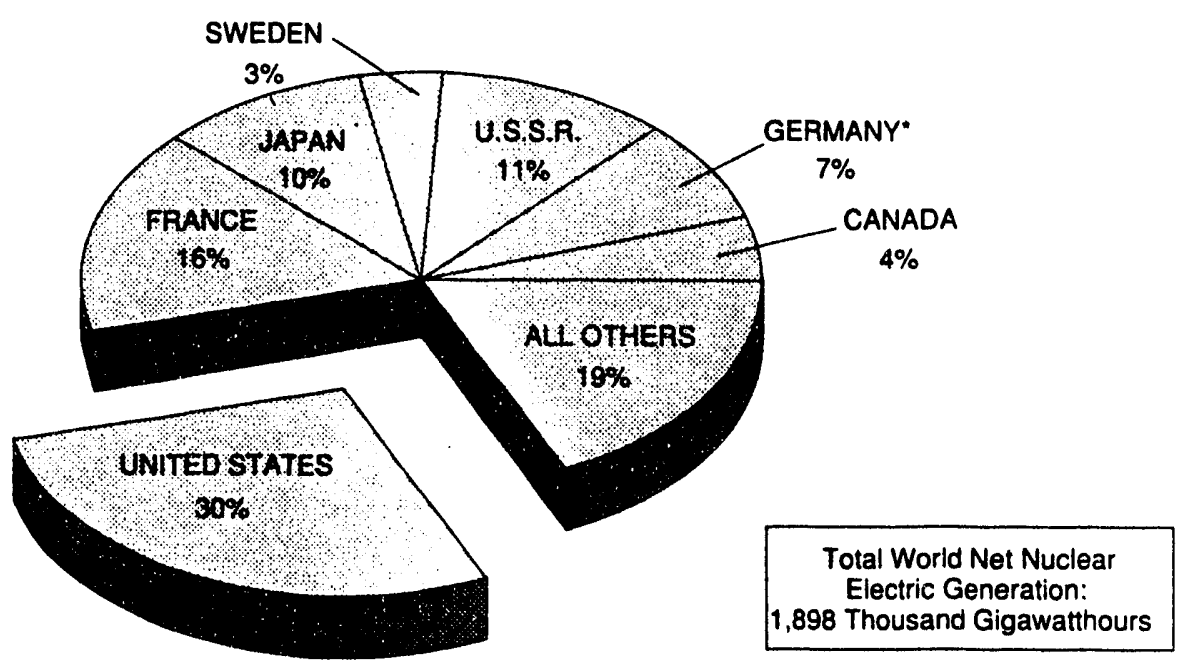

PERCENT OF TOTAL DOMESTIC NET ELECTRICITY GENERATION

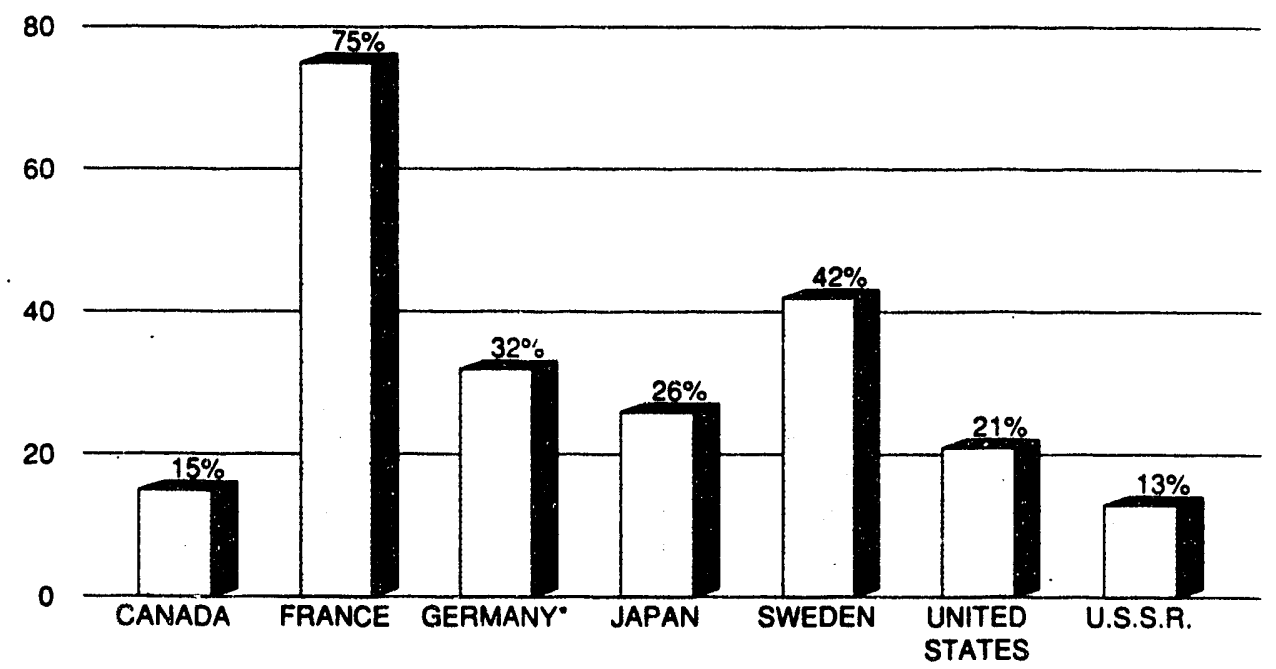

*Data are for West Germany only.

Note: Percentages are rounded to the nearest whole number.

Source: DOE/EIA International Energy Annual 1990 (DOE/EIA-0219(90)) 
Figure 9. 1990 Net Electrleity Generated in Each State by Nuclear Power

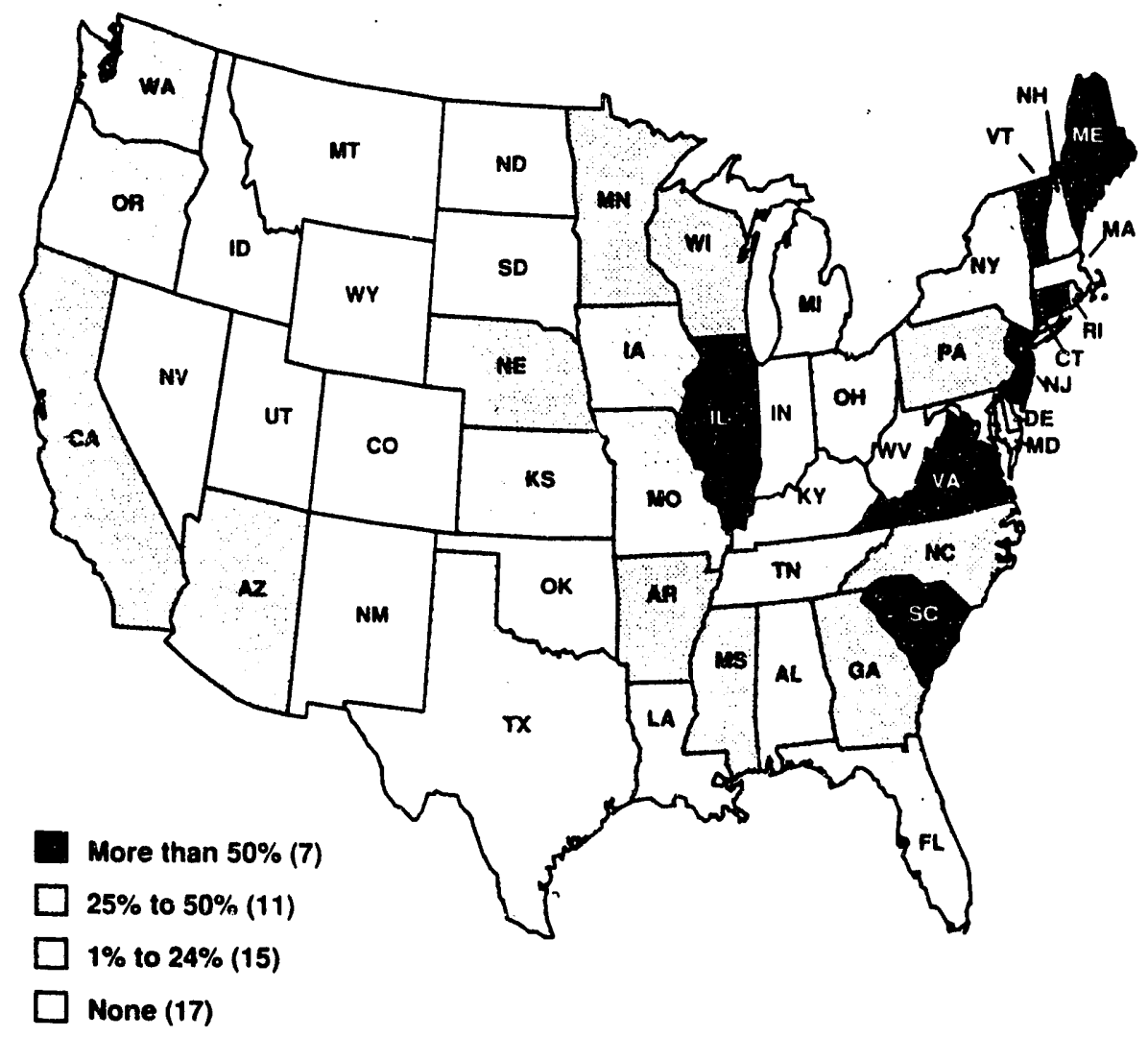

Note: There are no commercial reactors in Alaska or Hawaii. Percentages are rounded to the nearest whole number.

Source: DOE/EIA Report on Electric Power Generation 
Figure 8. 1990 U.S. Electric Capability and Net Generation by Energy Source
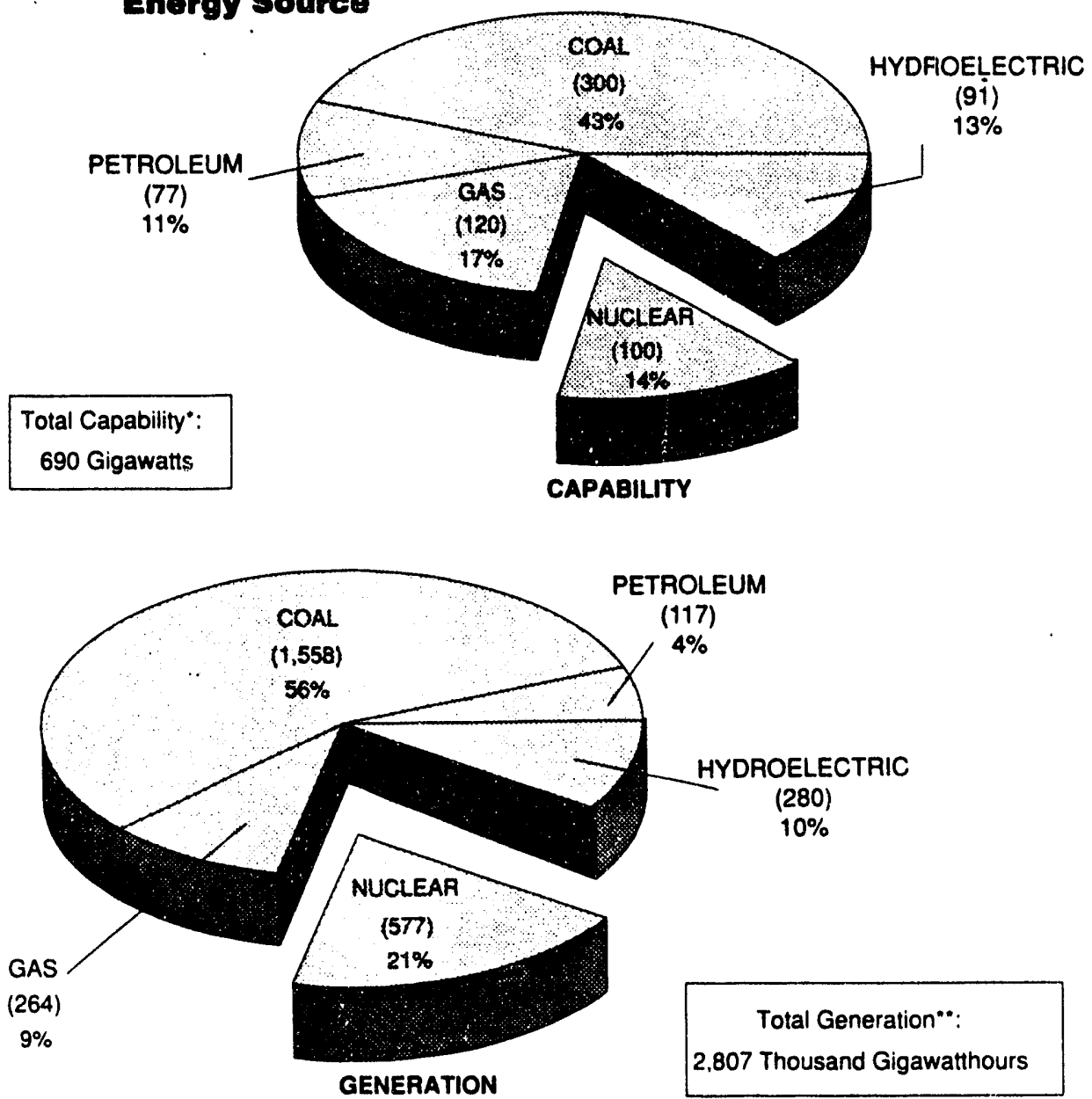

*Total does not equal sum of components oue to independent rounding. Total value includes approximately 4 gigawatts of other generating capability (geothermal, refuse, waste heat, waste steam, solar, wind, and wood), which represents less than 1 percent of total capability.

**Total value includes approximately 11 thousand gigawatthours of generation by other energy sources (geothermal, wood, wind, waste, and solar), which represents less than 1 percent of total generation.

Note: Net summer capability. Percentages are rounded to the nearest whole number.

Source: DOE/EIA Electric Power Annual 1990 (DOE/EIA-0348(90)) and DOE/EIA

Monthly Energy Review (DOE/EIA-0035 (91/12)) 

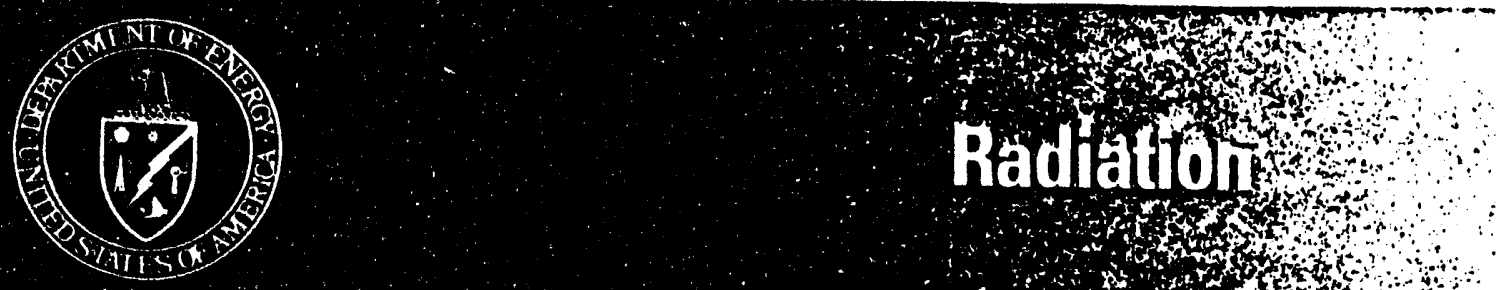

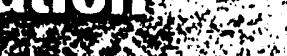

int

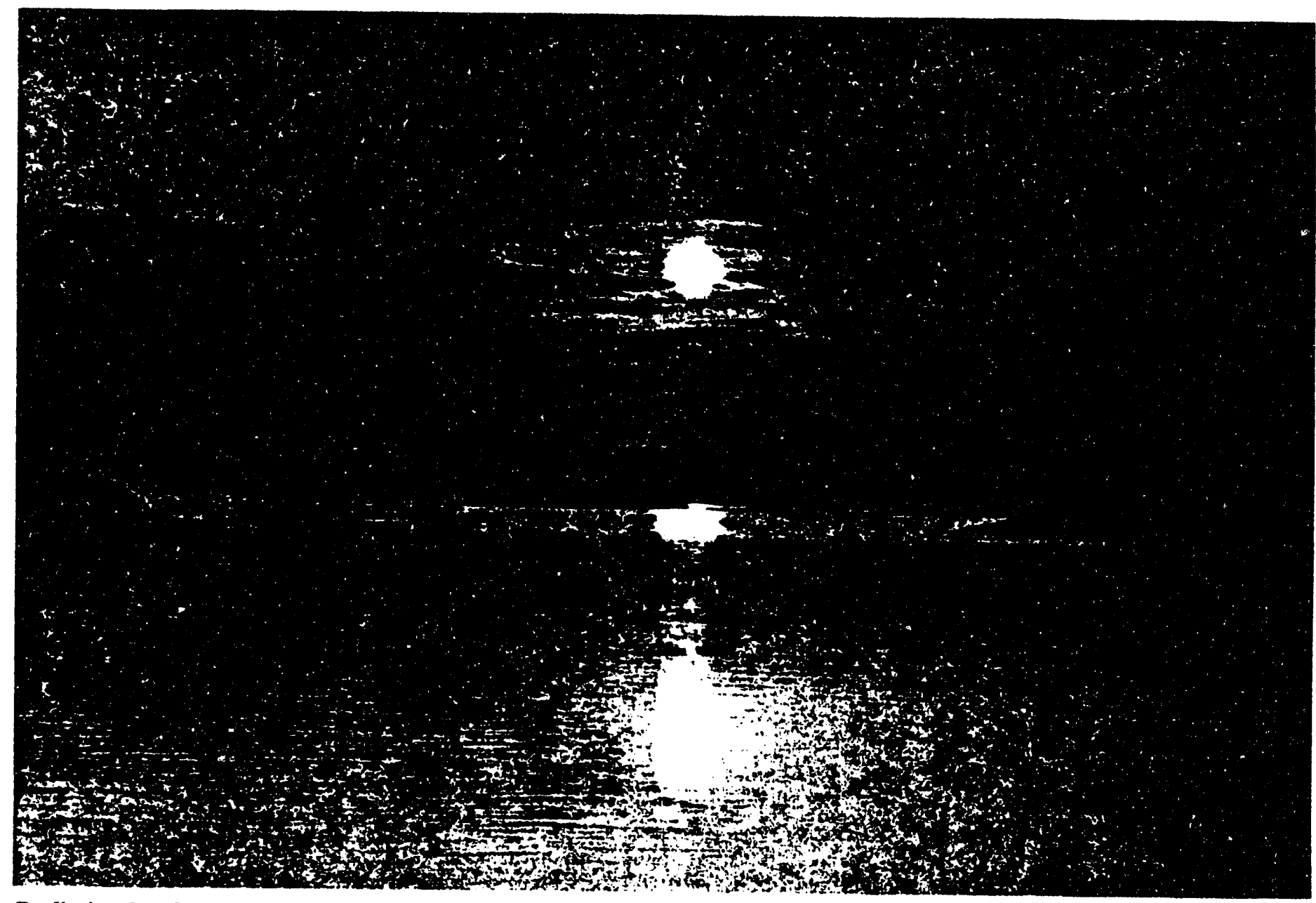

Radiation has been on the planet longer than man.

We live safely with radiation every day. It comes from the food we eat, the water we drink, from the earth and from the sun. In fact, radiation in some form or another has been on the planet longer than man.

More than three-fourths of the radiation we receive comes from natural sources like sunlight, soil and certain types of rocks. This is called background radiation.

Medical procedures like $\mathrm{x}$ rays and common household items like color televisions and smoke detectors are all sources of what is called man-made radiation, which accounts for the remaining fourth of our radiation exposure. There is no difference between natural radiation and man-made radiation. Last year approximately $10 \mathrm{mil}-$ lion nuclear medical procedures were performed in the United States. Diagnostic $x$ rays and/or radiation therapy helped millions of people get well.

The study of radiation begins with the atom. Atoms are the building blocks of the universe. Natural forces hold them together, and they make our world look the way it does.
Tremendous amounts of energy are stored in the centers - called the nuclei - of atoms. When atoms are split, two things are produced: one is heat, the other is radiation.

Radiation is measured in units called millirems. A millirem measures the effect of radiation on our bodies just as degrees measure temperature and pounds measure weight.

An average American's exposure to radiation is about 360 millirems per year. About 300 millirems of that 360 come from natural sources of 
radiation; 60 millirems cone from man-made sources. primarily medical procedures; and less than one millirem comes from the use of nuclear fuel.

Location also plays a part in how much radiation a person receives. $A$ person living in Egypt receives 300 to 400 millirems per year. A person living in Brazil receives 500 millirems per year. A person living in certain parts of India receives 1,300 millirems per year, more than three and one-half times as much as a person living in the U.S. receives.

\section{Examples of Dillerent Amounts of Radiation}

Standards for proiection of the public from the effects of radiation have been in existence for more than forty years. Maximum exposure for the general public from the operation of a nuclear facility licensed by the Nuclear Regulatory Commission, including a Monitored Retrievable Storage (MRS) facility, a Federal central storage facility for spent nuclear fuel, is 25 millirems per year. This limit is in accord with exposure standards set by the U.S. National Council on Radiation Protection and Measurement, the Intemational Commission on Radiation Prolection, and the International Atomic Energy Agency. Exposures far below this limit will be realized by employing conservative design fealures and adhering to strict writlen and approved operating procedures for all fuel handling operalions. Moreover, a management philosophy will be applied to facility operiltions to ensure that actual doses to the public will not only be below the allowable limit, but also as low as is reasonably achievable.

Actual exposure for any individual is expected to be far below the limit. even if liat individual were 10 stand at the MRS sitc boundary 24 hours a day for 365 days a year. A realistic estimate for exposure for an individual living nearest to the MRS facility is expected to be on the order of one or so millirems. This is the same amount of exposure that the average individual in the United States gets in one day due to natural background radiation. Compare this to the additional 5 millirems one would get from a one-week ski vacation in Denver, including the flight. The maximum exposure for a worker in a licensed nuclear facility is 5,(0)( ) millirems per year. The purpose of these, and the following comparisons, is not to trivialize the subject of . radiation exposure, but simply to place such exposures in perspective.

- A person living directly outside a nuclear power facility would add approximately I millirem per year.
- A person working in a nuclear power plant would add 300 or more millirems per year.

- From cosmic rays alone, a person living in Washington, DC, a city wills a low elevation, would receive approximately 26 millirems per year. A person living in Denver, Colorado, a city with a high elevation, would receive approximately 50 millirems a year.

- A person flying in an airplane across the country would alde about 5 millirems per flight because of the increased elevation during the trip. Airline pilots and flight altendants are exposed to higher levels of radiation routinely due to their occupations.

- A person receiving a full set of dental $x$ rays would add about 40 millirems per $y$ 'ear.

- A person working in a store on a street that a truck transporting nuclear waste passes by every week would add about one-hall a millirem per year.

- A person stuck in triffic for an hour next to a truck carrying nuclear wasle would add less than 10 millirems.

- A person silling on a park bench as a truck carrying nuclcar waste passes by would add less than oneemilh of a millirein.

For mure information, please write: OCRWM Information Center

Post Office Box 44.375

Washington. D.C. $2(X) 26$ or call: 1-8()-225-NWPA (or call 488.5513 in Washinglon, D.C.)

Puhlished by the U.S. Deparment of Eucrey Orlice of Civilian Radioactive Waste Management (OCRWM)

Please recycle. August 1992 

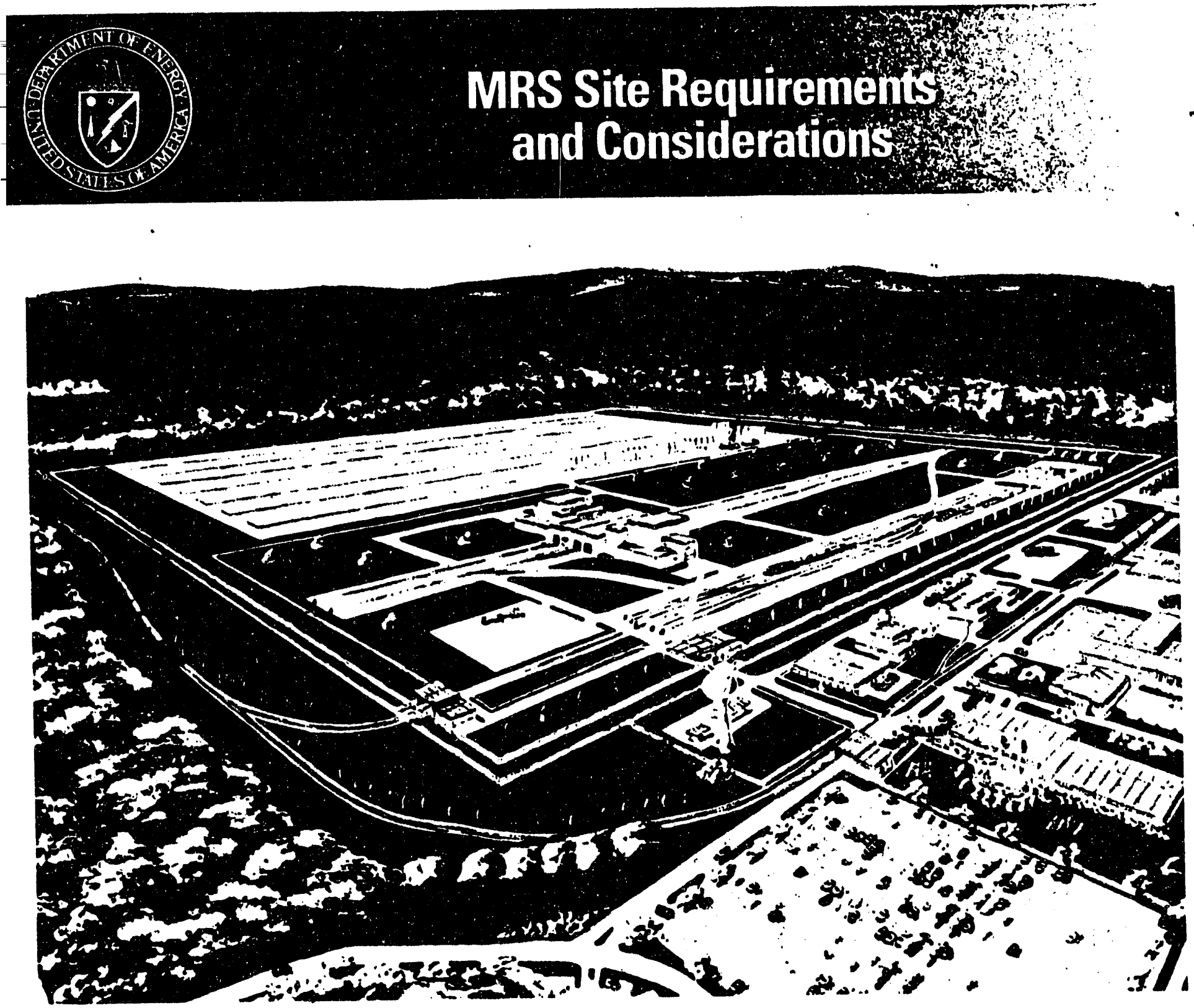

\section{A possible design of a Monitored Retrievable Storage Facility.}

The Monitored Retrievable Storage (MRS) facility is a vital part of America's Civilian Radioactive Waste Management System. "Spent" or "used" fuel from commercial nuclear power plants currently is being stored safely in protected areas at the plants, but those storage spaces are rapidly reaching capacity. The MRS will temporarily store a limited amount of this used fuel in thick-walled, aboveground engineered structures until it is shipped to a mined geologic repository for permanent disposal. The facility will provide additional, temporary storage space until the repository is operational.
When Congress authorized the Department of Energy to site and build an MRS, it included several restrictions for its use and operation. The restrictions are based on Federal laws, regulations, and executive orders that were in place before the MRS was proposed and some additional measures that were added to help ensure the safety of people and the environment.

\section{Site Requirements}

Specifically, six requirements mist be met:

- It should occupy between 400 and 600 acres of land
It should be located in a state other than Nevada, the state currently being studied for a permanent disposal site

- It cannot be within 200 feet of a geologic fault that has moved or shifted in the last 10,000 years, not near a 100-year floodplain, and not within or adjacent to wetlands

- It cannot be located in the habitat of any endangered species

- It cannot be located on land that is protected from development, like national parks and wildemess areas 
- It cannot be located within the Coastal Barriers Resource System, which consists of undeveloped land along the Atlantic and Gulf coasts and adjacent wetlands and inlets.

\section{Site Considerations}

Site considerations that may make one site preferable over another include:

- Land costs and how long it will take to develop the land for an MRS

- Proximity to transportation facilities like roads, railroads, and seaports
Impact on wetlands and coastal areas

- Geologic characieristics such as earthquake activity and floodplains

- Inpact on historical, cultural, and archaeological areas such as burial grounds, battlefields, and religious sites

- Proximity to human and animal activity

- Severe weather conditions that may affect operations

- Elasts or other major ground movement caused by humans
- Potential ground movement like landslides

- Volcanic activity

- Socioeconomic impact on potential host community

- Impacts on air quality

- Preservation of ground water quality

Land ownership and land use restrictions.
For more information, please write:

OCRWM Information Center

Post Office Box 44375

Washington, D.C. 20026

or call: 1-800-225-NWPA

(or call 488-5513 in Washington, D.C.)

Published by the U.S. Department of Energy Office of Civilian Radiaactive Waste Management (OCRWM)

Please recycle.

August 1992 
More than 110 nuclear power plants are operating safely in the United States. Nuclear power, while generating 20 percent of the nation's electricity, also produces a solid radioactive waste called "spent" or "used" nuclear fuel. This fuel is currently being stored in protected areas at the plants, but these storage facilities are rapidly reaching capacity.

To remedy this situation, Congress passed the Nuclear Waste Policy Act. This 1982 Act provides for the creation of a comprehensive Civilian Radioactive Waste Management System that is based on what most scientists agree is the best way to dispose of used fuel and other kinds of high-level radioactive waste.

A key component of this system is a Monitored Retrievable Storage (MRS) facility. The MRS will temporarily store a limited amount of the used fuel until it is shipped to a mined, underground permanent disposal facility.

\section{Choosing the MRS Site}

To find a site for the MRS, President George Bush appointed a Nuclear Waste Negotiator. The Negotiator is seeking a State or Indian tribe to volunteer to host the MRS in its jurisdiction. In return for hosting the MRS, the Federal Government has agreed to make contributions to the State or tribe and affected units of local government for public programs, projects, and other uses. It is the Negotiator's job to work out the terms of the

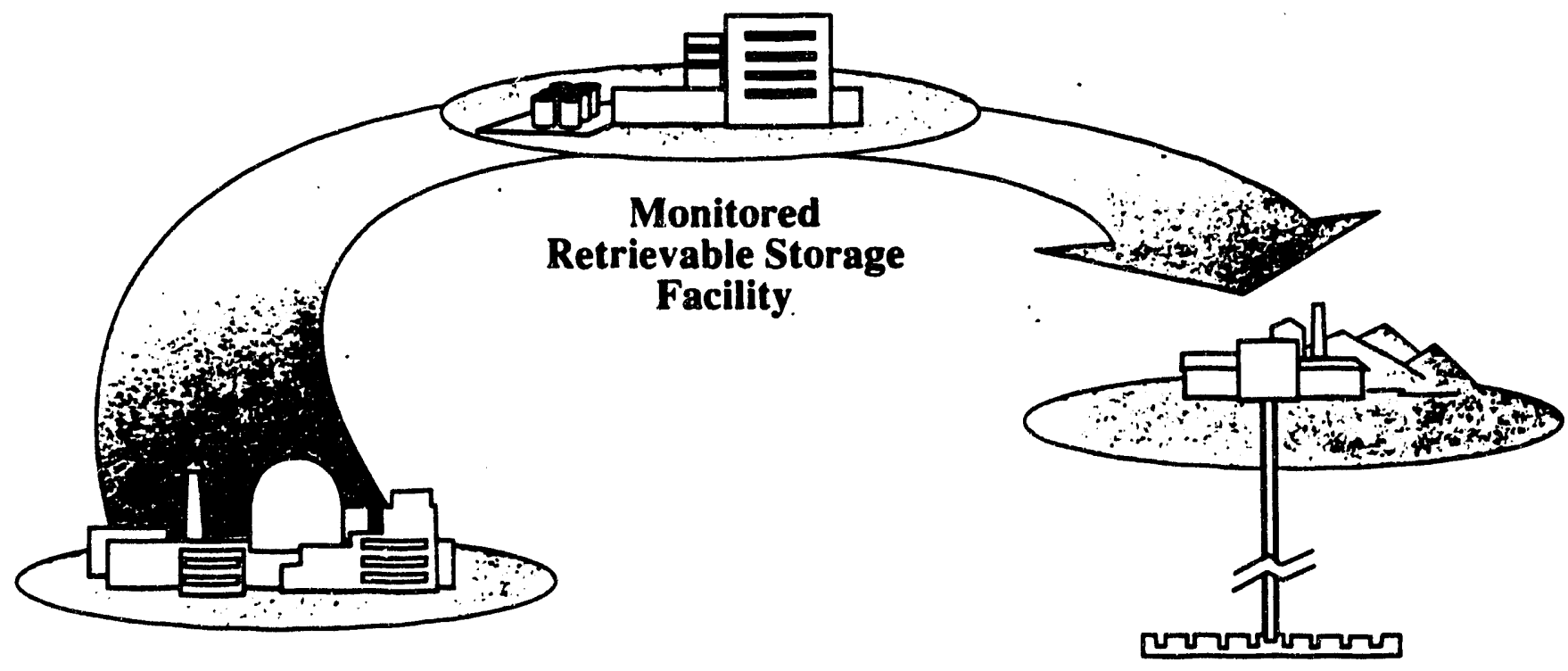

Nuclear Power Plant

Federal Repository

\section{Spent Fuel Storage and Disposal}

An example of the route nuclear waste will take from a nuclear power plant, to the $\bar{M} \bar{R} S$ and finailly to the Federal Repository. 
agreement with the MRS host. The proposed agreement, along with the results of an environmental assessment, will be presented to Congress for final approval.

While the Negotiator is working on the agreement, an environmental assessment will be conducted to determine whether the proposed site is suited to host an MRS. Public meetings will be held to solicit citizen input on the scope of the study and to present information on potential impacts of facility construction and operations. If the site is found acceptable for further consideration and Congress approver the host's specified terms, the site will be evaluated further for development as an MRS in its environmental impact statement and safety analysis report, which will be submitted to the Nuclear Regulatory Commission for review and approval.

\section{Design and Construction of an MRS}

The MRS facility will be relatively simple to design, construct, operate, and later dismantle. Engineers and scientists will base the design on safe and proven technologies and on the experience of others with similar facilities either in operation or under construction. The MRS will not perform any atomic, chemical, or high- . energy operations that would have the potential to explode and spread radioactive materials off site. Nor will any of the fuel-handling operations change the chemical or physical characteristics of the spent fuel.

Preliminary MRS designs call for several low-rise buildings to support facility operations. The facilities would be located above ground on 400 to 600 acres of land. Design plans for the MRS will be finalized after a site is demonstrated suitable. The MRS will receive used fuel in heavy, thick-walled, metal shipping containers from commercial nuclear power plants, transfer the used fuel to MRS specially designed storage structures (as necessary), and store the used fuel until it is loaded into shipping containers and shipped to a repository for permanent disposal. These operations will be carried out in accordance with written procedures approved by the Nuclear Regulatory Commission.

Any necessary transfers of used fuel between the shipping containers and the MRS storage containers will be performed inside a specially designed fuel handling building. Protective steel and concrete walls will be included in the building to minimize radiation exposure to workers and the public. The fuel will be handled using remotely operated equipment.

The MRS will be required to meet strict safety standards established and enforced by the Nuclear Regulatory Commission. Facility operations will be closely monitored to ensure the health and safety of the workers and the public. After its mission is completed, the MRS will be decommissioned and dismantled, and all radioactive materials will be removed so that the site can be released for unrestricted use.
For more information, please write: OCRWM Information Center

Post Office Box 44375

Washington, D.C. 20026

or call: 1-800-225-NWPA (or call 488-5513 in Washington, D.C.)

Published by the U.S. Department of Energy Ofrice of Civilian Radioactive Waste Management (OCRWM)

Please recycle. Augusi isyz 

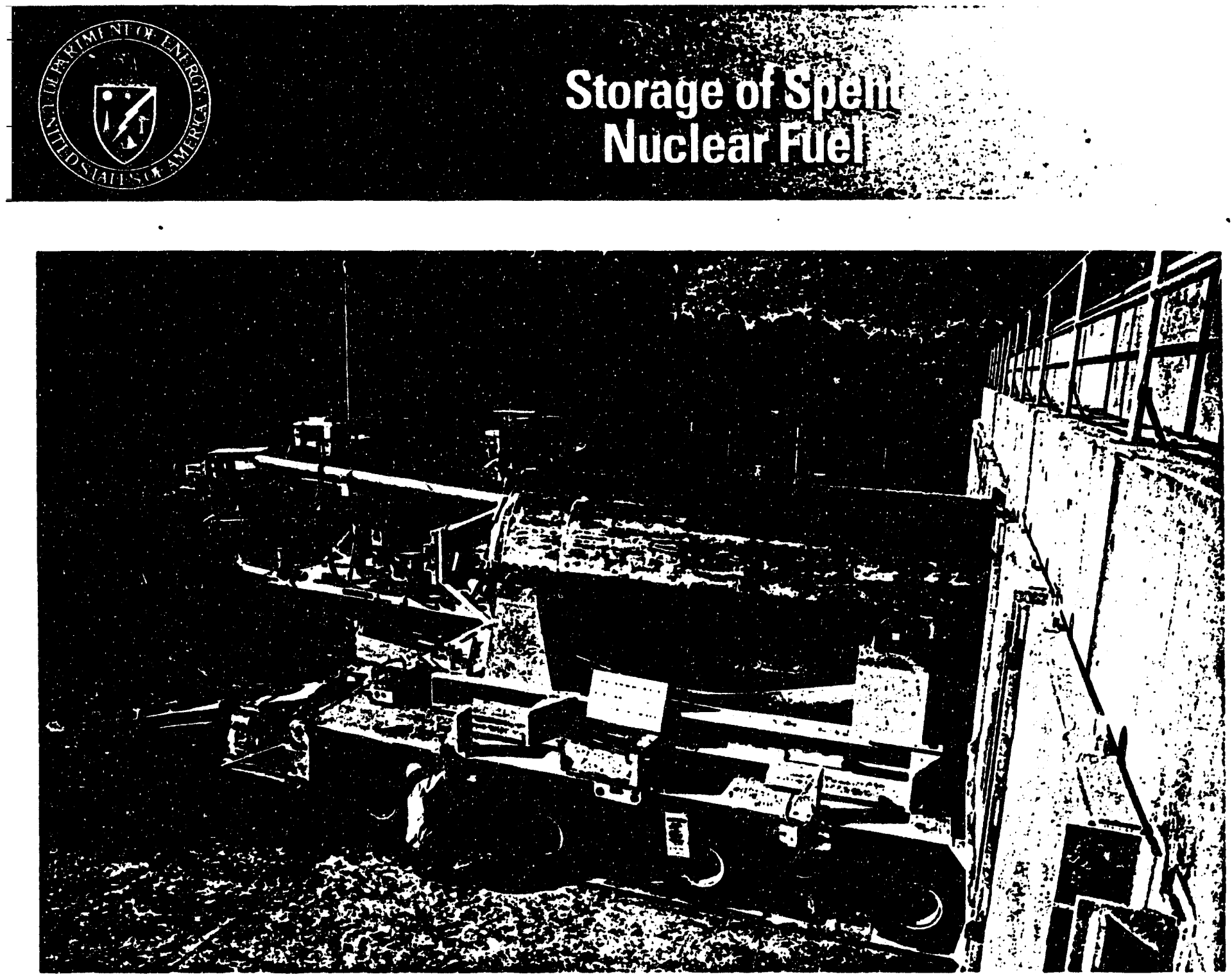

Loading of spent nuclear fuel into a concrete storage module from shielded transfer cask at Duke Power's dry storage facility.

Nuclear waste is material that either contains a radioactive substance or has been contaminated by radioactive elements and is no longer useful. It includes waste products from nuclear processes, such as mining uranium ore, fissioning of uranium in commercial nuclear power plants, processing defense materials, and preparing nuclear isotopes for use in medical applications. It also includes used protective clothing and containers that once held nuclear material.

In 1983 Congress enacted the Nuclear Waste Policy Act (NWPA), which outlines a comprehensive plan for the safe disposal of spent nuclear fuel and other forms of high-level nuclear waste. It also includes development of a mined, geologic repository for longterm disposal of all forms of highlevel radioactive wastes. An amendment enacted in 1987 authorizes the development of a temporary, aboveground storage facility called a Monitored Retrievable Storage (MRS) facility. The MRS will store a limited amount of "spent" or "used" nuclear fuel from commercial nuclear power plants, a solid form of radioactive waste.

To produce electricity, nuclear power plants use solid, ceramic fuel pellets made of uranium. Tremendous amounts of energy are stored in the centers of uranium atoms. When these atoms split, highly radioactive fission products are generated along with the large amounts of heat that make steam to turn turbine generators. The rockhard fuel pellets are encased in strong metal rods. After three or four years in an operating nuclear reactor, the energy remaining inside the pellets is no longer efficient enough to produce usable heat and the pellets have become highly radioactive. These pellets and the surrounding rods must be isolated from the human environment for long periods of time, on the order of thousands of years. Until a permanent repository is in operation, spent fuel will continue to be stored in above-ground facilities such as the ones shown. The MRS will build upon 


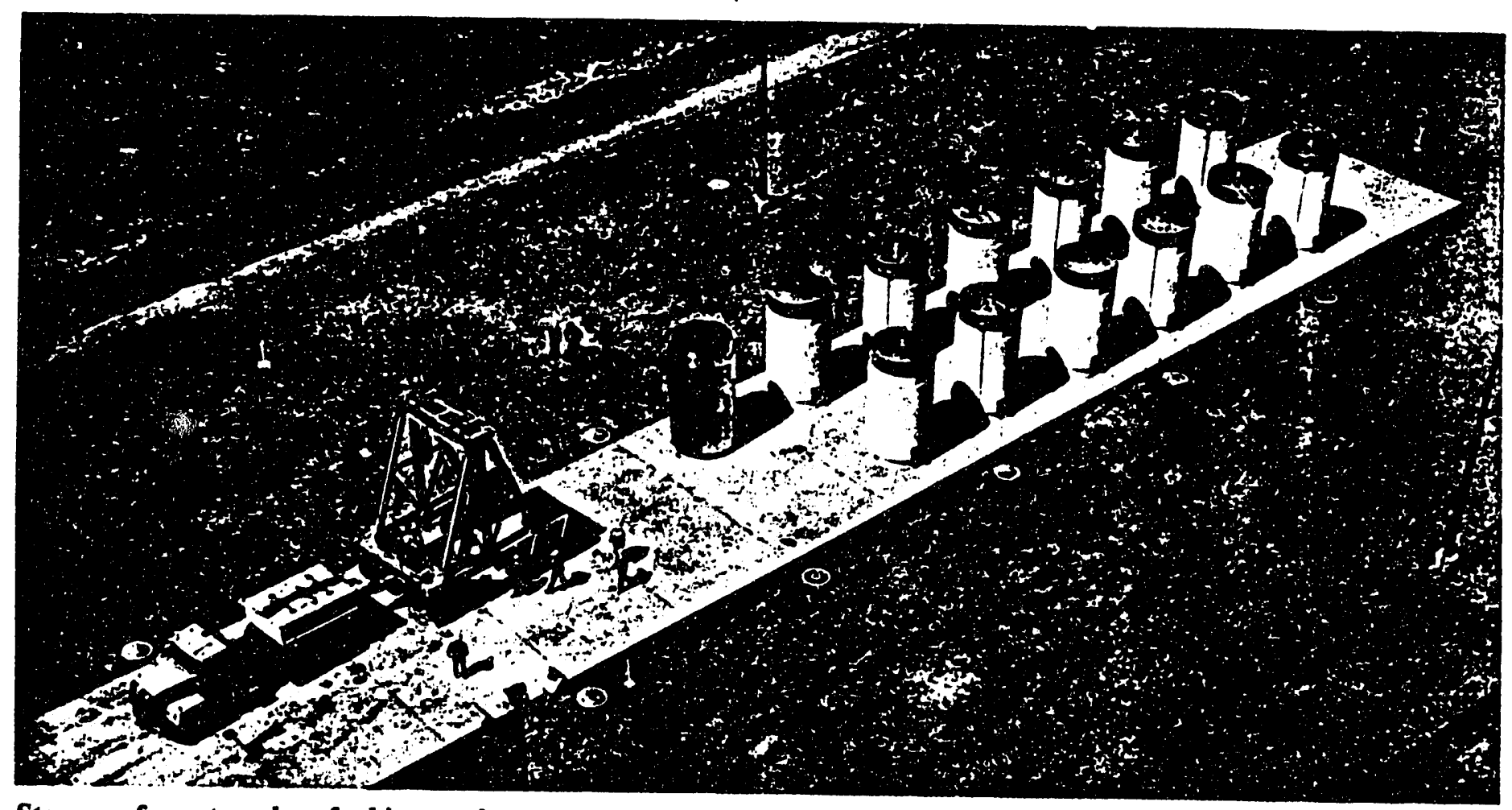

Storage of spent nuclear fuel in metal storage containers at Virginia Power's dry storage facility.

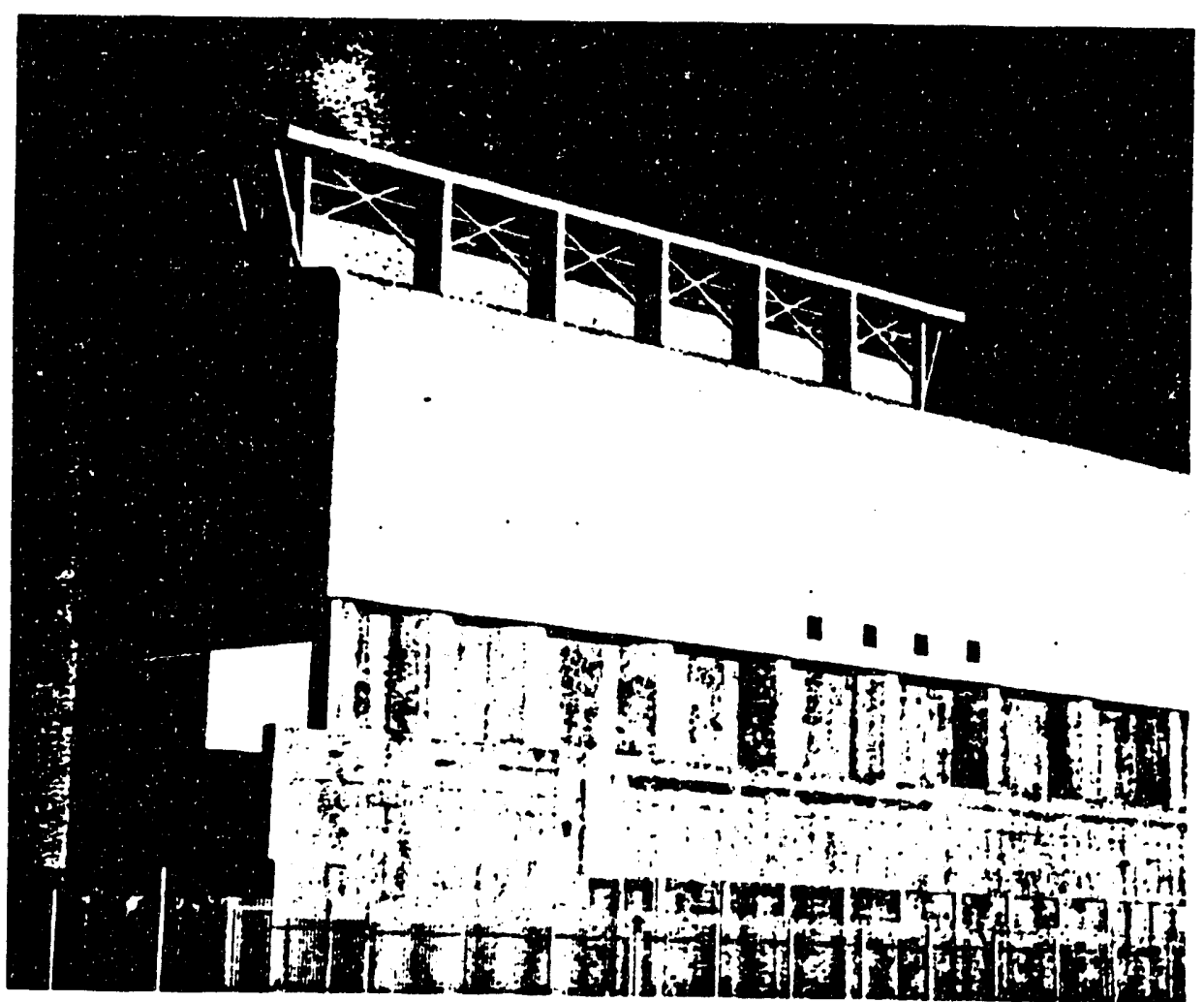

A modular vault dry storage facility operated by the Public Service Company of Colorado built to hold spent nuclear fuel. storage technologies already in operation and demonstrated to be safe.

The U.S. Department of Energy (DOE) is responsible for the Nation's Civilian Radioactive Waste Management System. Within DOE, the Office of Civilian Radioactive Waste Management (OCRWM) is charged with executing policy and managing the program to safely dispose of used nuclear fuel and other forms of high-level radioactive waste.

\section{For more information, please write: OCRWM Information Center Post Office Box 44375 \\ Washington, D.C. 20026 or call: 1-800-225-NWPA (or call 488-551.3 in Washington, D.C.)}

Published by the U.S. Department of Energy Office of Civilian Radioactive Waste Management (OCRWM)

\section{Please recycle.}

August 1992 


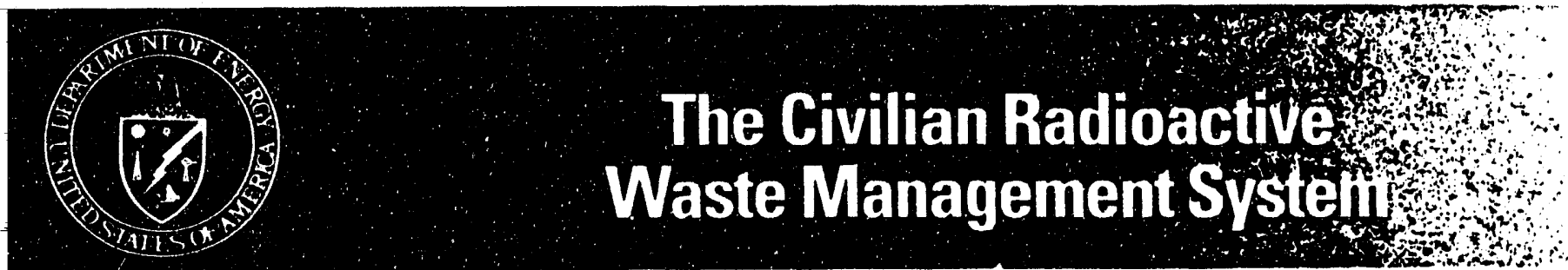

Since the late 1950s, the American people have relied more and more on energy from nuclear reactors. Nuclear reactors now supply a little more than one-fifth of the electricity we use to run our homes, schools, factories, and farms. When the nuclear fuel that generates the electricity in these reactors is "spent" or "used," it is removed from the reactors and stored in specially designed storage pools or, in the case of some older used fuel, placed into heavy, thick-walled metal or concrete structures for storage above ground at the reactor sites. Such storage is proven safe. but is only a temporary solution. Permanent disposal of the used fuel will require isolation from the accessible environment for thousands of years.

Our government is developing a Civilian Radioactive Waste Management System that will provide for the safe disposal of the used fuel and other kinds of high-level radioactive waste.
Those who use electricity produced by nuclear reactors are funding the system for used fuel storage and disposal, not the general taxpayers. These consumers pay a monthly fee, included in their utility bills, which is deposited in the Nuclear Waste Fund established by Congress to fund the program.

The waste management system includes three elements: a mined geologic repository for permanent disposal, a Monitored Retrievable Storage (MRS) facility for temporary above-ground storage, and a transportation system connecting all elements of the Civilian Radioactive Waste Management System. The geologic repository will be developed in an excavated area deep beneath the surface of the earth in a suitable rock formation. Facilities on the surface will accept the used fuel from the MRS and prepare it for disposal in underground mines. To make sure that the repository is safe, scientists will spend many years studying the rocks in and around a proposed site. Both the underground repository and the used-fuel containers will be designed to suit the unique conditions of the site.

In addition, before the repository is built and operated, it will have to be approved and licensed by the Nuclear Regulatory Commission. The scientific studies that will be performed to ensure the safety of the system, including its design and construction, will take many years. In fact, the repository is not expected to be completed unvil early in the next century. When completed, the repository will provide permanent disposal for used fuel from electricity-producing nuclear reactors and high-level waste from national defense activities. The MRS facility, which is to begin operations in 1998, will receive only a limited amount of the solid, used fuel shipped from reactor sites and store it

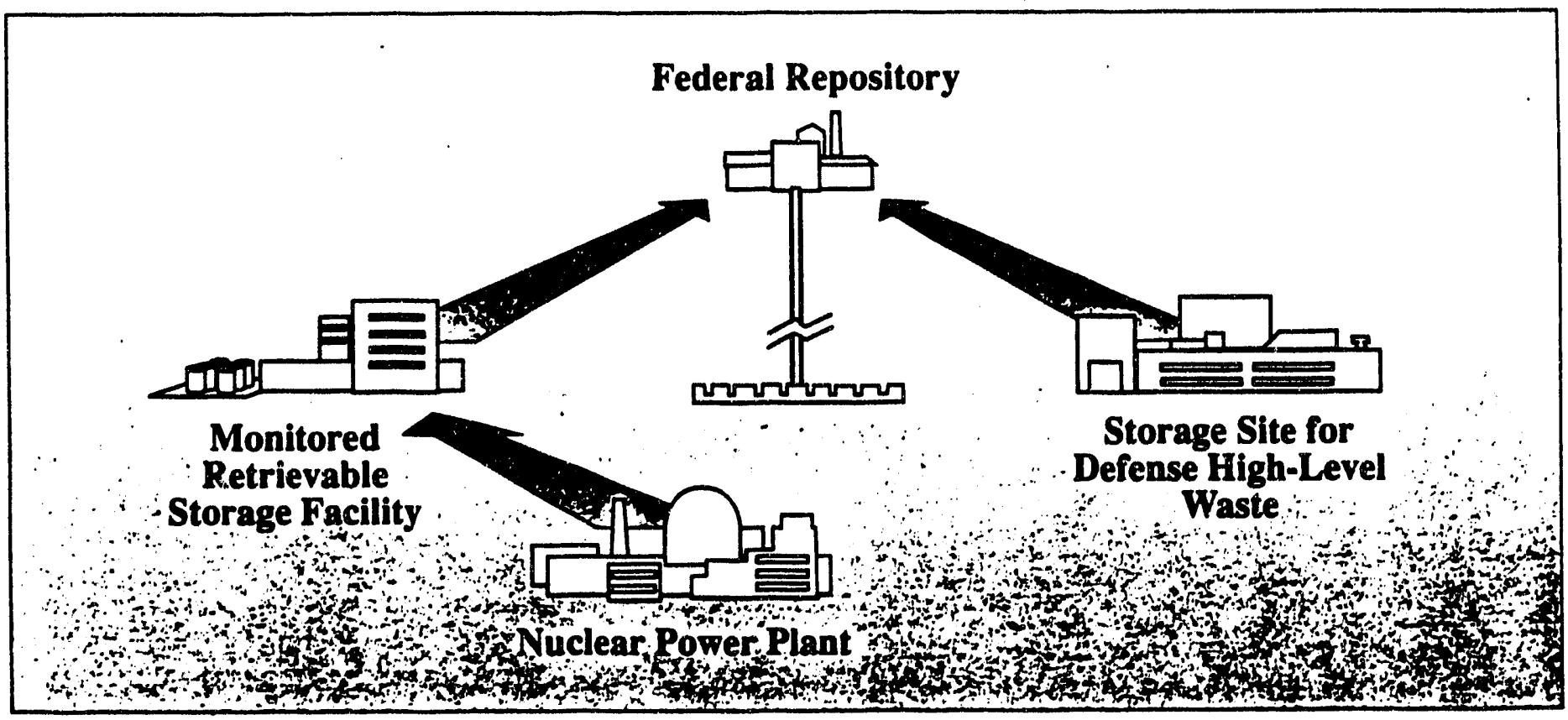

Spent nuciear fuei wiil be shipped from nuciear power piants to the MARS, añd from the MRS to the Federal repository. 
temporarily in specially designed, above-ground structures. When the repository begins operating, the MRS facility will continue to receive used fuel before it is sent to the repository for permanent disposal. The MRS, too, must be licensed by the Nuclear Regulatory Commission. The Nuclear Regulatory Commission establishes requirements and regulations designed to ensure safe operation of licensed nuclear facilities. After its mission is completed, the MRS will be decommissioned and dismantled, and all radioactive materials will be removed so that the site can be released for unrestricted use.

The transportation element of the program will include a system for shipping the used fuel, a fleet of vehicles and railroad cars, metal shipping containers, and support facilities for maintaining the containers. These rugged, heavy, thick-walled containers are designed to completely protect public health and the environment, even in accident situations. The containers must be certified by the Nuclear Regulatory Commission, which requires that such containers be capable of passing a series of rigorous safety tests.
For more information, please write: OCRWM Information Center

Post Office Box 44375

Washington, D.C. 20026 or call: 1-800-225-NWPA (or call 488-5513 in Washington, D.C.)

Published by the U.S. Department of Energy Office of Civilian Radioactive Waste Management (OCRWM)

Please recycle.

August 1992 

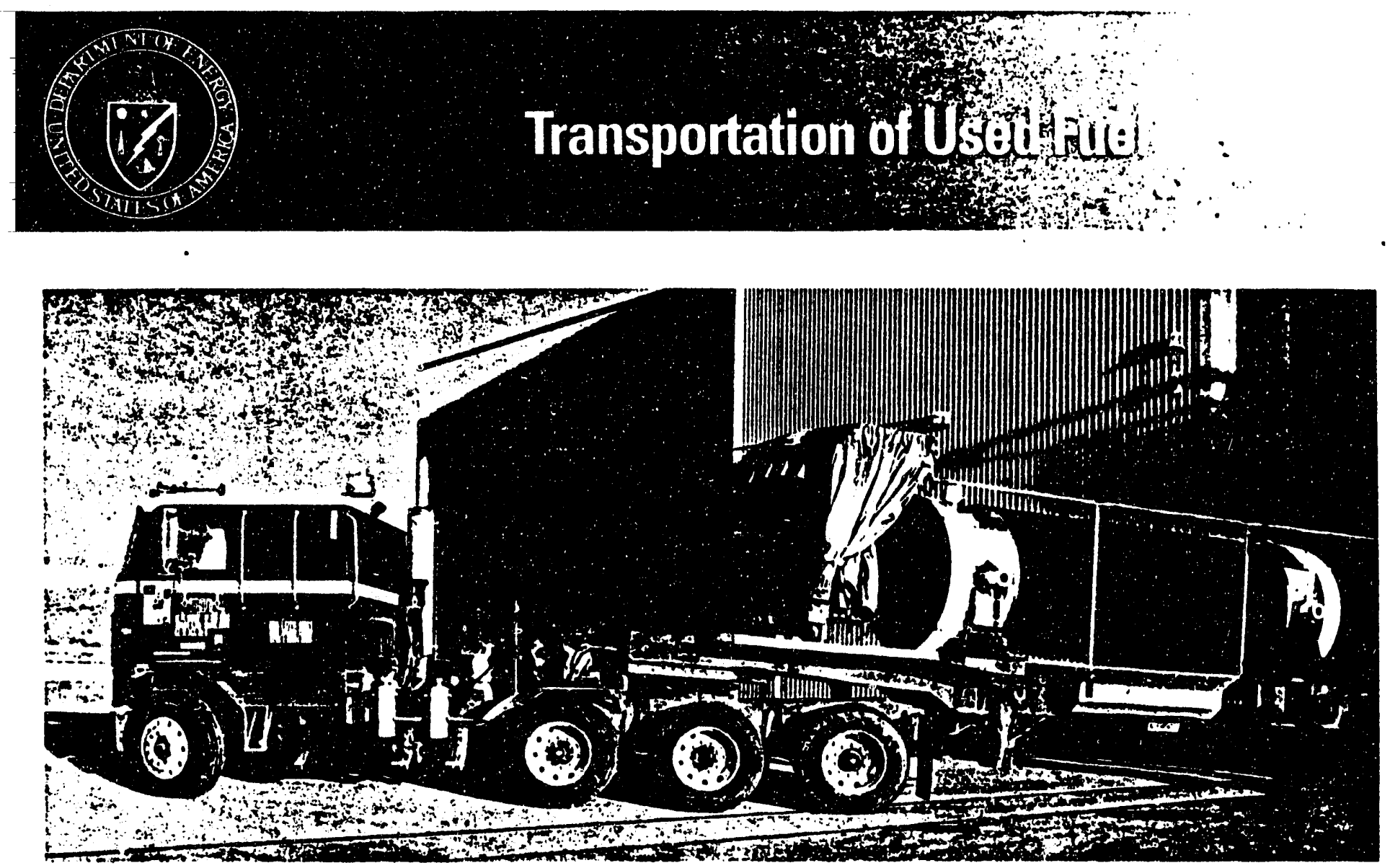

Over the last 25 years, more than 2,500 shipments of used nuclear fuel have been transported safely over America's highways and railroads.

A safe, dependable transportation system is the crucial link in both the proposed operation of a temporary Monitored Retrievable Storage facility and a permanent geologic repository for the disposal of spent (used) nuclear fuel. The amended Nuclear Waste Policy Act requires the Department of Energy (DOE) to accept, transport, and dispose of used nuclear fuel.

Over the last 25 years, more than 2,500 shipments of used nuclear fuel have been transported safely over America's highways and railroads. During this time, an exemplary safety record has been established with no fatalities, injuries, or environmental damage caused by the radioactive nature of the cargo.

\section{Several factors have contributed to} this success story. The used fuel is a solid, rock-hard material enclosed in metal tubes and shipped dry in rugged containers. These containers are heavy, sealed, thick-walled, metal structures that safely confine the used nuclear fuel. These specially engineered containers are designed to keep their radioactive cargo from being released into the environment.

Each shipping container is designed to maintain its integrity under routine transportation conditions and during severe accidents. The containers must ensure radiological safety even after being subjected to the Nuclear Regulatory Commission's (NRC) hypothetical accident conditions, which include:

- A 30-foot free fall onto an unyielding surface

- A puncture test allowing the container to free-fall 40 inches onto a steel rod

- A 30-minute, all-engulfing fire

- An 8-hour immersion in $\mathbf{5 0}$ feet of water.
While the NRC is responsible for approving container design, the U.S. Department of Transportation (DOT) has established regulations for loading, unloading, and handling shipping containers; labeling containers and placarding transport vehicles for purposes of identification; driver training and certification; and highway routing.

Transportation routes will be planned and shipping containers designed with the safety of the public and the environment as the number one consideration. Containers are built with materials that provide structural strength and protect the public from radiation exposures.

Because there is a chance that an accident involving a radioactive shipment could occur, emergency response plans are in place to handle any situation that could arise. The key to effective emergency response is quality training and preparation. 


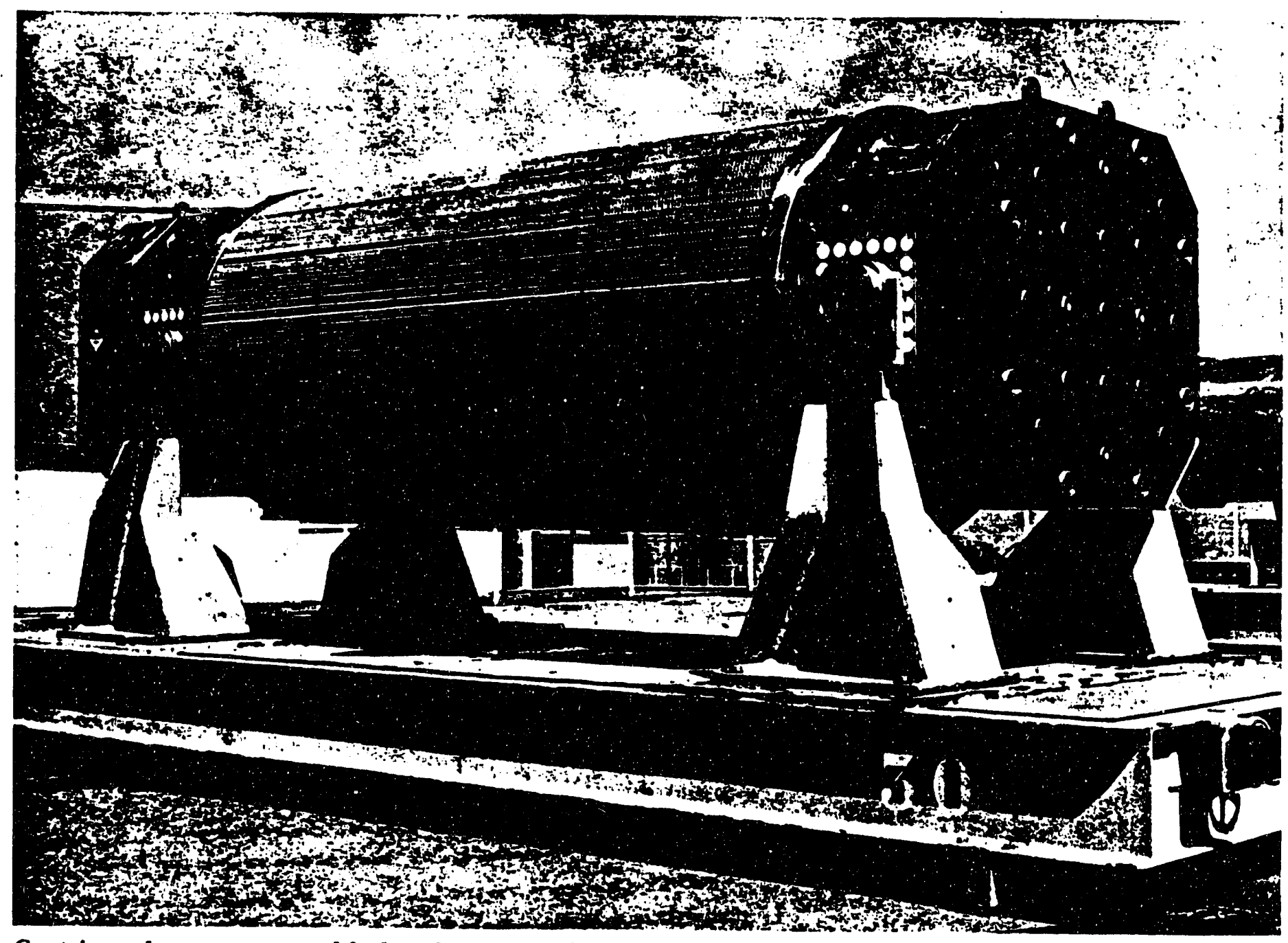

Containers that transport used fuel are heavy, sealed, thick-walled, metal structures which safely confine the used fuel.

Therefore, the DOE will provide assistance for training of State, Tribal, and local governments in the development of emergency response and preparedness plans because States, local govemments and Indian tribes have primary responsibility at the accident scene to protect life, property, and the environment.

All shipments will travel along DOTauthorized preferred interstate routes or rail routes. A state-of-the-art tracking device will link the truck or train with the communications center to allow instantaneous feedback in case of an accident or hazardous weather conditions that could affect safety.

As the number of shipments increases, spent fuel will continue to be moved safely across our nation's highways and railroads. To maintain the program's exemplary safety record, DOE will improve container design and emergency response capabilities and will strengthen the lines of communications among all parties.
For more information, please write: OCRWM Information Center

Post Office Box 44375

Washington, D.C. 20026

or call: 1-800-225-NWPA

(or call 488-5513 in Washington, D.C.)

Published by the U.S. Department of Energy Office of Civilian Radioactive Waste Management (OCRWM) 


\section{INTRODUCTION}

The Monitored Retrievable Storage (MRS) facility will temporarily store a limited amount of spent (used) nuclear fuel in engineered, above-ground storage structures. The purpose of this document is to provide a brief overview of spent fuel storage modes currently licensed, as well as those under development.

A number of different storage technologies have been approved by the Nuclear Regulatory Commission (NRC) and are now being used at nuclear plants throughout the United States. The majority of spent nuclear fuel is stored in stainless steel-lined pools of water at individual reactor sites (wet storage). Several utilities have provided additional spent fuel storage capacity in "passive" dry storage systems. These dry storage modes are described as "passive" because no mechanical equipment is necessary to accomplish the required cooling of the fuel. The fuel stored in these "passive" systems is older fuel that has been allowed to cool in a spent fuel pool for at least five years after being removed from the reactor. Most of the radiation emitted by the spent fuel is effectively absorbed and shielded by the structures surrounding the fuel such that safe radiation levels are always maintained (below regulatory requirements) in the surrounding environment. Dry storage modes approved by the NRC to date include: metal storage casks, horizontal concrete modular storage, vertical concrete storage casks, and modular vault dry storage. A proposed cask design currently undergoing review by the NRC is the transportable storage cask which is designed for both transport and storage.

The selection of the optimum storage technologies for the MRS facility will be based on an evaluation of a number of different criteria. The overriding factor in the selection of any storage technology will be its safety. Other major criteria which impact the final design are: (1) licensability, (2) design maturity, (3) operational experience, (4) environmental impact, (5) socioeconomic impact, (6) flexibility, and (7) cost. Storage of spent fuel at the MRS facility will have to satisfy all NRC requirements. In satisfying all these diverse requirements, the MRS facility may include more than one storage mode rather than a single one. The following pages briefly describe the individual storage modes under consideration for the MRS facility. 


\section{WET (IN-POOL) STORAGE}

Extensive experience with wet (in-pool) spent fuel transfer and storage operations has been gained over the past 35 years at power reactors and research facilities worldwide. It is a mature technology which is very well understood. The NRC Waste Confidence Decision, published in the Federal Register, affirmed the confidence of in-pool storage of irradiated fuel for up to 30 years following reactor shutdown.

Wet storage facilities are generally rectangular-shaped concrete pools with a stainless steel lining. The fuel assemblies are stored individually in a vertical orientation in metal racks which maintain the spacing between assemblies and allow for retrieval of the fuel. Chemically treated water surrounding the assemblies provides heat removal, biological shielding and controls on the nuclear chain reaction. Approximately 28 feet of water is required above the tops of the fuel assemblies. Spent fuel pool cooling, cleanup and ventilation systems are required to be operating at all times (active system). A trolley, which spans the width of the pool, supports a fuel handling "bridge" with a telescoping fuel mast that is used to move fuel assemblies to different locations in the pool. At one end of the spent fuel pool, a separate cask-handling area is used to load and unload fuel to/from a transport cask. A heavy-duty overhead crane provides the capability to lift the transport cask to/from a truck or rail carrier in the fuel receiving area, and is physically prevented from traveling directly over the stored spent fuel.

A single, large storage pool could be constructed for the MRS facility. It would be approximately 200 feet in length and 130 feet wide with 3 different sizes of high-density spent fuel racks. The pool could be designated as a dual operations facility, with "right" and "left" operating areas. Two fuel-handling cranes (bridges) would be used with dual center rails mounted on a beam running the entire length of the pool. On one end of the pool, two separate cask handling areas would be provided to allow for cask transfer operations (loading and unloading). Each cask-handling area would be provided with its own heavy-duty crane for lifting operations. Several equipment rooms in a building adjacent to the pool would provide the necessary water cooling and purification. 


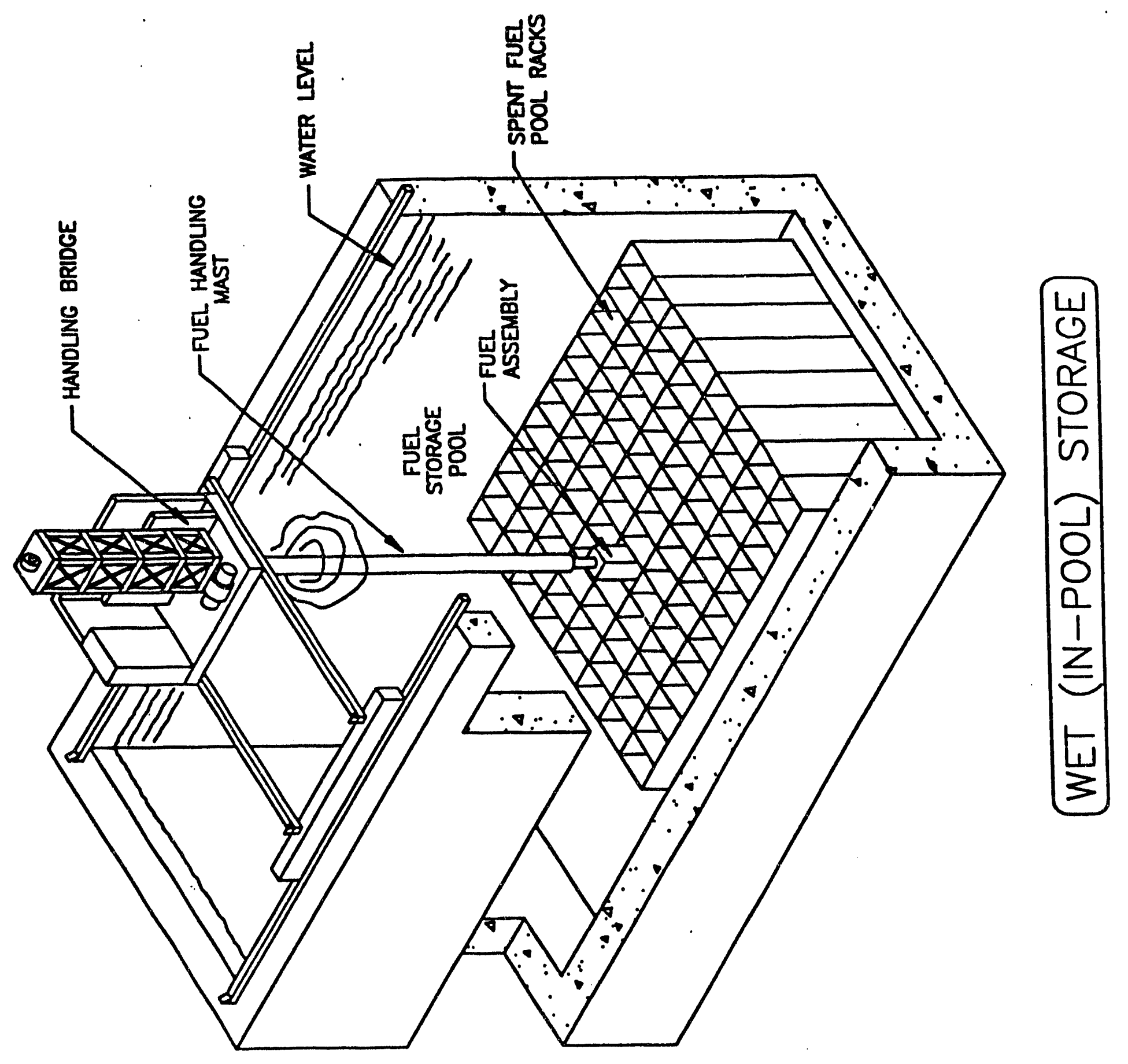




\section{METAL STORAGE CASK}

The storage of spent fuel in metal casks is the most mature of all the dry storage technologies in the United States. This technology has been demonstrated in several programs by utilities and by the DOE since 1984. The NRC has approved four metal casks for storage under a general license at any nuclear power station.

Metal storage casks are large, thick-walled, cylindrical vessels equipped with an internal grid structure called a "fuel basket" that is designed to hold the spent fuel assemblies in place. A typical metal storage cask is approximately 16 feet long and 8 feet in diameter, weighing 100 to 125 tons when fully loaded. The thick wall of the cask body provides shielding for gamma radiation emitted by the fuel, and is usually made of forged steel, cast iron, or lead and stainless steel materials. In addition, the cask body is normally surrounded by a layer of neutron-absorbing material. The external surface of the cask may be either smooth or finned to enhance cooling. Two to four trunnions (that act as lifting handles) are generally located on each end of the cask to provide lifting and rotation capabilities. The inside cavity of the cask contains the "fuel basket" which is capable of storing 21 - 74 fuel assemblies, depending on the cask design, the type of used fuel, and the amount of time since the fuel was discharged from the reactor. In order to provide secure containment of the radioactive material, metal storage casks are closed and sealed with one or more lids.

Since these metal storage casks are not licensed for transportation, the spent fuel assemblies would be loaded into the DOE's transport casks at the individual reactor pools. At the MRS facility, the casks would be offloaded from the transport vehicle at a Fuel Handling/Transfer facility with thick concrete walls where the individual spent fuel assemblies would be transferred from the transport cask to a metal storage cask using remotely operated equipment. This transfer operation could occur under either dry or wet conditions, although dry transfer in a controlled environment is more likely since both the fuel arriving at the MRS facility and the fuel stored in the metal storage casks will be in a dry environment. After loading the metal storage cask with fuel, the cask would be sealed, and backfilled with a nonreactive gas (such as nitrogen) to prevent possible degradation of the fuel from chemical reactions with oxygen. The cask would then be loaded on a vehicle for movement to a concrete storage pad located a short distance from the Fuel Handling/Transfer facility. The metal casks would be stored on a concrete storage pad in a predetermined pattern. 


\section{HORIZONTAL CONCKETE MODULAR STORAGE}

In this dry storag: concept, the spent fuel is transferred into a stainless-steel storage canister, which is then sealed and backfilled with a nonreactive gas (i.e., nitrogen or helium) and inserted into a bunker-like concrete module in a storage field. Two independent spent fuel storage installations (ISFSI's) that use horizontal concrete modules have been licensed and constructed $b_{y}$ utilities, with at least two more being planned. The operational facilities, at H.B. Robinson and Ciconee Nuclear stations, both use a storage system where the canisters are inserted horizontally into a concrete storage module. The licensed storage capacities are 7 spent fuel assemtlies per canister at H.B. Robinson, and 24 assemblies per canister at Oconee.

The major corm:ponents of this system are a stainless-steel canister, a shielded transfer cask, a special-purpose trailer, and a concrete horizontal storage module. The canister includes an internal basket for holding the fuel assemblies in place. The transfer cask provides shielding from radiation and protects the canister as it is moved onsite from the Fuel Handling/Trans'ar facility to the storage field. The special-purpose trailer is used to carry the loaded transfer cask and provides the precise alignment required to mate the transfer cask with the docking port of the concrete storage module. A hydraulic system is then used to push the canister into the cavity inside the concrete module. The concrete module has walls which are 3-feet thick and provide radiation shielding and protection for the canister. To complete the installation, a 2-inch-thick steel door is lowered and welded in place to cover the docking port on the storage module.

The loading of the multiple-element storage canister could take place at the utilities' spent fuel pouls or at the MRS facility. If the canister was loaded at the reactor site, then a customized transport cask would be necessary in order to transport the loaded canister to the MRS site. Alternately, the canister could be loaded at a Fuel Handling/Transfer facility at the MRS site using remotely operated equipment. After either receiving the canister following shipment from the reactor site or loading directly at the MRS facility, the sealed canister is inserted inte a shielded transfer cask at the Fuel Handling/Transfer facility to travel the short distance to the MRS storage field. The canister is subsequently inserted into a horizontal concrete module in the storage field (one canister per module). The thickwalled concrete modules provide both radiation shielding and heat removal. Air channels in the concrete module provide a means of transferring the heat from the spent fuel storage canister. The number of concrete siorage modules can he increased as needed in order to meet additional storage requirements. 


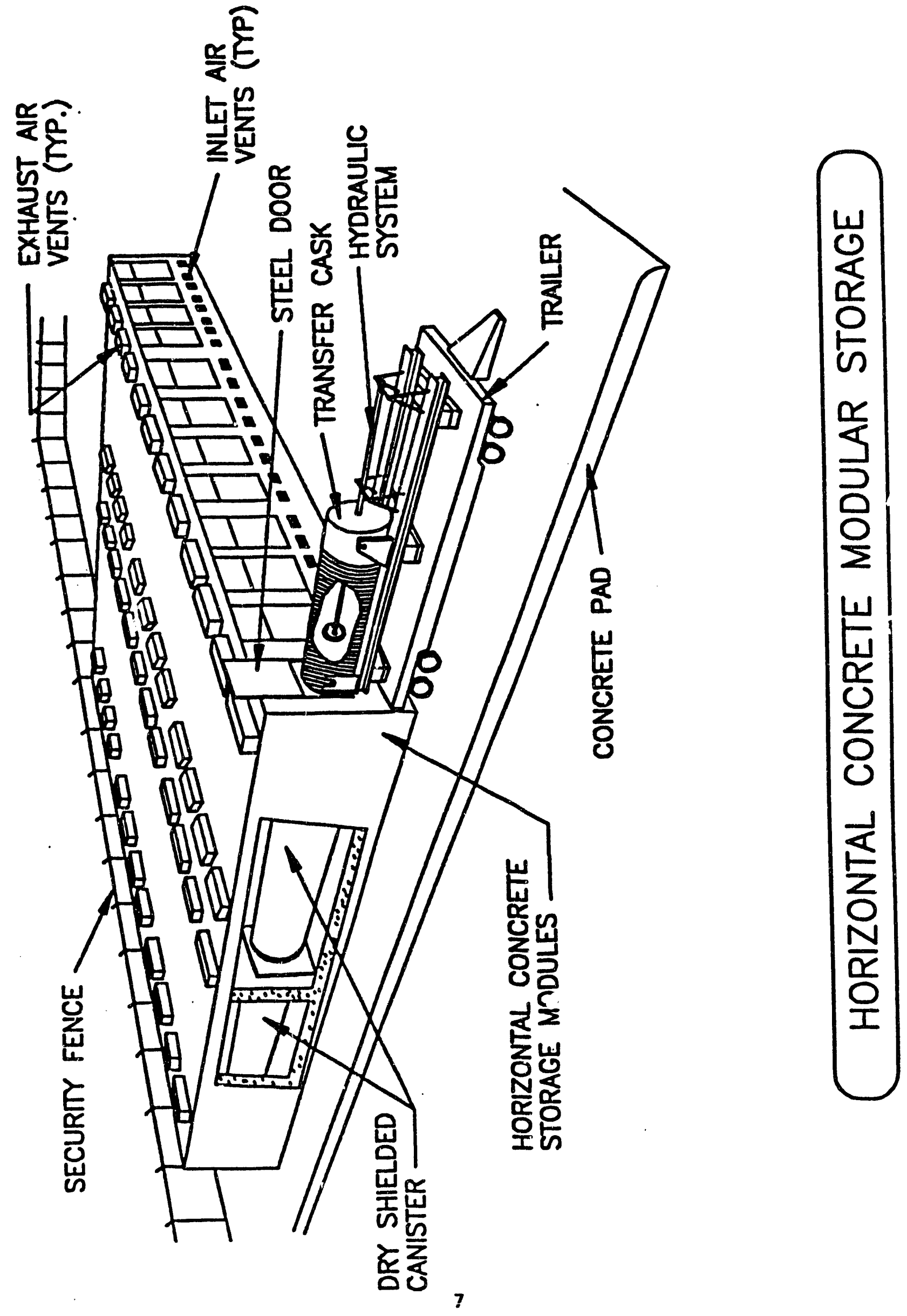




\section{VERTICAL CONCRETE STORAGE CASK}

This concept employs dry storage in the form of cylindrical reinforced concrete casks, similar to the metal dry stcrage casks. The thick concrete walls provide radiation shielding and passive heat removal. Concrete casks differ from the concrete modular system in that each cask is independent (i.e. free-standing), whereas concrete modules are generally built together (side-by-side and back-to-back). Two variations of concrete cask designs have been studied: (1) ventilated, and (2) unventilated. These casks have not been commercially tested in the United States, although a ventilated cask design has been successfully demonstrated in cooperative spent fuel storage tests at a DOE laboratory. This ventilated cask design has also recently received approval from the NRC. In addition, two utilities have made plans to use this design to increase their onsite spent fuel storage capacity.

The NRC-approved ventilated concrete cask is approximately 17.5 feet high and 11 feet in outside diameter, weighing approximately 132.5 tons when fully loaded. The sealed interior canister houses the spent fuel assemblies, with a nominal capacity of $24-52$ assemblies depending on the type of reactor. A steel liner separates the outer concrete shell and the interior multi-assembly sealed canister. The ventilated concrete cask provides additional heat transfer capabilities to limit the peak concrete and fuel assembly temperatures by providing inlet and outlet air flow ducts in the concrete shell near the top and bottom of the cask. Ventilated casks dissipate more heat than unventilated casks and therefore, they can generally store more spent fuel assemblies per cask.

The spent fuel would arrive at the MRS facility in the DOE's transport casks from the utilities' reactor sites. At the Fuel Handling/Transfer facility, spent fuel assemblies from the transport cask would be unloaded and transferred into the interior canister of a large concrete storage cask. An automated, remotely operated transfer room is the most likely candidate currently being considered for this transfer operation. The automated transfer room would consist of a thick-walled, totally enclosed, concrete structure that provides a shielded area in which radioactive materials can be handled safely by remotely operated equipment in a dry ventilated air environment. After loading all assemblies into the fuel storage canister inside the concrete storage cask, the canister would be sealed and backfilled with a nonreactive gas. The concrete cask would then be moved to the MRS facility storage field and placed vertically on a concrete pad. 

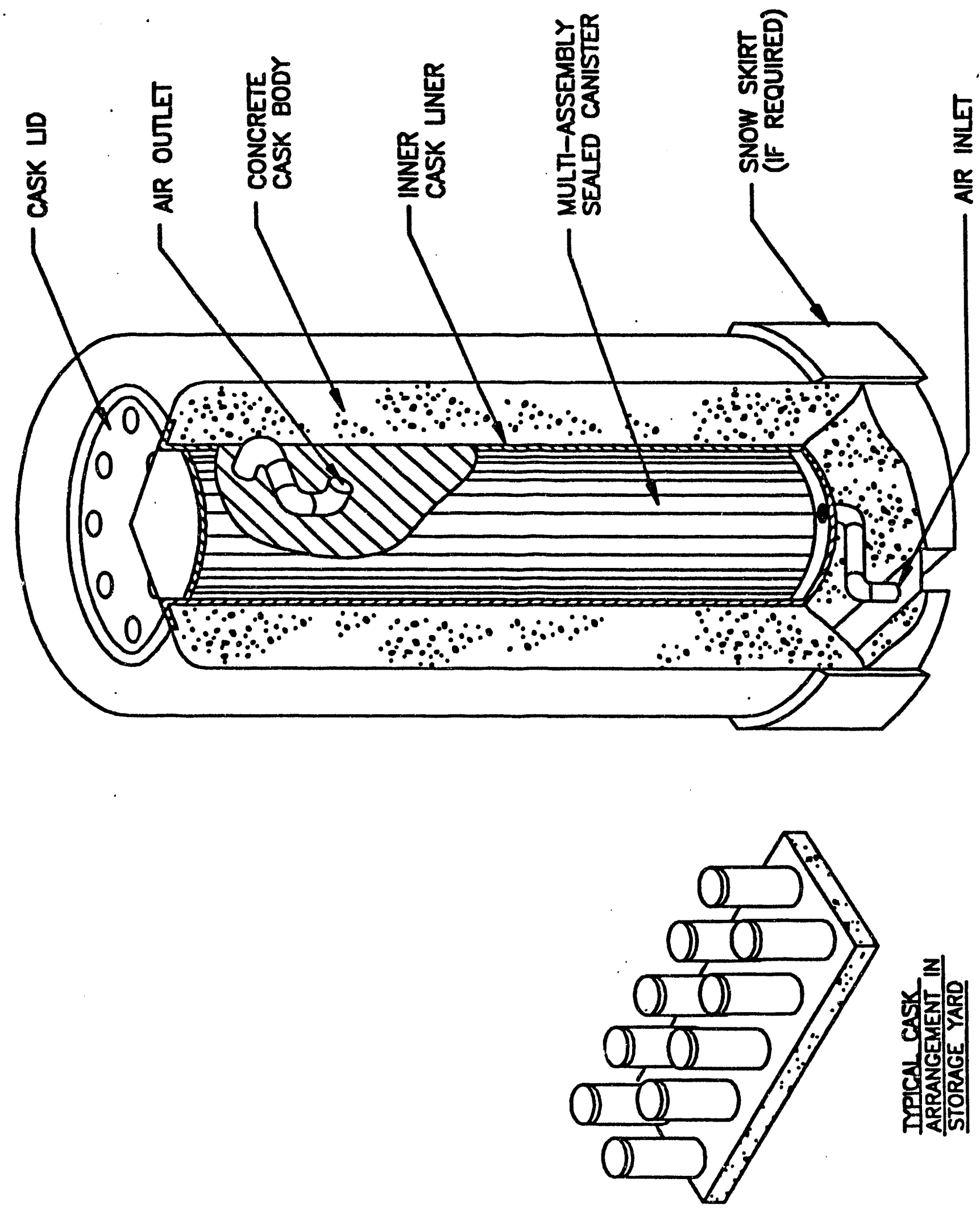

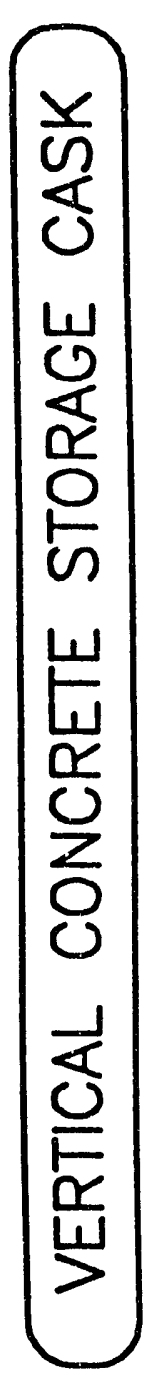




\section{MODULAR VAULT DRY STORAGE (MVDS)}

A modular vault dry spent fuel transfer and storage concept would involve unloading the DOE transport casks at the MRS facility, and transferring the fuel assemblies by means of a fuel handling machine to storage tubes or canisters contained within a concrete vault. The storage tubes would be filled with a nonreactive gas (such as nitrogen or helium) to prevent corrosion. The MVDS concept incorporates both spent fuel transfer (from incoming transportation casks) and storage functions within the same building. Increases in storage capacity could be achieved by expanding the number of concrete vaults.

A generic design for such a system has been approved by the NRC. An MVDS system based on this design has been chosen by Public Service Company of Colorado for the onsite storage of graphite spent fuel from its Fort St. Vrain high temperature gas-cooled reactor. Construction of the Independent Spent Fuel Storage Installation (ISFSI) at Fort St. Vrain was completed in September 1991.

In the NRC-approved MVDS design, the modular concrete vaults consist of metal fuel tubes vertically arrayed in a concrete structure. Each tube stores a single spent fuel assembly, with each module capable of storing from 100 to 200 assemblies (depending on the type of spent fuel). The fuel storage tubes, made of carbon steel, are shielded and protected on all sides by the surrounding concrete structure. The walls of the concrete structures have built-in cooling channels to promote cooling by air flow around the fuel tubes. Each fuel tube penetrates an upper shield concrete structure and opens into the floor of a fuel-handling bay. Additional shielding protection is provided by a removable shield plug at the opening of each storage tube. Above the array of fuel tubes, a shielded fuel-handling machine moves on a rail trolley spanning the width of the fuel storage area. In order to load a fuel assembly into any given fuel tube in the storage vault, the fuel-handling machine positions itself over the transport cask in the cask receiving area and vertically withdraws an assembly into its shielded upper section. The fuel-handling machine then moves on the trolley system to the desired fuel storage tube location and vertically lowers the assembly into the fuel storage tube. Finally, the shield plug is placed over the loaded storage location to provide both physical and biological protection. The cask receiving area is designed to accommodate both standard truck and rail shipping casks.

The proposed MVDS design for application at an MRS facility would be arranged in the form of two arrays of 40 modules each in a "back-to-back" orientation with a central HeadEnd Facility in the center for the entry and exit of fuel transport casks. The receiving bay could also contain two fuel handling machines to provide for increased reliability and allow two casks to be unloaded simultaneously. 


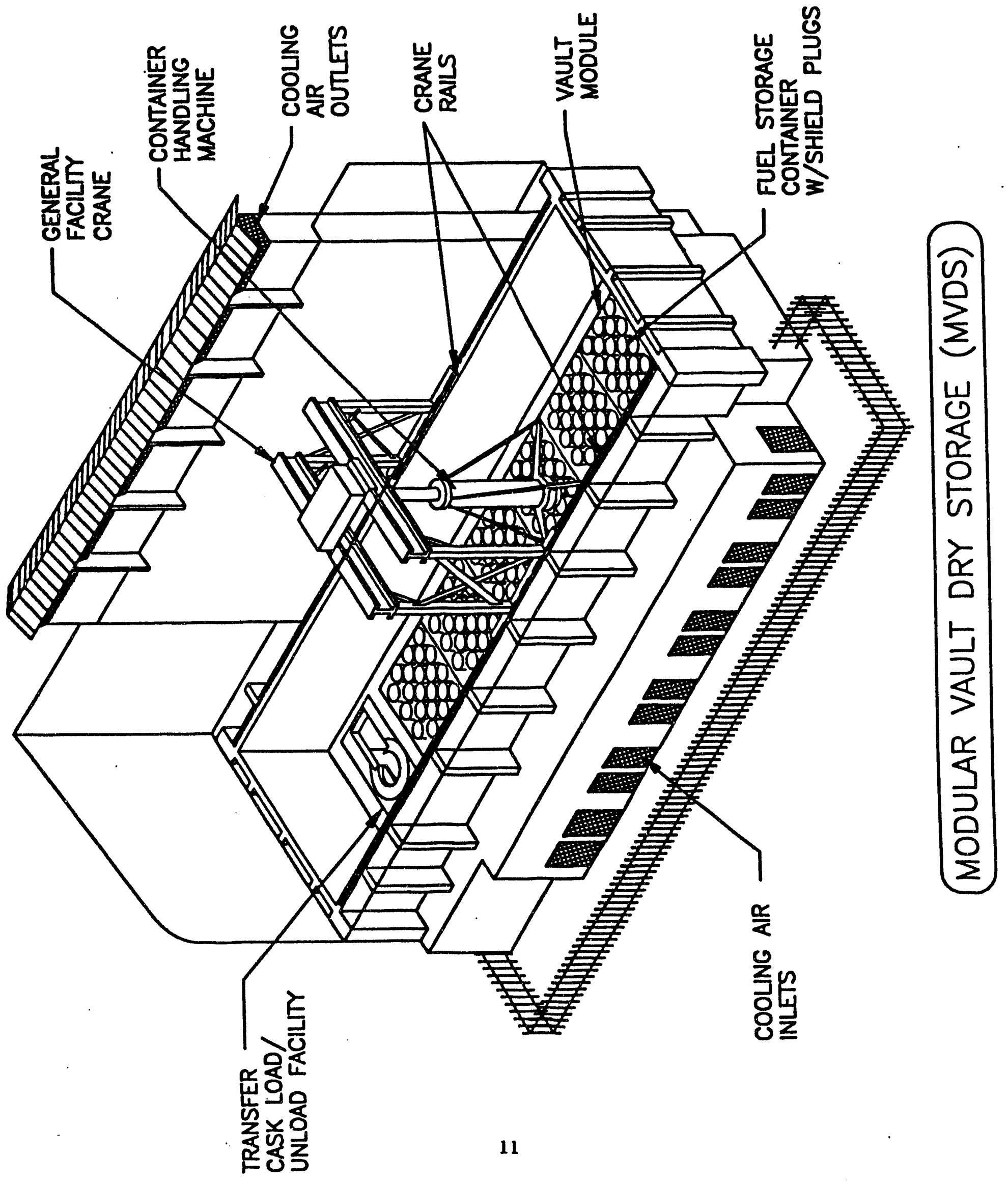




\section{TRANSPORTABLE STORAGE CASK}

Transportable storage casks are similar to metal dry storage casks that have been demonstrated and licensed for storage-only purposes. They are often referred to as dualpurpose casks because approval is being sought from the NRC to license these casks for both transport and storage. The benefit of this proposed cask design is that spent fuel assemblies can be loaded at reactor sites and transported directly to a spent fuel storage area at the MRS facility with no need to routinely open the cask to handle the fuel. In this configuration, the MRS facility would essentially act as a parking area for the casks before they are shipped to the geologic repository for permanent disposal.

Dual-purpose casks are heavy, metal cylindrical vessels equipped with an internal fuel basket for holding the spent fuel assemblies. One vendor is currently marketing its dual-purpose cask design, but the NRC is still in the process of reviewing their license submittal for transportation. Approval has been granted to use this cask design for storage only. NRC requirements concerning severe accident conditions during transport result in the need to use materials with better structural properties than the storage-only design. The proposed dual-purpose cask design being reviewed by the NRC is approximately 16 feet long and 8 feet in diameter, weighing 116 to 124 tons when fully loaded. The internal cavity of the cask contains fuel baskets that can store $26-52$ fuel assemblies, depending on the type of spent fuel. The cask body provides shielding for gamma radiation emitted by the fuel, and is surrounded by a layer of neutron-absorbing material. In order to provide secure containment and shielding of the radioactive material, the cask is closed and sealed with two lids.

These casks are designed for rail transport because of weight considerations. However, many of the older reactors in the United States do not have rail access, or are otherwise unable to handle either the size or weight of these casks in their spent fuel pool(s). If this storage technology was used exclusively for the nuclear waste management system, then some type of fuel transfer system would need to be built at the MRS facility or at those reactor sites unable to accommodate the dual-purpose casks. This system would be designed to transfer the spent fuel assemblies from small transport casks into the larger dual-purpose casks. For those reactor sites that are able to handle the dual-purpose casks, the fuel could be loaded directly in the pool (wet transfer). After loading the cask, it would be transferred in a horizontal position onto a rail vehicle for transport to the MRS facility where it would be stored directly on a concrete storage pad. Although the dual-purpose cask would not require the fuel to be routinely unloaded and handled at the MRS facility, a separate fuel handling system would be necessary in order to provide recovery for possible damage to the spent fuel assemblies or casks incurred in transit to or while in storage at the MRS facility. 


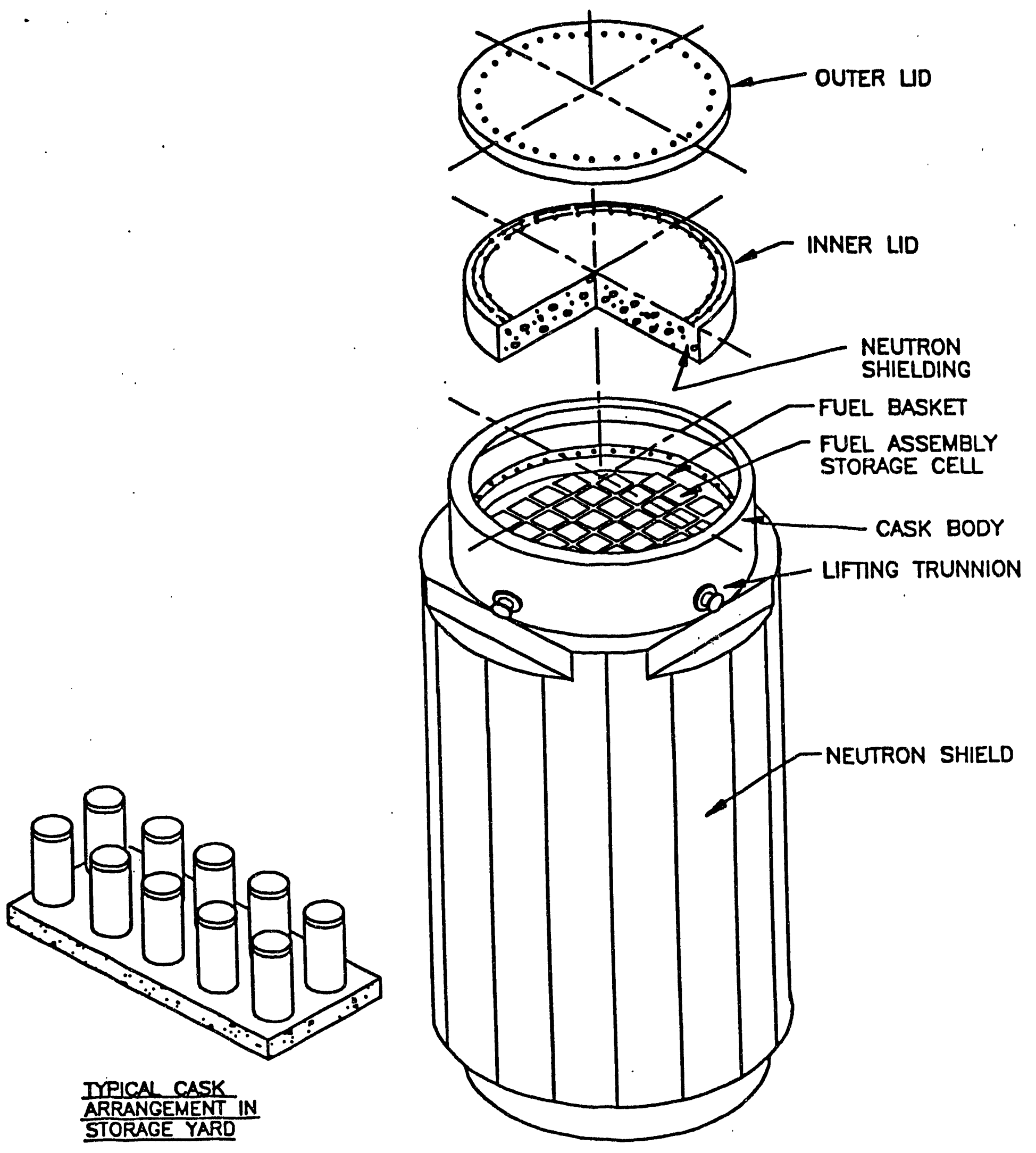

TRANSPORTABLE STORAGE CASK 


\section{Dry Cask Storage Fact Sheet}

Location - Surry Power Station, Surry, Virginia (Across the James River From Jamestown)

Start-UP Date - Licensed by U.S. NRC in July 1986

- First Cask Loaded and Placed In Storage in Deœmber 1986

\section{Cask Designs}

Cost - Approximately $\$ 1,200,000$ per Cask

Manufacturers - General Nuclear Systems, Inc., (Germany)

- Westinghouse Electric Corporation (Japan and Florida)

- Nuclear Assurance Corporation (Japan and Spain)

Dimensions

- 16 Feet High

- 8 Feet in Diameter

- Weigh 120 Tons When Loaded With Fuel

Capacities - 21-33 Fuel Assemblies per Cask

Composition - Two Designs Use Nodular Cast Iron

- One Uses High Strength Steel

- One Uses Lead and Stainless Steel

\section{Storage Facility}

Pad Dimensions

- 230 Feet Long

- 30 Feet Wide

- 3 Feet Thick (Reinforced Concrete)

Capacity - Each Pad Will Hold 28 Casks

- The Facility License Provides for Three Pads

Facility and Casks

Evaluated For

- Temperature Extremes $\left(-20^{\circ} \mathrm{F}\right.$ to $\left.115^{\circ} \mathrm{F}\right)$

- Extreme Wind (105 mph)

- Tornado Missiles (e.g. Car at $126 \mathrm{mph}$ )

- Flood (Not Possible)

- Fires at Power Station

- Snow and Ice

- Loss of Electrical Power

- Loss of Cask Radiation Shielding

- Lightning Strikes

- Tornados (300 mph)

- Earthquake (Cask Does Not Tip Over)

- Gas Pipeline Explosion

- Aircraft Crashes

- Solar Heating

- Cask Seal Leakage

- Cask Drop

Virginia Power Is the First Utility in the United States to Use Dry Storage for Spent Nuclear Fuel 

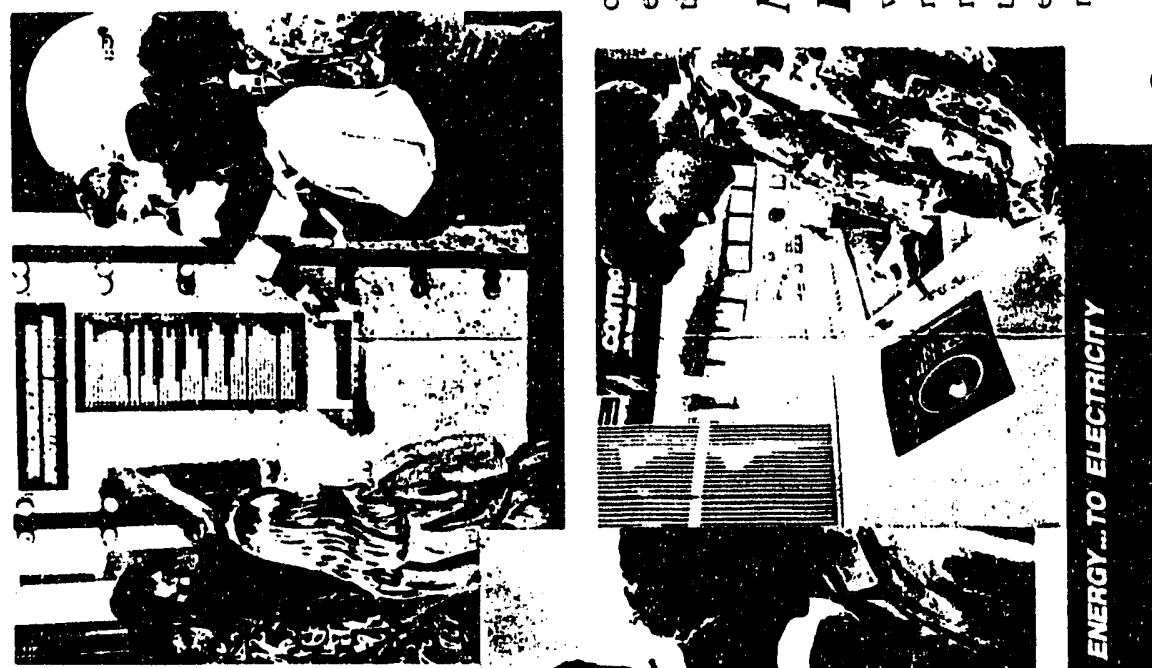

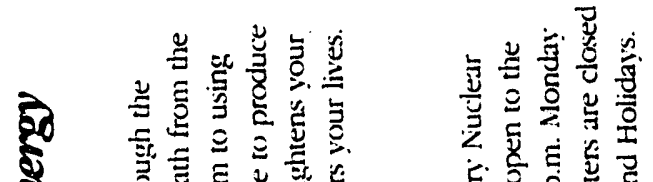

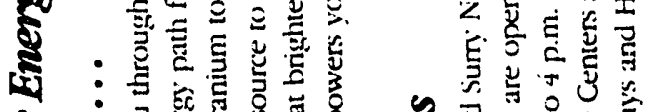
है दे

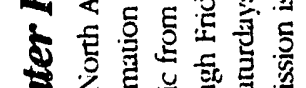

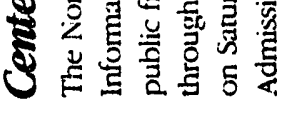
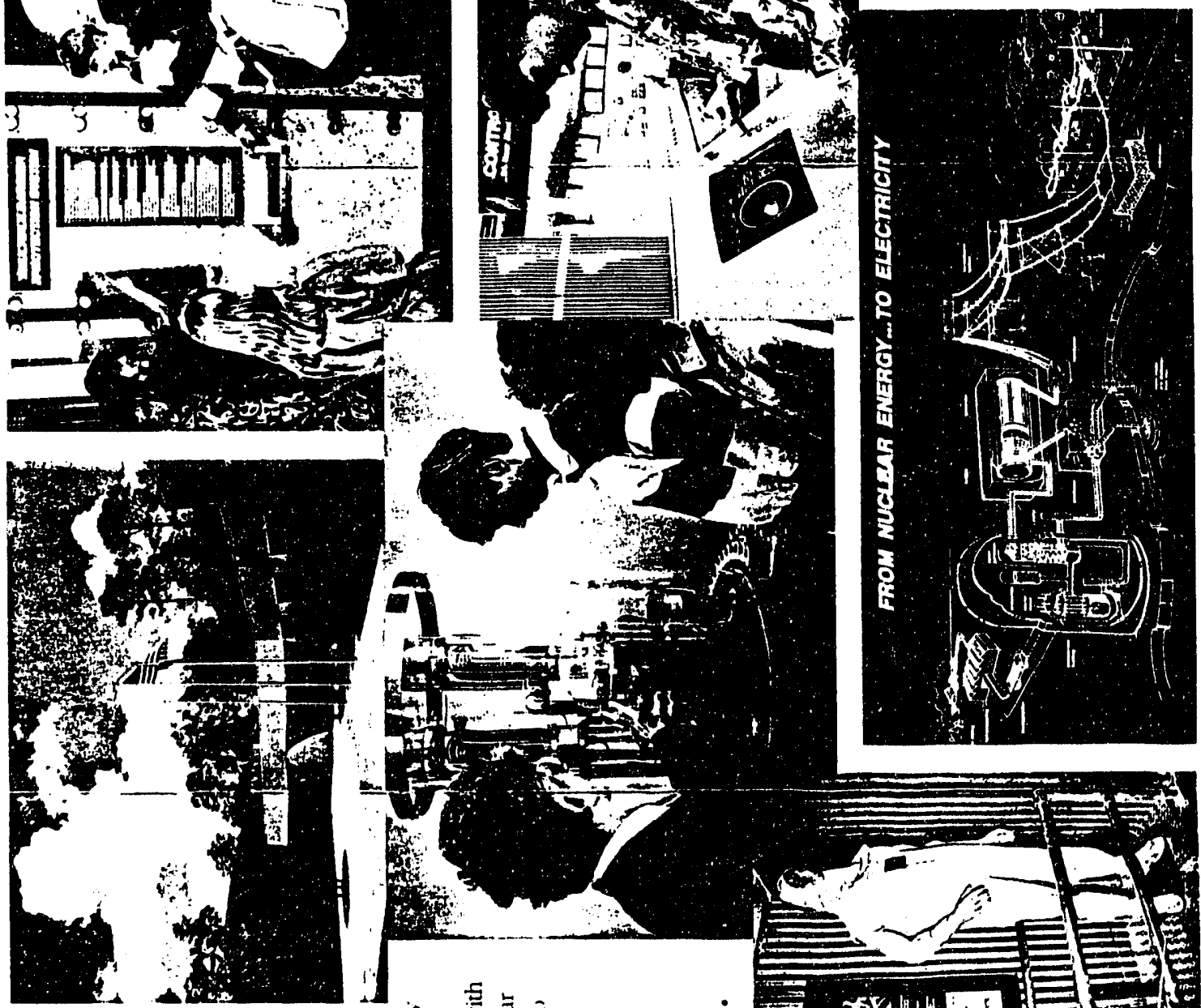

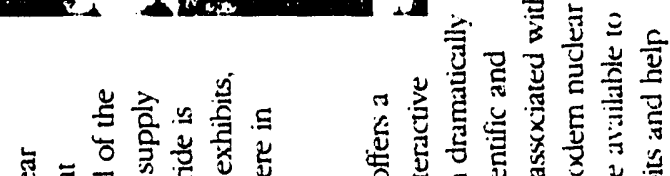
चั

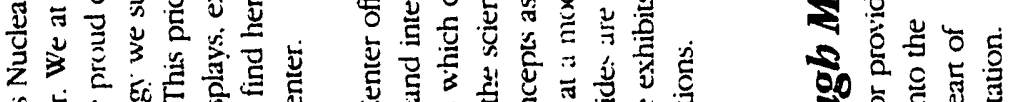

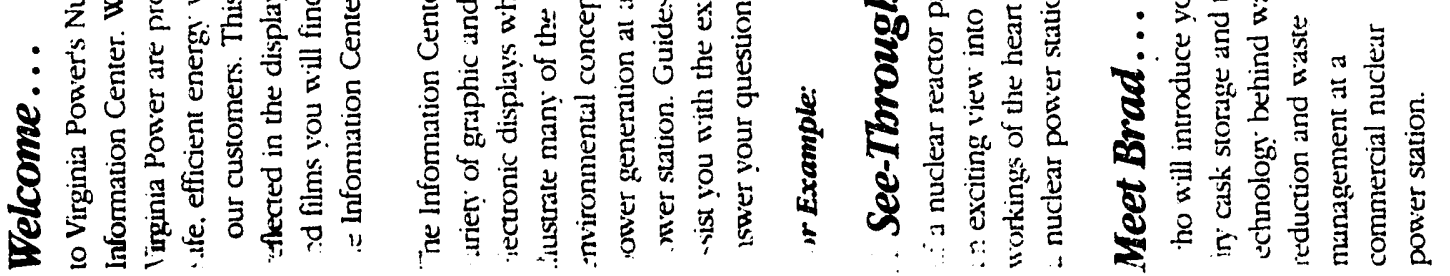



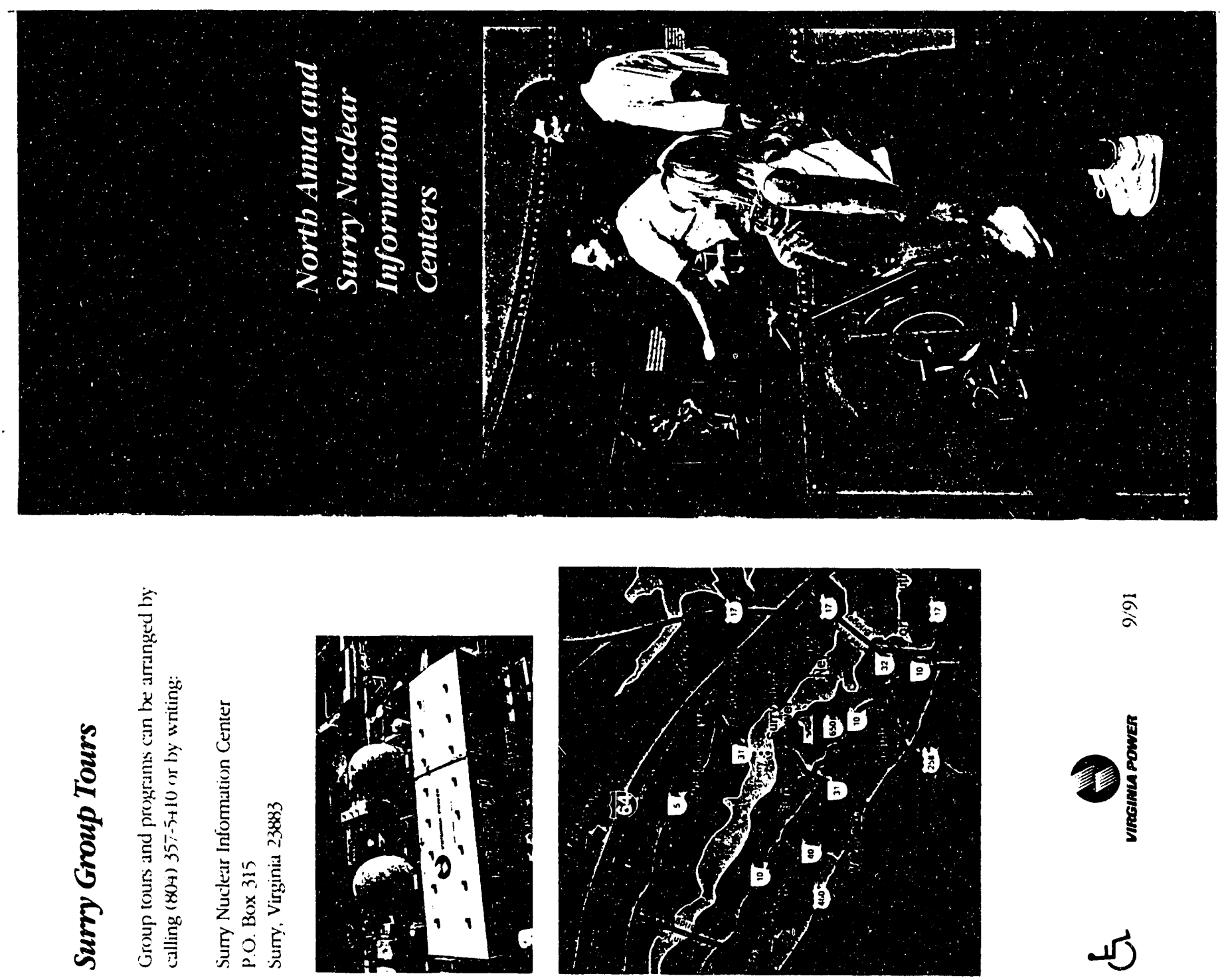

ลั

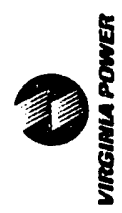
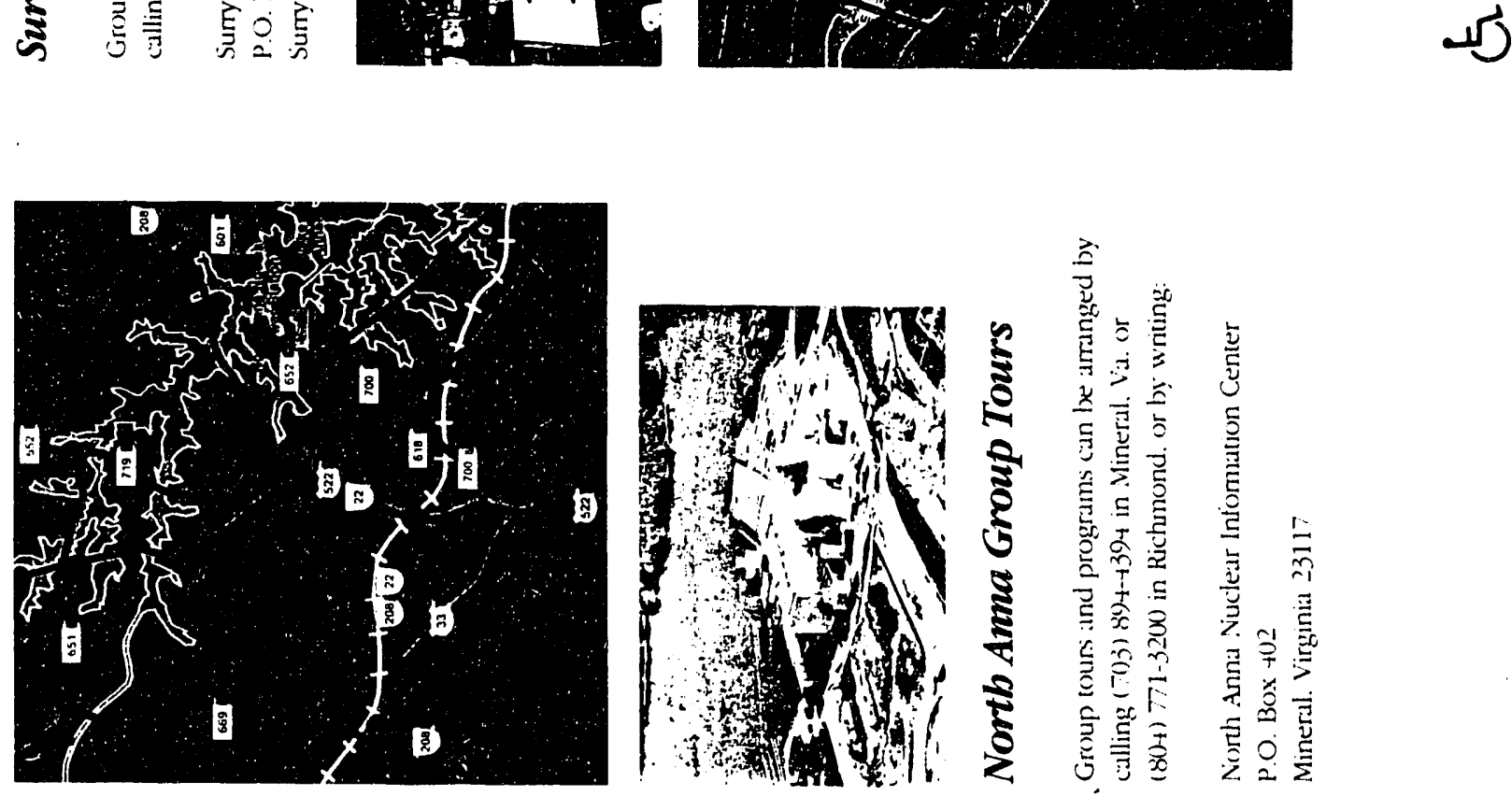


\begin{abstract}
A National Environmental Issue
Ten companies have combined their technical and management expertise to address a critical envirommental issue: the safe, permanent disposal of the nation's spent nuclear fuel and highlevel radioactive waste. Led by TRW, these companies comprise the Department of Energy's management and operating (M\&O) team for the U.S. Civilian Radiuactive Waste Management System.
\end{abstract}

This system will consist of three major components: a transportation system to move the waste safely to storage and disposal sites; a inonitored retrievable storage (MRS) facility for the temporary storage of spent fuel from civilian reaclors; aild a deep geologic repository for the pernanent disposal of spent nuclear fuel and high-level waste. The repository will include "engineered barriers" - man-Inade containers and structures - to isolate the waste from the environument.

Congress has directed the Deparument of Energy (DOE) to study one site, Yucca Mountain in Nevada, to find out whether or not it is suitable for a repository. The site characterization of Yucca Mountain. consisting of geologic, hydrologic, and other scientific studies, is expected to take several years. If at any time the site is found unsuitable, DOE will stop the studies and seek new direction from Congress.

\section{M\&O Contractor}

In 1991, DOE hired TRW to serve as $\mathrm{M} \& \mathrm{O}$ contracior for the progran. The $\mathrm{M} \& \mathrm{O}$ contractor is responsible for integrating the work of others working on the program and for assisting DOE in designing, developing, and implementing the system. The M\&O team consists of:

TRW Environmental Safety Systems

B\&W Fuel Company

Duke Engineering \& Services

E.R. Johunson Associates
- Fluor Daniel

- INTERA

JK Research Associates

Logicon RDA

Morrison Knudsen Corporation

Woodward-Clyde Federal Services

These ten companies are industry leaders. Each is committed to scientific and technical excellence. Each is dedicated to the safe, pernanent disposal of the nation's spent nuclear fuel and high-level radioactive waste.

\section{TRW Environmental Safety Systems}

TRW Envirommental Safety Systems lnc. is a wholly owned subsidiary of TRW lnc., one of the nation's top industrial firms with more than 70,000 employees in 21 countries. TRW ranks among the nation's leaders in the space and defense, automotive, and information systems markets. The company also is active in other markets with a high technology or engineering content.

In the 1950 s, the company becaune systems engineer and tecluical adviser for the U.S. intercontinental ballistic inissile program, among the largest technical programs in the nation's history. TRW was the first company to build a spacecraft, Pioneer 1 , launched in 1958, and since then has produced more than 175 spacecraft. For DOE, TRW designed and operated a facility to separate uranium isutopes. Later, TRW decommissioned this facility and restored the site for unrestricted use. TRW was also the prime contractor for DOE's Naval Oil Shale Reserves Developinent Progran in Colorado and, under separate contracts, developed processes for the clean burning of coal.

TRW is the prime $M \& O$ contractor for the Civilian Radioactive Waste Management Program. Under the direction of DOE, TRW is responsible for systems engineering, design, development, technical direction, management, and operation of the program.

\section{B\&W Fuel Company}

The B\&W Fuel Coinpany brings to the program a long tradition of excellence in the design and fabrication of nuclear reactors, fuel assemblies, and related equipment. Based in Lynchburg, Va. the B\&W Fuel Company supplies products and services primarily to the comunercial nuclear power industry. Products include nuclear fuel, control rods, reactor instrumentation, fuelconsolidation equipment, and shipping and storage containers. Plants operating on fuel supplied by the B\&W Fuel Company have set U.S. records for total generation and world records for capacity factor (a measure of operating efficiency). The company offers a variety of fabrication and inspection services for nuclear power plants.

The B\&W Fuel Company is designing engineered barriers for the geologic repository. The company also heads the $M \& O$ team's training department and supports team efforts in systems engineering, licensing, transportation system development, quality assurance, and the design of an MRS facility.

\section{Duke Engineering \& Services}

Duke Engineering \& Services provides engineering and related services to clients both in the United States and abroad. As a subsidiary of Duke Power Company, DE\&S has access to unsurpassed expertise in siting, designing, building, licensing, operating, and maintaining nuclear facilities. Duke Power ranks as the nation's seventh largest investor-owned utility. Its service area covers some 20,000 square miles of the two Carolinas, and the company's generating capacity exceeds 16 million kilowatts. The Nuclear Regulatory Commission has ranked Duke's Catawba, McGuire, and Oconee Nuclear Stations anong the most efficient in the nation. Duke also was among the first utilities to design, build, and operate a dry-storage facility for spent nuclear fuel. Similar technology may be used at the nation's MRS facility. 
Duke Engineering is designing the MRS facility. DE\&S also provides quality assurance, public outreach, licensing. repository design, and MRS siting support for the program.

\section{E.R. Johnson Associates}

Based near Washington, D.C., E.R. Johnson Associates, Inc. - JAI covers the full range of nuclear technology, from the mining of uranium ore to the disposal of spent nuclear fuel. JAI has developed conceptual designs and cost estimates for nuclear facilities, including fuel fabrication and reprocessing plants, waste-storage facilities, and geologic repositories. The company has analyzed and assessed options for packaging, consolidation, shipment, storage, disposal, and safeguarding of spent nuclear fuel and high-level waste. JAl has also conducted system studies, developed quality assurance programs, audited environmental programs, and assisted in the licensing of nuclear facilities.

\section{$J A I$ is involved in the development of waste-acceptance criteria and data bases, analysis of financial risks, development of shipping containers, selection of spent-fuel storage methods, and systemis analysis.}

\section{Fluor Daniel}

Fluor Daniel ranks among the world's largest engineering and construction firms and for several years has led the nation in new engineering and construction contracts. The company provides a full range of services: engineering, procurement, construction, construction management, and maintenance. Fluor Daniel has been involved in the design of nuclear facilities for more than 40 years and has provided services for more than 40 nuclear units worldwide. These services include engineering, construction, maintenance, and plant modifications. Projects have included uranium enriclunent plants, a plutonium production and recycling facility, a plant for solidifying nuclear waste, reprocessing facilities, research laboratories, and a waste repository.

Fluor Daniel is designing the surface facilities for the geologic repository. The company is also supporting MRS design, quality assurance, systems engineering, and licensing activities.

\section{INTERA}

Founded in 1973, INTERA specializes in the environunental sciences. With an experienced staff of hydrologists, geologists, geochemists, and other scientists and engineers, this Texasbased company provides consulting services to both government and industry. INTERA projects involve various aspects of environmental protection, hazardous-ivaste initigation, and regulatory compliance. Recent work includes site characterization and analysis of proposed hazardous-waste facilities, reclamation of uranium mines, environmental audits of industrial facilities, and remediation of contaminated ground water.

INTERA is involved in performance assessment for the proposed repository. Performance assessment involves developing models and conducting studies to predict how the site will behave under a given set of conditions.

\section{JK Research Associates}

JK Research Associates provides strategic planning, policy development, public involvement, and communications support to govermment agencies, corporations, universities, and laboratories. Associates of the firm have worked in radioactive waste policy development since the 1970s and are widely recognized experts on national and international waste-management policies. JK associates have served on the National Academy of Sciences' Board on Radioactive Waste and Committee on Risk Perception and Comununication, on the Secretary of Energy Advisory Board, and on numerous peer-review and expert panels.

$J K$ provides strategic planning and policy analysis for the $M \& O$ team.

\section{Logicon RDA}

Founded in 1971 as R\&D Associates, RDA has grown to more than 600 employees in offices around the world. In 1983, RDA became a subsidiary of Logicon, Inc., a Los Angeles-based company with more than 3,000 employees. Logicon RDA specializes in hightechnology systems, primarily those with defense applications. The company has conducted research for the Defense Department's nuclear weapons effects progran and has provided engineering support for the developinent of high- energy lasers as part of the Strategic Defense Initiative.

Logicon RDA is playing a lead role in systems engineering and work integration for the program.

\section{Morrison Knudsen Corporation}

From its early involvement in construction, Morrison Knudsen has grown into a major intermational corporation serving the environmental, industrial process, power, transportation, and other markets. MK provides a complete range of engineering, construction, and related services for government agencies and private industry in the United States and abroad. Morrison Knudsen has participated in more than 200 projects involving hazardous or radioactive materials. In the 1980 s, MK supported the first decommissioning of a commercial nuclear power plant in the United States and is currently involved in a second decommissioning.

Morrison Knudsen is leading the design effort for the underground facilities and associated material-handling systems at the repository.

\section{Woodward-Clyde Federal Services}

Woodward-Clyde Federal Services, a subsidiary of the Woodward-Clyde Group, specializes in geotechnical studies, environunental services, and hazardous-waste management. The Engineering New's-Record has consistently ranked the Woodward-Clyde Group among the nation's top 50 design firms. Woodward-Clyde has conducted geotechnical studies for siting dams, landfills, and industrial facilities and has been involved in the cleanup and disposal of hazardous wastes. The company's clients include both private industry and government agencies. Previous work for DOE includes studies to assess possible radioactivewaste sites at various locations in the United States.

For the M\&O team, Woodward-Clyde is heading the site-characterization effort at Yucca Mountain.

For More Information
For more information, please contact
us at TRW Environmental Safety
Systems, 2650 Park Tower Drive,
Suite 800, Vienna, VA 22180.
Telephone: 703.204.8500.




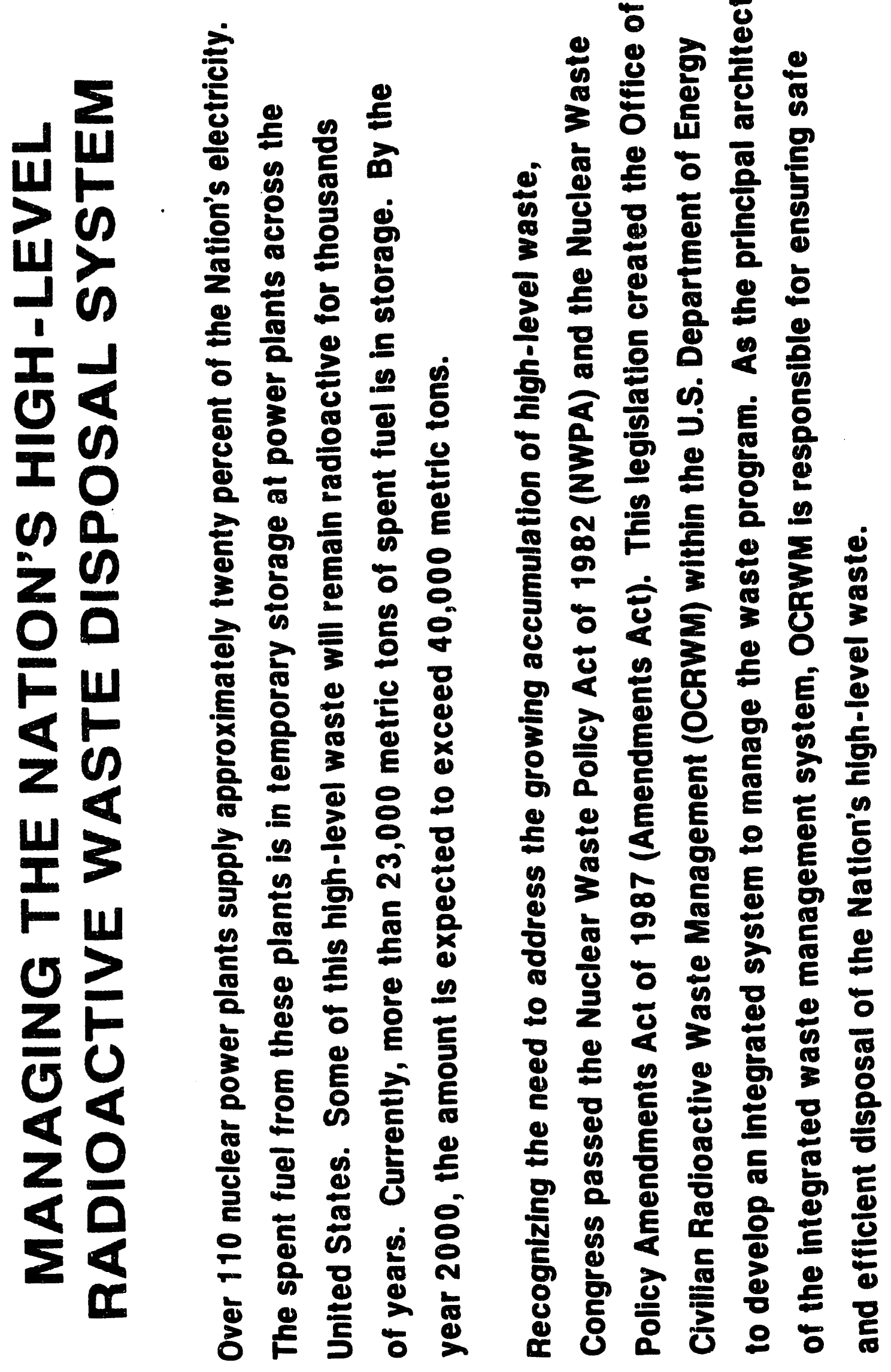



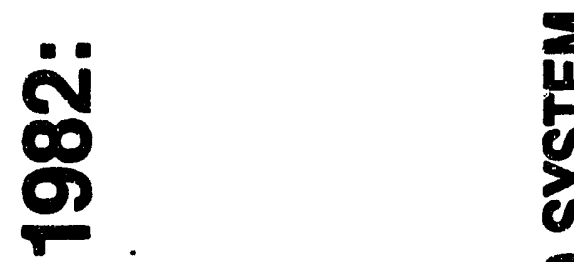

0

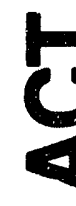

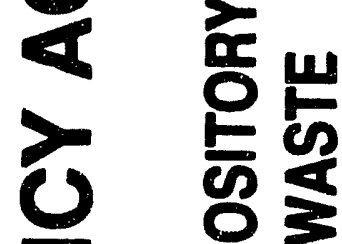

$\rightarrow$ ํㅜㄴ

0 a

a 2 मा

11 क

m $\mu$

de $\frac{14}{4}$

$\geqslant$ 응

a 0 \%

a $20 \frac{0}{20}$

11 से

(1)

$\infty \quad 5 \geqslant$

2

4

$2=$

8 in

ic $\frac{\omega}{\alpha}$

D

2

0

Cs

i1

क I1

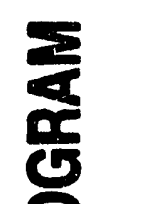

5

II

2

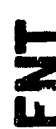

4

IV

in

$\frac{11}{2}$

0

4

0

5

8

2

0

62

2

H

c)

02

$=$

$\sum$ 넘

$\frac{5}{6}$

$\frac{1}{6}$

2

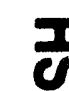

क ㄴ

ळ

$\infty$

$\sum$

CP

8

-

0 


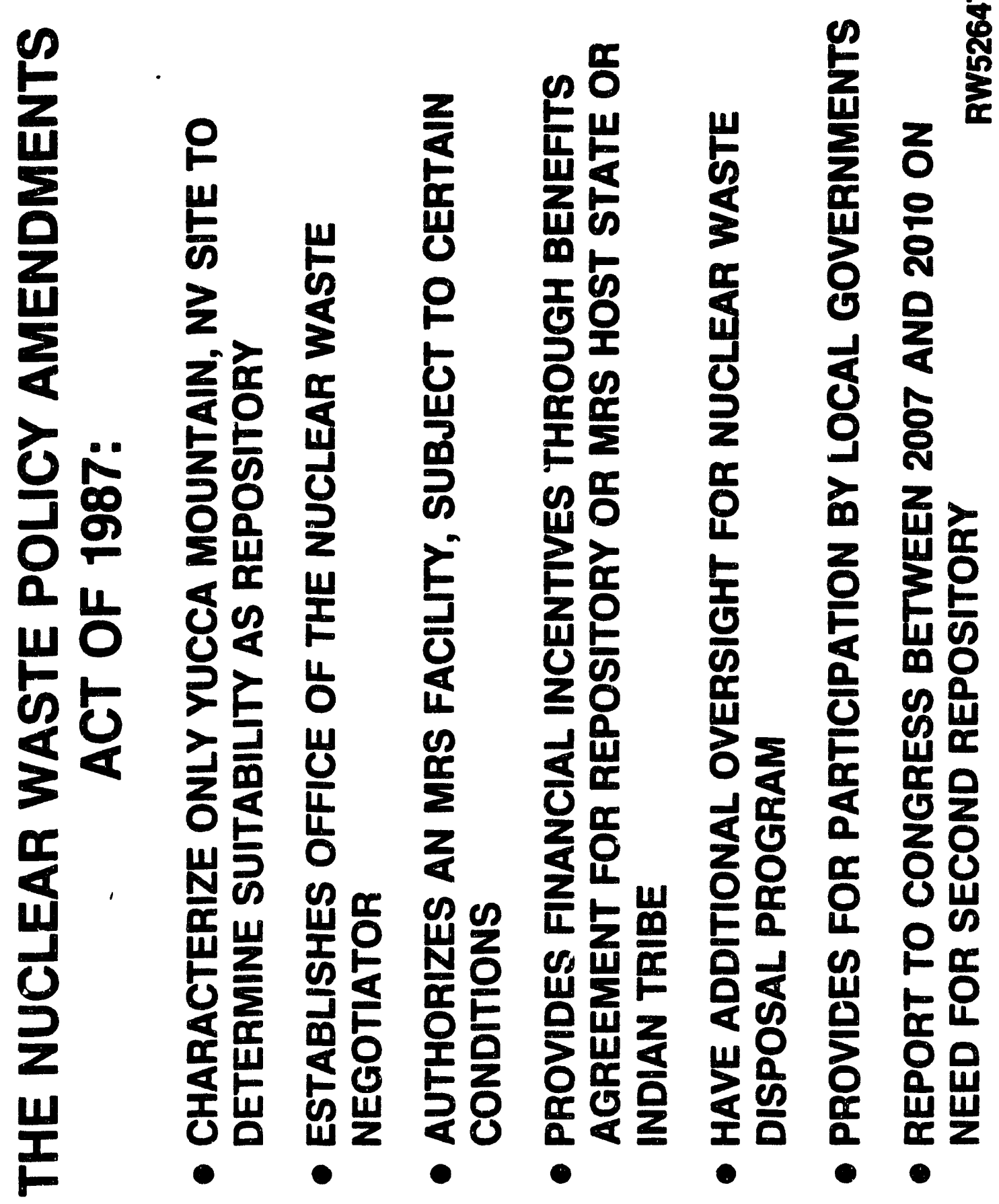




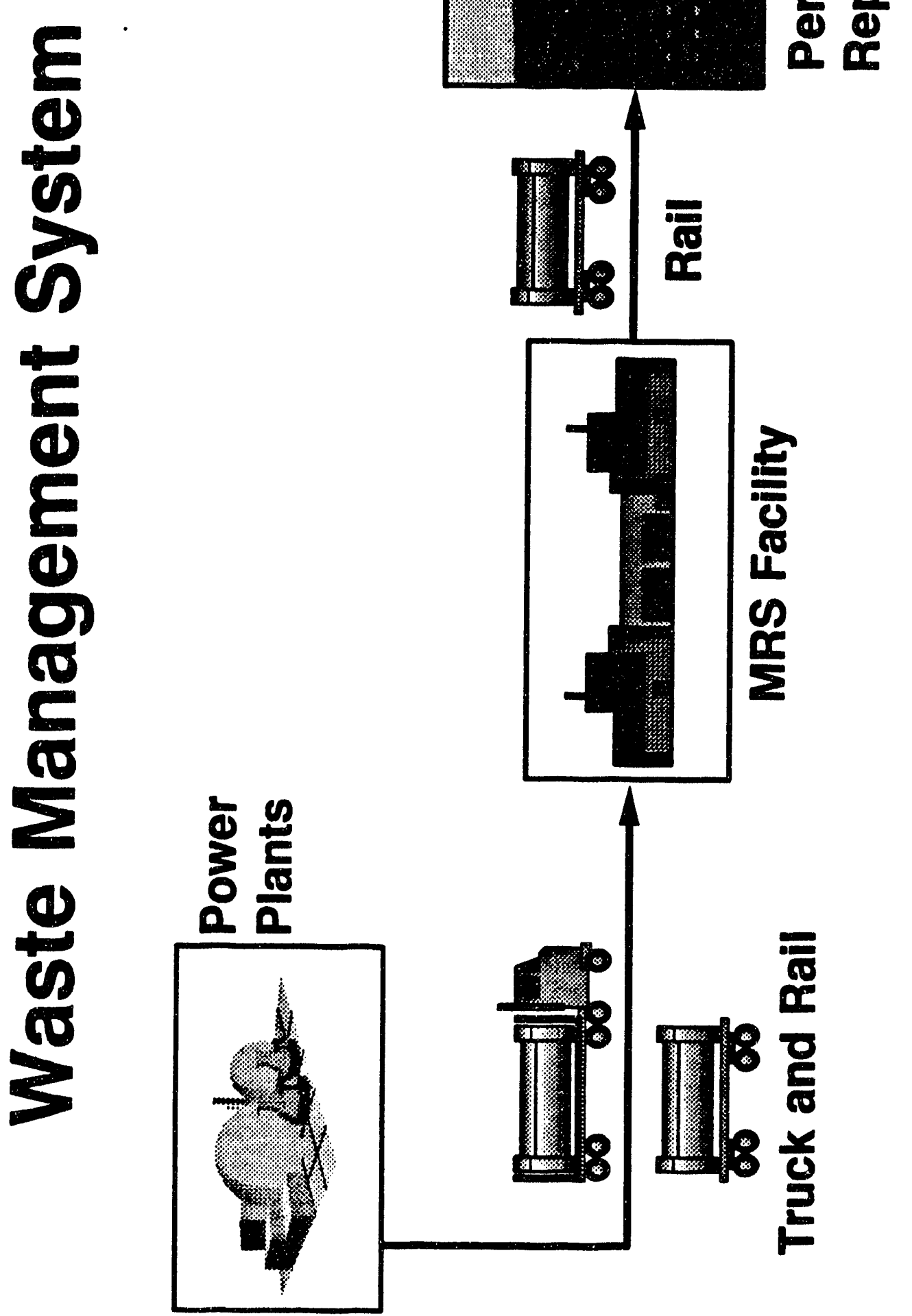




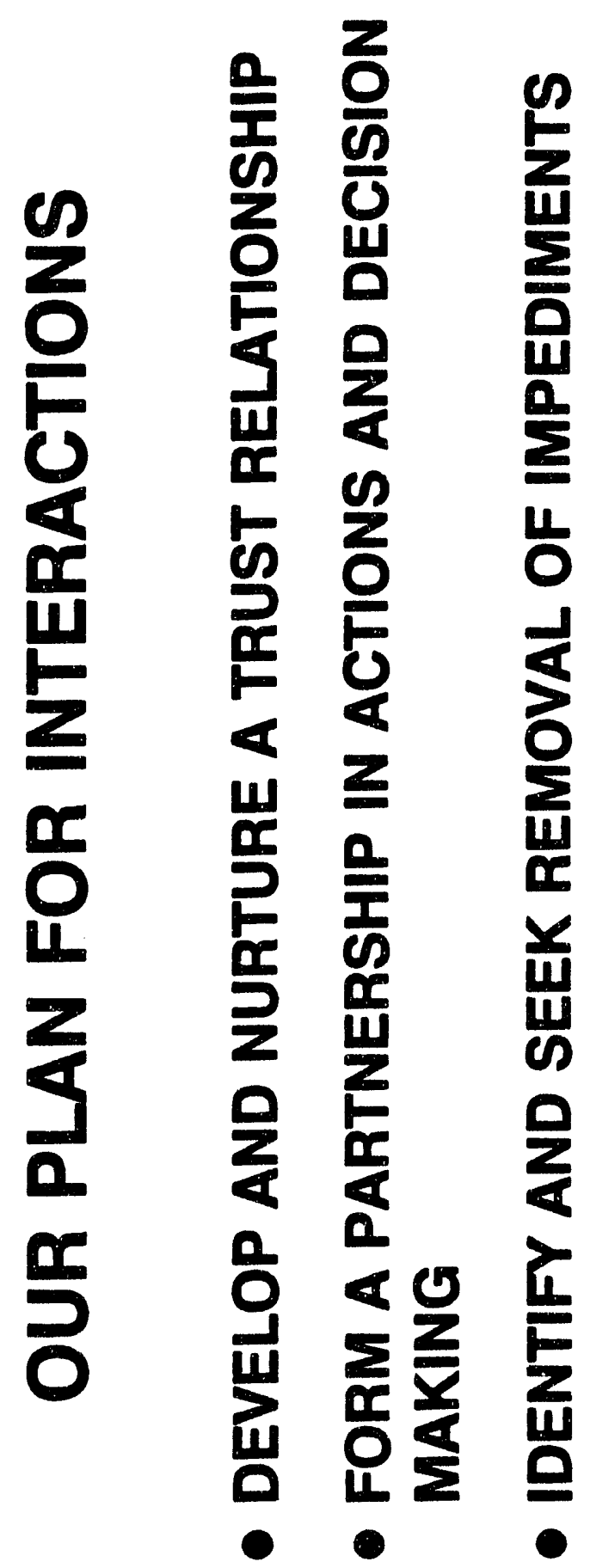




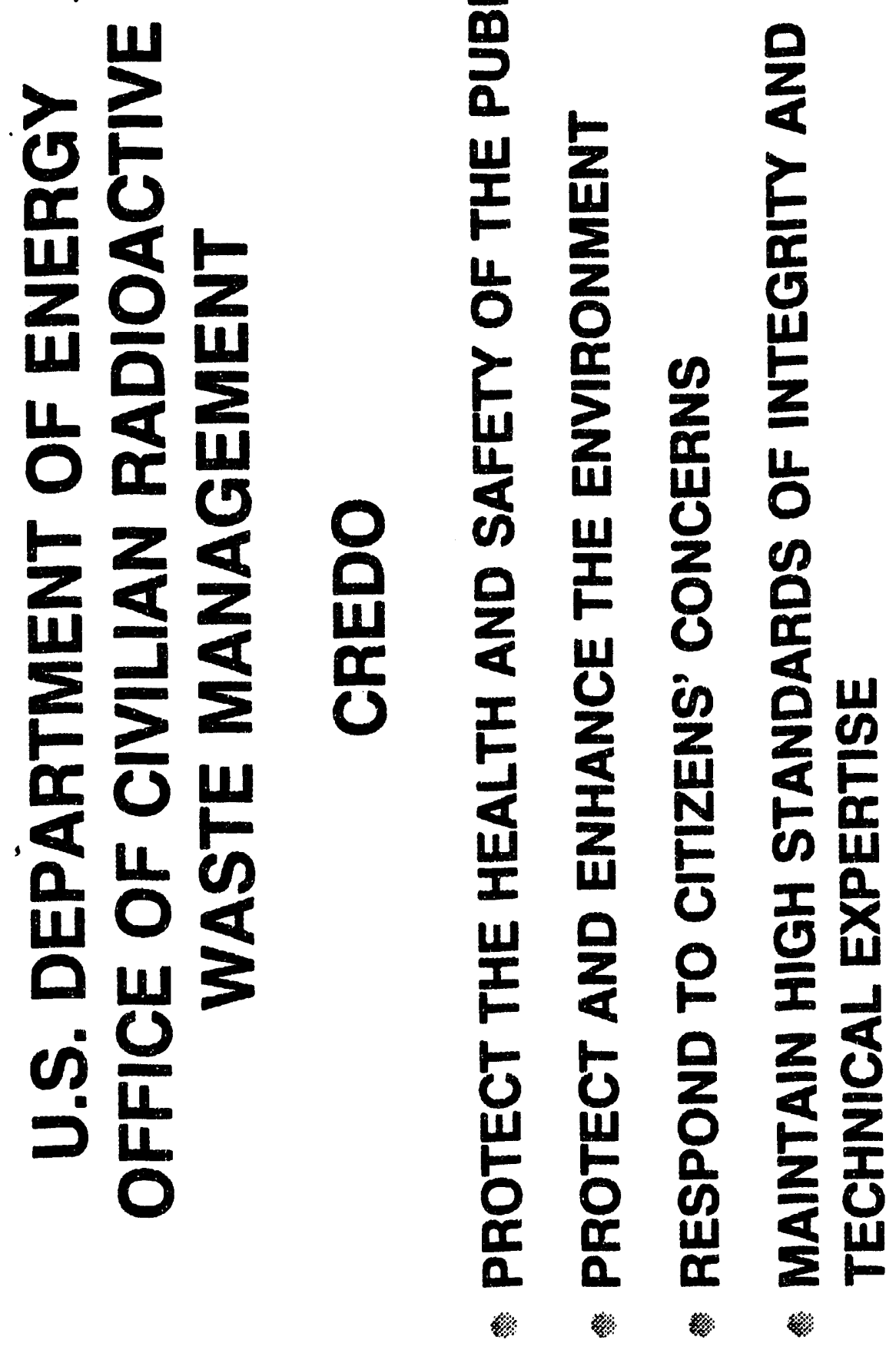


$\frac{8}{2}$

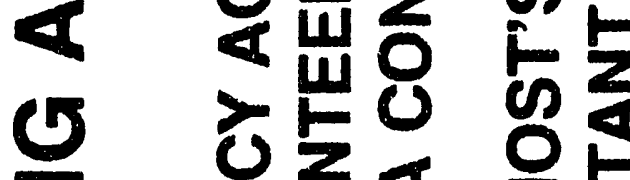

$11-2$

2 of $\frac{2}{1}$

- U.

- $9 \mathrm{n}$

4 II

of $4=$

3 u

$+2$

(2) $2 \leq 2$

$8 m$

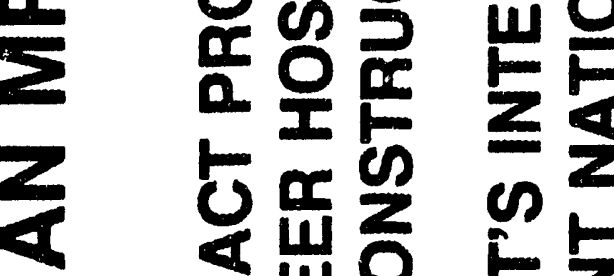

2

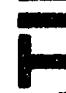

28

0

12

$0=2$

H -11

co $a$

$<\frac{0}{0}$

$=00$

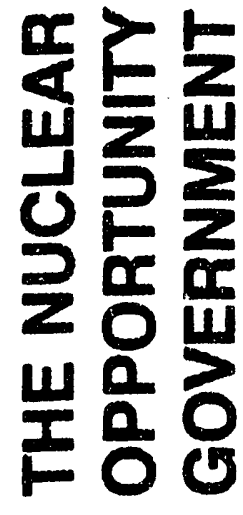

結

c) II

1

iil

iv 2

$\sum=$

III

3
110
02
02

$\sum_{-1}^{\infty}$

$\frac{111}{4} \frac{\pi}{4}$

20

$\sum_{-1}^{14} \frac{1}{2}$

II) 0

5

$1 \leq$

$11=$

$n<$

II)

운

$\sum \mu$

25

10

is

다 $=$

- 00

:

络

$8 \%$

i1) 0

$\geq 01$

$4 \infty 0$

( 0 il

c) 1

$\Rightarrow 0$

ก 4

iII $=0$

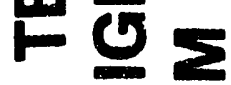

II) o $\mathrm{nc}$

대 $\mathrm{M}$

變 


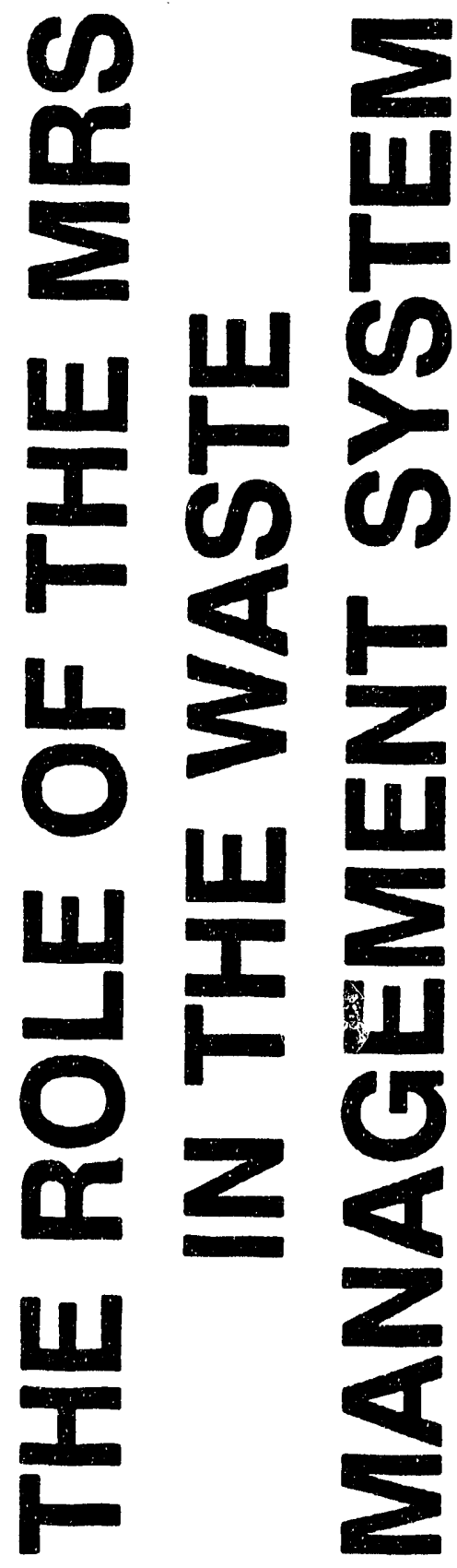




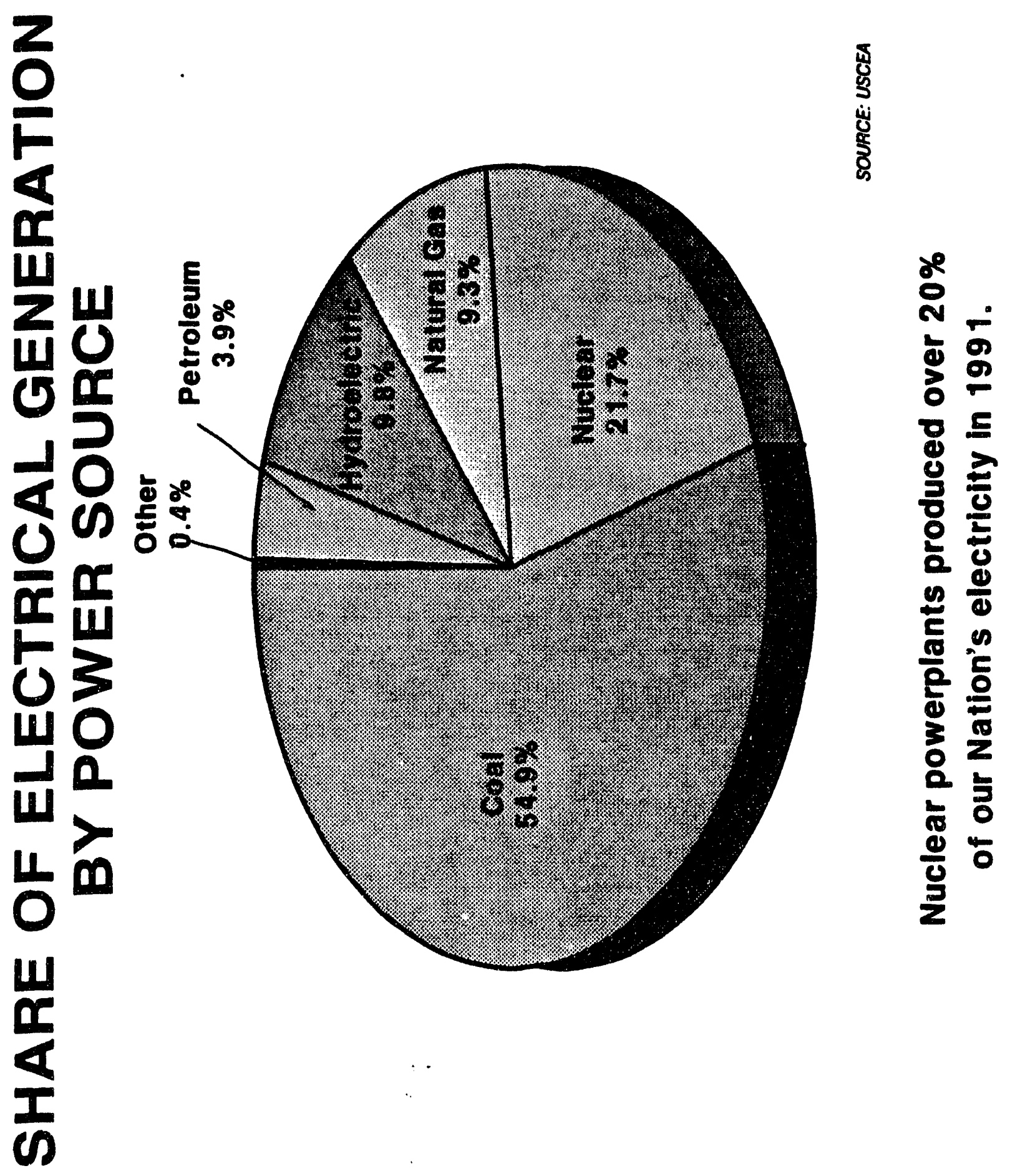




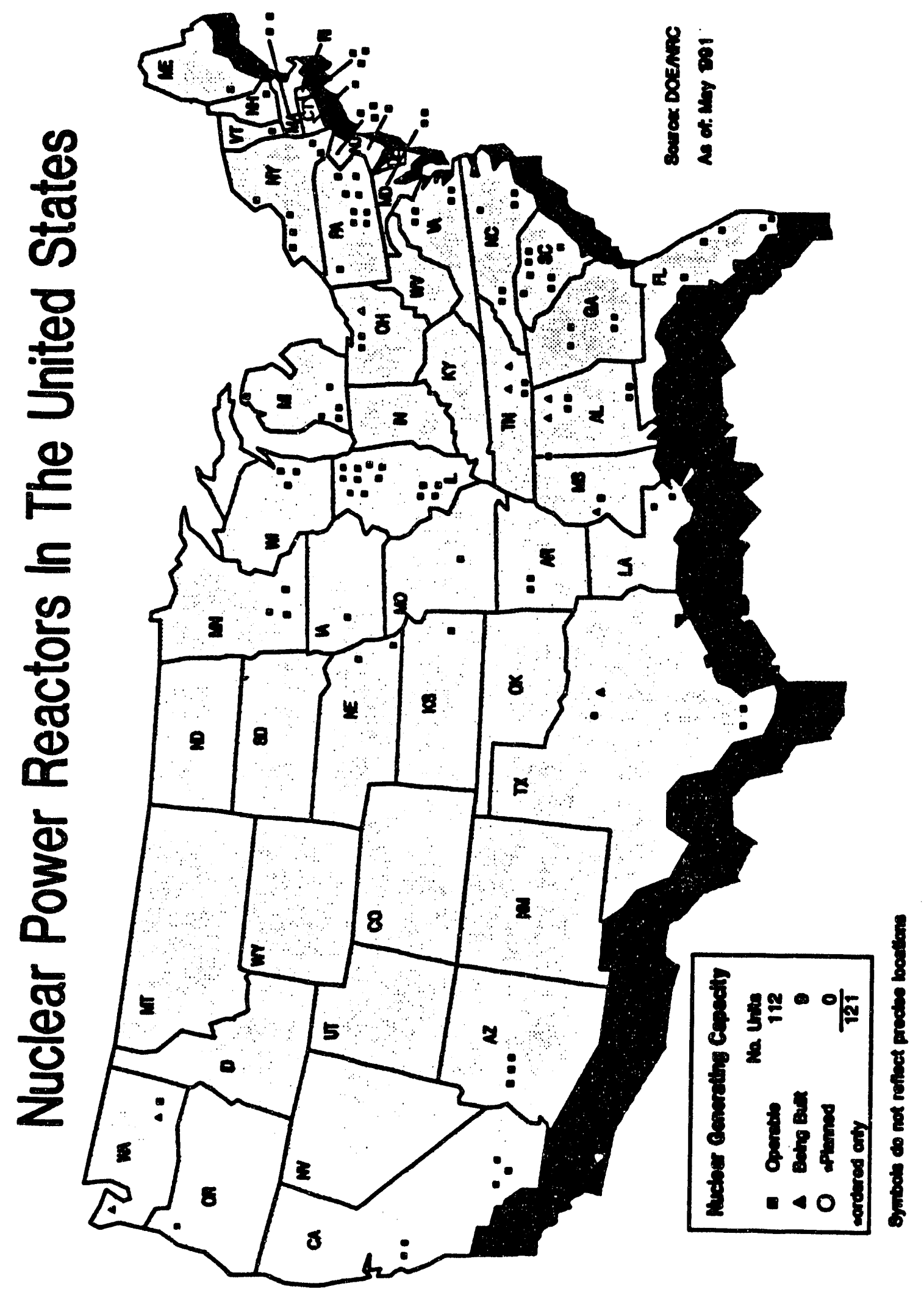




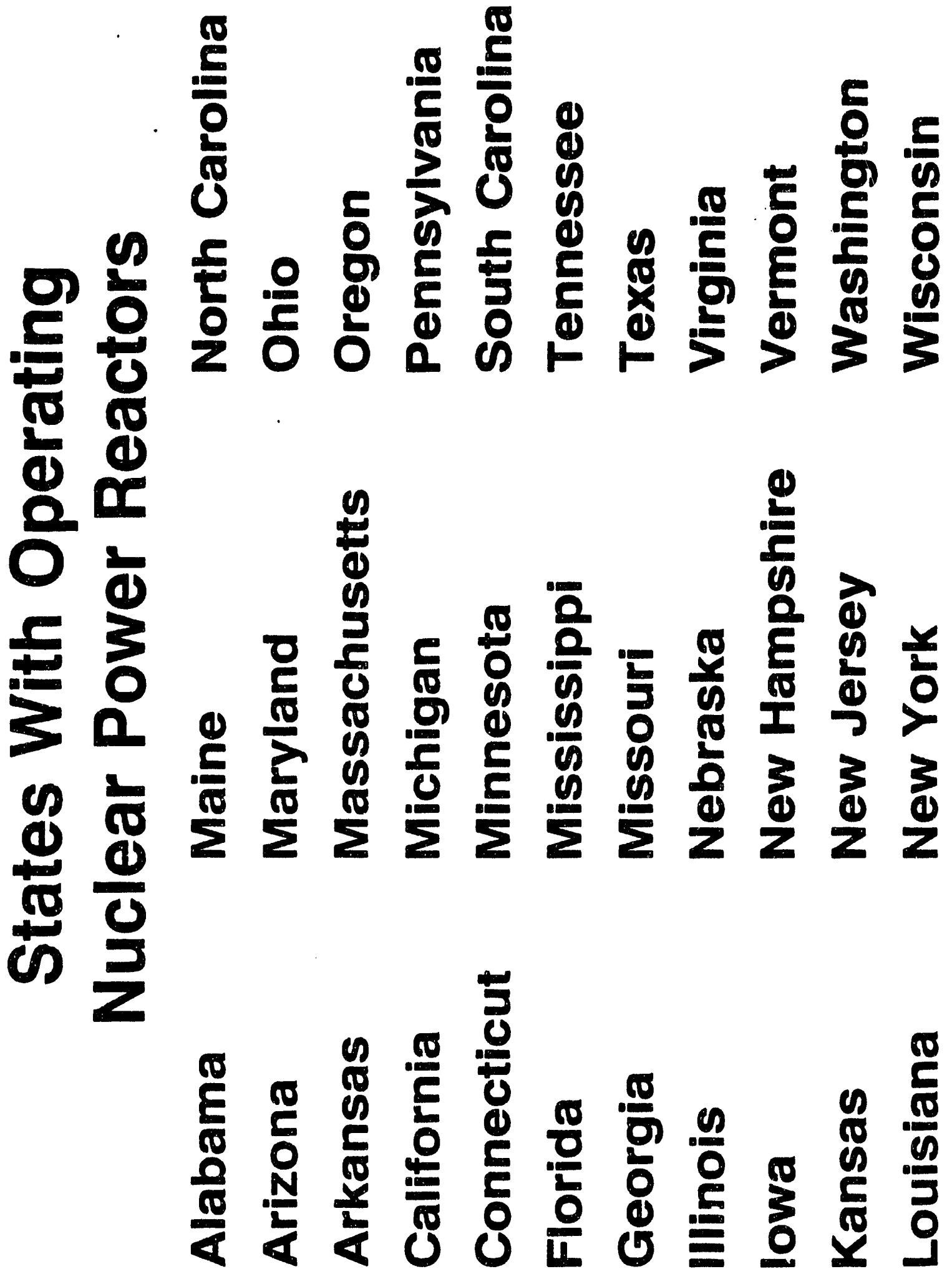




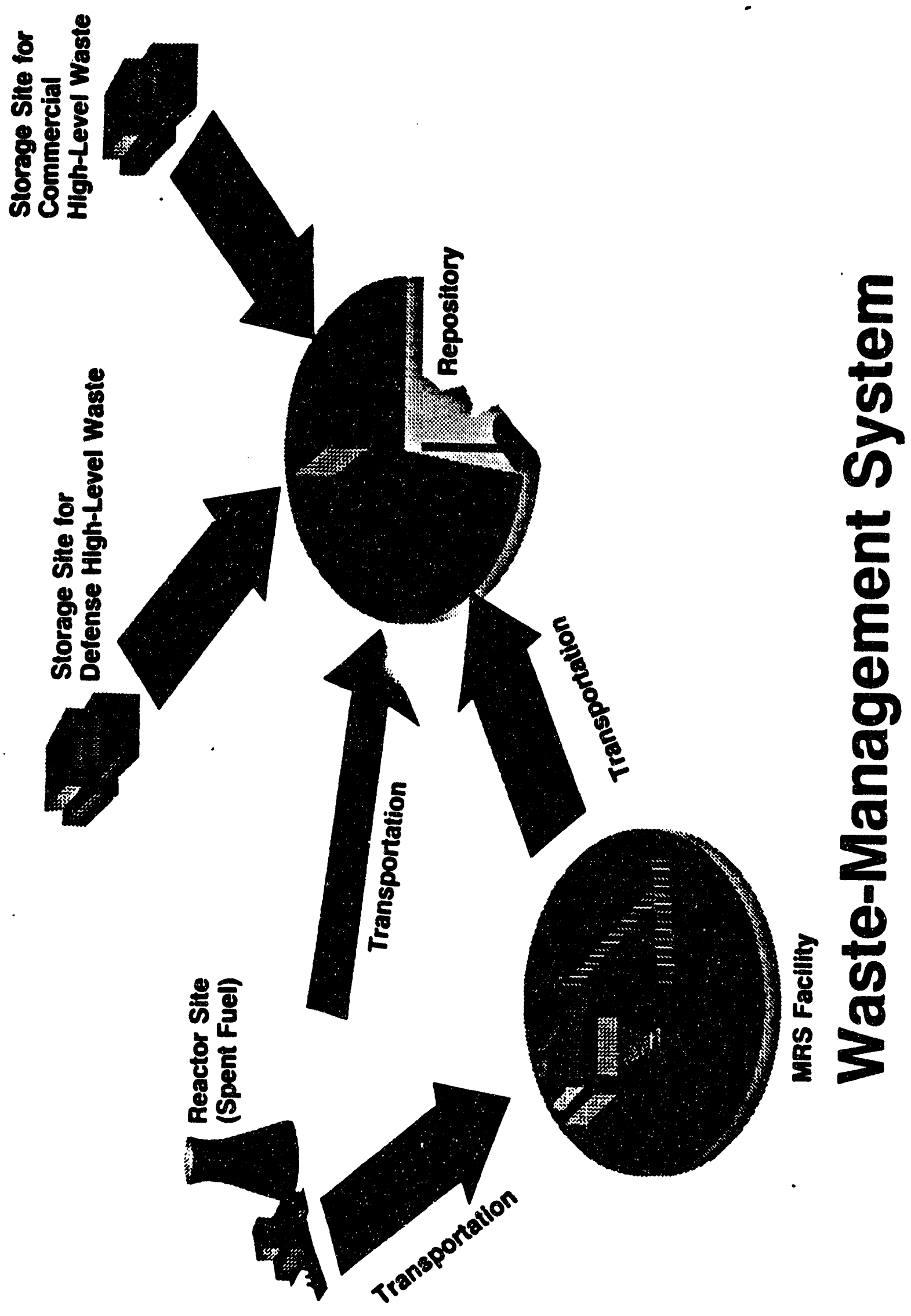




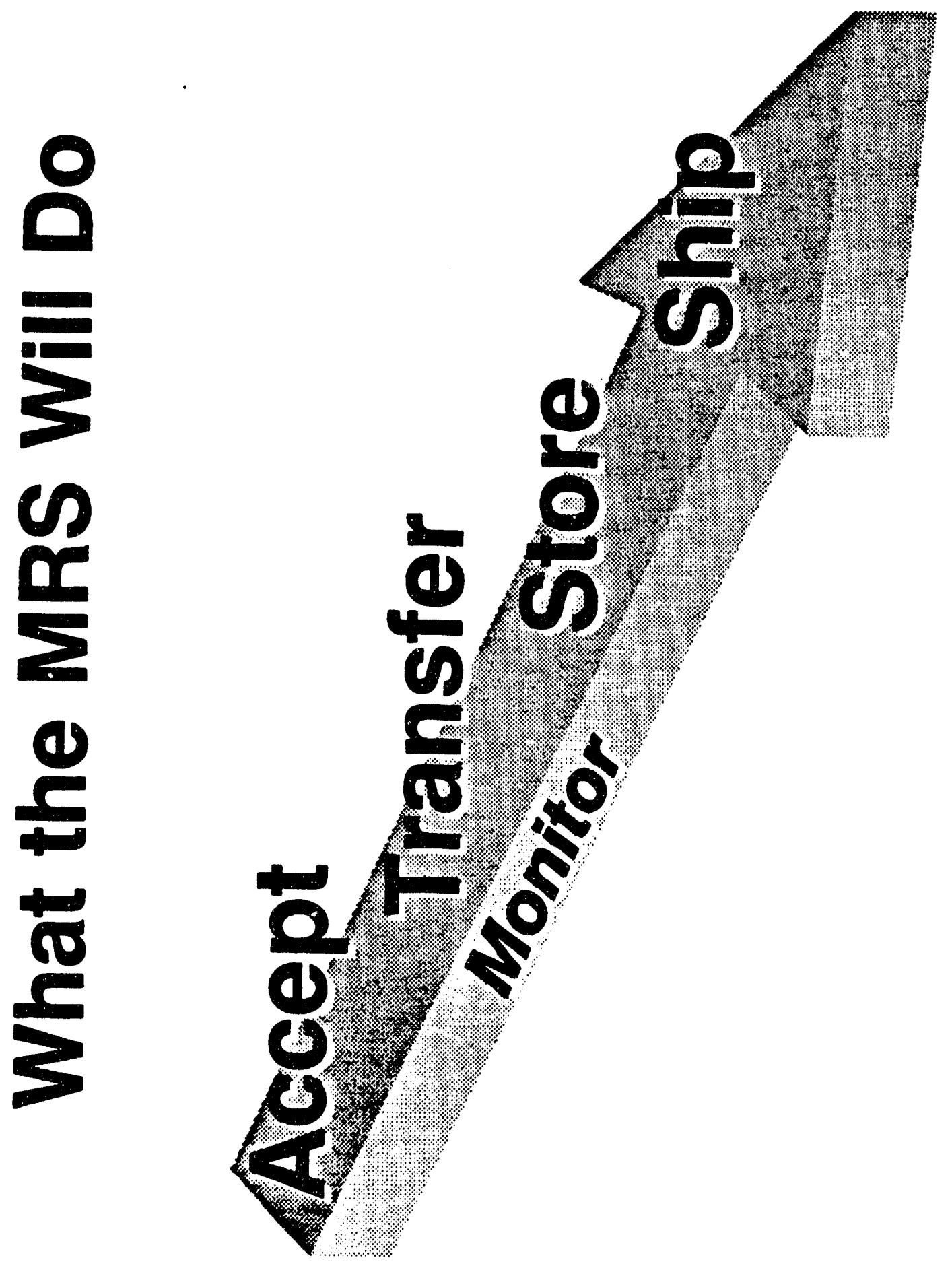




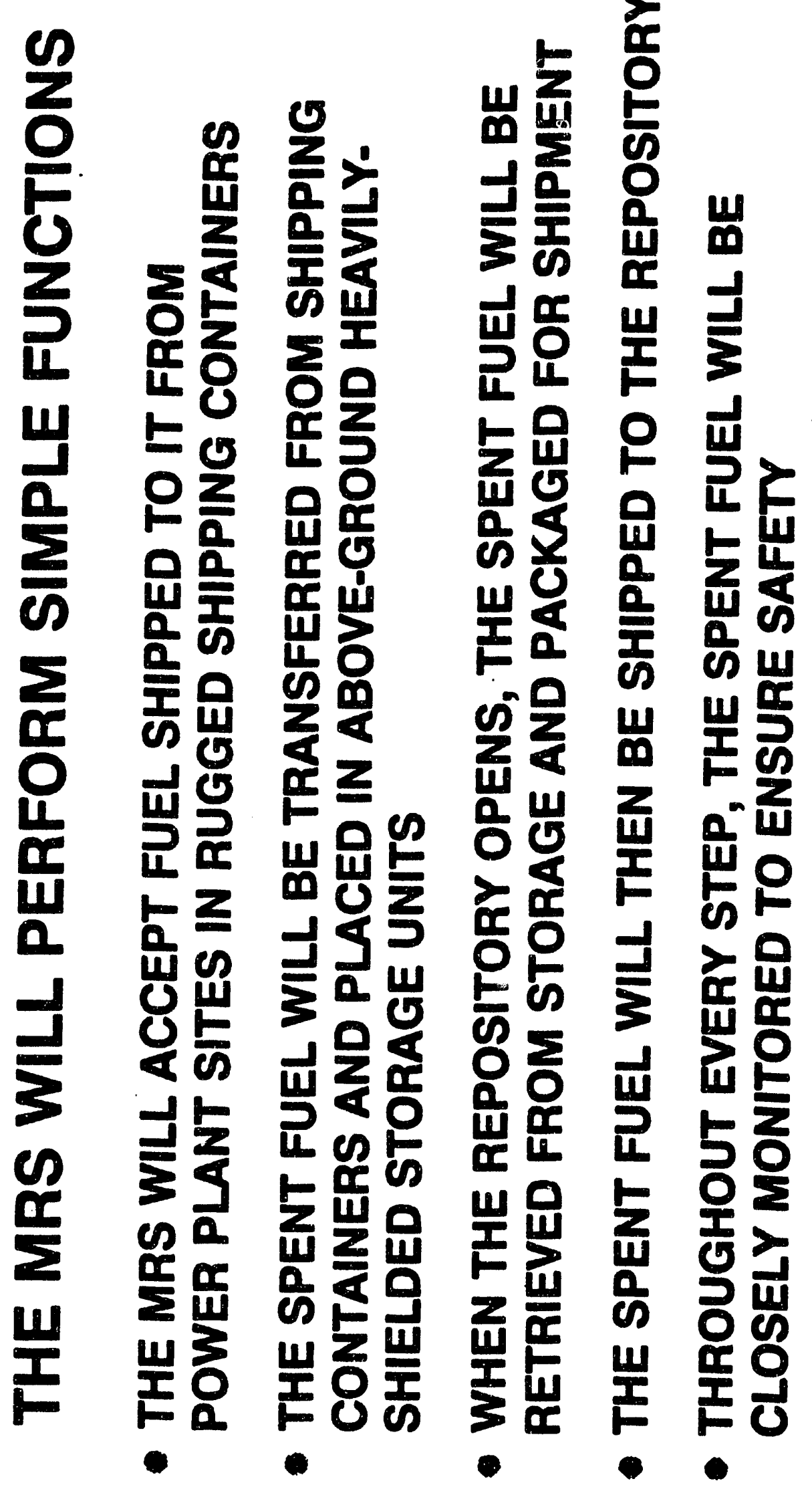




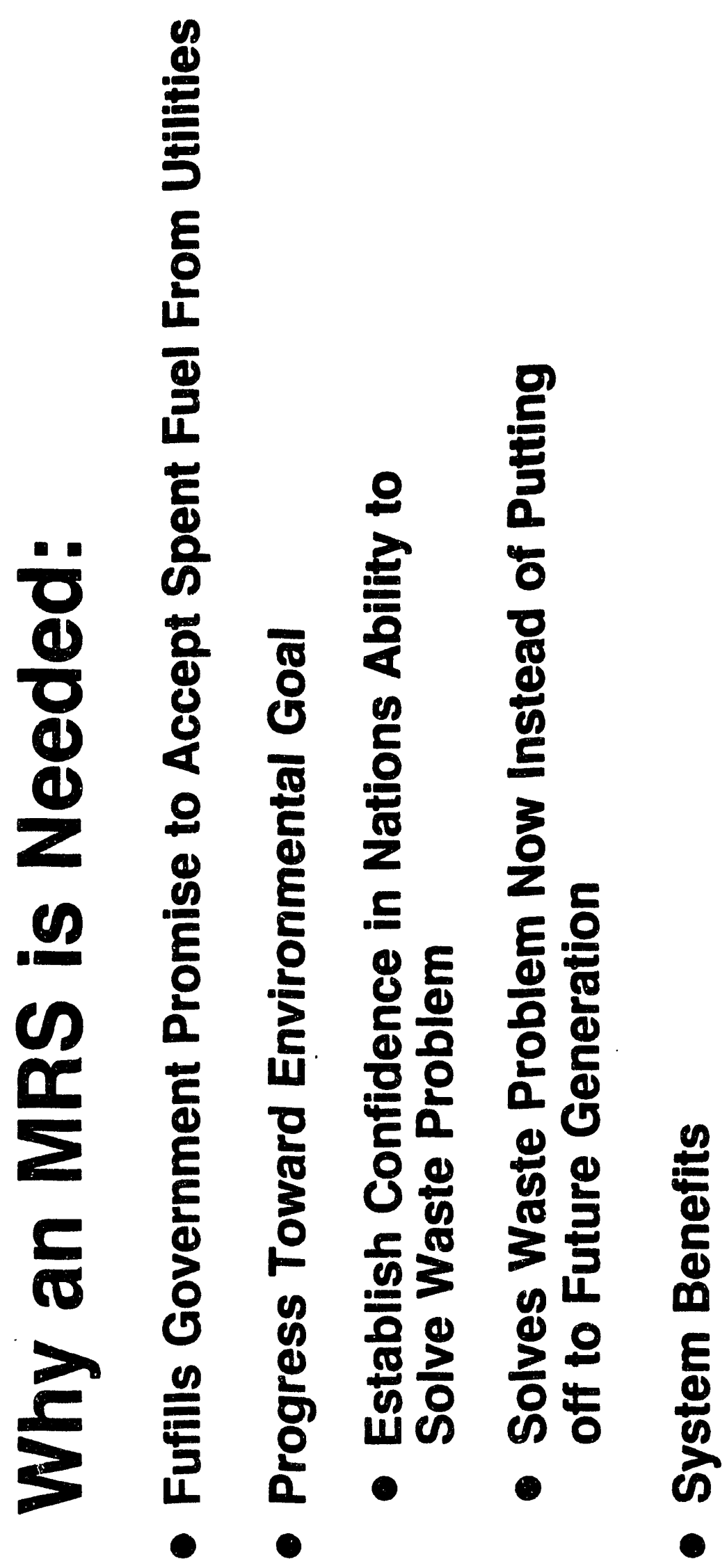




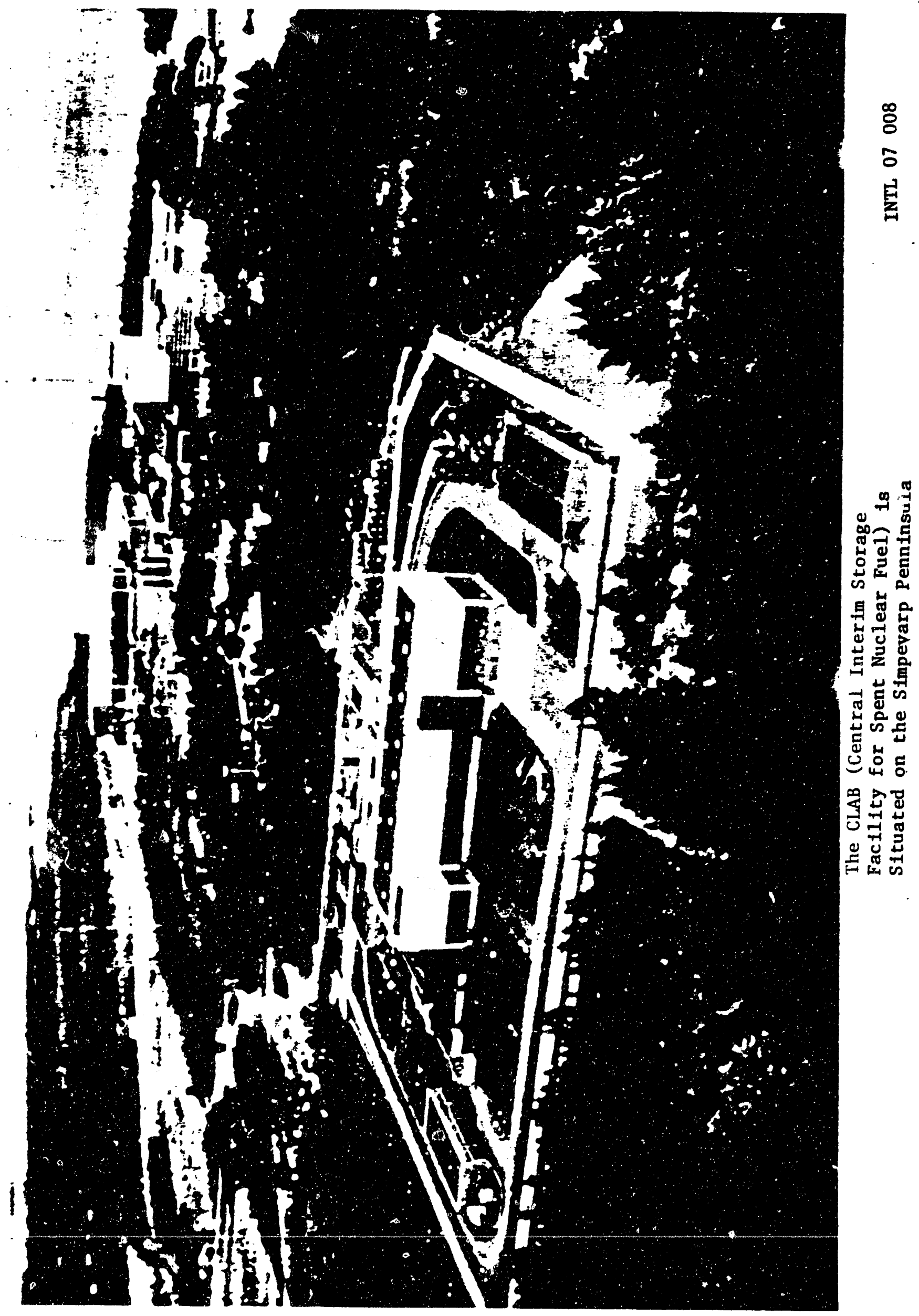




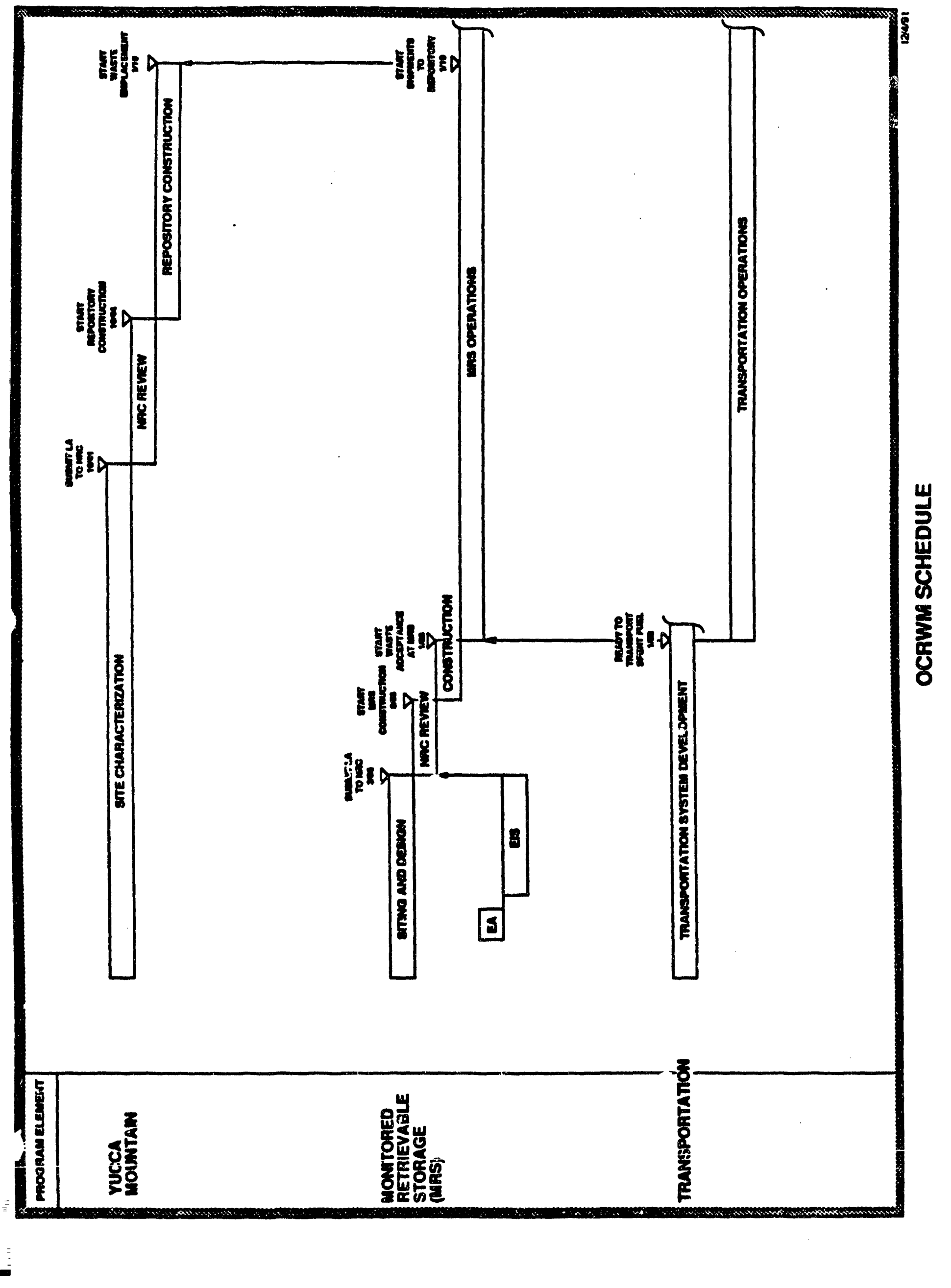




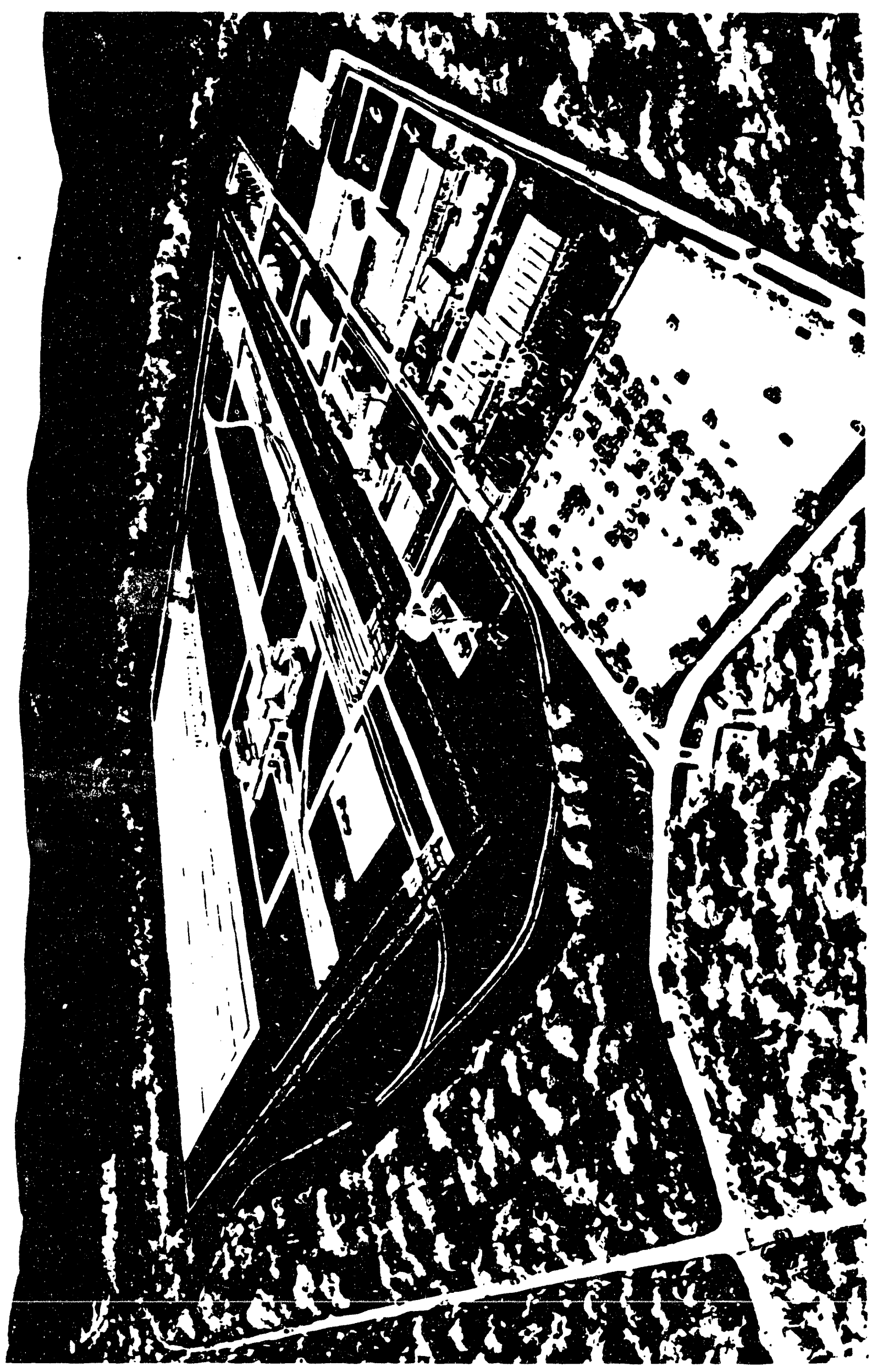




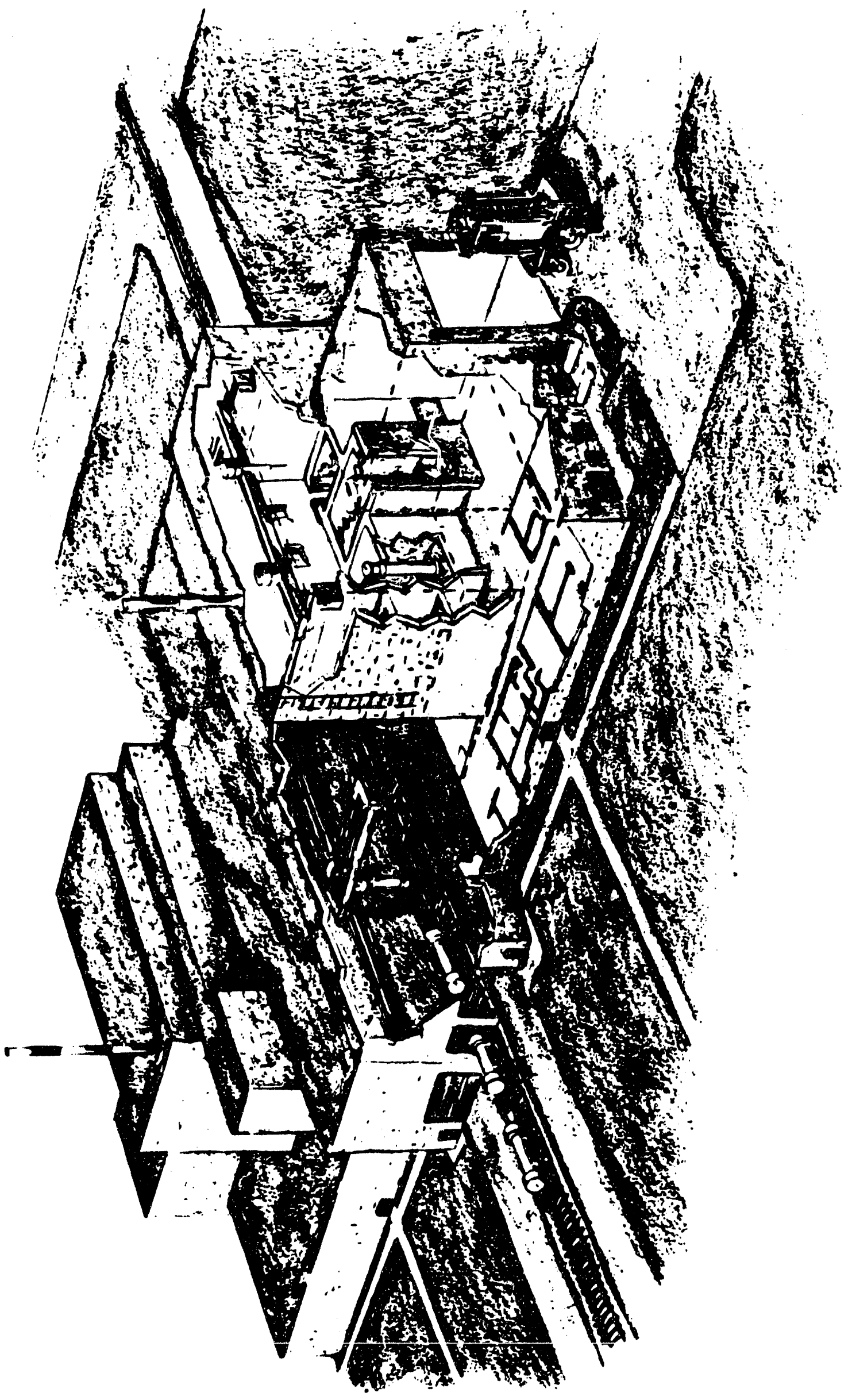




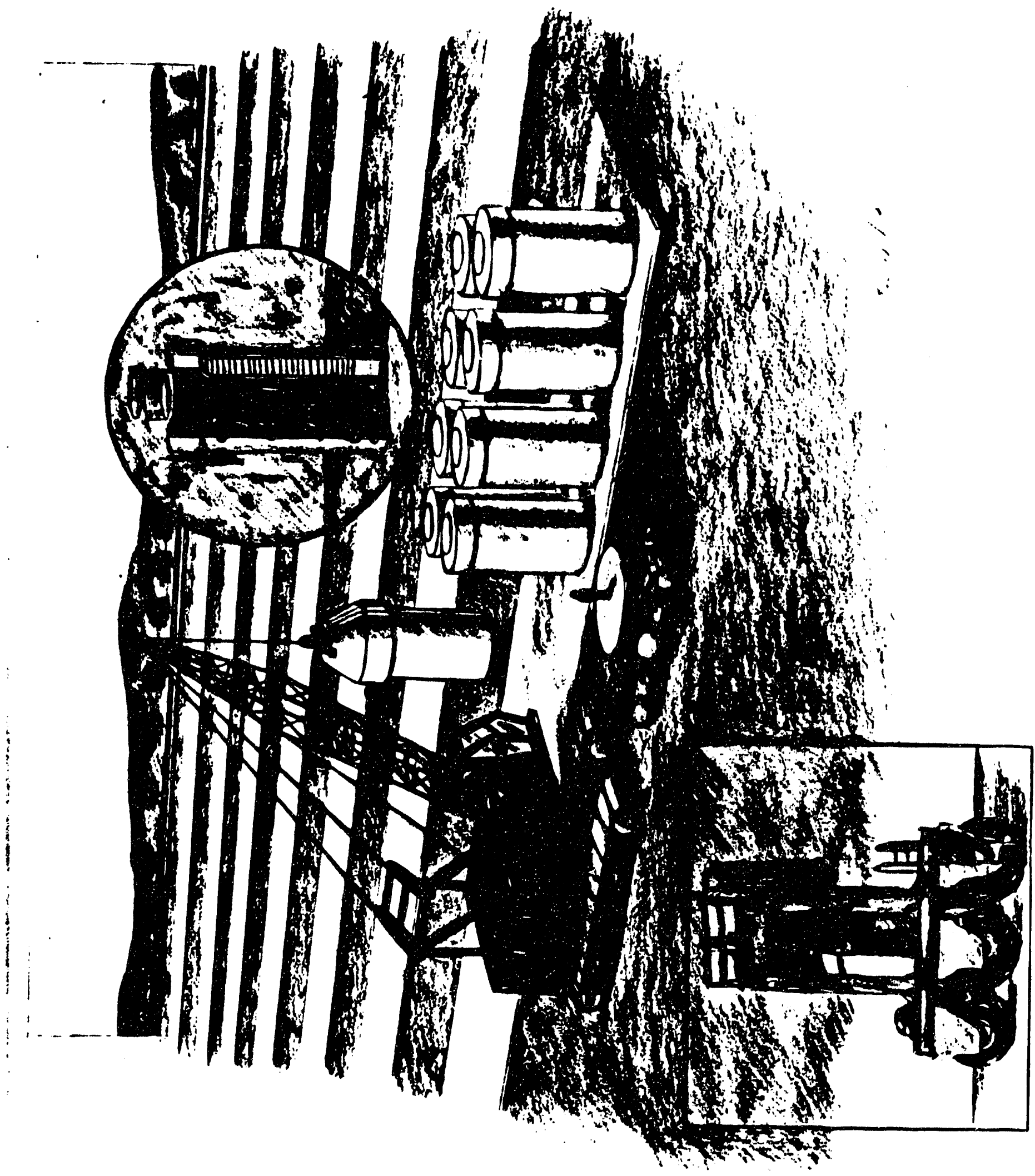




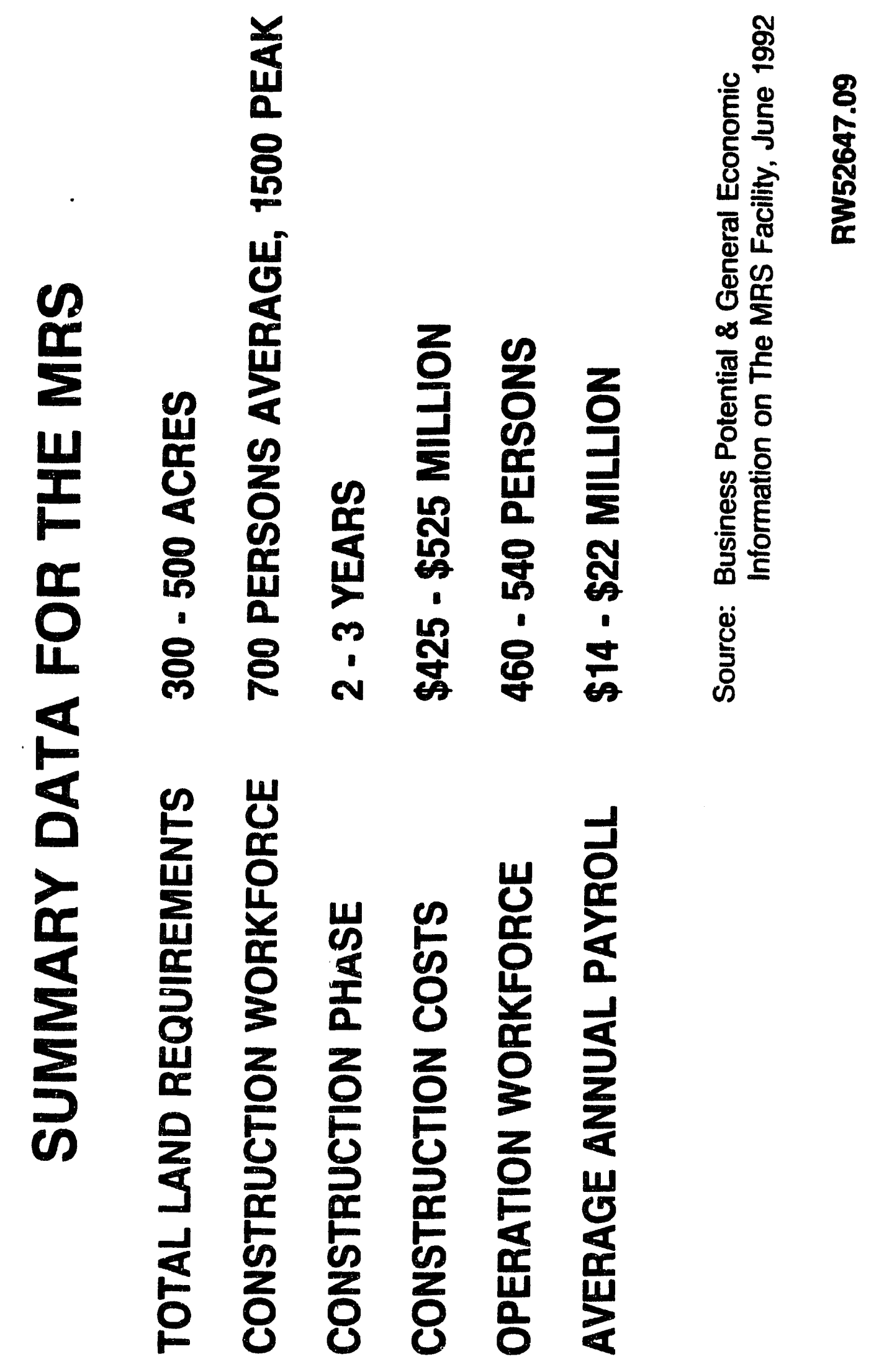




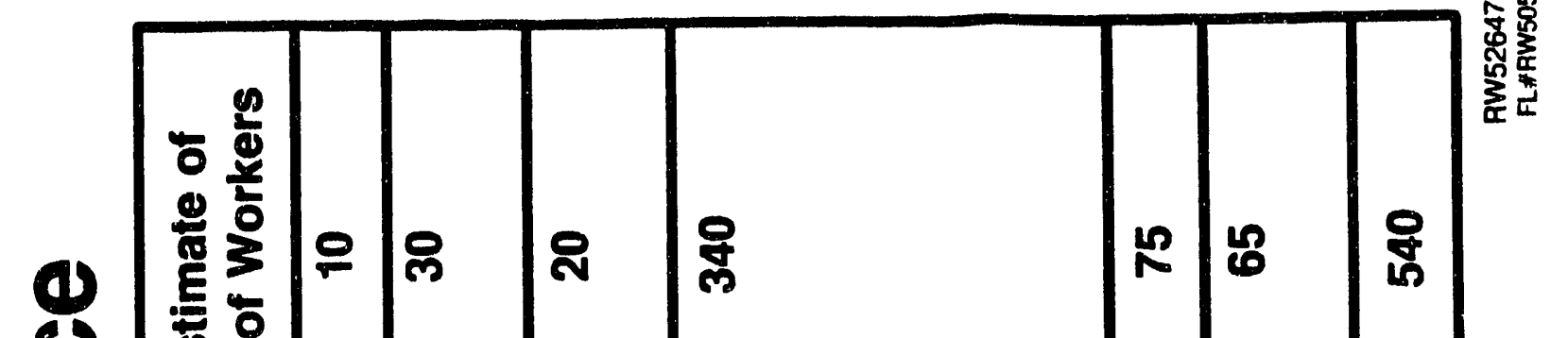




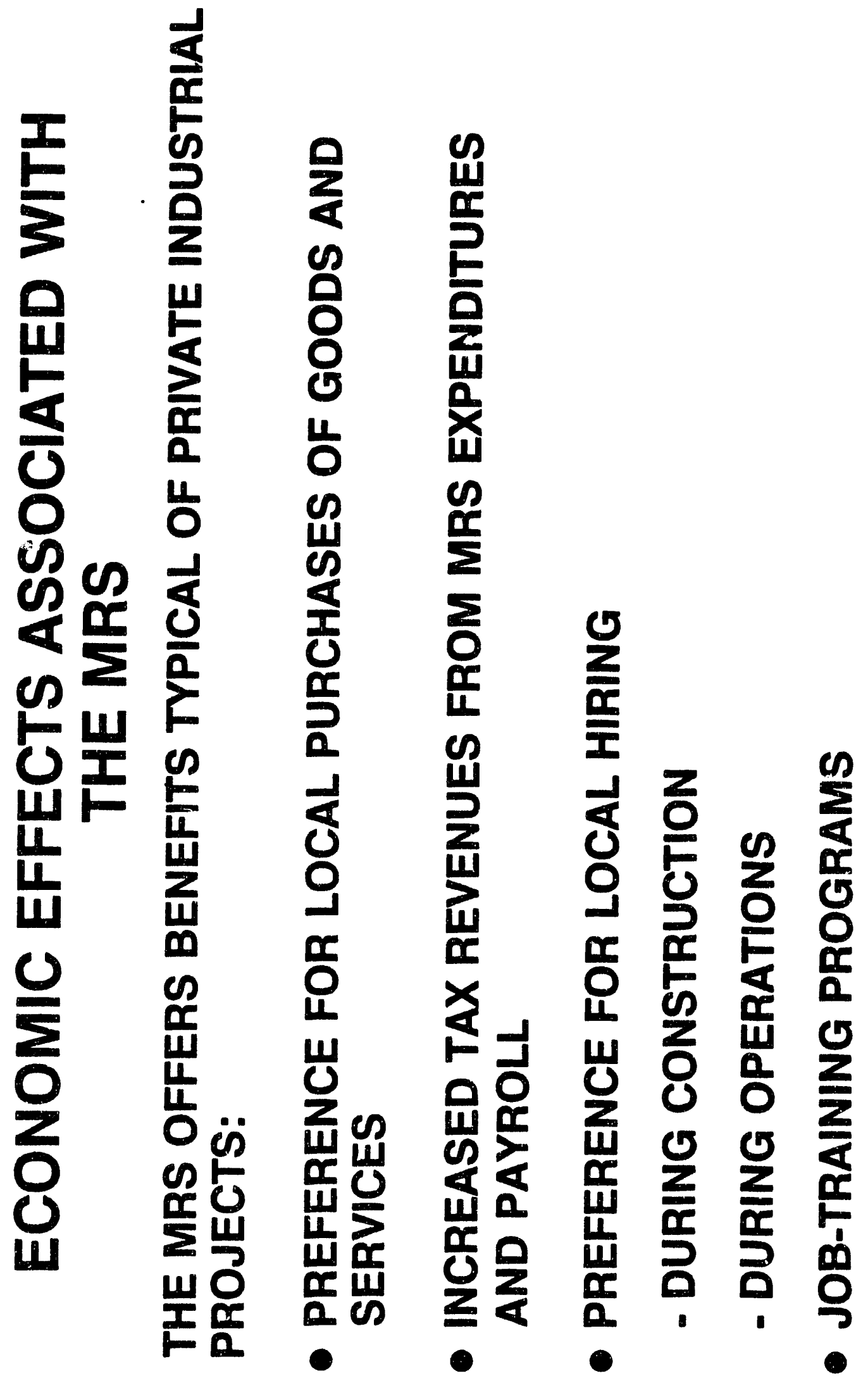




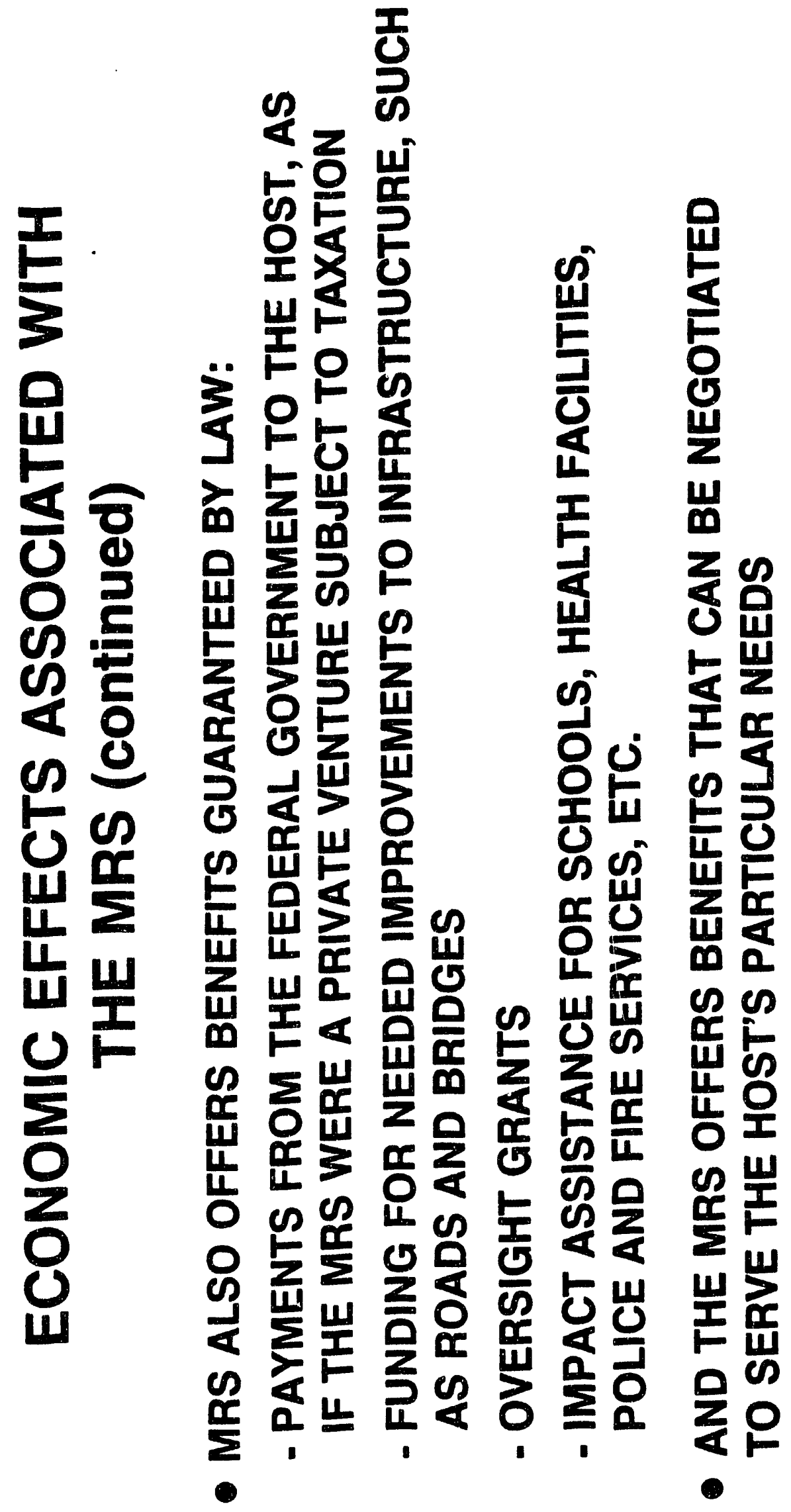




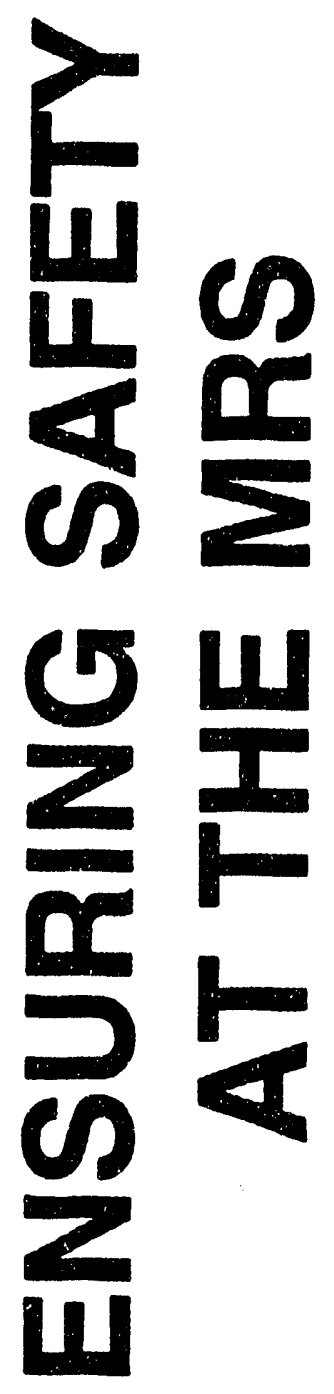




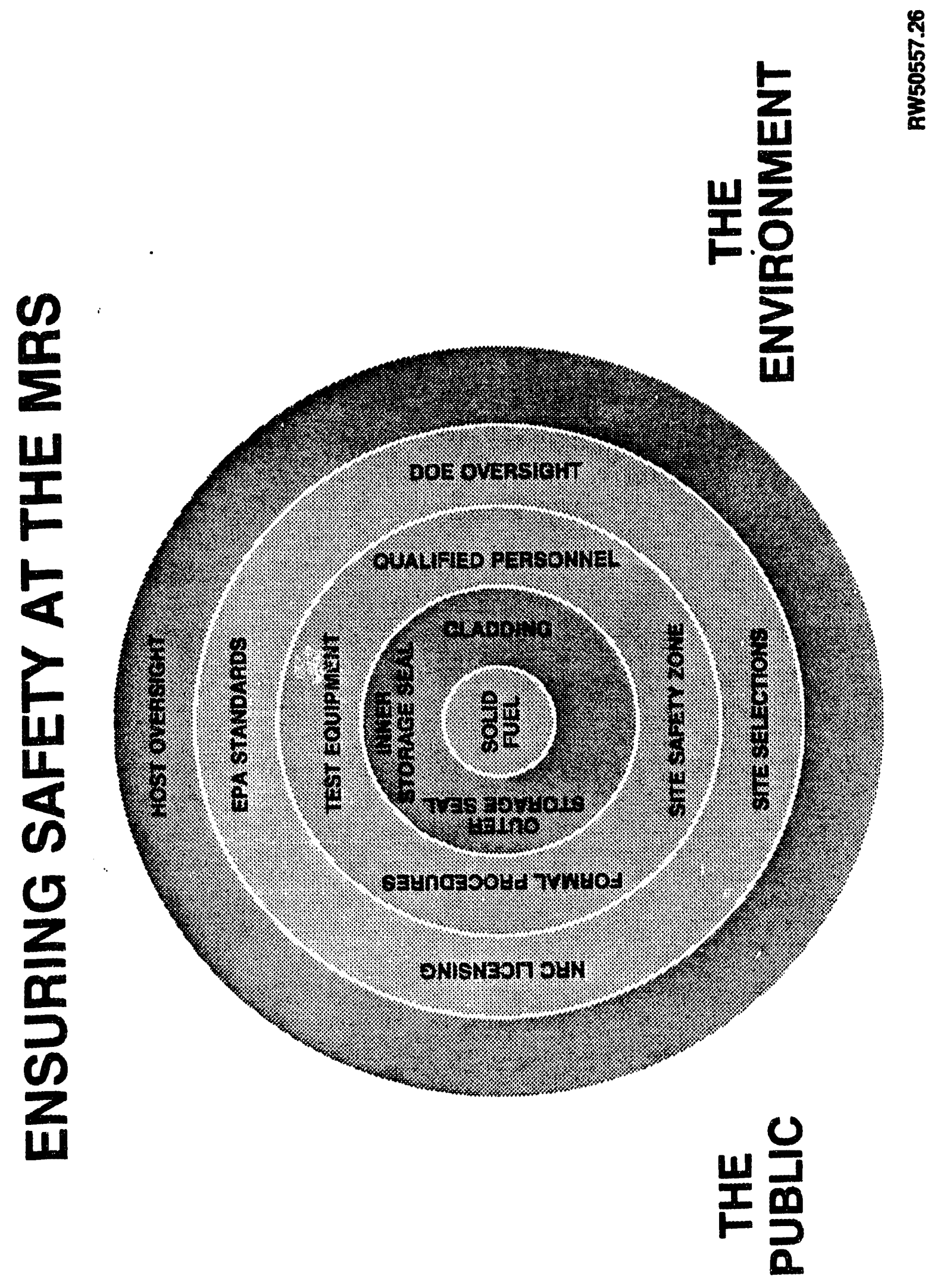




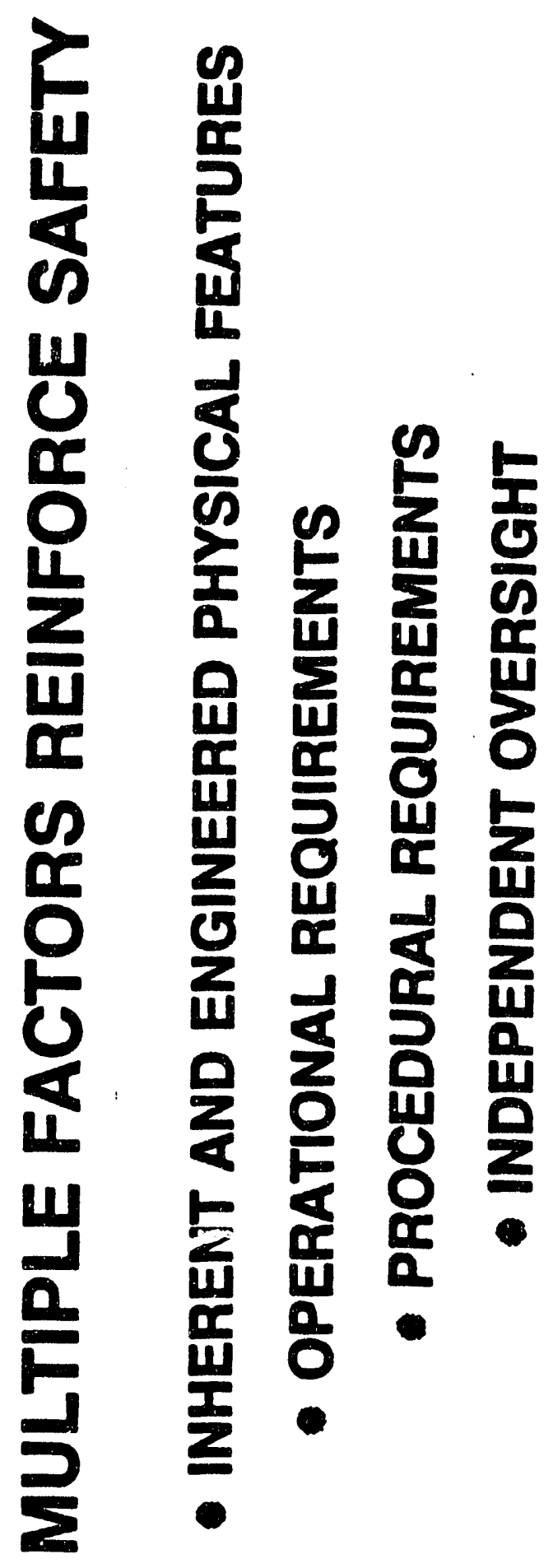




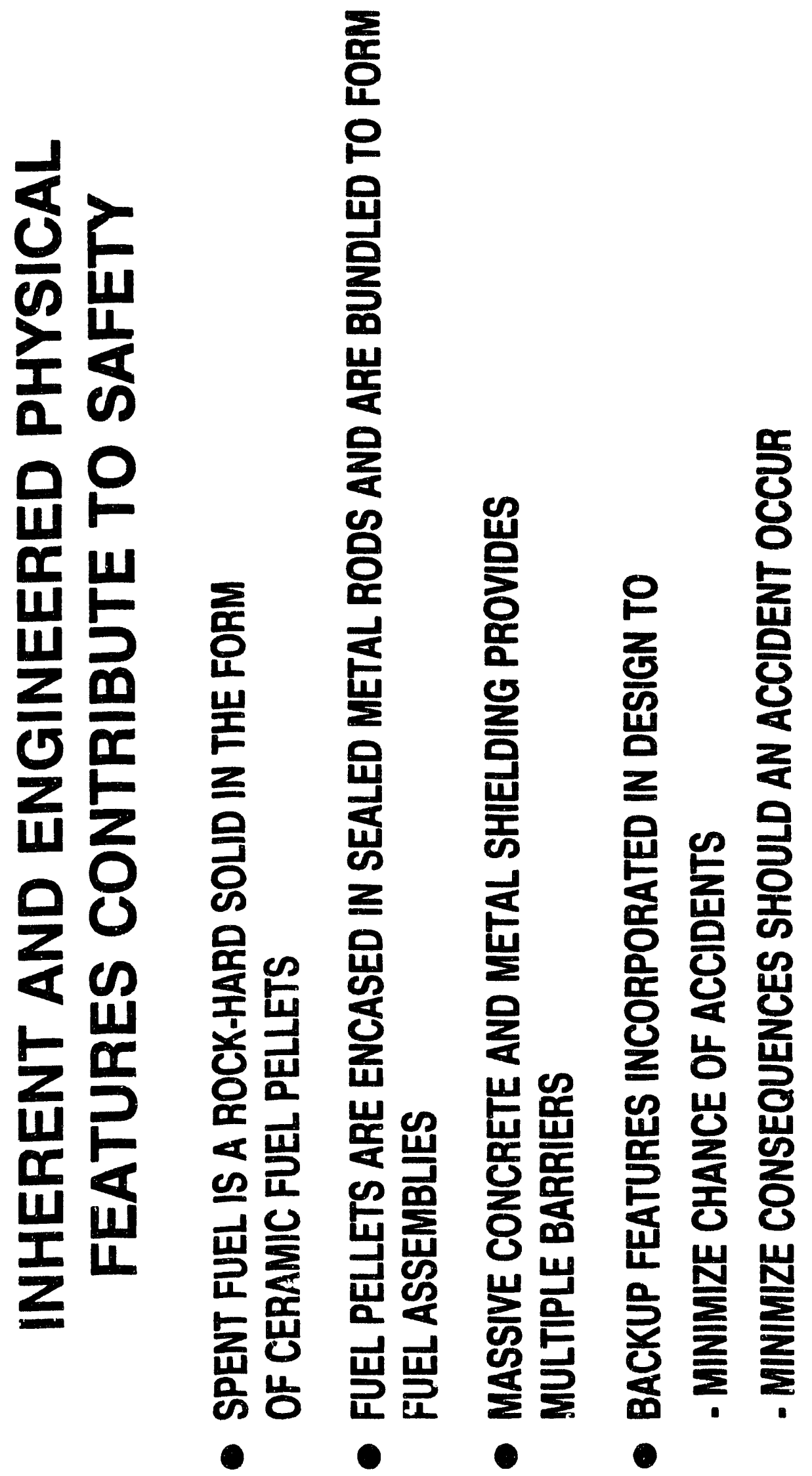




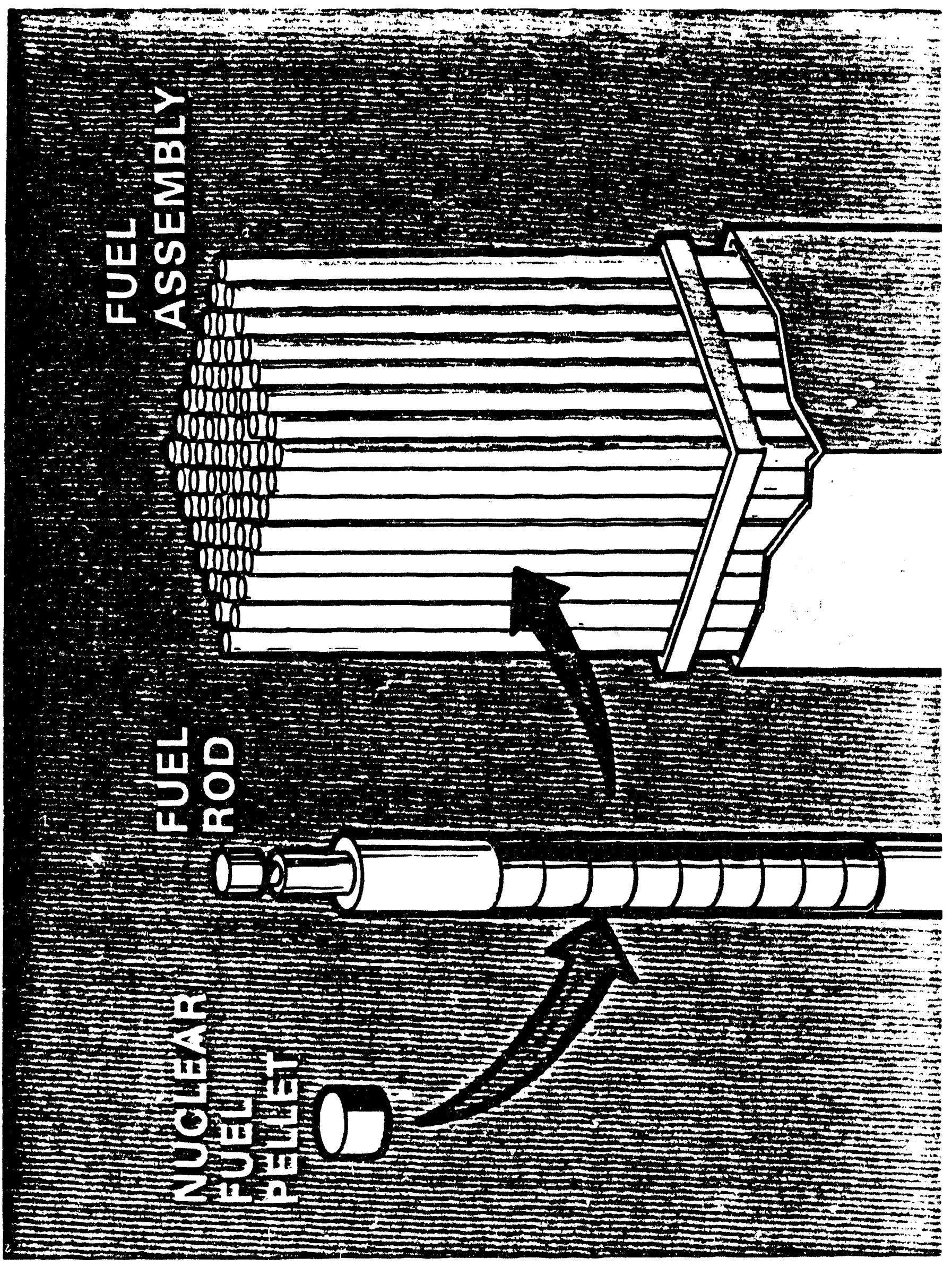




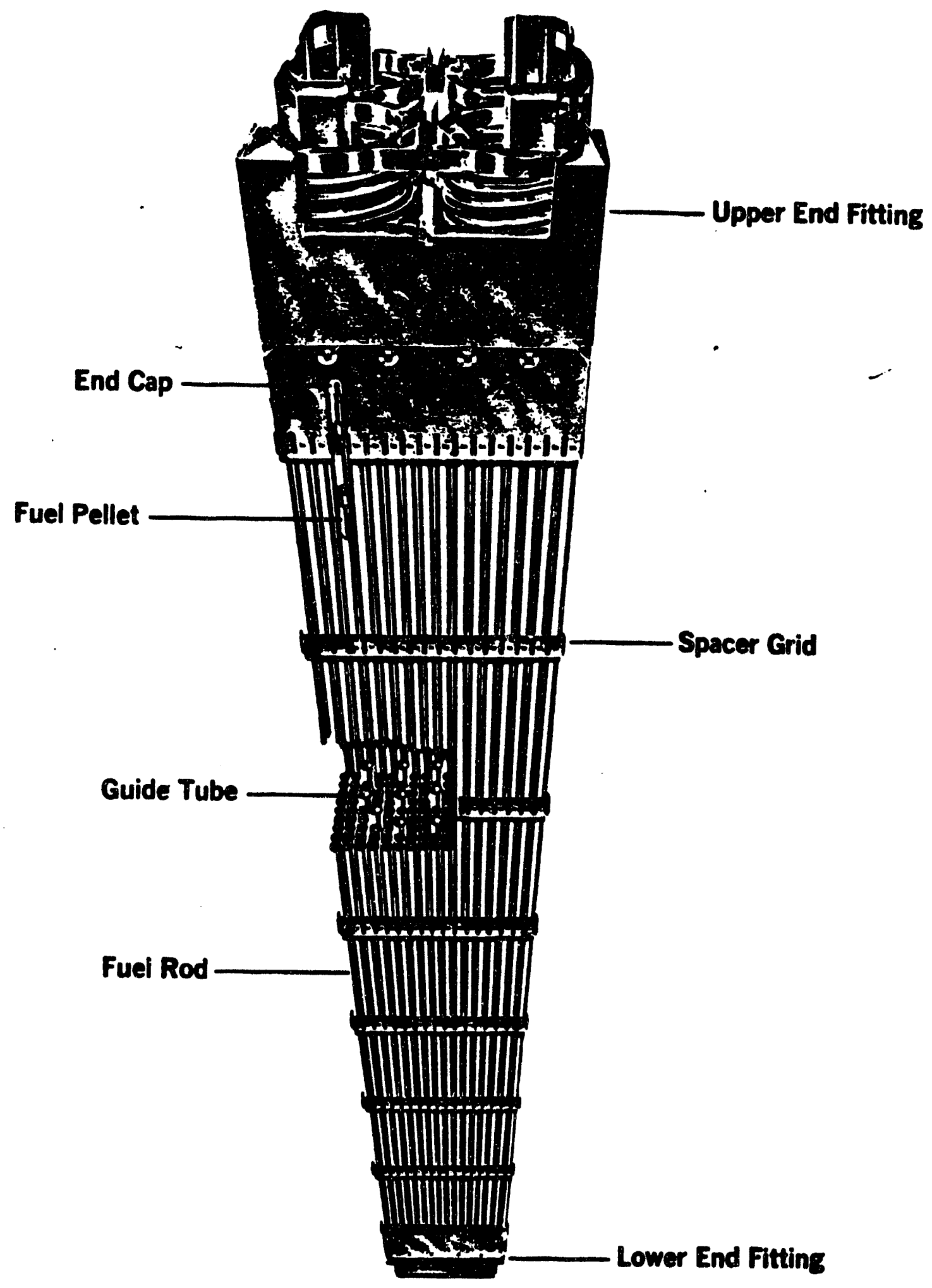

Babcock \& Wilcox 


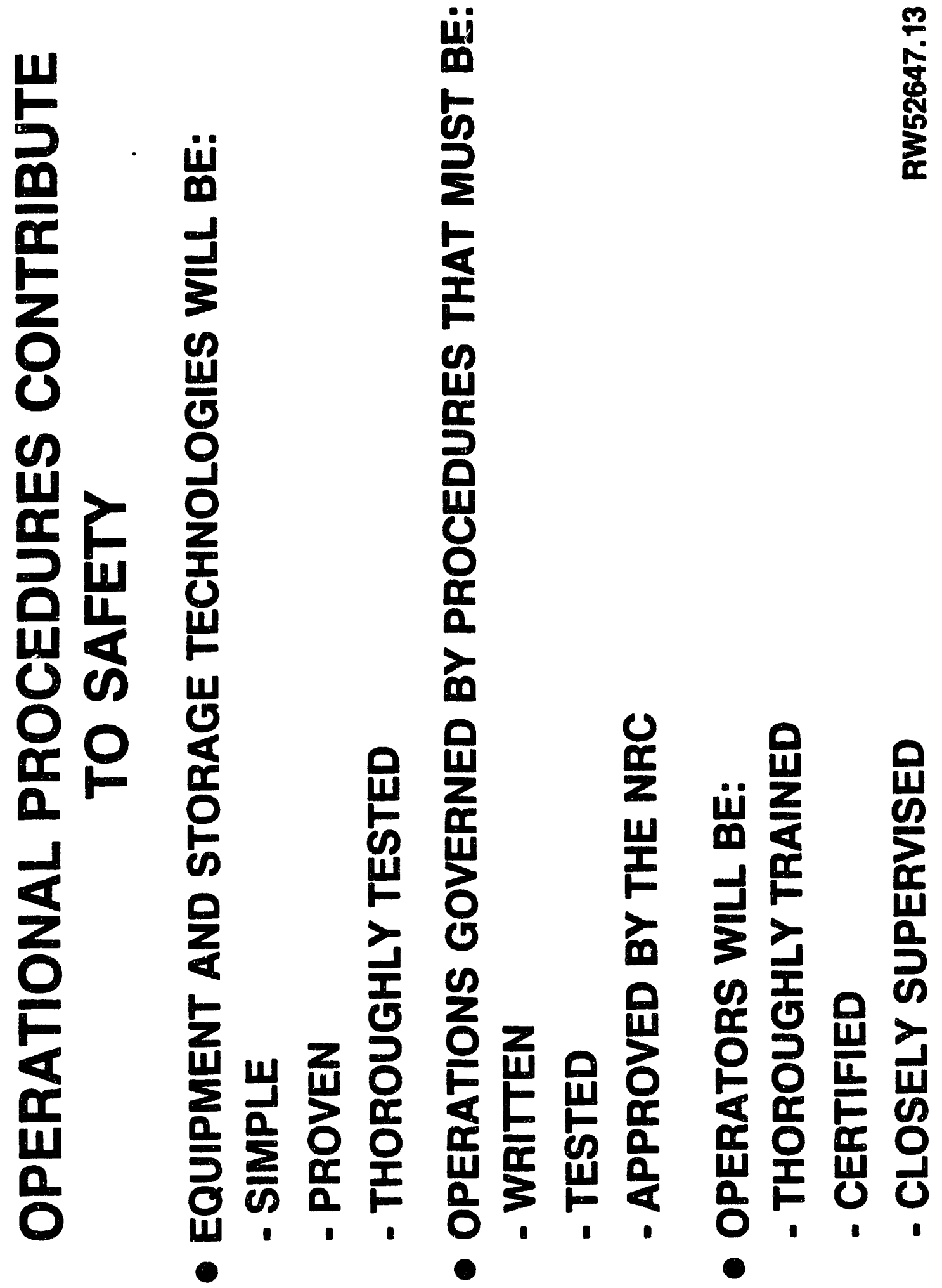




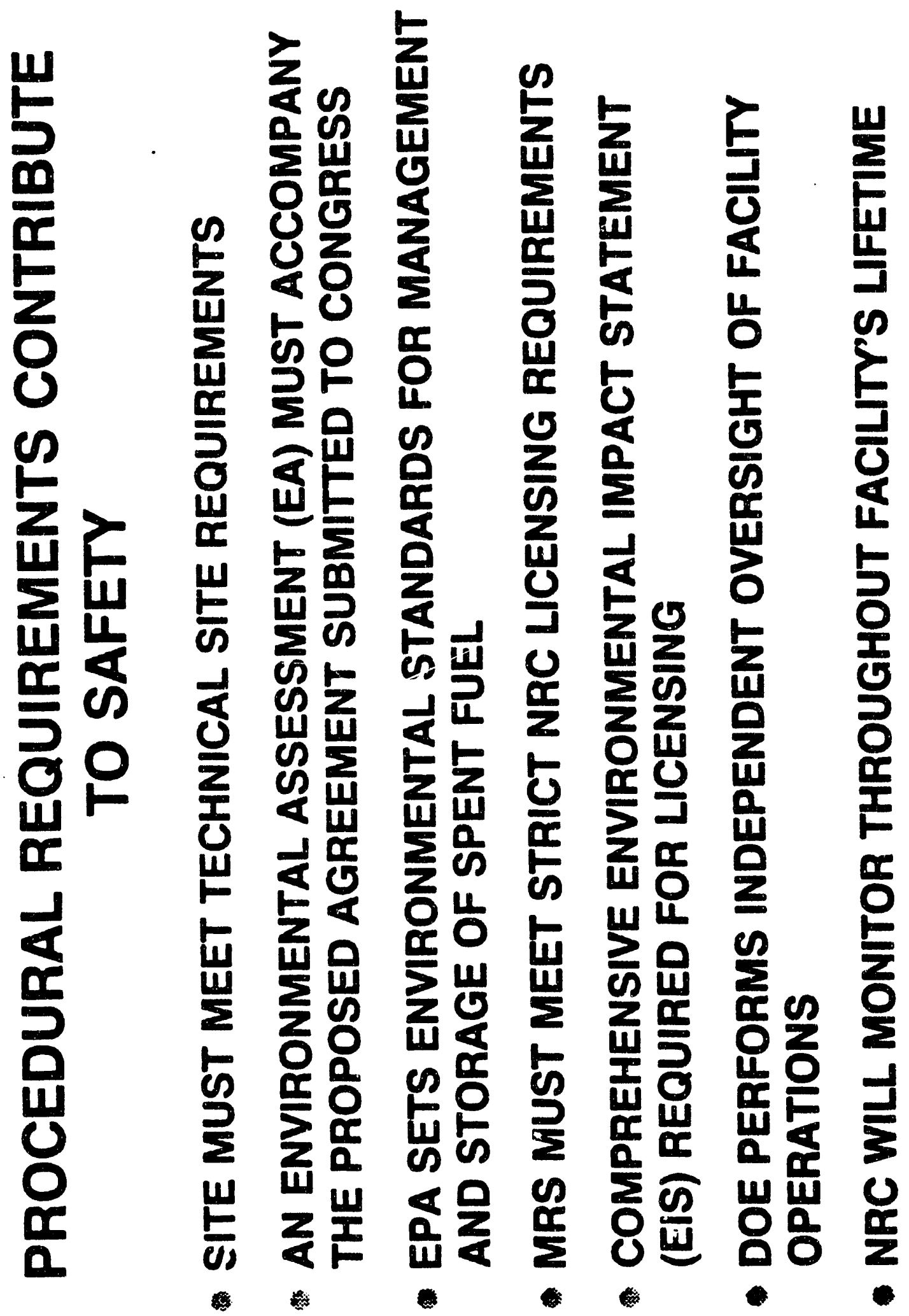




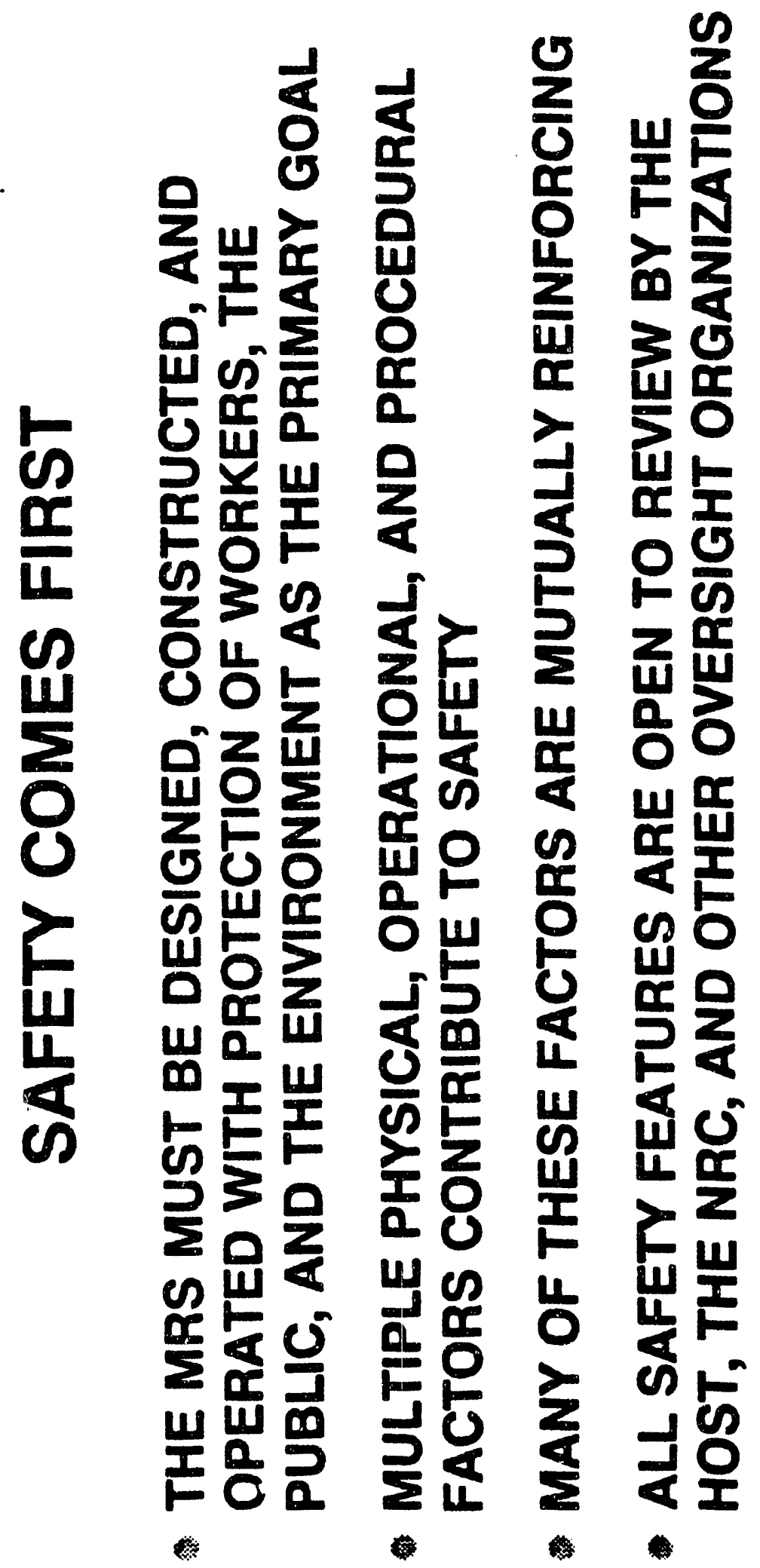




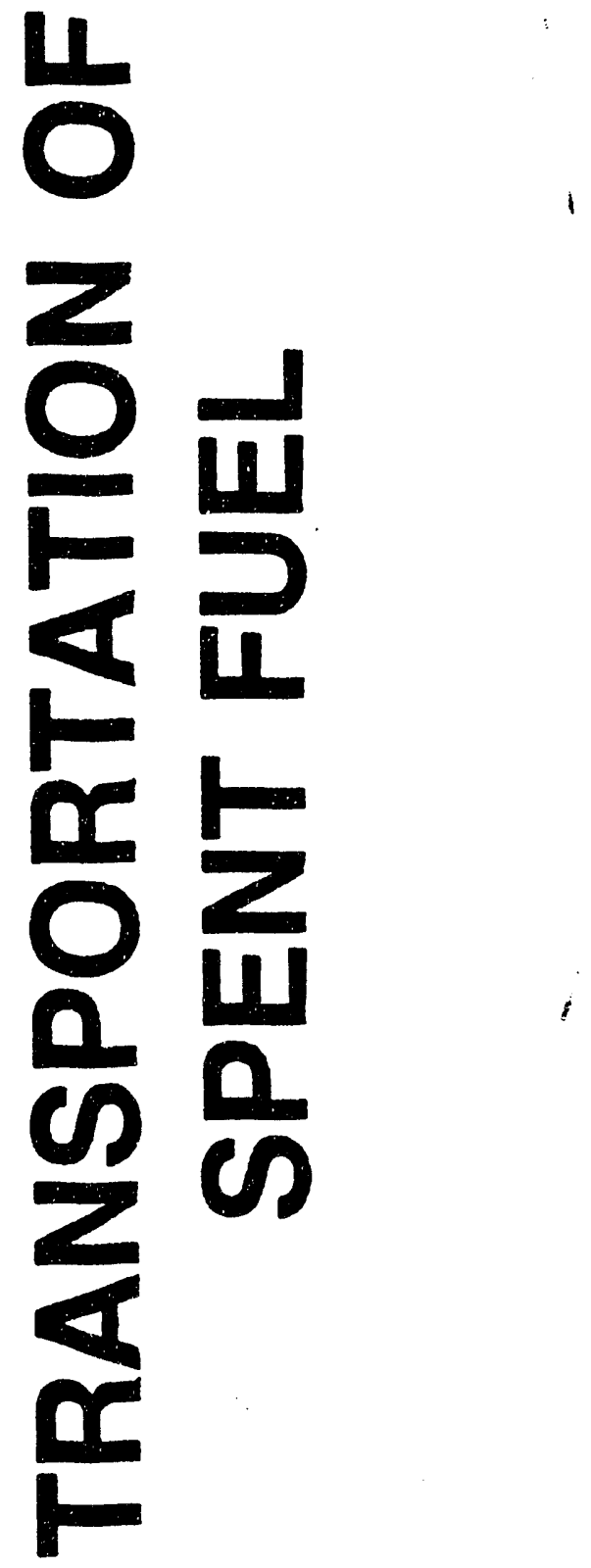



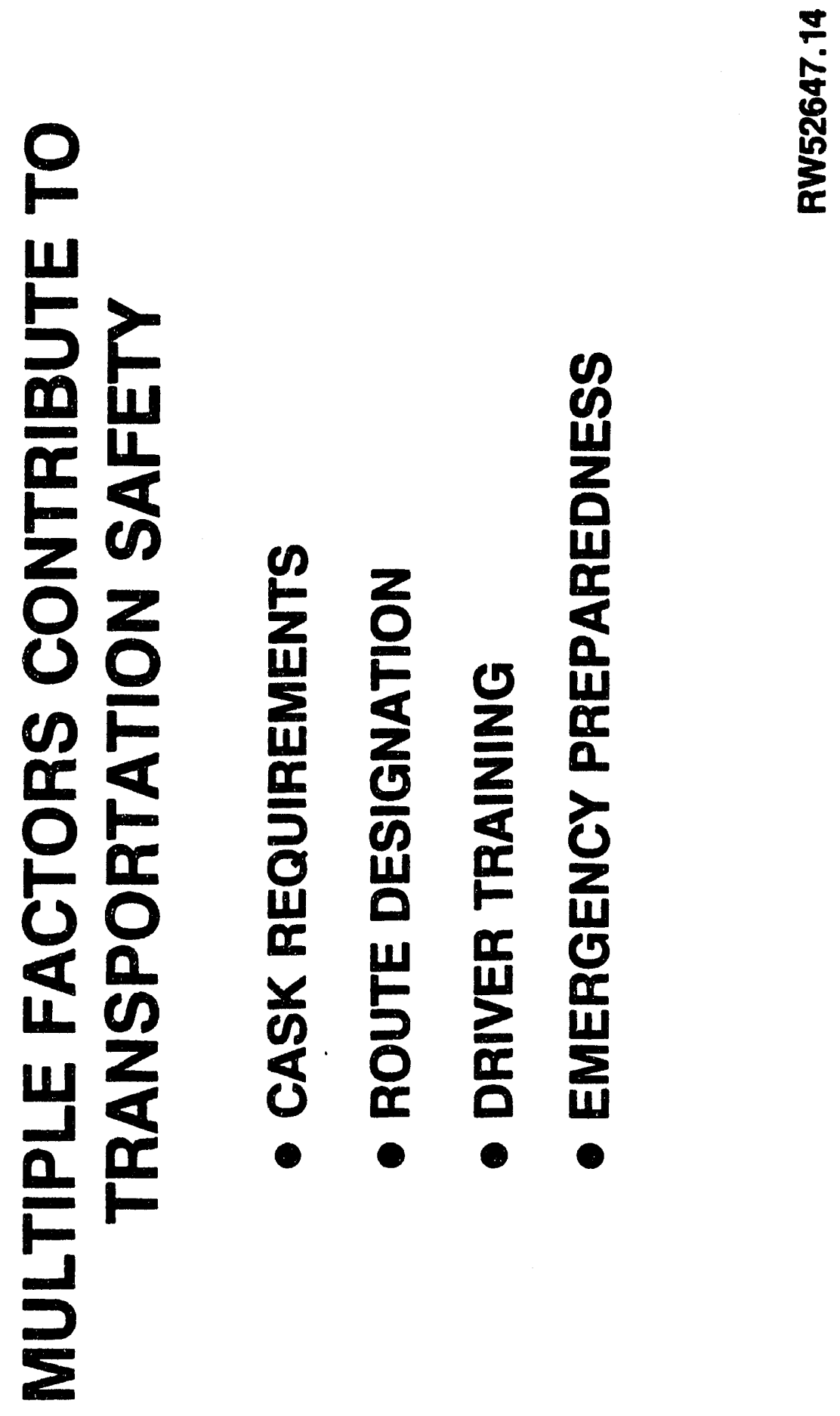


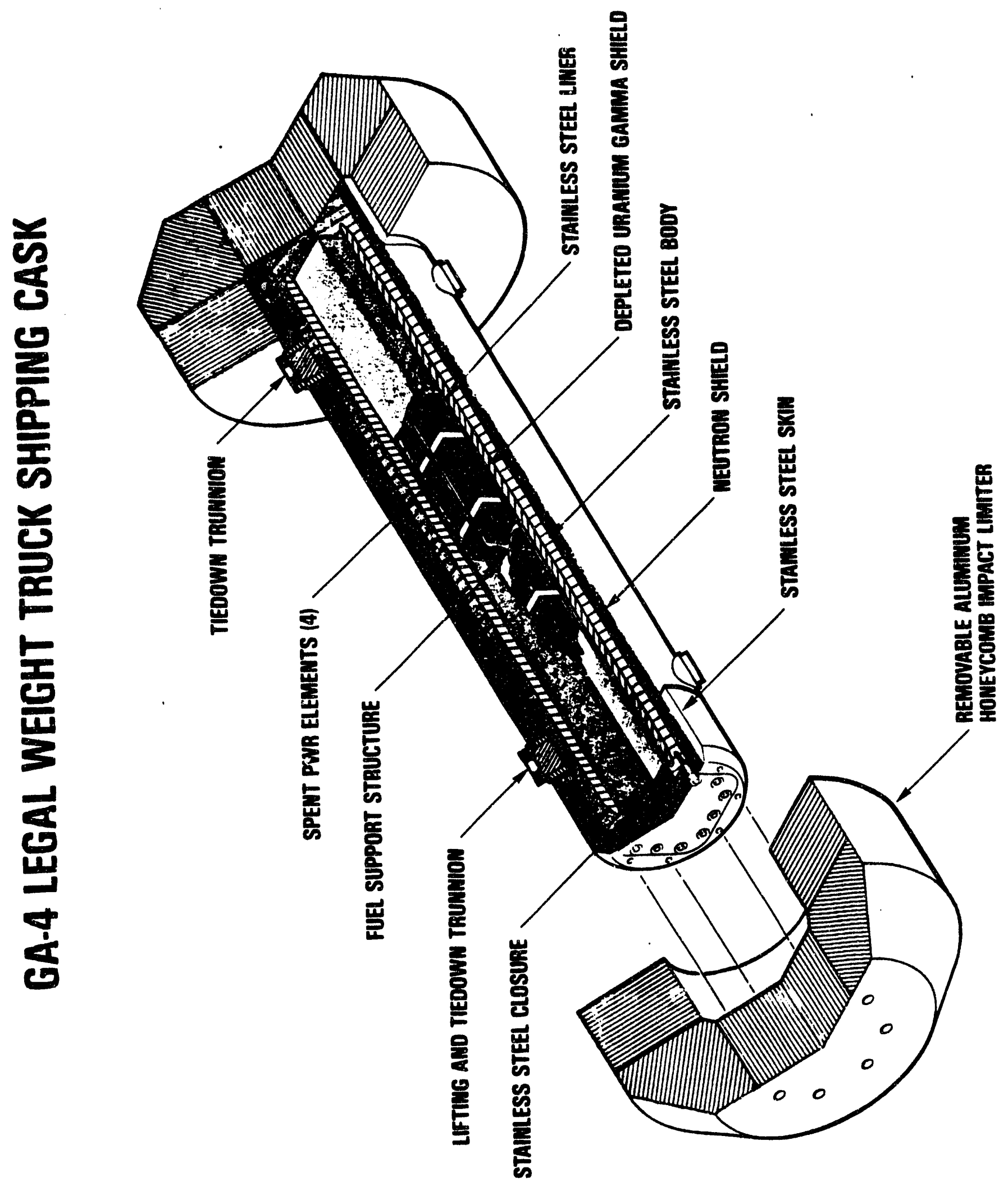




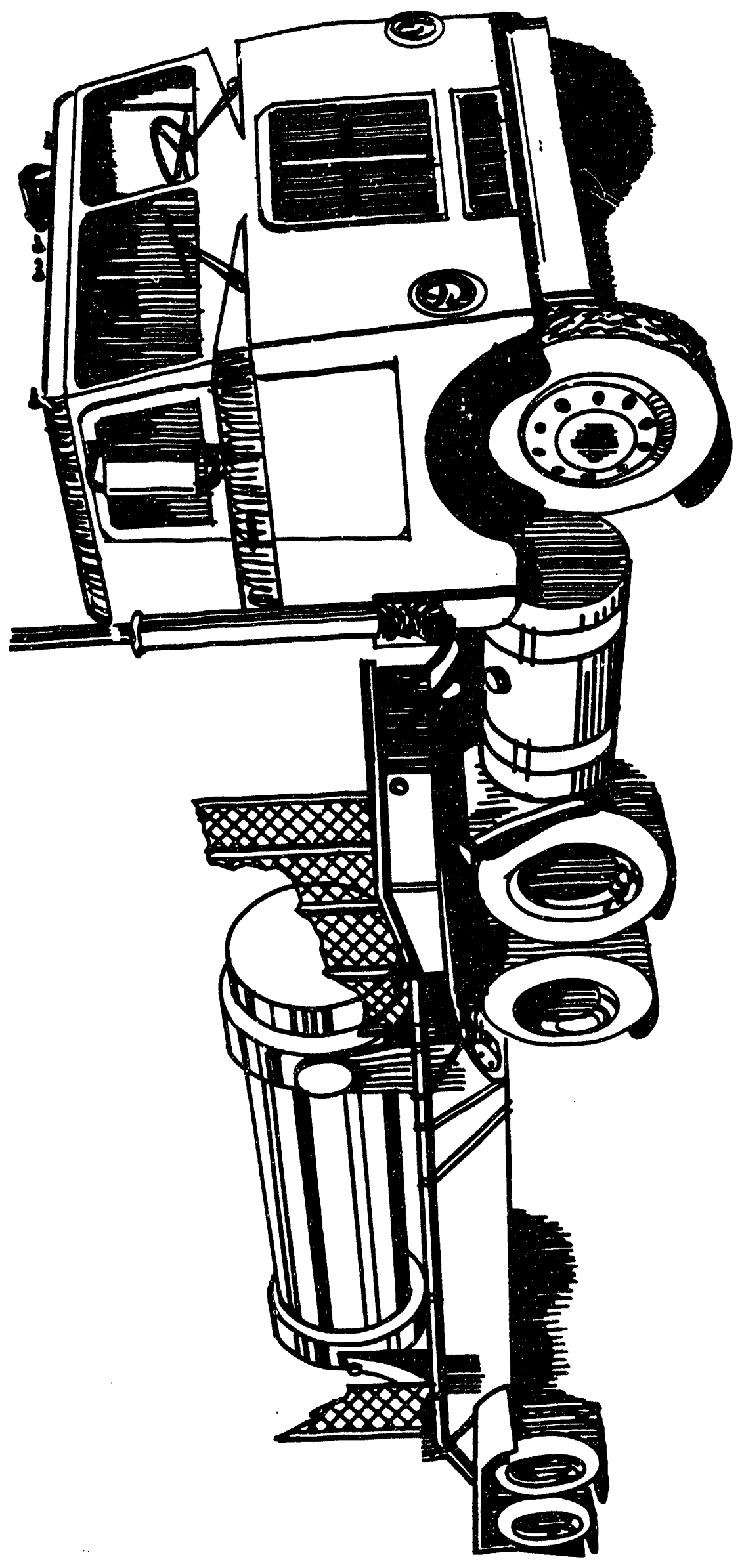




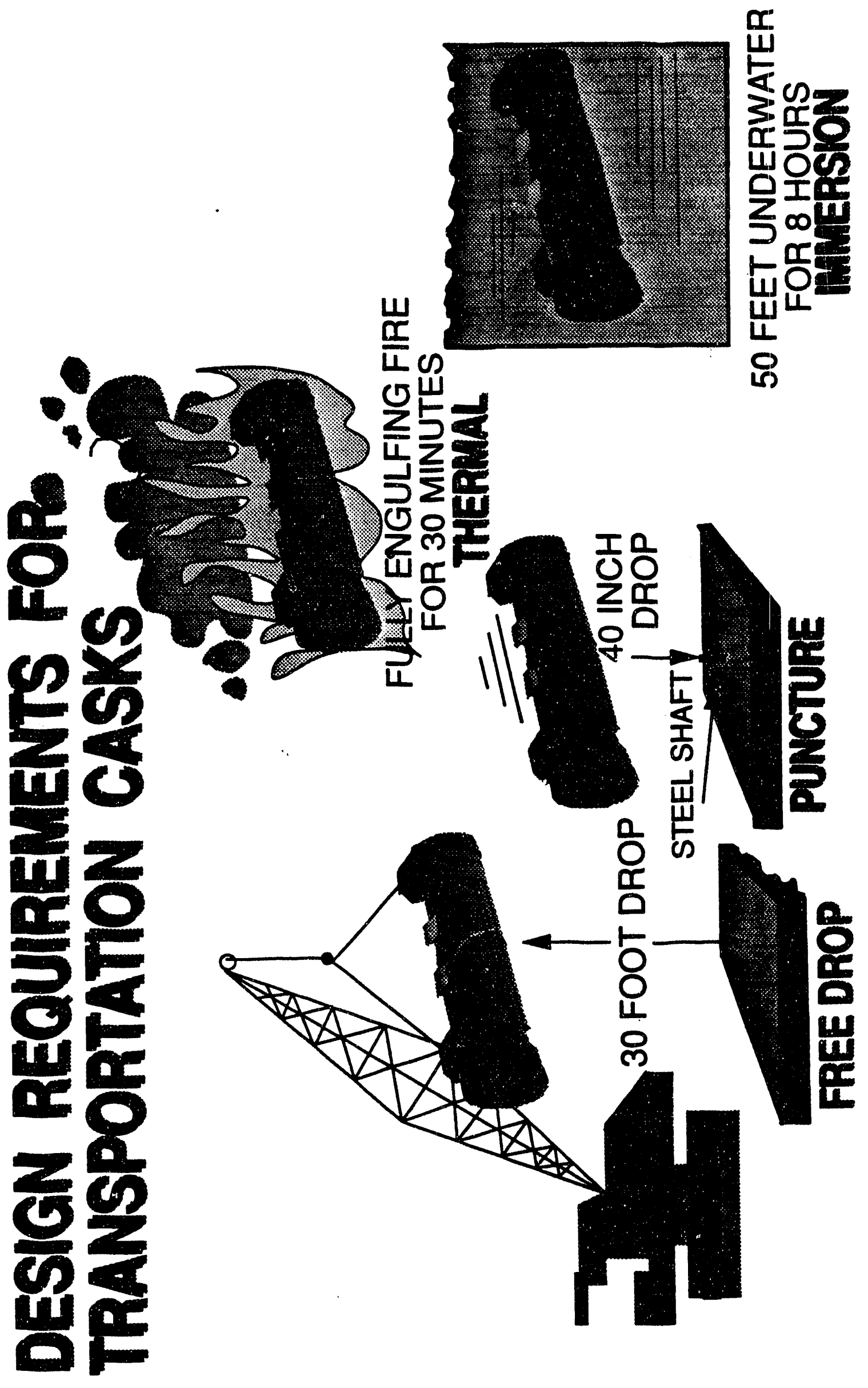




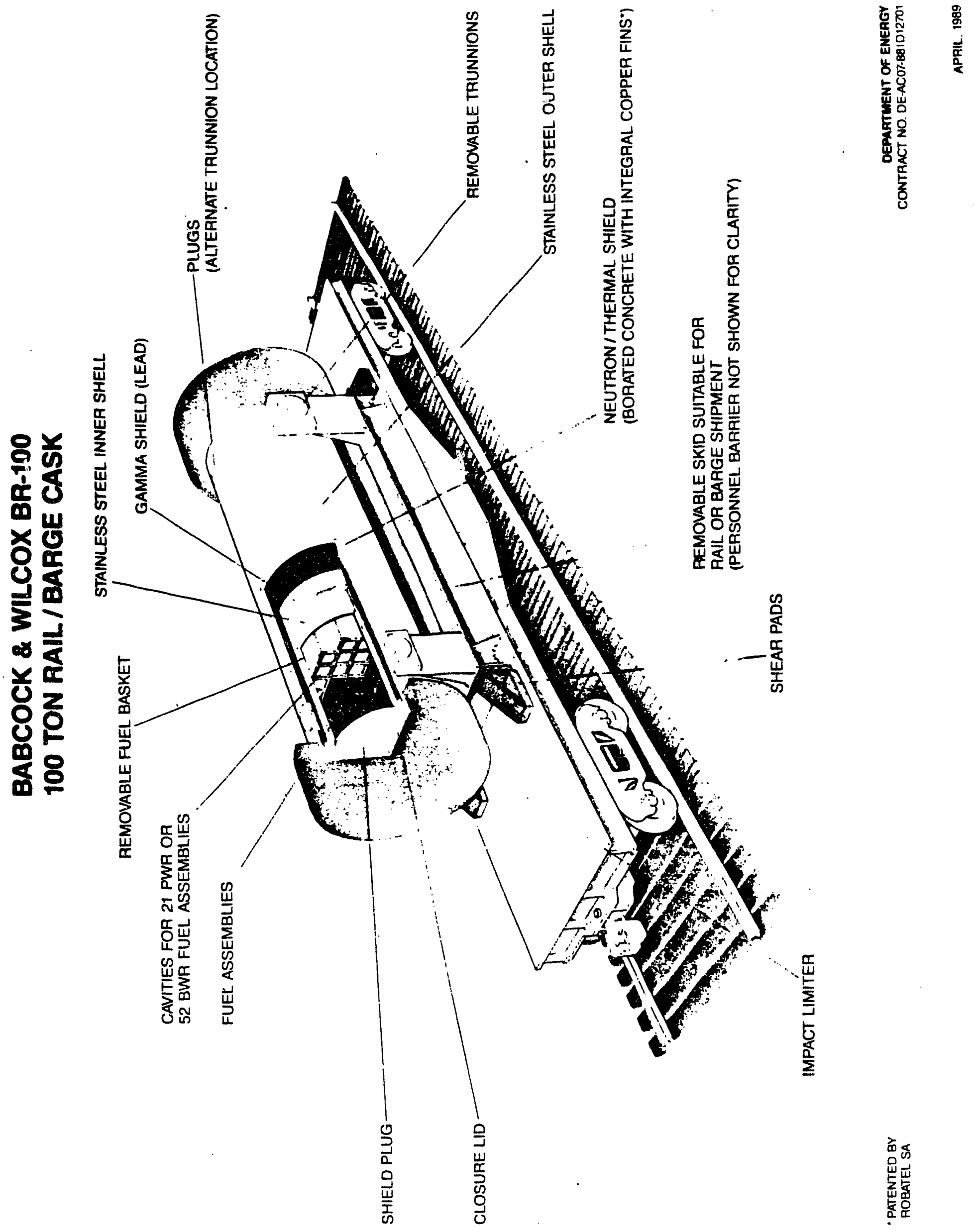




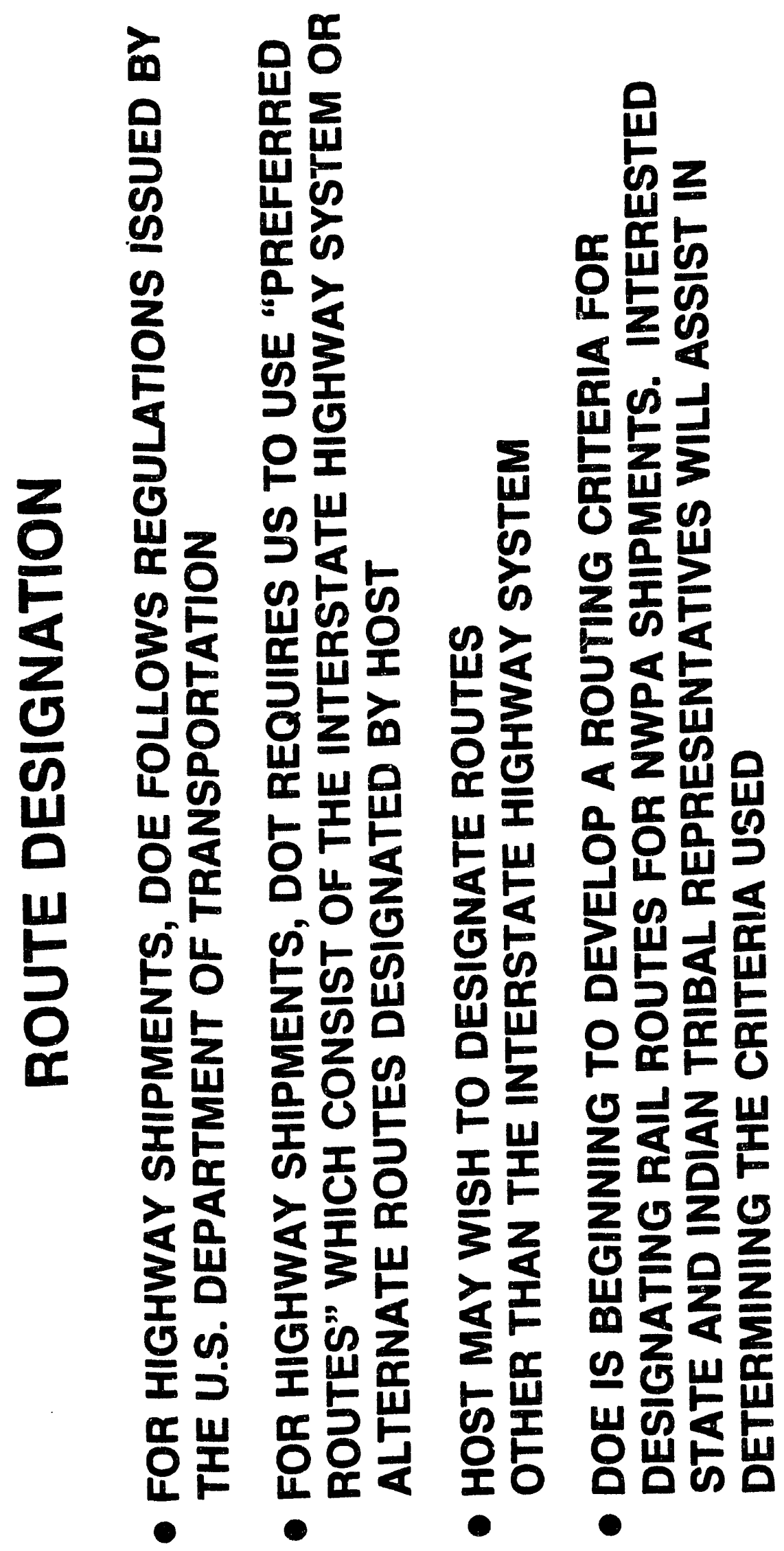

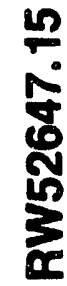




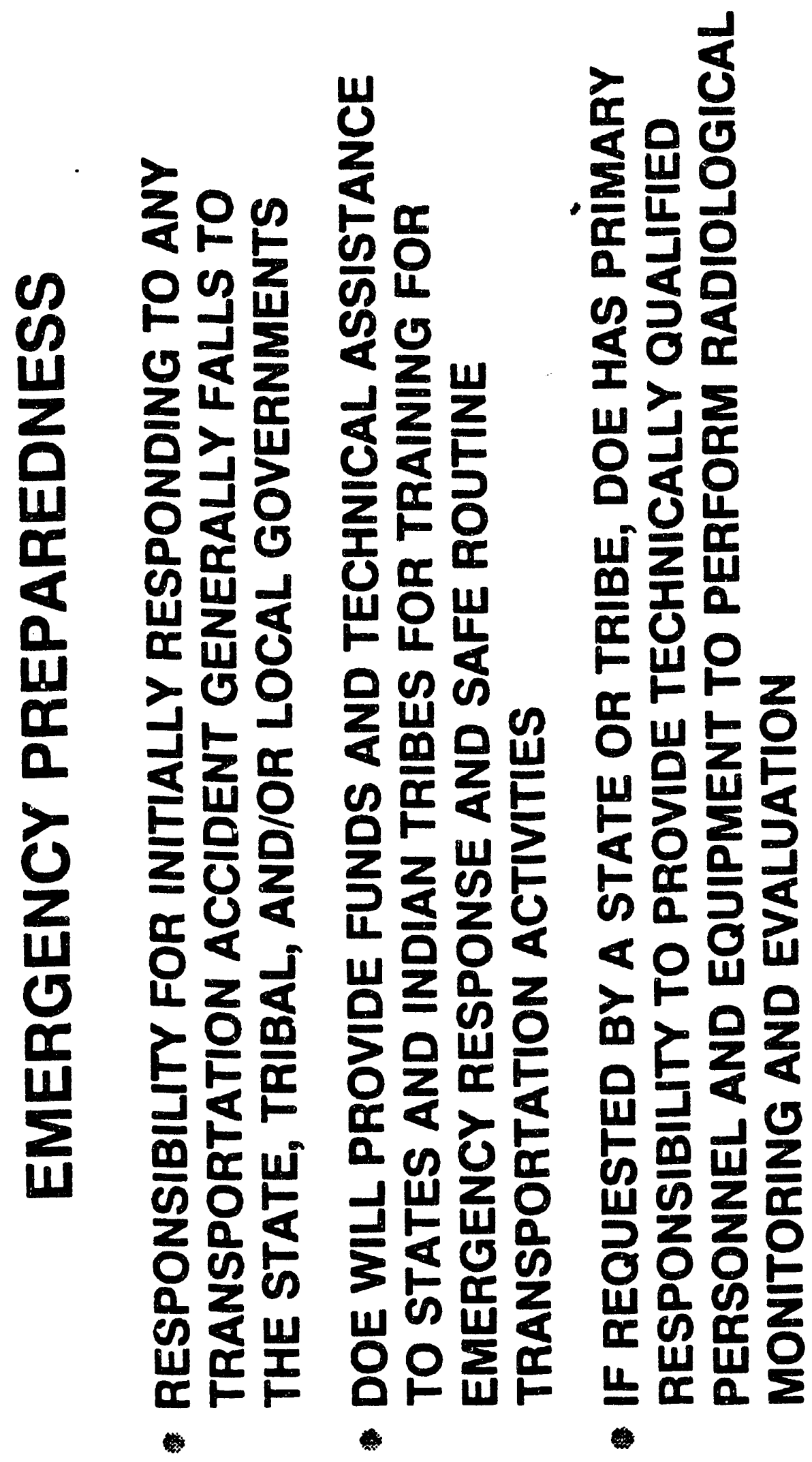




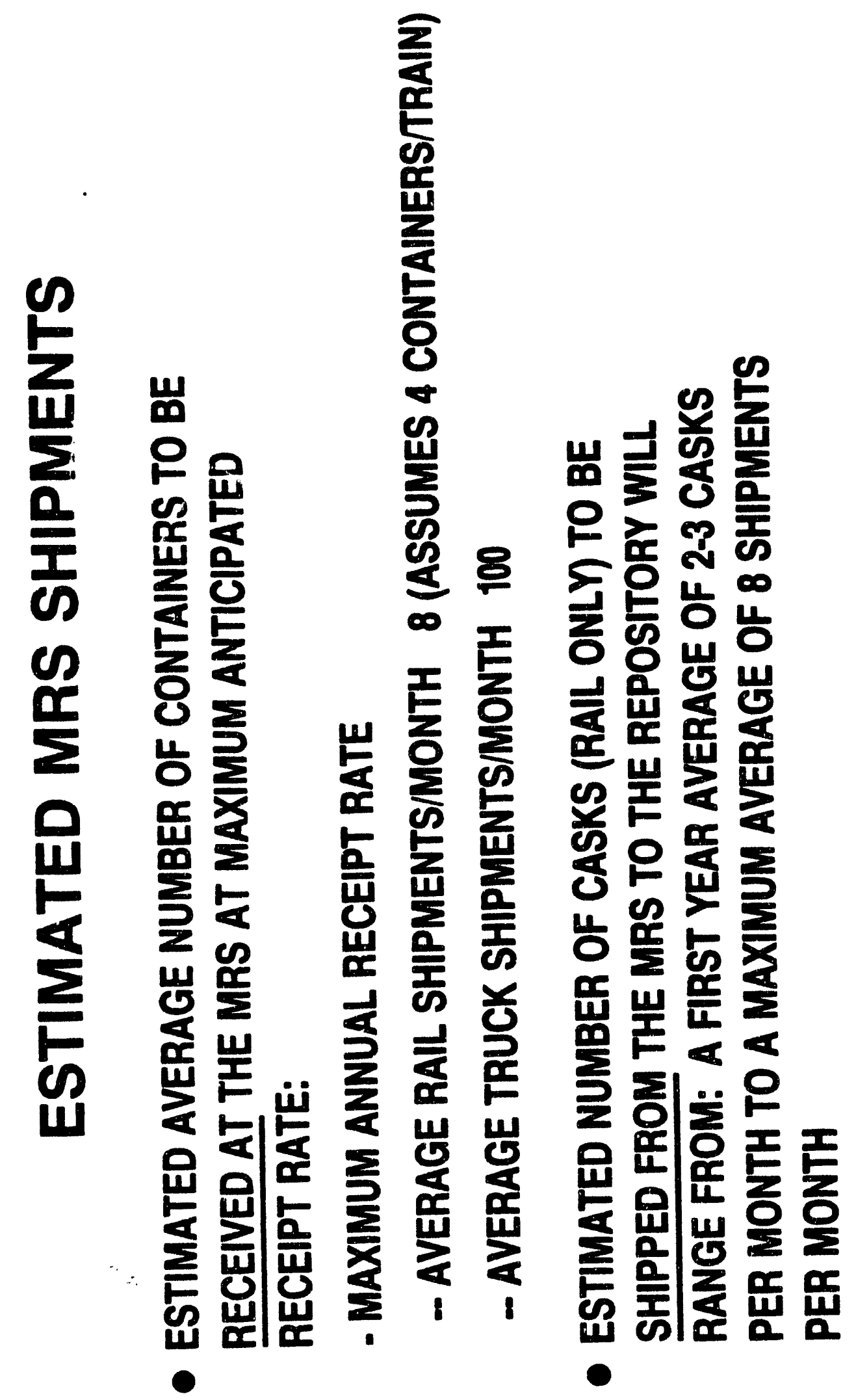




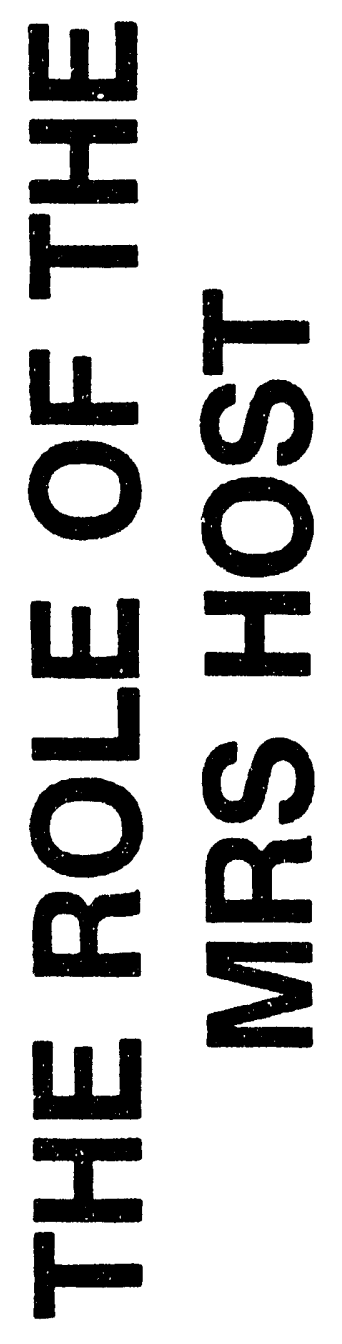




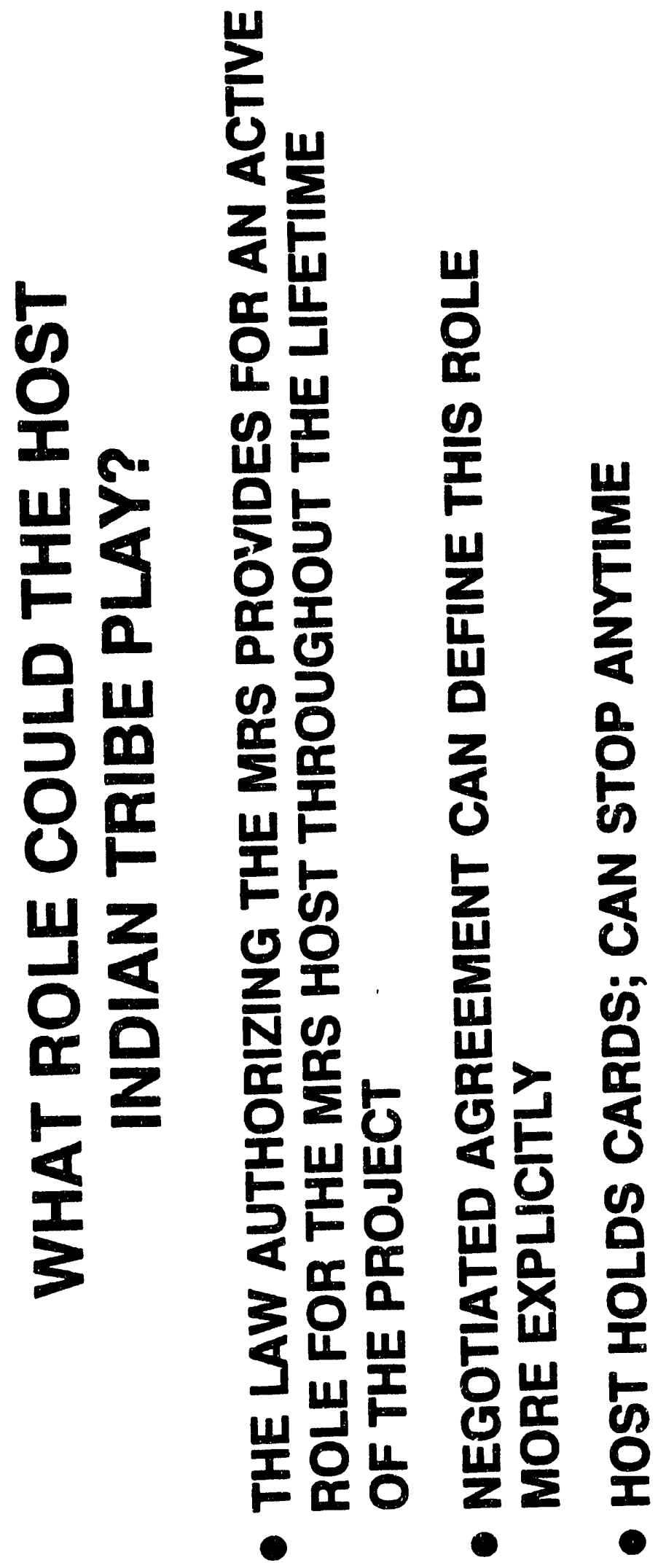




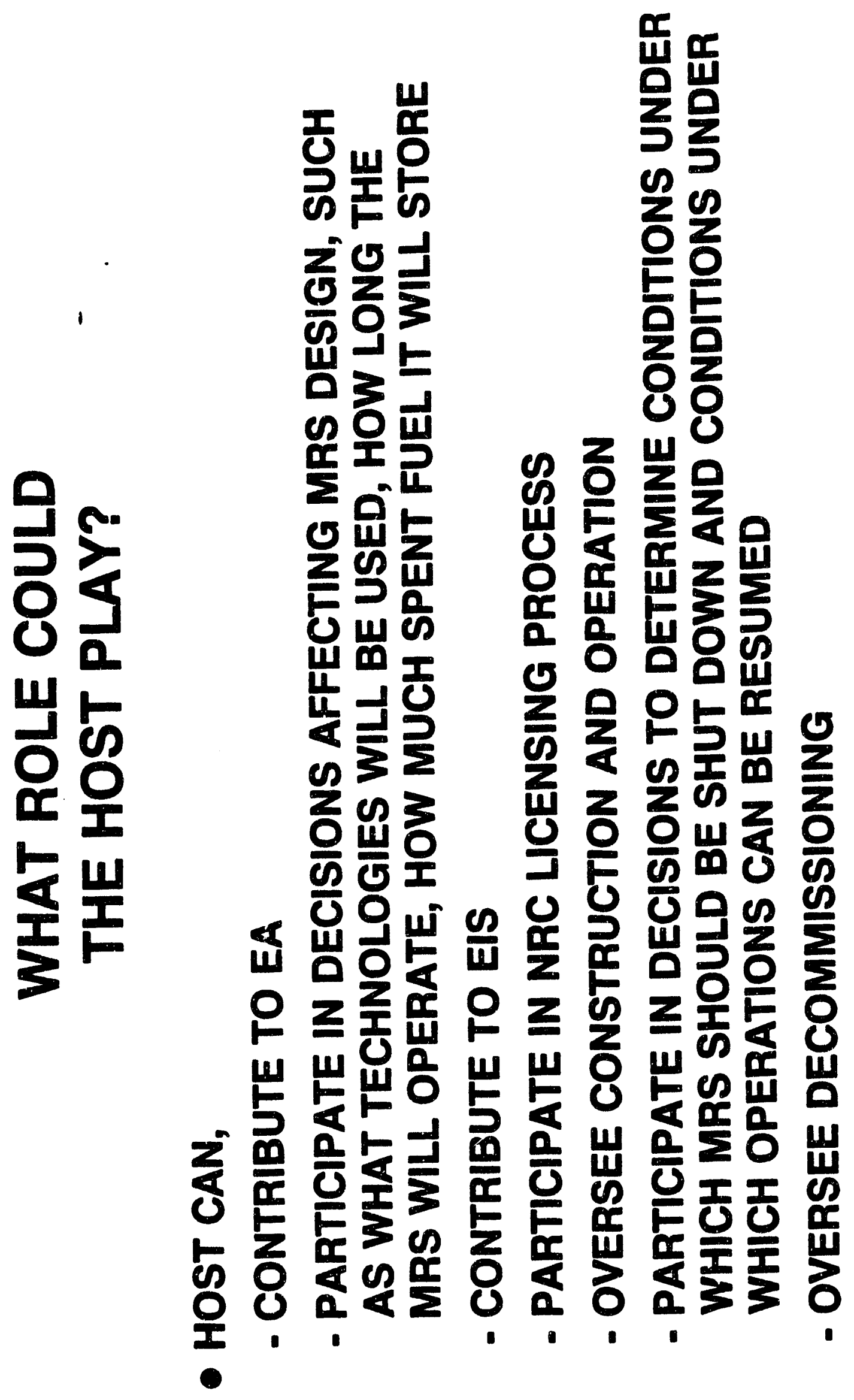


FRED W. QABOURIE, Sr.

February 24, 1993

Ponca Industrial Corporation

P.0. Box 154082

Irving, Texas 75015

Gentlemen:

It is a pleasure to have been a service to your corporation concerning matters pertaining to Phase I of High Yield Nuclear Wast Repository and/or Temporary Monitored Retrievable Storage.

It is my intention to continue as legal counsel to the conclusion of the entire project.

Within the next several days I will forward my budget for Phase II thereof.

I believe it is extremely important to have a conference concerning the management and direction of the project. Please advise as to date, time and place convenient for the meeting.

very truily yours,

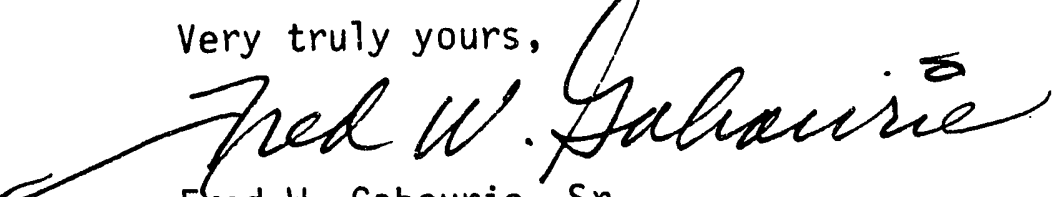

Fred W. Gabourie, Sr.

FWG/ $1 \mathrm{~g}$ 


\section{February 18,1993}

Mr. John W. KIng

Ponca Industrial corporation

P. O. Box 154082

Irving, TX 75015

Dear Mr. King:

Pursuant to our conversation on February 13, 1993, we are submitting the following proposal and budget for your review.

The proposal outlines in very general terms our contributions as we see them relative Phase II-A of the MRS aubmission. We, of course, are very wililng to work with you and your colleagues to define more specific task as the approach 18 more clearly defined. In addition, it 18 our assumption that if additlonal effort over and above those estimated are be required, we can extend the budget estimate. The budget also includes funds for travel but we have not defined the locations speciflcally. However, based on our conversations, it appeared that some travel mlght be necessary. We look forward to work1ng with you.

If you require additional information, please do not hesitate to contact us.

Best personal regards.

sincerely,

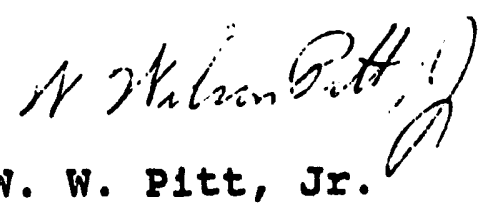

Adjunct Professor and Ass 1 stant Head

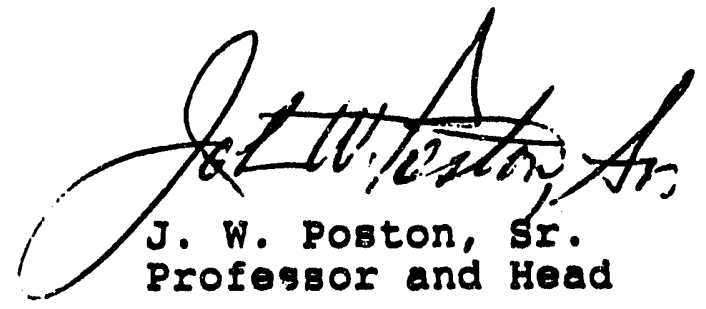


February 18, 1993

Mr. John W. King

Ponca Industrial Corporation

P. O. Box 154082

Irving, TX 75015

Dear Mr. KIng:

Th1s letter 18 to serve as a confirmation of our willingness to serve as Sclent1f1C Adv18ors to ponca Industrial Corporation in the matter of the Monltored Retrievable storage Fac111ty.

As we discussed, enclosed for your review 1s the resume of Dr. P1tt.

If you require additional information, please let us know.

(i) $\sqrt{2} \sqrt{2}$

initis 01 igrj了

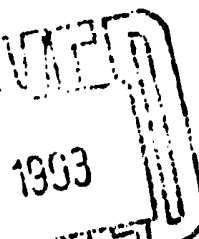

sincerely,

if vilim oniti

w. W. P1tt, Jr.

Adjunct Professor and

Asolstant Head

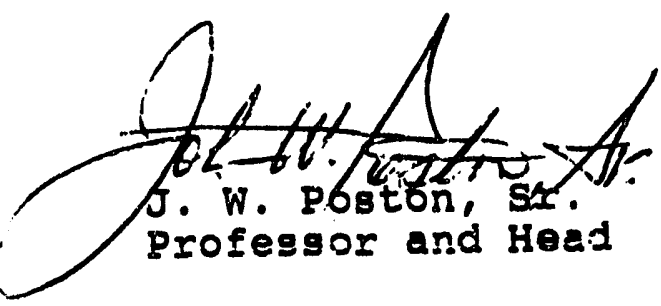


-

OFFICE OF THE

UNITED STATES NUCLEAR WASTE

NEGOTIATOR

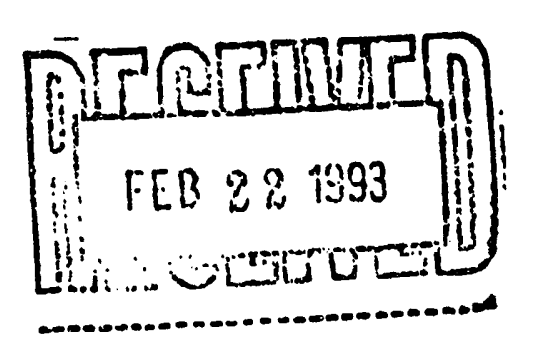

DAVID H. LEROY

INTOOTINIOR

J king

Anne Industrial

$2 \cdot 18.93$

Dos In:

Thanks for your letters of February 11 th. Your statements of appreciation and support ane acknowledged and valued.

As to yous regents regarding the Grant Prows:

1. DOE through. Alter Bunsen wort ld be the proper

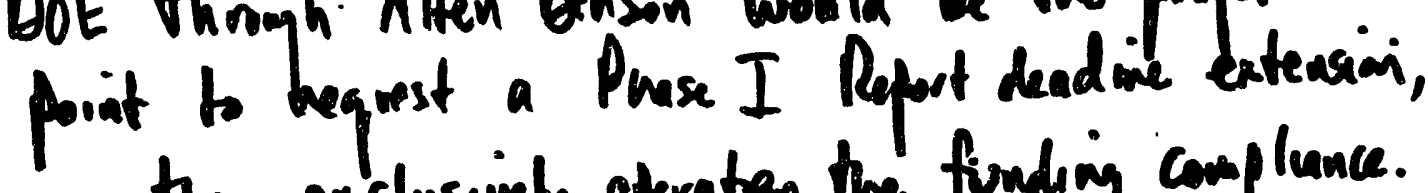
as they exclusively operates the finding compliance.

2. The Marsh 31 Pase II Appliecturs date will probably NoT be extended, Oat only a lever af in kent to apply ma format affront by BOE need be actudth filed by that date. Verify, with Benson.

3. This office has annual re guested the these IIA funding increase to "400, oo d as you recommend.

Best

C. Allen Benson, DOE

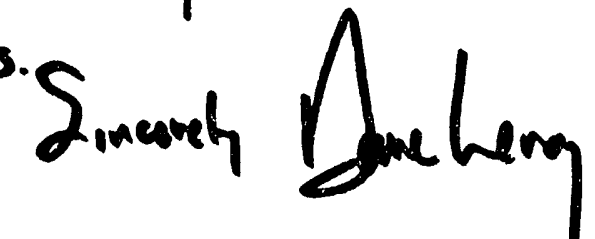

3050 N. LAKEHARBOR INANE - SUITE 100 • BOISE, ID 83703 • 208/334-9836 • FAX 208/334.9880

LIAISON: 1823 JEFFERSON PLACE, N.W. - WASHINGTON, D.C. 20036 • 202/634-6244 • FAX 202/634.6251 


\section{VAN RIDE AND QUESTIONS ABOUT MRS FUNCTIONS AND REPOSITORIES \\ James S. Medford \\ February 8, 1993}

Basically the radiation you are talking about three types of rays or three types of radiation, one being alpha radiation, another one being beta, and then the gama radiation. The Alpha is the weakest of the radiation it can be stopped by a sheet of paper, beta is a little stronger, it requires an aluminum foil or tin foil something like that, and finally the gama rays are the penetrating rays that require steel and concrete. Natural occurring you have these types of radiation everyday. Radiation is something you all don't realize but we all live with it from day to day, a normal person in the U.S. has a normal, the amount of radiation they receive in a year is somewhere around $360 \mathrm{millirems.} \mathrm{Rems} \mathrm{is} \mathrm{a}$ unit of radiation, millirems is a unit of radiation. It can be called anything tut millirems is what the scientists use it to measure by. I will just refer to it as units of radiation. The average person receives about 360 units of radiation per year. This radiation comes from a number of different sources, from the soil, from the rocks, from cosmic radiation, from everyday activity, such as airline flights, watching colored TV, standing beside our microwave when its cooking food. So, the average person receives about 360 units, and if you look at the NRC has regulations about how much radiation the public can receive, additional radiation the public can receive by living next to a Nuclear station, and that regulation states that if someone wants to sit on the boundary of the nuclear plant or facility, then they could receive no more than 25 units of radiation within one year. That means that person sits there 24 hours a day, 7 days a week, 365 days a year. If he sits there the whole time, he would not receive more than 25 units, that is the regulatory unit, the actual unit that is measured at these reactors at the plants and facilities are considerably less than that. Sometimes you are talking somewhere between one additional unit if that person sat there on that fence for a whole full year he would receive only one additional unit of radiation, so it is really a small, insignificant amount of additional radiation by living next to a nuclear plant. There is also some strict requirements for the workers who work at the nuclear facility, there are regulatory limits on how much they can receive, the facility is always monitoring these individuals to make sure they don't exceed those safety regulatory limit. It is a very controlled type of work environment to ensure that you don't go over the so called safe limit that exists. I guess, let's step back a moment, let's put that one unit of radiation or that 25 units that are allowed, into perspective. Basically if you took an hour flight across country 
you would receive about 3 to 5 units of radiation flying across country basically because you are closer to the sun, you would pick up the additional 5 units of radiation. The normal x-ray, if you had a medical $x$-ray you are somewhere in the 5 to 10 units of radiation, additional radiation would come from something like that. As you can see, it is a very small amount of radiation that would be received.

How much radiation would it take to kill you?

A normal lethal dose of radiation is somewhere between 500,000 to 1,000,000 units of radiation is what is considered a lethal dose, if someone was exposed to that much radiation, then the chances are that they would die within a few days. There is different levels of radiation, we are talking normal of what has been measured at nuclear facilities is somewhere around one unit of radiation at the boundary of the sight. The legal limit for that boundary is 25 units of radiation. You and I receive normal background radiation, somewhere in the 350 to 400 units per year. If you go up, you know when they are treating cancer and giving chemotherapy, chemotherapy is a form of radiation and a normal patient who is exposed to the chemotherapy treatment, they receive around 100,000 units of radiation. There are some noticeable results because of it, they may lose their hair or become sick. So, in this case it is not a lethal situation in this case, they do recover, so that is 100,000 then when you get up to 500,000 to $1,000,000$ units of radiation that is when you receive or approach the lethal amount of radiation. That is a wide range. There are ways to control radiation and it is basically by the concept of time, distance, and shielding. If you have a radiation source, and which you certainly know it is there when you are a worker at a nuclear facility, then what you do is you stay away from that source, unless you have to be in the area. If you do have to go into the area, you distance is important, the further away you stand the radiation does dissipate quickly. Also, you can put something between you and that source, whether it is protective clothing workers may have to wear to mavbe rapping up pop in lead blankets if there is a radiation source in that pop. There is just a lot--time, distance, and shielding is the basic philosophy on how to go about protecting and shielding yourself from radiation.

How long does this stay in your system?

Radiation is in everyone's system, everybody has radiation to associate with. I am receiving radiation from you by just sitting in the car with you. If you are exposed to some types of radiation may stay in your system longer than others, it just varies on what type of radiation that you might have in your system, but that is one thing that these facilities--and $I$ am sure you will see it tomorrow--when you go into the facilities they will put you in some equipment, it is called a body burden analysis, basically what that does is you will go inside this room and they have these detectors and they will basically check the radiation you have in your body when you go into the plant. When you come out, you will go back through that facility and they'll go check again and then you can see the difference. What we will be doing and what--there is no real change in a persons--it is just a safety precaution--a way to document that no one picked up any internal radiation or 
contamination while they were inside the plant. It is, the workers are closely monitored that would be working around some of this material. plant?

Why do people always acquaint a nuclear bomb with a nuclear

I think a lot of $i t$ is the perception of nuclear, I think overall that nuclear industry may have been guilty of not promoting, not having an outreach program so that the general public could understand what a nuclear facility is. I think it is just a nuclear perception that people automatically draws when you say something nuclear. I think it goes back to people's minds, nuclear bombs, and things like that, but the commercial nuclear industry is definitely something different. There is no way that spent fuel can explode, blow up, or anything like that, like some people look at a nuclear bomb, and think here we are talking about the same thing. It is totally separated and I think the biggest problem is just the level of understanding with nuclear and. .

What plan of the United Stotes handles nuclear military and weapons? Storage?

There are several defense installations around, Savannah River Plant in South Carolina, the Hanford Plant up in Washington state, the Nevada test sight in Nevada, there are several others but nothing that will be--the spent fuel that will be at the MRS itself will be only from the commercial nuclear reactors in the U.S., there will be no defense type waste that will be stored at the MRS, and all of the spent fuel that will be stored at the MRS is solid there will be no liquid waste of any type stored. It is all solid and above ground, it will be in the same geometrical arrangement, it will be in the fuel assemblies will be intact as they are before they go into the reactor.

So if they had an accident, say a plane crashed into one of the atorage facilities, you could contain that immediately.

Yes, in some of the design perimeters are such that they would encompass something such as a crash. The facility may not be designed directly for a crash but some of the sizemic perimeters or the missile perimeters that, that is the design basis for the storage units themselves, could encompass or could envelope the impact of a plane crash and it would not split apart or release the radiation. Again if it did, you have your time, distance, and shielding and there is some safety, you have buffers all around the facility to ensure that the radiation does not get offside any harmful doses.

Is there such thing as an ideal storage facility?

Well we think the MRS is one. I mean it is a very passive facility, there is no high pressure systems involved, it is not a complex facility, it basically serves three or four functions: to receive the spent fuel, to store the spent fuel, to retrieve the spent fuel, and to transport the spent fuel to the final repository. There is no real systems that so forth, there is no effluence that will be released from the MRS's facility other than your standard effluence that you have with any industrial complex, the sewage the water, there is no processed type of effluence that will be released from the facility.

If we can jump back a little bit, now those military 
installations, are their storage facilities different from a commercial MRS?

Yes, a lot of the military and a lot of the waste is stored at the military facilities or some (??ice liquid??) place. If the liquid place has now been solidified through a process called verification, this is basically where you mix the waste, and then through a process make glass logs out of it, and the waste is then encapsulated in the glass log. Also, the military storage facilities do not fall under the NRC the nuclear regulatory commissions authority or oversight. The MRS facility is the first facility in which DOE has developed which could be licensed through the NRC, and this licensing means that the NRC will oversee the development facility, this includes the design, the sight selection process or the sight characterization process, the construction of the facility, the operation of the facility, and the commissioning of the facility. So, the NRC will be involved in the regulatory role oversight all through the life of the MRS facility. This is something that is never been done before for a DOE facility before. The IRC has been the regulating body for the commercial reactors for the last 30 to 35 years and the commercial reactor industry itself has an exemplary safety record and they are very stringent and fair organization. Their sole purpose is to ensure the safe operation and development and decomminishing of the nuclear facilities. The take their role very seriously.

Explain about turbine, nuclear-turbine energy.

Basically, the way nuclear energy is produced, the way you produce electricity is to make steam, and the steam is used to turn the turbines. There is different ways to make steam, coal plants make steam by burning coal, heating the water, making the steam, turning the turbine. A nuclear plant uses the heat from the fusion processes, when the fuel assemblies are in the reactor vessel, and the conditions are such that fusion begins, then as these fusion particles, as fusion goes on then it produces heat, as the neutrons collide with each other, then heat is produced. When you get enough of these collisions it produces enough heat, that it will heat up the water that circulates around these fuel assemblies. Now, the water that circulates over the fuel assemblies is not allowed to boil, it is kept under pressure and the heat is transferred to the water and it goes above the boiling point-inside a reactor vessel you could typically be looking at 600 degrees fariegnhieght--but the water would not be boiling. That loop of water is continuously circling around, it is called the primary loop, it circulates around and goes through in the pressurized water reactor. This primary loop of coolant we call it, it is around the fuel assemblies themselves goes through what is called a steam generator. A steam generator is just a big vessel that has a number of small tubes in it. This water is circulating through the small tubes, now there is a secondary group of water that is also circulating through the steam generator. That loop of water is not under high pressure, and that water heats up and turns to steam. Now that steam is fed through what is called the turbine. The turbine is like a windmill, as the steam goes across the turbine blades it causes the turbine to rotate, and as the turbine rotates it turns what is called the generator, which 
is just a lot of coil and magnet and it produces electricity which is sent out over the transmission lines to the customers and so forth. Then this loop of water, this secondary loop of wates that goes through the turbine, turns the generator, and is cooled by a third loop called the coolant loop, which is water brought in from a lake or the river or wherever the plant is located. This water circulates around the--it goes into what is called the condenser, and then the condenser the secondary coolant loop and the outside coolant loop circulates in the condenser and it cools that water back down that has been heated up in the secondary loop, and then the coolant water from the lake is discharged back into the lake and then the secondary loop goes back through the steam generator and the heat is transferred and steam is formed once again. So, there is basically three loofs of water: the primary loop inside circulating around the reactor vessel into the steam generator, the secondary loop which circulates through the steam generator, turns the steam, goes through the turbine, goes to the condenser where it is cooled by another loop of water that is from the outside from the lake or the river which condenses the steam back to water and then it feeds it back into the steam generator.

Now, you know that first MRS concept you explained yesterday, it was $-I$ forget the name they called it-it seened like it was parallel, I forget the name. The type of storage.

Horizontal storage modules. Right now we have just completed what is called the conceptual design phase for the MRS facility. During this phase, what we concentrated on was the existing technologies that were licensed that could be implemented--existing storage facilities that were licensed--have a proven safety record which could be used at a MRS facility. There are six such storage technologies available: the concrete vertical casks, the metal vertical casis, the horizontal storage module, the modular vault method (used at Fort saint Brain), transportable storage canister/casks, wet pools (used at reactors today). All of these storage technologies provide a safe and efficient way of storing spent fuel. At this point in time, no decision has been made on which one of these storage technologies will be used at an MRS facility. Ore of the reasons that this decision has not been made, is that we wculd like for the host to have some input to which one that they feel most comfortable with, the one they think that the community would benefit most from, so right now EM would work and it is just a matter of waiting until a host will show us or indicate which preference they may have.

What are the NRC specifications for a MRS type?

Basically the NRC really doesn't get into how thick the concrete has to be, they give you the requirements on what the facility has to be designed for. What scenarios you have to look for is your design base, the earthquakes, that is south pacific based, or whether your facility is based you have to design a facility so that the worst possibie earthquake would not damage or result in losses of radiation off site. You also have to look at things such as missile impacts. These things are the type things that really dictate how thick the concrete. The NRC says you will design this and in doing that design you will come up with the thickness of the concrete. Also, the thickness of the concrete is 
set by shielding purposes if you are inside a transfer facility for the actual thickness of the wall from an earthquake standpoint may only dictate a one foot wall but because of shielding exposure and so forth that may dictate a three foot wall. NRC gives you these guidelines as far as what the facility must be designed for and gives you guidelines as far as radiation control and allowable iimits for workers and for the public safety and health, so that is what sets the thickness of safety for the walls and such.

The basic concept of an MRS then would be to receive, store, and transport to a permanent site.

That is correct. They will be monitored all of the time. There will be radiation monitors that will be placed permanently around the facility, plus you will have some monitoring going on-individuals may go out once or twice a day and have a hand held monitor where they would be monitoring a select areas of the plant so monitoring will be done continuously. These records are kept and they are reviewed by everyone from the host, the state, the NRC, the owners of the facility, so these records are kept and closely watched. That is another thing with this process, the negotiating process we have now, it gives an avenue for the host to have a lot of input and oversight to the operations of the facility. In developing these negotiating agreements, you could basicaliy dictate what type of oversight you wanted. You may want an independent group whether it be a university, or a local environmental farm, or whatever, you could have them also do monitoring at the facility and checking to satisfy yourself that everything is operating correctly, that could be an additional level oversight that could be negotiated into the agreement.

Where is the headquarters for the NRC?

The NRC is based in Washington D.C., they have an office that is up in Maryland, it isn't far from the D.C. area and that is definitely someone that we have had other grant applicants who have been interested in the feasibility in hosting an MRS facility. WE have taken field trips to the NCR and allow you to discuss their oversight role and that is something that is certainly an option in this case.

Is there any way that you can contact the NRC and tell them that we are interested in it?

Oh, yes, and the NRC is willing to work with us and set up these tours. At any time let us know and we could set these up.

They have a manual, is there any way we can get a copy of their rules and regulations?

Yes, and they publish what is called the Code of Federal Reculations. This is where most of their rules and regulations are, and for the storage part of the MRS, the applicable rule is 10CRF72, and that is something I can get to you. It says that they are viable for the storage facility and the regulations it has to meet. I will get you a copy of that. A 10CFR72 covers a storage, 10CFR71 covers the transportation aspects of spent fuel, there is different regulations and rules for the two areas.

of course, we would have to get in touch with the EPA also.

Yes, the EPA and the NRC work together on some of the environmental type regulations, but the EPA does set the environmental regulations that are there in place, they set most of 
them really.

Does each state have an EPA and NCR office?

No, basically each state doesn't have an NCR office, and as far as I know they don't have an EPA. The NRC will serve, let's take the MRS for example, it is anticipated that the NRC has regional offices, they divide the country up into about eight regional offices to ten offices, but then in those regional offices they have direct responsibility for the nuclear facilities in their region. During the development in the MRS facility, you would have a lot of interaction with those regional offices as well as with the headquarters which is based in Washington D.C. The headquarters in Washington is where the license application is submitted, and that is where they review the license application--I will get to the license application process in just a second--so, you will be dealing with both the regional office and the headquarters office in D.C., now during the development or construction phase of the MRS facility the NRC will have resident inspectors to oversee what is going on during the construction phase. They will also be there during the operation phase to make sure that the plant facilities are operating according to their regulations. They have shut-down authority if you are not operating according to their regulations and that is it. They shut you down until they are satisfied that you have corrected the problem. So, they will have onsite resident inspectors that will be doing this. Let me digress a little, back to the licensing process. The licensing process for a nuclear facility takes a lot of time. Basically, there is a few steps you must go through in the licensing process. Right now we are not into a licensing process, once a site is identified, and a host has been identified that is willing to host the MRS facility, then we will go an do what is called site characterization activities. What this means, is we have to go and gather data on that site, environmental data, a site specific sizemic information, hydrological data, and meteorological data. We have to know everything there is to know about that site. Once that is know, we have to develop two major documents as part of the license application. One of the major documents is called the safety analysis report, it is a technical document that describes the MRS facility, how it is envisioned, you have to progress in the design phase to a level of design that you can describe in this document. The systems are important to safety and health. You have to develop this safety analysis report which is basically a description of the facility, and you have to describe how the facility will operate. The NRC will take this document and review it along with an EIS (Environmental Impact Statement), this is the impacts the facility will have on the environment, from any where from air quality, to water quality, to birds, fish, to cultural impacts on the existing community and so forth. So, these two documents go into the NRC for review. During this review period the NRC has up to 36 months to review the license application. During these 36 months there is nothing that can be done. You can not start construction of an MRS facility until the NRC has issued a license to construct and operate. Once the NRC has reviewed these documents and there is a few other documents you have your decommissioning plan, the emergency 
preparness plan, security and safeguards plan. There is 8 or 10 different documents actually submitted as part of this license application. Once the NRC has reviewed these documents, and they have satisfied themselves that this is a safe facility, and it can be operated in a safe manner, and it will not have detrimental impacts on the environment then they issue a license to construct and operate. Up until that time nothing can be done at the site itself. Like I say NRC has up to 36 months to do a review, and it is hard to say whether they will need that full 36 months or not. There is a lot of variables in there, but they don't issue a license until they have satisfied themselves that it is a safe facility. So, then once the license is issued, you can break ground and start construction on the MRS facility, and the current plan is that the initial construction period for the MRS facility is approximately 18 months, and then that construction may continue on for another year to 18 months before you have a finished MRS. That is basically the licensing process.

How long is the license good for?

The license is good for 40 years. That is the standard NRC license for this type of facility. There is the option to go in for a license extension after that 40 year license is up. This extension is not granted automatically. What you have to do is go back and prove the facility is safe to continue operating for another whatever the license extension is that you are seeking whether it is 10 years or 20 years you have to prove that it can still be operated in a safe manner during those years. Also, there is a lot of public input at this point, as far as public hearings and so forth to take into account of whether or not this facility is safe. All these are merged together to determine whether you get any license. The license process I just explained, there will be a lot of public interaction at that time. There will be a lot of open meetings where you will get a lot of public involvement where the NRC will hear a lot of issues and so forth of a community or state or whatever it may have and all of these are combined on whether to grant a license or not.

Can they revoke your license?

Yes, at any time if you are not operating at the facility in the guidelines of their regulations then they have shut-down authority where they can shut the facility down and if the problem is not corrected to their satisfaction, they can then revoke the license.

So, there is a difference between shut-down and revoking.

Yes, it is a matter of whether or not they are having some corrective actions going on. There is a distinction between the two, they give the operator time to correct any problems they may have to their satisfaction.

What if you have gone for 10 years and auddenly decide you don't want to go anymore?

Well, a lot of that is set up to you and how you set up the negotiating process. Are you talking about from a host standpoint?

Yes, That would have to be covered and addressed to your satisfaction in the negotiating process. You can't have oversight role or whatever or shut-down authority for the facility, but that would have to be spelled out in the negotiating agreement. 
So, that needs to be in there or you are bound to it.

Yes, unless the plan is operating outside the regulatory limits and at that point the NRC would have the shut-down control, but if the host wanted to have additional control then that would have to be part of the negotiating agreement.

If the host puts additional stipulations on it, like more security or thicker walls or whatever and then they quit complying with what they said, but they are still within the NRC, is that okay?

Well, if the host sets the standards higher than the NRC requirements and develop an agreement in such a manner then the facility is bound to operate under those higher standards, if not then the host could exercise their control on the facility as far as discontinuing the operation or whatever. It is all in how you set up this negotiating agreement. Could it be ahut down? Yes, I mean if you set that as a stipulation in the negotiated agreement then it could be. It would be looked at as the same type of binding agreement that there would be between them. had to?

Could the federal government just take over acility if they

The federal government can basically, you have to protect yourself the best way you can. The federal government could always declare an emergency and you know whatever and take over a facility, but I think there are better ways to protect the hosts interests and so forth in that situation during the negotiating process.

The facility that we are going to see right now, what are some of the problems that face that facility?

We are going to the Sub-Surrey nuclear station, Surrey plant as far as I know, has no issues facing them today, it is a very good plant and has operated for a number of years. I think that the plant came on-line in the mid-1970's. It has had a very good record. They are currently, one of the reasons we are going down is to see the dry storage facility. They ran out of storage in their spent fuel pool for their spent fuel and they have expanded their storage facility onsite by adding dry storage out in the yard. The technology I was mentioning ago, there is about 6 technologies in storing spent fuel today and they have chosen the metal vertical casks and these casks are approximately 18 feet in diameter and 16 feet tall and weigh between 110-120 tons, and the spent fuel is somewhere between 20-24 fuel assemblies are put inside these containers. In the fuel pool they are sealed and they are transported from the fuel pool area to a concrete pad that is inside a fenced-in area and the metal containers are sat there with the spent fuel until the fuel is ready to be shipped off site to a federal facility. It is a very passive system, as you will see when we go out there, there is no services to the facility, there is a fence around it, some lights, some powers for lights and security cameras, but other than that there isn't any active systems that is involved with the storage area. The only, probably one time a day, a personnel walks out and walks around the different storage containers to make sure that all of the air vents aren't clogged, basically all of the storage technologies used in circulating natural convection, cooling and basically all of the 
cool air is drawn the bottom and circulated around the spent fuel and is exhausted at the top of the storage module and this person will walk around and check with a hand-held monitor, he will check the radiation levels as well as ensure that these inlets and outlets are not clogged. That is basically the only activity going on out there, the spent fuel just sits there or out there in the containers on the pads.

So are we going to see two types of storage?

You will see tomorrow, we will go inside the plant and you will see the spent fuel pool, where the spent fuel is stored when it comes straight out of the reactor. You will also see the dry storage area, and the dry storage is when the spent fuel pool has been filled up, then Virginia Power had to build more storage, so instead of building more fuel pools, they decided to use what is called dry storage, and that is when the spent fuel assemblies are loaded inside these storage containers inside the pool the storage containers are submerged in the pool remote handling will move the spent fuel assemblies over and put them inside the storage containers. The storage container, when it is filled up, it is brought out of the pool, it is vacuumed dry and all of the moisture is drawn out of the container, it is back-filled with an inert gas of helium or something like that, to insure that there is no corrosion that will occur inside the container. Then it is sealed, well first it is sealed and then it is filled with the gas, and then it is moved out to this storage yard. So, the spent fuel is actually stored in a dry environment, there is no moisture or anything inside these containers.

Are those two options the MRS can have?

Yes, you could have a pool or the dry storage, but not both, what we have been looking at is just one storage at the MRS to make certain that it is compatible with the system. There is also a new initiative underway that is just getting its momentum and that is called the multi-purpose canister or the universal canister. Right now as you will see tomorrow, these concrete casks and these metal casks are big cask. They are too heavy and not licensed for transport, so under the current scenario you would have to, say at Virginia Power we were going to move the spent fuel that is in the dry storage that is in the casks to the MRS facility. You could just pickup these metal casks and take them to an MRS. You would have to take the metal cask and go back to the fuel pool at Surrey, submerge it back into the fuel pool and then you would transfer the fuel assemblies from this metal storage cask to what is called a transportation cask or transportation container that is licensed for highway transport. Once that transport canister is loaded you would bring it out of the pool and you would go through the same dry storage and air back-fill as you did before, and then you would seal it up and then you would ship it to the MRS facility. Once it arrived at an MRS facility you would have to go ineide what is called a transfer facility. The difference between this transfer facility and the one in the fuel pool is that the one at the MRS will be a dry transfer whereas at the reactor you used what is called a wet transfer where you submerge both the storage container and the transportation casks into the pool, but at the MRS facility you would bring the transportation casks in inside a closed 
transfer cell, and with remote operations you would remove the fuel assemblies from the transport container, move it over, and then insert it into the storage technology that is used. Once the storage technology container is filled up, you would seal it up and transport it on site out to the storage area and leave it sitting there until it was to be shipped to the repository. Now when it is shipped to the repository, you basically have to go through the same transfer steps, you have to bring the MRS storage container back into the transfer cell, you have to transfer the spent fuel from the storage container to another transport container and then it would be sent to the repository. Once at the repository it would have to be transferred from that transport container to its waste package that it will ultimately be stored in. So, that is a long winded discussion of all the steps, we can see that there is a lot of handling sequences in that. Now in this new technology that is being looked at or initiated called a universal canister, what you would do is at the reactor you would take the fuel from the fuel pool and store it inside, and you would load up a canister in something like 20-21 assemblies would be inside this canister and you would seal up this canister, and then you would seal it up. ...radiation at the surface, there is regulatory requirements on how much radiation can be present on the surface and then how much from a distance of 2 meters and so forth. All of these technologies--their limits that they are constrained to are the same. They all have to meet with those limits.

As it suits, the limits go lower, I mean the radiation level goes lower. That is true. So, if you have one that is dropped way down and you bring one up that is a little higher in does that make the low one come back up?

No, it would just be like if you had something that had a radiation of 10 units and one at a radiation of 5 , it doesn't mean that the 5 will go up to the 10 , it means that inside that container you would have the average of those two.

So, it doesn't pick radiation from something else.

No, the radiation is internal it is given off internally or the majority of it is given off internally.

So, you measure in radiation though, like you got a gas tank though, you have 20 gallons of gas. Someone asks you how much do you have and you gay 15 gallons. Okay, how much fills one of those old containers?

Each fuel assembly contains about a half a ton of uranium so, What is the level of that uranium? Well, it differs on the age of the fuel. When you talk about the radiation of the fuel, if you look at just bare fuel assembly, and your fuel is something like 5 to 10 years old and has been out of the reactor about 5 to 10 years, your dose rate (the amount of radiation that is given off by that assembly), is somewhere around 4 million units per hour maybe the radiation dose rate that the assembly may be giving off. That would be a lethal dose if it was not inside a shielded container or you know if you do not take shielding precautions. So, if you have 10 year old fuel giving of something like 4 million units of radiation per hour, now the regulatory limits are that outside these containers on the surface, it can be no more than 200 units of radiation per hour. So, the weight, the quantity of the spent 
ruel inside the containers as well as the age of it and how it was used, all goes into how much radiation is in the container.

In negotiations you can set the age of the spent fuel that you take into your MRS, is that not correct.

Yes, right now the standard contract between the federal government between the department of energy is that the fuel has to be at least 5 years old or at least out of the reactor for at least 5 years before the federal government is required to accept it.

In negotiations can't you say $I$ won't take it unless it is 10 jears old?

Certainly, whatever you feel comfortable with could be a part of the negotiations. As we talked yesterday, when the fuel first comes out of the reactor vessel it has the most radiation associated with it, and as it ages the radiation dissipates, but that dissipation is real sharp. It loses $90 \%$ of its radiation and all in the first year or two. Really, the difference between 5 year old fuel and 10 year old fuel from a radiation standpoint is not-there is a difference-but it is not that significant.

So the government has protected them in saying it has to be at least 5 years old.

Yes and also why a major driver for a while why it had to be 5 years old is to design the storage modules and the transportation containers, you have to have some boundary for what your design conditions are. We know what the range of radiation level, what the range is for heat for 5 year old fuel, so we can design the different components of the system for that type of fuel.

In the MRS, how long are they designed to hold it before it is moved to a permanent?

Well, you know the MRS facility would be licensed--you know the storage containers would be licensed for the 40 year life of the MRS facility, so you know. . . but they aren't going to hold it for the full 40 years... well they may not hold it, they may hold some of it, I don't think it will be. . it will go both ways, some fuel will be held at the MRS for the 40 years, some fuel may just pass through the MRS, a lot has to do with the scheduling for. . I thought the MRS was designed for a kind of "lay-over" for the repository.

That is true, and one of the big benefits of the MRS is you are able to consolidate shipments, but that is not to say that some spent fuel that maybe put in storage at the MRS facility may not be moved straight through to the repository after 2-5 years, but then again it may. Also, you couldn't dictate constraints on how long the fuel could stay there once the repository is operational, and so forth in the negotiative agreement.

So there is going to be enough space in an MRS to almost keep it as a repository would.

Well, the MRS has some limits set by law. The MRS up until the repository is operational, ---right now, today there is approximately 20,000 metric tons of uranium that is stored at the reactor sites today, that is 20,000 tons. The MRS by law can not hold or store more than 10,000 metric tons until the repository starts operation. Once the repository starts operating, then the MRS limit increases to 15,000 tons, so 15,000 tons is the most by federal law that a MRS facility can store at one time. Now the 
host can, if the host wanted to, increase that storage limit they could or if they wanted to decrease it, they could. That is all open to negotiations, but there is a finite amount of storage that is allowed to be at the MRS facility.

And they can only be for 40 years.

Yes, well the MRS facility can operate for 40 years, that doesn't mean, you know it is hard to say how long the fuel, if you moved the fuel assembly in, or put a storage container out in the storage area, how long it would actually stay there before it is moved.

How long does the radiation stay on the spent fuel?

Well, basically the repository, right now has to be designed for a 10,000 year life. To isolate the spent fuel from the environment for 10,000 years. Now, what is interesting is and it varies based on how old the fuel is, or how in radiation it was and so forth, but after about 600 years the radiation levels associated with the spent fuel would be something equivalent with the natural radiation levels are when you mine radiation today.

How do they know that?

These are some projections, I mean no one has dealt with spent fuel for 600 vears, but it is a very well understood science and these are the projections based on the dissipation of the radiation levels and so forth that we do know today, that we have measured that around 600 years the radiation level in the spent fuel assemblies would be reduced to its equivalent to the natural radiation in uranium mining.

Looking at it for our kids, or our grandkids, if we take in some of this radiation in these modules, 40 jears down the road this thing is due for the license to run out, it's not us, we're gone it is our kids and grandkids who have to deal with it. What if they have the limit the 15 or whatever, and there is not a repository where they can get rid of it, what is going to happen?

What you have to do, and this is another place where the negotiate agreement comes in, basically there is a lot of things that a host can do to make it such that there would have to be another place to move it to. You could put economic penalties and so forth in the negotiative agreement that would escalate so high that the federal government would have to do something else with the spent fuel instead of leaving it at an MRS facility. It all goes back to the agreement, and how it is set up and so forth, but there are ways to protect yourself in that situation.

When we get into this, the more that you understand it, it seens like the more questions and the deeper involved they get.

That is good, that is what this phase of the program is all about. To encourage a potential or grant applicant to study what an MRS facility is and to study what radiation is and to make an informed decision on whether a facility such as this is something that you would want to host. That is the whole intent of this voluntary negotiate siding process that we are in now is to--it is a fact finding mission and to satisfy yourself that. . Number one is the facility is a safe facility, as you heard today in the meeting, if you can not satisfy yourself that an MRS facility would be a safe facility then you should drop it now. That is a 
paramount question that you have to decide for yourself. Do most people once they have seen these and have been educated and all of this stuff, do they believe what is said, I know you have your radicals that are never going to believe it even if the geiger counter is around their neck and it never noves, but do nost people come around and believe the technology, and look at all of the results and believe them?

Yes, I think they do, you know we could talk about this a lot in meetings and so forth, but until you can go out and see a facility like we will tomorrow, it is hard to visualize what we are talking about, and I think once people actually see the facility and what we are talking about, one of the biggest comments is "is this all there is to it," and seeing the thing live and being able to focus on the thing we have been talking about, once people get more involved and more informed then they are able to make an informed decision, and I think this decision--and it has been documented, a number of these reports that have been developed by these grant applicants in this program. There is neve. a problem, we always feel like it is a safe facility. They really don't have a safety issue with it, it's more of a political issue than a safety issue once you have studied the process.

What about an educational video, kind of like a home video, where people go out and they see it and you are videoing them seeing it, would that be beneficial in educating a tribe, because you can't the tribe to the site, so would that be the next best?

Yes, and that has been done by a number of applicants also. There is a number of tapes out there, and I will try to get some to you that some of the other tribes have made, and some of the other communities have made at these facilities interviewing different people, and that is a beneficial way of getting the message to the community about what is being studied. Also as you say, seeing is believing, and the more people, I know that you can't take everyone on a facility field trip, but the more people you can involve and take to a facility the better off the things are and the more the community learns about the process. Also surrounding communities extend the region of influence and invite others to see the facilities too.

What about the public broadcasting networks on TV, how do you go about getting them to show this kind of stuff?

I'm not sure how you do that. I do know that the department of energy does have some of these closed circuit educational programs that they are able to transmit, and we can check into that and see what it takes to actually get something like this on the air so people could see it in their homes.

A lot of people watch channels like the Discovery channels, and if things could be put on those channels just little short clips and expose people to this stuff; evergbody associates it with the nob or these bad movies that are made about it, the China Syndrome, why can't they put out on some of these educational stations, videos that shows the charts and the drawings like you had yesterday, very elementary, big in size, that would nake people a little more trusting and receptive.

That is a difficult question, $I$. . .but is there a department that even handles the education that we could talk to? 
Yes, there is a couple we have, the department of energy has the office of public affairs and the external relations groups that are involved in this type things, so we can discuss this with them. I am not real familiar with---what you are saying is exactly right and I don't have any specifics on why it's something like that. It hasn't been done, or whether or not it can be done, but $I$ would think it. . .

It seems to me that the U.S. government and the department of energy, or somebody would want to put this on say once week on the discovery channel, just repetition to get people used to it, and just throw it in there once a week, something about nuclear naterials, the safety of them maybe. These facilities are going to come around, just some elementary general information that would kind of take some of the scare out of it. It seems that the government would want to do that to me.

That is a good point and we will surely have some more meetings with the department of energy and all and we can maybe contact some of these groups.

It will be no problem to get permission from the DOE to put on a sall ainiproduction would it?

No, basically with the grant funding and so forth that is your money and however you see fit to use it in this educational phase is up to you.

Because I have a plan for a miniproduction, and I wanted to go with a more diversified movie production, and include this MRS project. I have all the personnel together, the script and concept, and the technical personnel, after I see this facility over here, what do you think if you look at a facility like this and you build your own facility out of cardboard box just for movie purposes, do you think a facility like this would object to us using their style?

No, I don't think they would, are you talking about the storage style, and everything, and also there are models available that we could--something similar to the stuff that you saw today that have already been put together that we could loan to you or give to you based on if we have any more process. .

It would be nice if we could get your help, if we were going to make a production, but I have an interesting concept. • •

The little rods, do they all have the little springs in them? and how big are they, and what about the rods?

As you saw today, nuclear fuel is in the pellet form and the pellet is approximately $1 / 2$ inch in length and maybe the size of a pencil eraser is what they look like. Then you take these ceramic pellets of uranium and stack them end on end in these metal rods that are approximately 12 feet long. It takes about 200 pellets per rod, and then there will be some gap at the end of the rod itself where you put the springs to make sure that the pellets stay confined within those fuel rods. So, the fuel is always solid in form. The ceramic pellets never change form even when they are in the reactor undergoing and being subjected to the 600 degree temperatures at sometime approaches in the reactor vessel. These pellets stay in the ceramic form and do not turn to liquid. As they go in there is a physical form that they will stay during the 
whole life of the fuel assembly.

How does it work? You put the pellets in the rod and put the springs on each end but then what do you do with the rod?

As you saw today you take those individual rods and you bundle them together to form a fuel assembly. There is about 200 rods, 200 pellets in a rod and 200 rods in an assembly. These are all bundled together and the assembly is of course 12 feet long and it is about 12 inches square in cross sections.

So that was an actual assembly sitting on the table.

Yes, it was a cut-away, it was the actual size it just wasn't the full 12 feet long.

In the assembly, there are great big springs on the ends of

it?

No, that is just how the assembly is measured on the inside of the reactor vessel. That is just how they are supported inside the reactor vessel. What happens is once you take these individual assemblies and load them inside the reactor vessel and the number 200 comes up again because there is about 200 of these assemblies that will be in the reactor vessel at any one time. Now once you put these assemblies inside the reactor vessel there are what are called control rods which is lowered down into the assembly when it goes in. That sort of absorbs the neutrons so the fusion process can not start. The fusion process is when the neutrons start flying off of the--you are splitting the neutrons, it is like a friction type thing, and when it hits it the friction causes heat and that is what heats up the water and so forth. When the conditions are such that you remove the control rods and you have water around the fuel assemblies and the fuel to act as a moderator then you have this chain reaction occurring which causes the neutrons to be sent off, and friction causes it to heat up. there.

You were saying that they put a rod that activates it down

They have what is called a control rod, it is in the assembly they have control rods, there are multiple control rods, and when they are inserted into the assembly and the fuel assembly is in the reactor vessel, then they absorb some of the neutrons that have been split off. When those rods are removed, that allows the neutron collisions to continue, and reash what is called critical mass, where you have a self-sustaining chain reaction, and that is when you have the bombardment of the different neutrons and so forth that produces heat. Then, the way you shut down a reactor is that you insert those control rods back into the fuel assemblies and then that absorbs the neutrons and it reduces the collisions and cools down.

But it does kind of hum in there with all of the vibration.

There is really not that much vibration in the reactor vessel itself. It is just particles colliding with one another, the humming you hear is from around the plant really has a lot to do with the steam lines and the turbines and so forth, but it is not with the fusion that is going on inside the reactor.

The uranium is what makes the radiation or what?

New fuel assemblies when you put them in, before they are put into the reactor is not that radioactive. You and I could walk up and touch one of them. If you go through the Westinghouse Fuel 
Fabrication plant where they are making--you know there is no special precautions the workers have to have to handle with them, now once you put them in the reactor and start this fusion process, it changes the makeup of the fuel itself and during this change it creates radioactive isotopes and so forth during the fusion process, splitting of atoms and so forth, and this by-product of this fusion process is actually what is radioactive. That is what stays with--causes the radioactivity of the spent fuel for years to come.

It kills cells, isn't that what it does?

Radiation, if you had fuel exposed to a certain level of radiation it can kill them.

And that's what kills you and always will.

It is just like with radiation therapy on cancer patients. You give them the therapy and you may lose some hair or become sick, that is killing of the cells, but you know there is a threshold for if you receive up to a certain amount of radiation you know that it has no real impact on the cells or on the persons health. It is just that these high doses of high levels of radiation that you have this impact and like I said before, everybody is exposed to radiation on a daily basis and it is just the level of radiation that you are exposed to.

So, that little rod is the actual little rod there is just 80 many of them and just so many of them put together is what makes all that, you would not think anything that little would produce that much.

That little simulated fuel pellet that you held today, that produces an equivalent amount of energy equal to one time of coal. The heat produced from that little pellet has an equivalent heat value of one ton of coal.

One of those units, one of the 200 rods put together and then the 200 put together in the thing, how long does one of those last?

You remove about a third of those 200 fuel assemblies about every 18 months. So, once you put a new fuel assembly in a reactor, it will stay in there approximately 3 years before you will remove it. boost.

It will last about 3 years, but every 18 months it gets a new

Yes, and what you try to do is move the fuel or balance the energy across the reactor the new fuel you put on the outside, further away from the center reactor and then the older fuel you move toward the center. So, what you are trying to do is balance the energy profile across the reactor.

Is the reactor what absorbs what is going on inside and takes it on out? Is that what the reactor is?

The reactor is a big vessel with thick walled steel vessel, and it houses the fuel assemblies and the primary cooling that circulates around it. It does absorb some of the radiation given off by the fusion reaction.

It will actually take the as in the storage, it will be like rotating batteries.

Yes, every 18 months each reactor will shut down for what is called refueling. During this process it will take out aproximately one third of the fuel assemblies that is in the 
reactor, move them to the spent fuel pool and then put a third new fuel assemblies in.

Is there always 200 of those in a. .

It varies based on the design of the reactor, so there are two or three different reactor suppliers/vendors that have designed these. The 200 is within plus or minus $10 \%$ of all of them.

The one we are going to see tomorrow, it is the liquid, and the water?

Yes, the type we will see tomorrow is the liquid, there are two types of reactors: one is the pressurized water reactor (PWR), that is the one that we will see tomorrow, it is basically--you keep the primary coolant under pressure so that it doesn't boil that is around the fuel assemblies; the other type of reactor is called a boiling water reactor (BWR),

We aren't talking about storage we are talking about reactors.

We are talking about reactors. There is nothing like this, there is no liquids, no boiling, no critical mass, no chain reaction, nothing like that in storage. This is only in reactors, the boiling water reactors actually boils the water that is around the fuel assemblies, whereas the PWR keeps that water under pressure so that it doesn't boil. That is the difference in the two, and the fuel assemblies are different. Most of the reactors in this country are PWR, there is only a small percentage that is BWR.

Why the boiling water, just because of the heat that is coning off? It really doesn't serve a purpose?

It is just the way the reactor was designed. I am not sure of the concept behind it, but instead of keeping the water under pressure, see in a boiling water reactor you don't have two loops that circulate in water. Ycu have the primary loop that is circulating around the fuel assemblies themselves and it is boiling and then you have the cooling water circulating around that boiling water to cool it back off. Now in a pressurized water reactor you have three units/loops of water: the primary loop-real hot, 600 degrees, but it is kept under pressure and is prevented from boiling, then it goes to the steam generator and is passed to what is called the secondary loop-where heat is transferred from the primary loop to the secondary loop, and the secondary loop is allowed to boil and form steam,

None of that is ever released.

No, it is all contained. Around these reactors we will not go inside the containment building and the reactor vessel is housed itself inside a building called the containment building. It is a large structure walls 3 foot thickness, and it is air tight, it is sealed up and when the reactor is operating, you really can't go inside the containment building. Inside the containment biilding it is designed to contain any worst case accident scenario of radiation, that is the engineers safeguard around the reactor to insure that if an accident did occur that if an accident did occur, then the radiation and so forth could be isolated inside that containment building and not harmed the environment or the general public or the workers. All this--the MRS is totally different from this system, it is a totally passive system, there is no pressurized systems there is no boiling water it is a very passive 
gystem.

Didn't you have cultures on the water yesterday? And can we get pictures of that?

The different loops in the water. We sure did, and I can get you pictures of that. It is hard to explain all of these loops without the pictures. Maybe we have something in the folders, and maybe we have a black and white picture or something, or I can draw you a little diagram and help. We can get you some of those pictures.

The thing we haven't discussed a lot is the MRS facility and what would gc with it. Like I said the purpose of the MRS and the functions of the MRS facility are to receive spent fuel, to transfer spent fuel to a storage mode, to store spent fuel, and to transfer spent fuel back to transportation mode to be taken to the repository. In do:ing all of this there are some other facilities that could be and are planning on being co-located with the MRS facility. One of these are calling the cask maintenance facility. This is where after you make a shipment with a transportation cask, these casks will have to go through these casks maintenance facilities periodically once a year, or whatever the requirements are for inspections and so forth, so this is a facility where you would actually be doing some inspection type work, and all on the transportation carks, and any type of small repairs that are necessary. In addition to all of this, you have to develop a communications system. One of the requirements that we are operating under, is that you must maintain contact and know where all of these shipments and so forth are at all times. So, there is some satellice communications systems and communication systems that will be constructed in order to track these shipments as they are coming to tne MRS facility. Then there could always be a spin off type of businesses, there could be nuclear training facilities, and so forth bill, that could train the workers for the MRS facilities as well as other nuclear type of worker. There is potential for a lot of different types of spin off industry, buth nuclear related and some that aren't, that may come along with a MRS facility. MRS facility is divisioned to take the construction workforce for the MRS facility, $:$ is divisioned to be somewhere between 1000 to 1200 to 1500 people peak, it will probably average at 700 people, and we are probably looking at an overall construction period of around 3 years. Right now with the current operation modes and storage modes that are being contemplated, the operating staff for the MRS facility will range between 450 to 500 people. All of these are preliminary numbers based on conceptual design as we see the MRS faciiity now. Once the repository becomes operating, the workforce may go up more at the MRS facility because not only will we be receiving and storing fuel we will also be shipping fuel to the repository. That 500 employees may 80 up to 700. In the business ofportunities study that we gave you today, it identifies the type jibs that we anticipate being available at the MRS facility, and breaks them down between management, technical staff, clerical, the whole gauntlet of jobs. We anticipate at least $80 \%$ of these jobs to be filled from local workforce. There are some $20 \%$ jobs that may require specialized degrees, but the $80 \%$ percent of the jobs could be filled by local 
workforce. This is a hightech. type job, this isn't something somebody could basically walk in of It would require some training, and some specialized training, and all of this could be set up such that you could develop these training facilities prior to the operation of the MRS facility and then once MRS comes operational the workers would be trained to 80 to work. This can be set up through the negotiating agreement, and you could have stipulations about when and what type of training will be available to your community that ultimately hosts the MRS facility. These jobs would make it so that an individual could work at a number of different type jobs and wouldn't be limited to an MRS type facility if he took the training. He would be well suited for other type industries and so forth.

Does the facility we are going to see, what is the name of that again?

It is the surry nuclear station. It is one of the nuclear stations that Virginia power and operates. I am not real sure of the--I think the facility came on-line in the early 1970's, and it is a two unit reactor. I am sure they will give us a lot more specifics on the plant itself tomorrow.

Do you think it is possible that we could get a policy and procedure regarding the employees of the plant?

As far as the operating procedure?

Like when you get hired, it has a policy and procedure, termination, unemployment.

We can ask. I am not sure what their policies are. I do know some of the policies that we do have at some of our nuclear stations which we will see tomorrow.

How much do they get paid an hour?

It varies on the job, but I'd say an average of between--this is the mid-level jobs and they don't require any specialized degrees or anything--probably between 12-16 dollars an hour range. Our Okonee nuclear station has three units, and I think we employ somewhere around 2,000 people at that plant. The MRS isn't that big of a facility and wouldn't require that big of an operating staff, about 500 people or so is what we are looking at for the MRS. I think that the business opportunity study has some salary arrangements also which goes along with these different classifications of jobs. You will have everything from technicians to security to managers to clerical, just the whole gamey. It is all spelled out.

The job descriptions.

Yes, in the titles and so forth are such that you can understand what the jobs are.

We reed a break down and they basically work 40 hours per week, or is it a. .

What we envision is initially, until the repository starts operating, the workforce, it would be 40 hours a week, at probably two shifts a day 5 days a week. Once the repository comes on-line we start shipping fuel to the repository, then I think that the workforce will increase and we will add another shift and start working 24 hours, three shifts per day, and maybe seven days per week. There is a lot of what if's in there now, and a lot will be based on the final design of the facility, but conceptually there 
is a possibility to going three shifts a day, around the clock operation, but that would be on down the road if that occurred.

Do they anticipate a decrease or only an increase of their enployees?

There is some limits as far as, a moment ago I talked about the limits for the amount of fuel to be stored at the MRS, there is also limits on the amount of fuel that can be incoming to the MRS. The first year of operation, there is going to be 400 metric tons of spent fuel that will be coming to the MRS, the second year there will be 600 , and the third year there will be 900 , and it will stay at that level up until the repository is operational, once the repository becomes operational the MRS can handle/transfer up to 3,000 metric tons per year. That is a combination of incoming and then shipping to the repository, it is both. There is no vision of a decrease staff, it is always an increase staff to handle that additional activity at the MRS.

About the only way it could decrease is to quit using electricity.

That, but there is 20,000 metric tons of spent fuel that is stored at the reactors. The total quantity at the MRS is limited to 15,000 so even if we could move all of the fuel at one time to the MRS, there would still be 5,000 tons spread out among the reactors, plus we would still be producing more each day. Basically, reactors produce approximately 30 tons of spent fuel annually, one average size ieactor will produce about 30 tons per year.

A reactor could close down.

It could, and somehow--now the criteria of who get to ship-one of the issues we are addressing is who gets to ship to the MRS when, which reactors get to ship their fuel from the reactor to the MRS and the time and the quantity, and the way it has been set up now is what is called the oldest fuel first process. Where as the reactors that have the oldest fuel in their spent fuel pools are the ones who get to ship first. If you had a reactor that came online in 1970 it would be able to ship spent fuel to the MRS before a reactor that came on-line in 1980 .

Do they have to pay to send it to the MRS?

The MRS is funded by the utilities. Any utility that owns an operating nuclear plant pays a sur-charge a tax on the operation of that plant. The utilities pay into what is called the Nuclear Waste Fund, and this is the money that has been accumulated over the last since 1982 is when it started, this money has been accumulated and this money is to be the funding to build and to operate the MRS and to develop the transportation system as well to develop the repository. Utilities have already paid into it, that is the money that is being used to iund these activitics, and there is no taxpayer money that is involved in this.

They aren't going to sit on it and keep it in their pool because they don't have the money to send it, it is already paid for, through the sur-charge.

They will not have to pay additional fees to ship the spent

fuel to the MRS, it is already paid for.

Who pays the sur-charge?

Right now the sur-charge is part of the rate base that the 
individual utilities have that is controlled by the public utilities commissions in the state. This charge is passed on to the customers. I think 
FORT ST. VRAIN NUCLEAR STATION

INTRODUCTION BY STEVEN S. SHERROW, RADIOACTIVE

WASTE PROGRAMS COORDINATOR

- We arrived at the facilities

I got my training in Nuclear Power Technology so to speak from the United States Navy. I spent six years on a guided missile cruiser that had two water cooled reactors on it. I was primarily trained as a radiation protection and chemistry technician. When I got done with that I was fortunate enough in order to come back to my home town and get a job at the local nuclear power plant and I started as a health physics technician providing for radiation safety at a job site. Actually covering maintenance guys out in the field and making sure that they were doing their work safely. From there they created a new position to oversee the radioactive waste processing and packaging and transportation issues so I took that position on a professional level and pretty well managed all of the radioactive waste issues that we had here for about two or three years. And, then we started looking at what is the future of Fort st. Grain and they created a team to begin looking at decommissioning options knowing that decommissioning was going to be coming up in the future not knowing how soon that was going to be. This was in 1988 and I was assigned to that team while I was also doing some of my radioactive waste things. At the same time they had another team that was looking at what it would take to refuel the reactor and continue operations. So we had two groups going in opposite directions here and it was a little tough getting some resources sometimes in order to do some of the little work that needed to be done along the way. Unfortunately the decommissioning people won out and that's a long story and probably not really related to what you came to see here, but to make a long story short, Fort st. Grain is a gas cooled reactor and this is different from any other reactor in the United states. Primarily, reactors are either pressurized water reactors or boiling water reactors in the United states. Their fuel is a uranium highly enriched fuel after its been processed and refined it is encased in rods made of metal. These metal rods then are put together in bundles usually square. These fuel bundies then are installed inside of the reactor and as the uranium fissions it creates heat and the heat is transferred to water which is then transferred to the steam generator that makes steam. Here our fuel is again uranium but its highly enriched its in the range of $94 \%$ or $96 \%$ enrichment, I can't remember anymore. But compared to the 8 or 10 or $12 \%$ enrichment that other plants use in the United states ours is highly enriched uranium. It's not bond grade, but it is highly enriched uranium. Our fuel also contains a certain amount of thorium --the thorium will absorb a neutron and go through a decay process that creates a uranium $232 \mathrm{I}$ believe it is which is a fissionable material. So we're not a breeder reactor we're a converter reactor where a certain amount of our fuel is actually generated within the reactor and then used in the fuel cycle. The fuel is contained in discreet kernels. And, by that I mean that the particle is about the size of a period on a printed page. Then 
it is surrounded by a variety of ceramic coatings that hold the fission products within that fuel kernel and then these are mixed with a glue of sorts and are made into small cylinders about the size of your little finger. These cylinders then are put into graphite blocks with little passages in them and these graphite blocks then are about the size of a 30 gallon drum or our fuel drums. So instead of having metal bundles of fuel rods that stand at least 8 to 10 feet tall, I'm not sure. We have a graphite block about 32 inches tall and about 16 inches in diameter. So that is some of the differences about our fuel that kind of go into some of the reasons why we made the independent spent fuel storage installation and chose this particular design technology over other design technologies that are out there. So as we go through our discussions today that is kind of the description of our power plant that as we go through some of the discussion of why we chose this technology enter in to those decision making processes. Anyway to continue about my background, I was chosen to be on a team to get the decommissioning process planned and Implemented on the front end and that work is completed and now I am working for the radiation protection manager here overseeing the decommissioning implementation from a radiation protection point of view primarily. But then another big portion of my job is I oversee the security arrangements at the onsite storage facility. Marty Block, the gentlemen who you were all anticipating in seeing this morning, his father is undergoing some medical evaluation this morning and he needed to go to Denver in order to do that. So I am sure that you will join me in wishing Marty's Dad the best of luck in coming through that. And, we look forward to the good news that comes out of that. But in the meantime, I am going to do my best to substitute as your host this morning. What I am going to do is show you a video tape, and the tape that I am familiar with is one that was produced by Public service Company of Colorado, this particular one was given to me by the contractor that was responsible for the design and building of the Independent spent Fuel storage Installation and I haven't actually seen this before so I am hoping that it doesn't have dancing girls on it, but if it does....

Can I ask you a question?

Sure.

How long have you been around this in years? Nuclear Material?

Counting the ten years that I've been with the Public service Company another four years in the Navy and two years on top of that spent in special schools that were conducted by the Navy so sixteen years total at this point in time. But actually working in the field for fourteen years.

Where was the fourteen years? Because if they see you they are going to say wait a minute cause you ain't got no hair. 
it.

No, this is genetic. This has absolutely nothing to do with

That would kind of be difficult to explain that but,

No, it was kind of funny. I was taking highschool biology many years ago and we started talking about genetics, and I was the example of male pattern baldness that genetic issue that comes up in certain people. I had to stand up in class and the instructor came by and said see the widow's peak, see the receding hairline. It was pretty embarrassing so it stuck out in my mind. But, by the time I was 21 and entering the Navy before I had any occupational exposure to radiation, I looked pretty much the way I do now, except I had a moustache then. But, uh...

Where did you go to school at?

Well, I'm a native of Colorado. I grew up in Greeley, which is just North of here about a half hour. I've spent some time at the University of Utah and a little bit of time at the University of Colorado, and I came to a crossroad in my life where I was wondering whether I was really cut out for college life or whether I was just there to party, so I finally decided that I was there for the party, so I joined the Navy and what they do is they put me in school for two years where if I didn't make the grades they took away my liberty and said you're gonna stay here and study doggoneit and you're gonna make the grades. So, it was kind of a.. I didn't really achieve what I wanted to there at least on an initial step. But, it is a situation where Nuclear. Power has been very very good to me and I think I've got maybe not as deep an engineering background as other people we have out here, but I think I've been given enough training over the years and had enough experience over the years to know that what we are doing here has a very adequate marginal safety that what we are doing here is ... you know you can get arguments about it... but really in the public interest. I have a lot of confidence in Nuclear Power as an energy source. You won't find me on a petition to shut down any Nuclear Power plants around the country. I really feel good about this technology and hope to be able to transmit some of that good feeling to you and your efforts to evaluate this as a potential for your communities back home. And, also as an economic opportunity because there are people out there that are willing to pay big bucks in order to have the problem go from their backyard to somebody else's. From my way of thinking, it is a pretty good opportunity. A very good economic opportunity for a very low risk.

Can you describe the economic impact that this plant has had on this community...this area?

Well, just to not in depth, but to kind of give you an idea. About three years ago, we had close to 600 people working at this particular plant. We were the major tax payor for the school system, the taxing district for the school district is, Hillcrest which is.. I don't know did you come up Interstate 25? 
Yes.

okay, well you didn't go through platteville then. Plattevilie is the community to the southeast of here about 5 miles, Hillcrest is up the road and this plant provides the tax base for that school district to platteville and Hillcrest. About three years ago when we were talking about decommissioning, they put off building a new highschool because of the unreliability of this facility as a tax base. We're working on converting this plant to a fossil fuel plant and now the school district is looking at it once again in doing their expansion that they need to do.

Who owns the property here?

The Public Service Company of Colorado. As you came up, you went by the turkey farm on the north south road. When you made the turn from the turkey farm road just before you made the turn that came by the plant, that's County Road 34. We own the property beginning there and it stretches from the st. Grain creek on the west to the south Platte river on the east and it goes to the of those two waterways. It's in the range of 22 hundred acres and we own the land, the water rights, and oil rights. What we do then is we control what activities occur on this land so that we have control over the impact of safety to the power plant and when I say that I also include the ISPC also. For instance, whenever gas or oil drilling activities were being conducted here, we have to consider those activities in the total safety aspect of the activities that go on here. We have to write a justification to the Nuclear Regulatory Commission of that activity is (1) not an unanalyzed activity. It's one that has been looked at before and found to be safe. And, (2) that it won't decrease the margin of safety that's already been established for a baseline drop rating on our plant in performing our activities here. The other thing is that it gets us in a situation where we kind of control how many people live within the very close proximity of the plant and how close they actually reside. Now, this becomes important in emergency response, so it is not a day to day health issue. It's an issue of how many people we have to deal with from an emergency response point of view and how many people we have to get on the phone and say, "Hey we had an unusual occurrence here and until we know more about it, you probably ought to stay in your house." You know that is an extreme situation. You know that kind of phone call is in our emergency procedures for instance we've never had to do that. I think the only time that our procedures required us to call the neighbors outside of Grillson area which was in 79, I believe it was, we had an unplanned release of radioactive gas and the notifications were made, but in looking at the incident in retrospect after we were picking up the pieces so to speak, we found that we overclassified the event, and we didn't really have a situation that would have gotten us into a notification of that magnitude.

But, was it your responsibility to overclassify it for safety? 
Well, what we train people on is if you are going to air, air in the conservative direction. So instead of saying that it was, you know there used to be four general emergency classes. You had a general emergency which is a Chernoble type of thing, you had a site area emergency that might as a precaution include the evacuation of non-essential personnel. You have an alert which you initiate il of your emergency stations and your emergency organizations so that you can manage the incident in an organized and planned fashion. And, you have a notification of an unusual event, which is important kind of thing. Then below that you also have incidents that might occur, you know a piece of equipment that fails without notice or something that requires notification or overseeing but not any accident within the organization. In this particular case what they did was they declared an alert or either site area emergency when it fact it should have been a notification of an unusual event, which when we went back and looked at it some more. I'm sorry you wanted to get on with it. Should we ask questions later?

Well, why don't we go ahead and finish up this particular one. You were going to ask a question.

In terms of the gas release of course we are aware that people are using experimental technology here. Is the experimental element the gas cooling?

No, we use helium gas as a coolant, rather than water.

Okay.

And, what happened in that particular, that was before I joined the company, and the details are a little sketchy, but they had an unplanned release of this gas. And, I believe what happened is they had a relief valve on a tank fail and then that tank vented to the atmosphere and you know it was unusual, it was not planned, it was outside the scope of normal operations, so it got us into the emergency response classifications and emergency procedures. But, in going back and looking at it the only thing that was unusual about it was that the tank got overpressurized in the first place, and the relief valve lifted. So the amount of radioactivity and the Dorsch rates to the general public and the residual dose from that radioactive material release were really minor and if they would have taken the extra time in order to evaluate what they were dealing with, they would have come up with the correct classification. But, in their urgency to get the organization going, they looked at it and saw that it fit a general classification for an alert category, so they declared an alert. Then once we got into it they said let's look at the initiating event once again and make sure that we classified it correctly. They wanted to make sure that it shouldn't have been a site area emergency, for instance. But, when they did that they found out that it should have been a notification of an unusual event, a new event which wouldn't have required manning of the emergency stations. 
What was the response to the error?

I really don't know, again, that was before my time, and a long time ago. So, I don't know what kind of specific response that the neighbors had. You know the state was notified and they did some monitoring of the environment around the area. We did some monitoring on our own in order to document what actually occurred. whether the area neighbors were notified or not, I couldn't tell you on that. But, if you like I can try to find that answer for you.

would you?

Yes.

Because of what the situation is we'd like to know the reaction of these to the response.

I guess the thing to come to a conclusion here is that what you need to do if you are to proceed with this project is make sure that you have an aggressive public information program where the people in we'll call it the affected area and you're going to have to define how big that is. The people that are living around the proposed site or potential sites get trained in what is being done. Get out the information necessary for them to be comfortable with the decisions that you folks are going to be making. So, that they can be in a support role rather than in an adversary role. And, you know in the case of a dry store facility, a monitored retrievable storage facility of some kind, the types of accidents that you can have from that, and I'm not as expert in that as you are going to be able to find other people, but you can have I think on the worst case of transportation type accident bringing the material to the storage site. And, that really is probably going to be the type of thing that will give you the best video for television. Because there is going to be wrecked vehicles, possibly fire, which there is going to be lots of response organizations, where once the fuel is loaded into a storage canister it is in a state of storage. It is just resting there. You are probably going to pick a technology that doesn't require you moving parts, or pumps, or filters, or fans it just sets there and actual convection cooling is going on and it just, there is nothing to fail, it is very passive operation.

Even if the electricity were to be cut off completely?

Nothing fails as a result. So your lights might go down and you might have a security issue that you need to deal with as a potential response, but the safety of the fuel itself is guaranteed because it is a passive operation. So, the accident scenarios that you are probably going to be looking at in that case is what happens if a seal on one of the canisters were to fail. Well, in our case, we looked at that and we saw what would get the radioactive material out of the canisters and into the environment, the canisters aren't pressurized there is nothing there in order to 
drive the radioactive materials through this failed seal so in this particular instance you have nothing in order to cause a release of radioactive material into the environment. So, we took a look at that and said, well let's dream up some worst case scenarios and say there was a little bit of pressure in the canister and was a lot of activity drifting around in that canister and some of that got driven out. What would be the result? And, we came up with just a few milogram, I'm talking in the range of 1 or 5 or 10 milogram total exposure to the immediate surrounding area. Because once it gets out of your facility it is diluted into the atmosphere and probably fall out in the general area which is going to be within your defined control area where nobody is going to be living or growing gardens or herding sheep or whatever the case might be. You aren't going to have any activities going on there where people are really going to be impacted as a result of one of these things. you could have a fire, you could have a flood, you could have a tornado, you could have, I could just keep going down the actual disasters and those type of things, you just need to design your facility in order to take into account the type of atmospheric events that might occur in your general location. And, make sure that when you design the facility that you make it not only the normal but the predicted and some margin of safety above that. In our case we designed the ISPC for I believe a 200 mile an hour tornado. A tornado with swirling winds going 200 miles an hour. The history here is that 130 mile an hour tornado is the worst that we have seen. Typically, we see 90 mile an hour tornadoes. You know that's the kind of concept I'm talking about here. In the case of a flood, we are well above the hundred year flood plain. But, on top of that it is kind of a plateau area. And, if you look at the two river basins in your mind you can imagine how much water it would take in order to create a flood. And, the only thing that we can come up with in a flood is if one of our storage ponds that is used for storing fire water for emergencies in case all the wells went dry and we couldn't run the pumps to pump water out of the rivers, we've got these storage basins for fire water. If one of those were to rupture and the water flow uphill, what would the effect of the ISPC be? Well, we would get a couple of inches of water around the outside of the building, but it wouldn't get inside. So it is those kind of things that you need to go through as you evaluate the design of your facility and what type of accidents in your area are possible and what kind of accidents in your area should be projected and make sure that you not only evaluate those and have answers for them but also communicate them to people that are in the general area and the affected population, and again you are going to have to define that, but be aggressive in making sure that the people understand what's being done and allow them the opportunity to have input and a sense of ownership which breeds confidence.

What's the size, how big is the affected area? Because if both sides are 500 acres...

I think we took credit for an effective area of our company control property of 2200 acres, but in reality its of the outer 
walls. That's the controlled area boundaries. We control all activities within 100 meter radius.

That's about the size of a football field.

Yeah, about the length of a football field. When we go out to the ISPC you'll be able to see that fence. It is a barbwire fence and it just keeps the tumbleweeds out is about all it does.

If you are in the controlled area, then why hassle with your neighbors?

Well, because it is important to keep them informed. You know it is there, as a corporate citizen in this general area we feel an obligation to answer their questions and let them know that we feel as if we have control over what we are doing, we are not out there running a muck so to speak and provide them an opportunity in order to question in what we are doing and why we are doing it and what kind of provisions for their safety we are designing into it and allow them an opportunity to say, "we're not really comfortable in this particular area, could you explain that to us a little more," or have them come back and say, "this is really bothering us could you design something in order to alleviate this concern?" In our particular case, just the concept of storage spent fuel here for extended period of time was an issue. Once we explained to the population that it was a project necessary in order to decommission the Fort st. Grain reactor and what we were trying to achieve was a larger margin of safety. If we left the fuel inside the reactor vessel itself it's in a configuration there are scenarios where it could go critical. In order to protect against that, there are certain systems that we had to have available in order to prevent that from occurring. So, then the other thing is in order to protect from the result of an unplanned evolution, you had to have ventilation, you had to have fans, you had to have a certain amount of containment, you had to actualiy active systems if the power were to fail, these systems would go down and we would have to start emergency response in order to prevent possibly one of those worst case scenarios occurring or the amount of radioactivity that could be released into the environment. So what we have demonstrated to the general public in this area is that by moving the fuel from the reactor vessel and putting it in the ISPC, you are doing two things. We are putting it in a configuration that it could not go critical, it could not have a self-stating nuclear reaction occur because the material is spread apart and there is enough separation and there is a lack of moderator. Moderator is a thing that slows down neutrons to a slower speed where they can actualiy interact with a uranium atom and cause it to split. By putting it into a safer configuration, it took care of the need to have active systems and it also alleviated some of the concerns of a terrorist action. So, by explaining that to the general public, we were able to resolve some of that concern. In reality, that was there biggest concern that we had expressed. There were other questions that were brought out, but they were things that we had already anticipated in our planning that the NRC was going to be 
asking us those same kinds of questions or the state of Colorado was going to be asking the same kinds of questions. We knew we were going to have to design answers to it or design around some of these things. So we were well prepared in order to answer those things. It wasn't anything new that I'm aware of that the public brought up that we hadn't anticipated. But, it was the selling that we were able to do.

In your contained area, now your neighbors, how big an area did you have to saturate to get their confidence?

Well, we were a little more aggressive than what we probably needed to be. In addition to the local communities, Platteville which is about 5 miles from here, Johnstown and Milican which is $10 \mathrm{miles}$ to the north, the county officials themselves, the county commissioners and we also did a presentation to Loveland which is almost a half hour from here and I think we did at least one presentation at Greeley which is the largest metropolitan area from here. We did go south to Fort Iufton which is the next town south from platteville.

so, about a 50 mile radius?

Let me sketch on this. Okay we're roughly right here. So, we went on at least one occasion as far as Loveland over here to Greeley and we at least included them on our initial conversations, but we concentrated in this general area right here. We did go down to lufton but didn't get out as far as Hudson. It's probably about 25 miles roughly.

But two things that come through loud and clear for me and one is an aggressive public information campaign and bending over backwards to work with your neighbors, state officials, government officials, and involving them in the planning and ....

What we did in this communications effort here with the effective communities was we arranged time with the town councils, the city councils, in the case of well county, the larger jurisdiction here. we were on their agenda for describing what we were doing and allowing them the opportunity to question us. We also advertised that we had people available to talk to civic groups the rotary clubs, church groups, that kind of thing, but then we also have within a 5 mile radius, we have a routine communication with all the population within a 5 mile radius, which does include the entire city of platteville, and we put out a quarterly letter. We call it the Fort st. Grain neighbors and we just kind of go over issues that have come up in the past quarter and the issues that we anticipate in the near future and kind of give a summary of that and just kind of bring them up to date on activities so that, and also include in there on occasion a survey response card and along with that a statement that you can check to say please send me more information or please have somebody call me now that was not all the time, but it was included in those newsletters on occasion. We always had a point of contact in there that if somebody had a 
specific question they wanted an answer to they could call them. Our vice-president as he went around and did these public meetings, he always advertised what his phone number was, his office phone number, if someone wanted to call him directly. He made himself available and so we have in these public meetings we generally had the vice-president who kind of introduced the whole thing, we had a public affairs person who actually gave the presentation and kind of orchestrate the overall presentation, and what the public affairs person would do is say, "this is kind of a general concept and to explain this part of it a little more, here is the engineer in charge of it", and that engineer would come up and talk about his part of the project. And, then the public relations person would get into another area, and you'd have a radiation exposure or radiation protection person to get up and say this is my part of it and depending on the focus of the public involvement meeting and these things are going on guarterly at the beginning and then they went to semi-annual and now they're down to annual at this point in time, because we're getting the message from the public that "we've heard all that and we're not interested anymore", it's not our problem.

When you were describing the model that you had discussed regarding the worst case scenario of the potential seal leak that was supposed to have happened in this model, you described the leak as being 4 to 5 milograms, can you compare that in terms of effect, $x-$ rays, or what have you?

First of all let me qualify my statement. When I was talking exposure, I was talking off the top of my head and I don't mean to say that the written documentation it says 5 milograms, what I was trying to emphasize is that it was a very small effective dose, and I would assume that when I say things like that I want you to assume that it's a total dose from an event occurring. so, over the long term whatever that might be, whether its weeks or months or years, the total accumulated dose from an event occurring would be a very small amount of radiation exposure in the range of about 5 milograms as an example. Certainly not anything where you would start to see health effects. To give you an idea, here in this general area, the actual background radiation exposure for an annual period of time is between 150 and $200 \mathrm{milogram}$. Well, in this particular area its a lot from radium deposits that are in the soil that naturally occur. This area has got a lot of granite formations and if you go to New York City, the most radioactive there is Grand Central station, because they made it out of granite. And, the granite has a lot of minerals in it that contain radioactive materials, uranium isotopes of different kinds. So, in this particular area we are talking about a general background area of dose radium in the range of 150-200 milograms per year. On the average nationwide they say individuals will get another 200 milograms from everyday sources of radiation that aren't natural. Things like smoke detectors, things like coleman lanterns, things like medical $x$-rays for your teeth for some diagnostic procedure that your doctor might do for a test and of course those people that receive a chest $x$-ray or lower g.i. examination, their 
exposure is going to be a lot more than 200 milograms a year, but when you average all of that exposure over the population of the Uniter states it ends being an average of about 200 milisgrams per year.

Actually, the thing is so low, it could be ignored almust.

You can measure it, but it is insignificant. Now, let me balance it against the effect of radiation overall. Before you see any effect of radiation, you've got to get in the range of 25,000 milcigram in order to see minor blood changes. Your chemistry in you's blood will change as you get more radiation exposure. It won't create radiation sickness like you see in the movies about this bombing of Hiroshima but y'vu can start to measure in a healthy incividual chemistry changes in the blood. At about twice that l evel you can start to see physical effects, a person that might be an older person or somebody whose physical nature just isn't as strong as a teenage football player, there you might be able to see the onset of radiation sickr.ess, which may include some flu-like symptoms, you're tired, you might have an upset stomach, you could vomit, you're talking again orders of magnitude greater radiation exposure than what we are talking about from a maximum incredible accident from a failure of a system in a facility such as this. So, that's probably about as much as I need to get into there, but of course every facility is going to have a little different estimated radiation cxposure as a result of its operation. That's going to be dependent on how much shielding you design into it in the walls of your canisters, in the walls of your building, if you have such ': thing. I think you've been to the surrey plant haven't you and saw the big nodular steel vaults or canisters, the amount of shielding you have on that is going to dictate how much radiation exposure you have a distance from that. How old the fuel is you put in there, how much fuel you put in there. There are a lot of variables that go into how much radiation exposure you have on a certain distance. It also goes into your accident analysis as to how aggressive you need to be in your planning for accidents. And, also what kind of projections you need to include in your building your structures, your systems that you put in place in order to protect you from those potential worst case scenarios that can come up.

Isn't there a minimum NRC requirement, that says for example, here at your facility you've got a perimeter fence and you may even have another fence around this perimeter fence, but isn't there an NRC requirement that says if you, let's assume that you have somebody that has nothing better to do with his or her life than camp out at that perimeter fence 365 days a year. Thu NRC assumes then that individual will receive no more than $X$ radiation and you have got to build your facility to that hypothetical instance that somebody is camping out at your perineter fence and I think if what I recall year. telling me I think that dose is 25 milograms per

off the top of my head the number that comes to mind is 500 
milogram per year. Now there are other controls that you are going to want to put in place yourself but there are also other controls that regulation puts on you. How close a person can actually reside to an area that in effect gets that dose right now of 500 milogram per year. But, .....

Okay, I gotta take a report back to the Ponca tribe and one of the questions that is often asked aside all the safety and everytining is the payroll. You know the employees, how many jobs it's going to provide, what's the annual payroll on these plants? what is the numbers here for this plant annually, just a ball-park figure?

Again, I will have to talk off the top of my head, and I think I will be fairly accurate, but don't quote me on this. To give jou an idea, our security staff is 4 individuals at all times, so we have a rotating shift schedule where 1 it is always manned with 4 individuals. We have a designated radiation safety officer, who is the management official overseeing the radiation health effects on the facility. We have a maintenance manager who does the same thing for the O\&M of the facility.

What's that?

The operation and maintenance of the facility. Now, we don't have anybody specifically assigned full-time to the operation of the onsite storage facility, except for the securicy individuals. okay, that's our situation. 

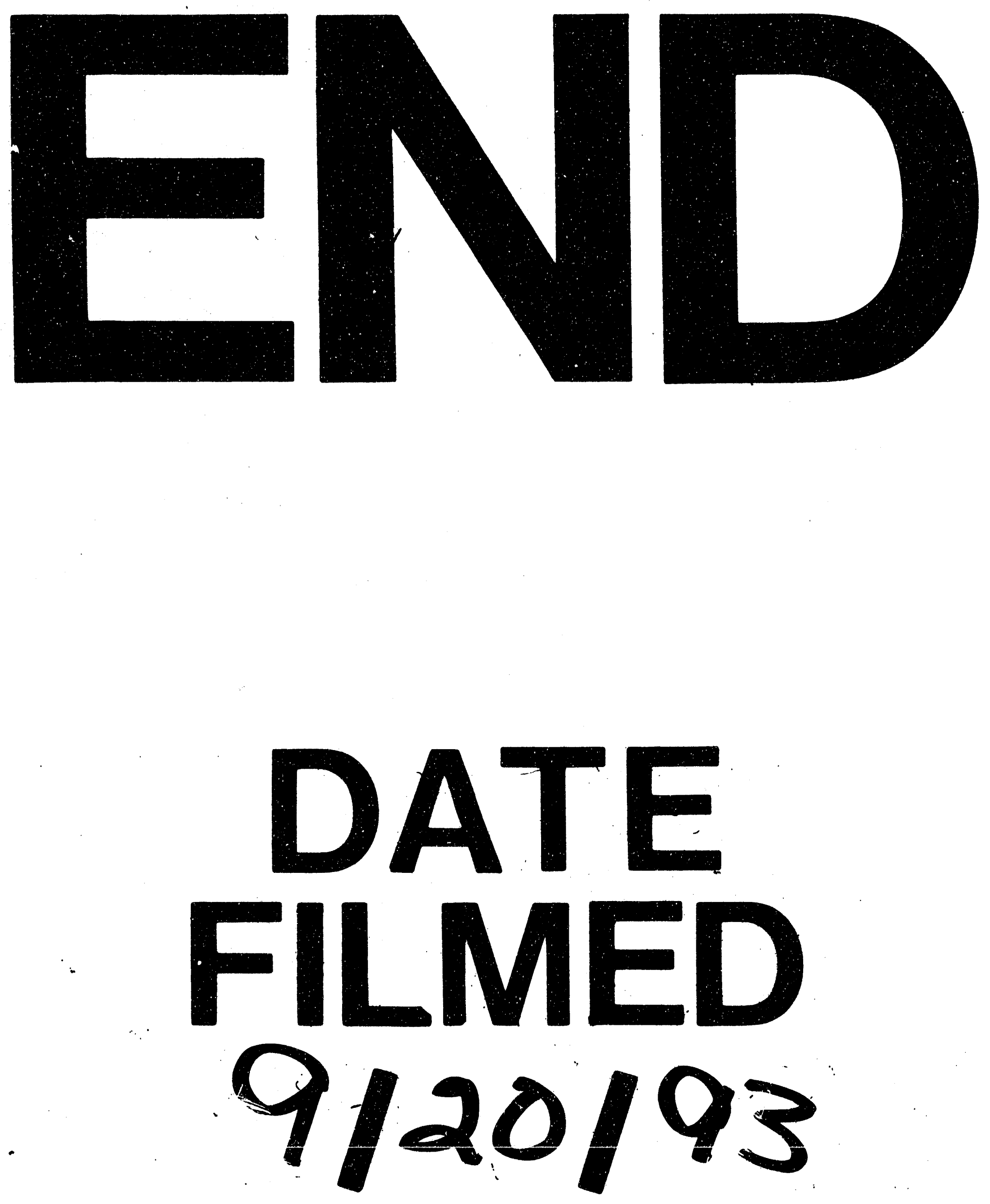
